UNIVERSIDADE DE SÃO PAULO

ESCOLA DE COMUNICAÇÕES E ARTES

DEPARTAMENTO DE ARTES CÊNICAS

PAULA BELLAGUARDA SEPULVIDA

Corinthians, Meu amor. Segundo Brava Companhia:

Teatro e militância na periferia da cidade de São Paulo

Versão Corrigida

São Paulo

2017 
PAULA BELLAGUARDA SEPULVIDA

\section{Corinthians, Meu amor. Segundo Brava Companhia: \\ Teatro e militância na periferia da cidade de São Paulo}

Versão Corrigida

Dissertação de Mestrado apresentada ao Programa de Pós-Graduação em Artes Cênicas da Escola de Comunicações e Artes da Universidade de São Paulo, como parte dos requisitos para obtenção do título de Mestre em Artes Cênicas.

Área de Concentração: Teoria e Prática do Teatro

Orientadora: Profa. Dra. Maria Silvia Betti

São Paulo 
Autorizo a reprodução e divulgação total ou parcial deste trabalho, por qualquer meio convencional ou eletrônico, para fins de estudo e pesquisa, desde que citada a fonte.

Catalogação na Publicação

Serviço de Biblioteca e Documentação

Escola de Comunicações e Artes da Universidade de São Paulo Dados fornecidos pelo(a) autor(a)

Sepulvida, Paula Bellaguarda de Castro

Corinthians, Meu amor. Segundo Brava Companhia: Teatro e militância na periferia da cidade de São Paulo. / Paula Bellaguarda de Castro Sepulvida. -- São Paulo: P. B. C. Sepulvida, 2017.

$$
213 \mathrm{p} \text {. }
$$

Dissertação (Mestrado) - Programa de Pós-Graduação em Artes Cênicas - Escola de Comunicações e Artes / Universidade de São Paulo.

Orientador: Profa. Dra. Maria Silvia Betti

Bibliografia

1. Teatro de grupo 2. Teatro Épico 3. Teatro Popular I. Betti, Profa. Dra. Maria Silvia II. Título.

CDD 21.ed. - 792 
SEPULVIDA, Paula Bellaguarda. Corinthians, Meu amor. Segundo Brava Companhia: Teatro e militância na periferia da cidade de São Paulo. Dissertação apresentada à Escola de Comunicação e Artes da Universidade de São Paulo para obtenção do título de Mestre em Artes Cênicas.

Aprovado em:

Banca examinadora

Prof. Dr.: Instituição:

Julgamento: Assinatura:

Prof. Dr.: Instituição:

Julgamento: Assinatura:

Prof. Dr.: Instituição:

Julgamento: Assinatura: 
Dedico este trabalho a Benjamin,

$$
\text { e a Lelê, }
$$

que me lembram que resistir é preciso.

E que o futuro...

vem. 


\section{Agradecimentos}

À Universidade de São Paulo e aos seus funcionários e professores responsáveis pela minha formação acadêmica.

Ao Núcleo Pele, do Cantinho do Céu, por me fazer ver os limites da minha formação acadêmica.

A todos os coletivos teatrais que marcaram minha trajetória e que formaram minha noção de arte pública, cheia de contradições: Cia Estável, Cia. São Jorge de Variedades, Teatro da Vertigem, Companhia do Latão. Ao Teatro de Ruínas, Teatro Vire(a) Lata, Arrinconamela, Jogos do Olhar, Coletivo Monumental, Grupo de Teatro da UMES, artistas com quem criei e que me criaram.

Ao Teatro Popular União e Olho Vivo, à Brava Companhia, ao Madeirite Rosa e à Trupe Lona Preta, por jogarem juntos nesse embate e por seguirem fazendo teatro e militância.

Agradeço especialmente ao integrantes da Brava Companhia, Fabio Resende, Rafaela Carneiro, Maxwell Raimundo, Cris Lima, Sergio Carozzi, Luciana Gabriel, Marcio Rodrigues, Henrique Alonso, Joel Carozzi, Ademir de Almeida, Kátia Alves e Débora Torres que embora não tenham sido formalmente entrevistados, estiveram presentes ao longo de toda a pesquisa, compartilhando reflexões e práticas sobre teatro e militância em espaços que se cruzaram pela vida.

Aos trabalhadores e trabalhadoras das Fábricas de Cultura da Poiesis pela greve que construímos, e que me fez acreditar, mais uma vez, na associação entre arte e militância. Agradeço também aos aprendizes, pela luta.

Agradeço a todos os autores, os vivos e os mortos, que dedicaram parte da sua vida para registrar aquilo que passava pelas suas mentes. Agradeço também a um bêbado, anônimo, que em uma conversa de boteco me narrou sua primeira experiência teatral, como espectador de uma peça do grupo Teatro Popular União e Olho Vivo.

Agradeço, principalmente, à professora orientadora Maria Silvia Betti, pela confiança e pelo estímulo à reflexão. Por me ensinar o prazer da pesquisa através da sua inquietação, ética e da seriedade com que conduz o seu trabalho, não apenas junto à 
Universidade de São Paulo, como professora e orientadora, mas também pela sua atuação militante.

Aos professores Sérgio de Carvalho e Anderson Gonçalves pelas considerações feitas no exame de qualificação que foram fundamentais para a continuidade dessa pesquisa, ainda que eu saiba que não dei conta do recado.

Às professoras Cibele Forjaz e Silvia Fernandes e ao Professor José Miguel Wisnik pelas aulas ministradas no programa de pós-graduação, determinantes para a construção do meu pensamento crítico e para a realização dessa pesquisa.

À Professora Ivone Daré - pelo estímulo e pelos retornos sempre muito atentos ao longo de toda a pesquisa - e ao Professor Edu Otsuka pelas aulas ministradas no programa de pós-graduação e pela possibilidade de dar continuidade à investigação que se iniciou nessas aulas no grupo "Formas Culturais e Sociais Contemporâneas." Ao Professor Anderson Gonçalves, mais uma vez, desta vez, principalmente pela parceria e pela contribuição direta no meu primeiro ensaio acadêmico, incorporado em partes nesta dissertação.

Aos demais participantes do grupo de estudos que contribuíram e contribuem diretamente com a minha reflexão diária sobre como as obras de arte estão representando o nosso mundo. Agradeço a confiança e a parceria na construção coletiva do conhecimento.

À Dany Maciel por ser completamente apaixonada e envolvida com o valor coletivo das práticas políticas e por compartilhar comigo a crise do trabalho com arteeducação. Ao Taiguara, por me lembrar da potência que é o teatro, na sua feitura em ato, e compartilhar comigo a crise do teatro no mundo dos editais. À dupla dinâmica, pela militância. Valeu! Foram experiências determinantes pra essa pesquisa.

Ao Márcio Castro, por ter se tornado um grande amigo com quem compartilhei materiais, sonhos e inquietações sobre teatro e militância.

À Letícia, por me lembrar da importância desta pesquisa e por me mandar mensagens carinhosas e sonhadoras.

À Mônica, pelo cuidado, e aos demais parceiros de Eutonia.

Aos amigos Sara Neiva, Fernanda Donnabela, Nina, Lilli Psique, Leandro, Tom, Gabi, Cronópio, Presto, Paulo Bio, Roberta Carbone, Carol Catini, Luis Pimentel, pela participação decisiva em momentos diferentes da pesquisa. Às vezes com uma 
colocação ou uma pergunta, um texto indicado, uma ideia que apareceu em uma conversa, aqui não tem autoria. À Marina e à Natacha, por serem "amor da cabeça aos pés", ao Danilo; A Caren e Dida, por me alimentarem quando eu esqueceria de comer; A Simone e Fabiana Carneiro, pela referência: pela noite mágica sob o céu de São Paulo e por serem pesquisadoras muito determinadas. A Liz, pela arte, pelo corpo e pela militância, sem hierarquias, em todas as áreas da vida; A Carolina Teixeira, por ocupar a periferia, o centro, o Butantã, a América Latina, o mundo com nosso útero; A Maíra, por ser a mulher mais engajada com a causa feminista que eu conheci; A Carol Vecchia, por ser a única pessoa capaz de permanecer junto comigo em um debate continuado de ideias, profundas, loucas, insanas, mas profundamente serias, durante 18 horas, sem parar; A Renatinha, por sentar ao meu lado em silêncio e fazer mais sentido que mil palavras; A Marijones, pelo brilho no olhar; Ao Cesar, à Fezinha, ao Acauam e ao Breno, pelos voos de pensamento que ultrapassam todos os limites... a Fabito e Jubileu, pela atuação artística que movimentou minhas reflexões, a Tânia, por cutucar vespeiros, a Bia, por ser uma base, uma sustentação, o colo e a cutucada necessária me lembrando que às vezes as coisas são mais simples; Ao Daniel Manzione, pelas conversas sobre a zona sul, e por me acompanhar em campo por lá; a Gabriel, pelas experiências de militância que compartilhou comigo, a Anita e a Teresa, por se embrenharem na academia mesmo pertencendo à vida e tecendo, só por isso, fios que as vezes me faltam... a Sil... Ao Mathias Lisboa... agradeço, enfim a toda a Gazeta do Butantã - desculpa galera, somos muitos, um clã enorme que sustenta meus mais altos vôos em direção ao impossível, pontuo aqui apenas aqueles que contribuíram diretamente com a pesquisa, - mas sem cada um de vocês nenhuma letrinha sairia pelos meus dedos....

A José Virgínio, que fez parte de cada movimento reflexivo dessa dissertação, e que foi uma espécie de co-pesquisador desse trabalho. Que acompanhou todas as inquietações, esteve a par de todos os movimentos, indicou leituras, debateu os textos, as peças, povoou a minha vida de livros e autores que eu desconhecia, e me ensinou o prazer da análise estética. Agradeço também por ter sido você quem "descobriu" o ponto de vista da peça, afinal de contas o Olho Vivo é teu.

A Carol Zu e Patrícia Kruger: Bruxas mágicas que me ajudaram a colocar no mundo essa dissertação. Que cuidaram de mim e da minha pesquisa em tempos mais do 
que difíceis; que sinto a presença e a participação na minha vida mesmo quando não estão por perto. Que agem em mim pois não param, nunca, de agir sobre o mundo.

Agradeço a meu pai, por filosofar comigo desde a infância, minha irmã Mariana por me fazer as perguntas certas, e minha mãe, por me incitar a agir, e por me ajudar a colocar no mundo esse trabalho, com a mesma rigidez e amor com que coloca pessoas no mundo.

Às minhas avós Roilme, por ser a flor mais linda do meu jardim, e Anna, por ser o livro mais misterioso.

Agradeço ao carnaval, por misturar essas experiências no meu corpo. 
Toda a vida social é essencialmente prática. Todos os mistérios que desviam a teoria para o misticismo encontram a sua solução racional na prática humana e na compreensão dessa prática.

(Karl Marx) 


\section{Resumo}

SEPUlVIDA, Paula Bellaguarda. Corinthians, Meu amor. Segundo Brava Companhia: Teatro e militância na periferia da cidade de São Paulo. 2017. Dissertação (Mestrado). Escola de Comunicação e Artes, Universidade de São Paulo, São Paulo. 2017.

Este trabalho realiza uma analise estética da encenação Corinthians Meu amor. Segundo Brava Companhia. Uma Homenagem ao Teatro Popular União e Olho Vivo, que tem como intuito compreender as influências do grupo homenageado e das movimentações políticas ocorridas ao longo da ditadura militar no Brasil, sobretudo nos anos 1970, sobre o trabalho da Brava Companhia.

A pesquisa, que tem por base a dramaturgia original de Cesar Vieira, escrita em 1966, compara a primeira ao texto cênico proposto pela Brava Companhia, em 2011.

Nosso objetivo foi tecer considerações e hipóteses acerca das transformações na cena teatral militante produzida junto às "classes populares" e aos trabalhadores ao longo dos últimos anos. Tendo como base a análise comparativa dos dois documentos dramatúrgicos, esta pesquisa buscou interpretar tais modificações estilísticas à luz de uma prática de teatro épico, bastante presente na cena teatral paulistana.

Palavras chave: teatro popular, teatro épico, teatro de grupo, Teatro Popular União e Olho Vivo, Brava Companhia 


\begin{abstract}
SEPULVIDA, Paula Bellaguarda. Corinthians, My love. According to Brava Company: Theater and militancy in the periphery of the city of São Paulo. 2017. Dissertação (Mestrado). Escola de Comunicação e Artes, Universidade de São Paulo, São Paulo. 2017.
\end{abstract}

Corinthians, My love. According to Brava Company: Theater and militancy in the periphery of the city of São Paulo performs an aesthetic analysis of the play Corinthians, Meu Amor. Segundo Brava Companhia. Uma homenagem ao Teatro Popular União e Olho Vivo (Corinthians, My love. According to Brava Company. A tribute to the group Teatro Popular União e Olho Vivo (TUOV)) which aims to understand the influences of the honored group and the political movements that took place during the military dictatorship in Brazil, especially in the 1970s, on the work of the Brava Company.

The research, based on the o riginal dramaturgy written by Cesar Vieira, in 1966, compares the original text to the staging proposed by Brava in 2011. Our intention was to weave considerations and hypotheses about the transformations in the militant theatrical scene produced close to the "popular classes" and the worker class, over the last years. Based on the comparative analysis of the two dramaturgical documents, the research sought to interpret such stylistic changes in the practices of an epic theater based in Brecht's work, due to its great importance in the theatrical scene in São Paulo.

Keywords: Popular Theater, epic theater, group theater, Teatro Popular União e Olho Vivo, Brava Companhia. 


\section{Sumário}

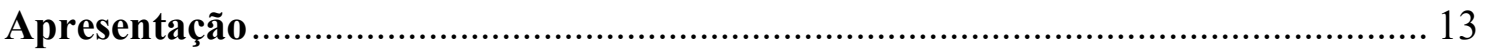

1. Teatro Popular União e Olho Vivo - um fio vermelho que costura a história ... 28

2. Tradição crítica e o valor coletivo do trabalho teatral ........................................ 49

2.1 O ponto de vista do Olho Vivo - a ação histórica do Coringa ........................... 52

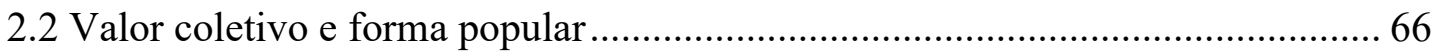

2.3 Mobilização coletiva e a coralidade do público...................................................... 75

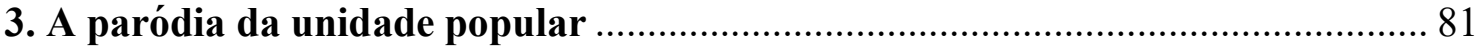

4. O Gestus do trabalhador sem identidade de classes - trabalhador sem classe e

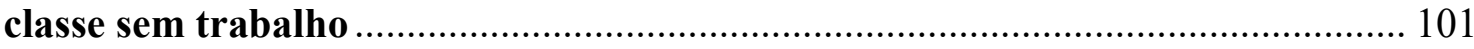

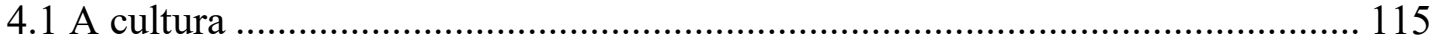

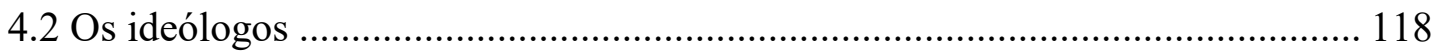

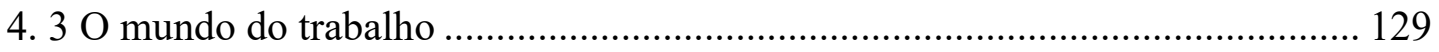

5. Do épico à peça de aprendizagem - um problema de representação …............. 142

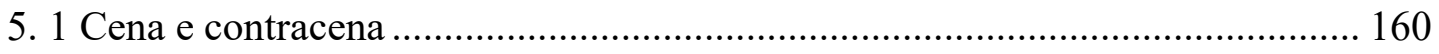

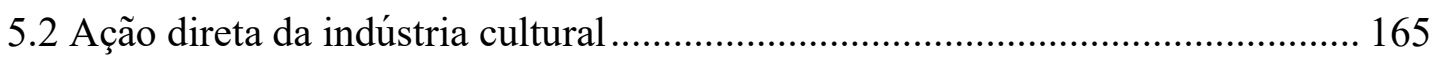

5. 3 A batalha final - um por todos ou todos por um? ....................................... 176

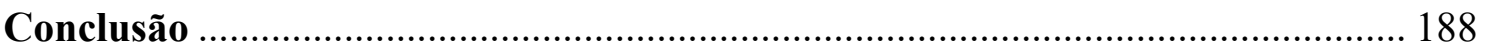

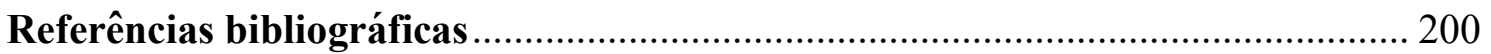

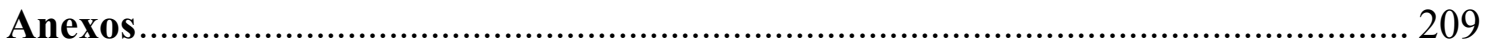

Anexo A - Ficha técnica: Corinthians, Meu amor - a Revolução Alvi-Negra ....... 209

Anexo B - Ficha técnica: Corinthians, meu amor. Segundo Brava Companhia .... 210 


\section{Apresentação}

Os reacionários procuram sempre, a qualquer pretexto, dividir a esquerda. A luta que deve ser conduzida contra eles é, às vezes, por eles conduzida no seio da própria esquerda. Por isso, nós - festivos, sérios ou sisudos - devemos nos precaver. Nós que, em diferentes graus, desejamos modificações radicais na arte e na sociedade, devemos evitar que diferenças táticas de cada grupo artístico se transformem numa estratégia global suicida. O que os reacionários desejam é ver a esquerda transformada em saco de gatos; desejam que a esquerda se derrote a si mesma. Contra isso devemos todos reagir: temos o dever de impedi-lo. Porém, a pretexto de não dividir, não temos também o direito de calar nossas divergências. Pelo contrário: as diferentes tendências da nossa arte atual serão melhor entendidas através do cotejo de metas e processos. Isto é necessário,

principalmente neste momento em que toda a arte de esquerda enfrenta a necessidade de colocar os seus processos e as suas metas. O choque entre as diversas tendências não deve significar a predominância final de nenhuma, já que todas devem ser superadas, pois foram também superadas as circunstâncias políticas que as determinaram, cada uma no seu momento.

(Augusto Boal)

Ao adentrar um galpão ocupado por diversos coletivos artísticos da periferia da cidade de São Paulo e assistir a um espetáculo teatral ali criado e representado, as questões que se colocam para a análise transcendem a relação direta entre espectador e obra teatral. São lançadas pelo objeto perguntas de ordem sociológica e literária, urbanísticas e históricas que nos impedem de transformar em uma tarefa de gosto a análise dos processos de mediação dessa obra. Ao mesmo tempo, a dificuldade para decifrar certos movimentos de cena que apresentam aparente precariedade formal nos coloca em dúvida também sobre os instrumentos de análise aos quais devemos ou podemos recorrer para dar conta dessa importante tarefa.

A localização, a história do local, a paisagem que atravessamos para acessar o local, o tipo de financiamento, a gestão e a programação do espaço, suas condições de produção e reprodução dentro das esferas políticas e culturais, tudo conta para que possamos nos aproximar da obra. Cada lance de olhar nos sugere questões novas. Aparentemente, o papel delegado à produção cultural colocou em outro lugar as relações que dela emanavam. Se a importância dada ao objeto artístico chegou a ser fundamental para a consolidação de uma unidade nacional no país e para a organização do discurso da formação, e se o teatro chegou a ser radicalmente vinculado a um projeto 
de nação igualitário, hoje em dia, sob os efeitos do neoliberalismo, a instituição artística mostra-se, sobremaneira, como mais um campo em disputa, no qual convivem, contraditoriamente, as forças do Capital e as forças de resistência a ele.

Nesse contexto, o lugar destinado às artes públicas alterou-se substancialmente, e não apenas a forma do público e as relações que emanam do encontro entre artistas, obra (quando ainda podemos chamar certos trabalhos de obras) e público passaram a ser objeto de análise formal, como também os modos de produção adotados para que a obra se colocasse no mundo começaram a ser de primeira ordem na interpretação de seus resultados estéticos. Não se trata, contudo, de uma novidade no campo das artes se pensarmos que, em outros momentos de crise do Capital, essa barreira já fora tensionada:

\footnotetext{
Se voltarmos agora o olhar ao processo de fusão das formas literárias mencionado no início, veremos como a fotografia, a música e outros elementos, que não conhecemos ainda, mergulham naquela massa liquida incandescente da qual serão cunhadas novas formas. Confirma-se, assim, que é somente a literarização de todas as relações vitais que permite dar uma ideia exata do alcance desse processo de fusão, do mesmo modo que é o nível da luta de classes que determina a temperatura na qual se dá a fusão, de modo mais ou menos completo (BENJAMIN, 2012, p.140).
}

Trata-se, todavia, de um novo momento do Capital, em que, diferentemente de outrora, o horizonte de expectativas (revolucionárias) se encurtou e alguns conceitos clássicos do marxismo, tais como proletariado ou trabalhador, parecem não mais contribuir para uma efetiva consciência acerca da luta de classes, ainda que a dimensão cultural, ou seja, a literarização de praticamente todas as relações sociais, pareça ter emergido dos avanços da técnica.

Como compreender esse processo histórico à luz de um objeto artístico? $\mathrm{Ou}$ melhor, como um objeto artístico pode nos revelar esse processo sem abandonar, por sua vez, o tecido social que o alinhava com o momento anterior? No contexto brasileiro, devido ao golpe militar em 1964, alguns fios permanecem desatados pela força da ruptura democrática e pela violência repressiva. Por outro lado, a força da resistência cultural no período conseguiu sobreviver (o que não é pouco!) produzindo em meio à ditadura o que Roberto Schwarz, no importante artigo "Cultura e política, 1964-1969", qualifica como "uma relativa hegemonia cultural de esquerda" (SCHWARZ, 2008, p.71). Mais do que isso, a força dessa resistência nos traz indícios de como esses laços 
podem ser atados e nos fornece ferramentas para que possamos observar o tempo presente e sua produção cultural como parte de um processo com bases anteriores ao próprio golpe de 1964, ainda que tal força apresente-se não como avanço, mas como reflexo precário com inspiração em lutas passadas.

É buscando levar em conta esse amplo aporte de variáveis que pretendemos nos ater à tarefa de analisar o espetáculo Corinthians, meu amor - segundo Brava Companhia - Uma homenagem ao Teatro Popular União e Olho Vivo. Criado em 2011, no Parque Santo Antônio, zona sul de São Paulo, pelo coletivo teatral Brava Companhia, a peça baseia-se no texto Corinthians, meu amor, escrito em 1966 por César Vieira, diretor e dramaturgo do grupo homenageado. O texto original, escrito antes mesmo que o grupo Teatro Popular União e Olho Vivo fosse oficialmente criado, foi publicado com o intuito de ser um pré-roteiro cinematográfico e circulou, em uma revista, pelas bancas da cidade. O material transformou-se em teatro devido ao interesse dos atores do chamado Teatro Casarão (formado por trabalhadores de diferentes áreas), que entraram em contato com o autor pedindo uma adaptação do original que pudesse ser posta em cena pelo grupo amador. A peça trata da vida de diversos personagens, também trabalhadores e trabalhadoras da cidade de São Paulo, que se veem unidos por uma mesma paixão pelo time do Corinthians, o time do povo.

A partir desse mesmo motivo, e tendo como ponto de partida o texto original, Fábio Resende, o responsável pela dramaturgia na nova montagem, reescreve o texto fazendo jus às expectativas do autor César Vieira, que, no livro Em busca de um teatro popular, defende que o seu texto é "aberto e sempre foi colocado como motivação para um espetáculo popular" (VIEIRA, 2007, p. 87), o que o levou a fazer um convite à Brava Companhia para que a peça fosse recriada como parte das comemorações do centenário do time.

Com isso, alguns dos deslocamentos conceituais friccionados pela peça original são especialmente explorados na versão da Brava. Trata-se, como alertamos anteriormente, das diferentes inflexões da ideia de popular, que, no vocabulário do marxismo clássico, caminha ao lado da classe proletária, mas que parece ter perdido seus contornos claros no contexto neoliberal e de novas formas de exploração. Com direção de Rafaela Carneiro, e com um elenco de jogadores profundamente envolvidos com a militância na região formado por Ademir de Almeida, Cris Lima, Debora Torres, 
Henrique Alonso, Joel Carozzi, Luciana Gabriel, Márcio Rodrigues, Max Raimundo e Sergio Carozzi, a peça parece se debruçar sobre questões extremamente atuais, embora contribua para evidenciar a historicidade dos problemas representados. Tomam-se, diante disso, novas formas, mais atentas às representações da pobreza do que, precisamente, do conflito de classes, enquanto este, por sua vez, não desaparece, seja das representações, seja do campo social.

Sendo assim, como e o quê interessou à Brava Companhia no diálogo com a peça de César Vieira? Que formas o grupo encontrou para representar a distância temporal que o separa do grupo homenageado, sem que se tratasse de um elogio, mas de uma recriação, visto que a peça reposiciona as mesmas questões colocadas pelo grupo precedente, mas à luz de seu próprio momento histórico?

A opção desta pesquisa por tomar como documentos a serem analisados apenas os materiais publicados pelos próprios grupos, sem recorrer a entrevistas ou documentos pessoais pertencentes aos acervos dos autores analisados, dá-se pelo interesse de conjugar os trabalhos em uma dimensão pública, atentando, sobretudo, à forma como os grupos escolhem veicular suas trajetórias artísticas e políticas, o que já implica a dimensão politica dos próprios trabalhos.

Atentas a isso, as duas companhias realizaram publicações de suas dramaturgias e dos escritos teóricos que fundamentam nossa análise, tendo os materiais sido redigidos por integrantes das companhias, expressando parte das pesquisas em curso dentro dos coletivos. Somaram-se a esse material análises críticas e estéticas acerca do período, que nos possibilitaram interpretar, à luz de outros elementos, as inflexões do processo histórico sobre os trabalhos de ambos. Nesse sentido, nossa contribuição visa apenas a coordenar hipóteses acerca de uma possibilidade interpretativa relacionada à produção cultural com expectativas militantes. As opções estéticas, éticas e políticas dos grupos analisados corresponderiam, portanto, a esse enunciado e procurariam apreender da realidade social as possibilidades de conjunção dessas premissas.

A Brava Companhia, ponto de vista de onde partimos para este estudo, foi formada em 1998. O grupo, inicialmente chamado ManiCômicos, buscou, desde a sua formação, uma perspectiva democrática e uma ação sistemática na periferia, atuando junto a escolas, organizações de bairro, praças e centros comunitários com atividades que iam desde apresentações até oficinas, sempre estimulados pelo forte envolvimento 
do público em suas práticas. Dessas oficinas, em meados de 2005 surgiu o projeto Arte por Toda Parte que, devido ao grande sucesso, rumou para São João del-Rei, em Minas Gerais, dando início a uma nova etapa do trabalho da companhia, que acabou se dividindo.

Formados no bojo do crescimento da atuação de ONGs nas regiões periféricas, mas se opondo à mercantilização e gestão da pobreza que ocorria com tal processo, alguns dos integrantes do ManiCômicos permaneceram em São Paulo. Movidos pelo desejo de atuar politicamente criaram, em 2005, o espetáculo A Brava, que dá nome à companhia e que permanece em seu repertório até os dias de hoje. Em 2007, a convite de outros coletivos da região, o grupo ocupa o Sacolão das Artes, um amplo espaço que fora um mercado hortifrúti e que passa a acolher grupos culturais, propondo uma programação diversificada e pensada coletivamente pelo coletivo gestor. Até 2016, o espaço permaneceu sendo a sede da companhia, onde, de maneira autogestionada, a Brava aprofundou seus direcionamentos críticos, estéticos e políticos, contribuindo com a programação e com a gestão no intuito de consolidar um espaço agregador de lazer, reflexão e lutas políticas. Dadas as sequenciais investidas do poder público para inviabilizar as atividades do espaço, somadas a divergências internas ao coletivo gestor, a companhia decide encerrar suas atividades no espaço na busca de novos caminhos para a continuidade de seus trabalhos:

Mudam-se os tempos, nascem novas necessidades: a criação do Coletivo
Gestor impulsionou o funcionamento do espaço, pautado por uma
organização que dividiu os integrantes em grupos de trabalho (G.T.)
responsáveis pelas diversas áreas abrangidas pelas ações do Sacolão das
Artes, dentre as quais se destacam: divulgação, manutenção do espaço e
captação de recursos, desdobrando-se esta última, resultado do trabalho de
seus componentes, na premiação Cultura Viva. No entanto, esse novo
formato de organização começou a definhar por causa de pressões externas e
internas que diluíram os GTs. Apresentava-se uma nova crise de organização.
Contudo, os integrantes do coletivo gestor buscaram diversas formas de
manter vivo o espaço cujo caráter é e sempre foi o de construção de
pensamento crítico (BRAVA, 2014, p.71-72).

A companhia reconhece o cerne de sua formação na experiência dos grupos teatrais que atuavam, durante a ditadura, de forma militante nas periferias da cidade. No seminário Teatro e Sociedade, realizado em 2014 pela Companhia do Latão na Oficina Cultural Oswald de Andrade, o integrante Maxwell Raimundo apontava que os grupos de mães do bairro e os grupos ligados ao sindicato e à igreja semearam o trabalho 
desenvolvido por eles no Sacolão. Essa narrativa é reforçada em um artigo de autoria do mesmo integrante e publicado no Caderno de erros III da Brava Companhia (BRAVA, 2014). No artigo "Pequeno histórico do Sacolão das Artes", acompanhamos tanto uma narrativa sobre o processo de organização política da região, quanto os reflexos dessa história de lutas dos moradores do bairro nas tentativas de organização e gestão do Sacolão das Artes e na investigação de novas formas:

\begin{abstract}
Essas formas [divisão em GTs mencionada na nota anterior] interferiram diretamente na organização do Coletivo Gestor, que passou a abrigar outra reunião além da sua própria: esta com a comunidade, que chegou a registrar presença de 50 moradores do bairro discutindo e refletindo sobre os problemas que os atingiam cotidianamente. As pautas, como visto anteriormente, eram a canalização do Córrego Freitas, a criação de um semáforo na av. Cândido José Xavier, a mudança do ponto de ônibus da linha São Judas, resolução do problema com lixo por meio da cooperativa de catadores (Coopergaia) e criação de uma UBS que atendesse a outra parte do bairro (BRAVA, 2014, p. 72).
\end{abstract}

Como descreve Eder Sader em Quando novos personagens entram em cena (SADER, 1988), essa forma de engajamento político-social subscreve-se na história de lutas por direitos desde os anos de 1970 e teve forte inserção nas periferias da cidade de São Paulo como um contraponto à ditadura protagonizado pela "sociedade civill, ainda que representando um quadro bastante diversificado de atuação.

Tendo isso em vista, a experiência do Teatro Popular União e Olho Vivo, grupo homenageado pela peça Corinthians, meu amor - segundo Brava Companhia (2011), não apenas é reflexo de relações éticas e estéticas sustentadas pelos grupos, e de um quadro de influências artísticas que lhes é comum, como também se relaciona diretamente com o processo subscrito na história de ambos os grupos - pautado pela ação junto às comunidades periféricas -, ainda que não tenha havido um contato efetivo e direto entre os integrantes dos dois coletivos teatrais.

Essa atuação política insere-se em um espectro mais amplo de mobilização cultural, que remonta aos diversos grupos teatrais com características militantes, muito atuantes na resistência à ditadura durante os anos 1970, conforme descreve Silvana Garcia em seu estudo O teatro da militância (GARCIA, 1990). Esses coletivos teatrais da década de 1970, embora compondo um quadro extremamente diversificado de atuação estética e política e inviabilizando a hipótese de que houvesse ali um movimento cultural organizado, focaram suas práticas nas regiões periféricas e no contato direto com as comunidades. Mais especificamente, os coletivos artísticos 
contribuíam e somavam-se aos novos grupos de esquerda em uma configuração constituída, basicamente, da "articulação da esquerda católica, movimentos sociais basistas e militantes laicos antinacionalistas", que voltaram sua ação para o trabalho de base junto aos bairros periféricos.

Essa nova configuração da organização política, que despontou ao longo da década de 1970, parece ter sido central, seja como resistência contra a ditadura, seja como início de uma articulação de pautas que seria determinante para os avanços democráticos alcançados a partir da década seguinte, como nos faz notar Eder Sader (1988). Também na área cultural, embora com proporções menos visíveis, as novas formas de organização da esquerda deixaram marcas profundas na estética via incorporação de temas e formas ligadas ao escopo da cultura popular, como ressalta Silvana Garcia (1990), e, sobretudo, no que se refere às formas de produção e criação, conforme é possível apreender na livre docência de Marcos Napolitano Coração civil: arte, resistência e lutas culturais durante o regime militar brasileiro (1964-1980). (NAPOLITANO, 2011) Esse trabalho, que busca abordar, principalmente, o debate acerca dos processos culturais no período, nos serve como base para a compreensão dos movimentos ideológicos e tensões estéticas e políticas que separam o texto original de César Vieira da versão concebida pela Brava Companhia.

Dessa maneira, o que procuraremos averiguar com esta pesquisa é, primordialmente, em que medida e de que forma as práticas culturais dos grupos de teatro vinculados à militância dos anos 1970 se arraigaram nas propostas artísticas da Brava Companhia. Partimos, para tanto, do pressuposto de que, embora de maneira subreptícia, as proposições estéticas, as práticas artísticas, os temas e as questões abordadas por esse teatro militante encampado por grupos como o TUOV parecem ter sobrevivido à abertura neoliberal por meio de uma "rede de recados" que atravessou todo o período ditatorial ao ser "sussurrada" por alguns sujeitos históricos.

O trabalho do TUOV, nessa perspectiva, aparece como imprescindível para que possamos apreender algumas dessas nuances, haja vista que sua atividade culturalmilitante atravessou todo o período e segue em curso, caracterizando-o como um dos mais antigos grupos teatrais em atividade continua na América Latina. A ação do diretor e dramaturgo César Vieira (Idibal Piveta) ultrapassou a esfera cultural, inscrevendo-se em alguns processos centrais para a organização político-cultural da cidade e, mesmo 
depois da ditadura, seu envolvimento na fundação da Cooperativa Paulista de Teatro (1979) e junto ao movimento "Arte contra a Barbárie", movimentação política que levou à criação da Lei Municipal de Fomento ao Teatro (2002), foi essencial para a articulação de algumas ideias centrais no debate estético da cidade de São Paulo.

Essa atuação, ainda que não vivenciada em papéis de protagonismo dentro dos mencionados processos, confere ao grupo uma importância de primeira ordem no que se refere à memória do período. Principalmente por manter-se à margem da indústria cultural e persistir atuando de maneira militante desde a sua fundação, o grupo se implicou de maneira radical na tarefa de permanecer ao lado da classe trabalhadora, registrando, em sua trajetória, diferentes formas tomadas pelo debate de classes no Brasil, que é atravessado, sistematicamente, por novos conceitos, capazes tanto de capturar as transformações no corpo social, quanto de mascarar suas contradições.

Desde a importância dada aos processos pedagógicos e de partilha, até os esforços de horizontalidade dentro dos trabalhos criativos, a opção programática de acessar um "público popular" composto por trabalhadores e trabalhadoras sugere uma enorme conexão entre as proposições feitas pelo TUOV e as de outros coletivos artísticos que desenvolvem trabalhos culturais vinculados à militância política nas periferias, dentre eles a Brava Companhia. O objetivo central de tais opções é o de fundir objeto artístico e processo produtivo para uma conscientização acerca dos lugares de classe operados pela cultura a fim de garantir uma apropriação da ideia de sujeitos históricos por parte da classe trabalhadora.

Nesse sentido, sobretudo no que se refere aos avanços na esfera de produção e reprodução da cultura e na criação de políticas que viabilizem um teatro independente ${ }^{2}$,

\footnotetext{
1 O movimento "Arte contra a Barbárie" teve início em 1998 e, além do sucesso alcançado com a promulgação da lei, articulou os grupos da cidade em torno de demais atividades e debates sobre estética e política na cidade de São Paulo. Nas palavras de Piacentini, "Talvez um dos maiores progressos do movimento Arte contra a Barbárie, que derivou na Lei de Fomento, tenha sido a promoção do hábito do encontro entre os agentes teatrais de grupos e as companhias da cidade de São Paulo. Se no início tivemos as reuniões em torno do movimento, depois lançamos os debates públicos com as comissões julgadoras e, num outro momento, veio o 'espaço da cena' para discutir os rumos da própria lei e promover o diálogo entre os coletivos, convocando também à reflexão os pensadores da nossa situação política, social, econômica e cultural" (PIACENTINI, 2012, p. 13).

${ }^{2}$ Caracterizamos aqui o teatro independente como grupos ativos na cidade de São Paulo, sobretudo nas década de 1980/1990, que desenvolveram pesquisa de linguagem e dramaturgia autoral sem o apoio ou o finaciamento do Estado. Os grupos de teatro independente foram também os responsáveis pela formação da Cooperativa Paulista de Teatro em 1979 e marcam uma importante etapa do trabalho teatral na cidade de São Paulo. Nesse sentido, a tese de Alexandre Mate é fundamental compreendermos a relevância de tais grupos e projetos artísticos (MATE, 2008).
} 
o marco histórico estabelecido pela promulgação da Lei de Fomento ao Teatro para a cidade de São Paulo e a compreensão de alguns dos antepassados desse movimento de grupos da cidade são centrais para capturarmos os deslocamentos ocorridos na cena, como sugere Iná Camargo Costa no ensaio "O teatro de grupo e alguns antepassados" (COSTA, 2011). A influência estética e política dos antecessores, embora não correspondendo a uma continuidade efetiva de suas práticas e, por vezes, não se dando de maneira programática, faz-se determinante para que possamos compreender a atual configuração da cena teatral, como expõe Costa:

Os limites estéticos e políticos do teatro naturalista em arena foram confrontados muito rapidamente, entre outros motivos, pela aceleração da nossa vida política e social: em pouco tempo surgiram propostas mais radicais, como as formas do teatro épico e as do agitprop do Centro Popular de Cultura CPC da UNE. Porém, mais rapidamente ainda, o Brasil conservador reagiu de armas na mão. A ditadura militar de 1964 impôs um claro limite às experimentações cênicas que estavam em andamento e, depois do incêndio da UNE, o teatro brasileiro entrou num compasso de espera no plano da experiência estética até hoje ainda não superado. Desde meados da década de 1990, como uma praga, mas em situação muito pior do que no início dos anos 1950, os pobres novamente começaram a se organizar em grupos para fazer teatro. Agora, em vez de um grupinho de ex-alunos da Escola de Arte Dramática (EAD), temos inúmeros grupos, até porque proliferaram as escolas de teatro. E, em sua maioria, para não arriscar a dizer na totalidade, enfrentam do ponto de vista prático (situação econômica), organizacional e estético problemas muito semelhantes aos que o Arena enfrentou ao longo de sua trajetória. Por isso podemos dizer que o Arena é nosso marco zero e que o CPC da UNE é o nosso limite. Em outras palavras, a grande maioria dos atuais grupos brasileiros de teatro enfrenta os problemas econômicos que o Arena enfrentou, sem conseguir encontrar uma resposta que lhes assegure um mínimo de estabilidade para dar prosseguimento a suas pesquisas, tanto no caso dos que dispõem de espaço quanto no caso dos que nem ao menos o conseguem; no âmbito das linguagens que desenvolvem, principalmente em decorrência dos conteúdos que lhes interessam, o solo em que pisam (principalmente no âmbito dramatúrgico) foi delimitado pelo naturalismo; e, finalmente, a organização em grupos estabelece uma experiência política (a do coletivo) que entre nós começou com o Arena. Entretanto, não se trata de repetir a história, nem mesmo de maneira farsesca; para complicar um pouco as coisas, desde meados dos anos 1950 o grupo do Arena entrou em acelerado processo de politização que culminou com a saída de Vianinha e Chico de Assis. Estes acabaram por participar da fundação do CPC por razões estéticas e políticas de tal modo entrelaçadas que não podem ser pensadas em separado. Pois bem: seja pela condição de gato escaldado, seja por falta de experiência política, não parece estar no horizonte dos nossos grupos nenhuma das questões que levaram aqueles dois artistas aos experimentos mais radicais do teatro brasileiro no século XX. (COSTA, 2011, p. 53)

Não podemos ignorar que artistas como Chico de Assis seguiram atuantes junto ao teatro independente, e, como bem descreve Alexandre Mate na sua tese $A$ produção 
teatral paulistana dos anos 1980: r(ab)iscando com faca o chão da história: tempo de contar os (pré) juízos em percurso de andança, ( MATE, 2008) embora não determinem a tônica do período são fundamentais para a sua compreensão.

Tomando parte no mesmo debate, Paulo Arantes parece propor novos apontamentos acerca dos avanços institucionalizados pela lei. Ainda em 2008, em uma entrevista concedida a Beth Néspoli e publicada no jornal O Estado de São Paulo, posteriormente reeditada no livro $O$ novo tempo do mundo, em 2014, o autor ressalta a potência da produção teatral da cidade, diferenciando substancialmente os trabalhos dos antecessores e os dos coletivos do atual movimento de teatro de grupo. Todavia, a pertinente menção às semelhanças entre ambos os movimentos também não pode ser ignorada, o que torna ainda mais evidente o rastro que buscamos perseguir:

\begin{abstract}
Ao lado da explosão do hip-hop, com o qual tem muito a ver malgrado as diferenças de escala e classe, não sou por certo o único a reconhecer no atual renascimento do teatro de grupo o fato cultural público mais significativo hoje em São Paulo. Fala-se de mais de 500 coletivos, por assim dizer, dando combate no front cultural que se abriu com a ofensiva privatizante. Não são só os números que impressionam, mas também a qualidade das encenações, cuja contundência surpreende, ainda mais quando associada a uma ocupação inédita de espaços os mais inesperados da cidade, gerando pelo menos o desenho de uma mistura social que ninguém planejou, simplesmente está acontecendo como efeito colateral das segregações e hierarquias que o novo estado do mundo vai multiplicando (ARANTES, 2014).
\end{abstract}

A ressalva, contudo, explicitada pelo autor no que se refere à presença do hiphop e sua composição de classes, não surge à toa, nem ignora a ruptura perpetrada pela ditadura entre os movimentos de trabalhadores organizados, as classes populares e a produção teatral dos grupos. O mesmo argumento nos dá a ver a multiplicação dos grupos também em áreas periféricas e a tentativa de romper a segregação social que se adensava. Não se pode ignorar que tal tentativa consiste em norte estético e político de grupos que, como o Teatro Popular União e Olho Vivo, atuaram de forma militante na periferia da cidade de São Paulo. Tendo isso em vista, a década de 1970 nos parece crucial para compreendermos o processo descrito por Arantes, que levaria a cidade a se tornar o novo palco das lutas sociais:

A vitalidade teatral dos anos 60 , à qual a Universidade respondeu à altura, era ascensional. Por paradoxal que possa parecer, a surpreendente vitalidade de agora se deve ao poder de revelação de um desastre nacional [...]. Por um momento de real esclarecimento das forças em confronto - descontada uma 


\begin{abstract}
boa dose de fantasia política indispensável -, gente de teatro, professores e estudante, partidos operários e ebulição sindical formaram uma mesma frente única de ruptura possível. O resto se sabe. Uma ditadura depois, seguida de uma Abertura decepcionante [...]. A Fábrica, fracionada pelas cadeias produtivas globais, saiu de cena, e com ela a consciência de classes de uma multidão de indivíduos entregues ao deus-dará de uma exploração para a qual ainda não se tem nome. A engrenagem infernal dessa ciranda da viração me parece estar na origem de uma resposta coletiva como o teatro de grupo [...]. Também me parece claro que o novo chão de fábrica seja o próprio território conflagrado da cidade, daí a relação orgânica do teatro de grupo com o espaço urbano, vivido agora em regime de urgência (ARANTES, 2014).
\end{abstract}

Nesse sentido, para compreendermos esteticamente o deslocamento ocorrido, torna-se necessário pressupor uma tradição crítica comum, fundamentada em uma leitura materialista do processo histórico. As contribuições de Arantes e Iná Camargo Costa depreendem, embora diferenciando substancialmente as práticas, um chão comum pautado pela cena teatral pré-golpe, composta pelo Teatro de Arena e pelo CPC, como parâmetros indispensáveis à compreensão do atual movimento de teatro de grupo. A presença, nesse sentido, de pressupostos teatrais coletivistas e com fins militantes de engajamento político orienta as escolhas estéticas dos grupos, estimulando o debate em direção a perguntas levantadas pelo agitprop e por Bertolt Brecht.

Por meio da importante obra $O$ trabalho de Brecht, publicada por José Antonio Pasta em 1986 e reeditada em 2010 pela Editora 34, tivemos contato com uma nova perspectiva de compreensão do trabalho do autor, que consiste em compreender a ideia de "valor coletivo" das obras de arte críticas. Para esta pesquisa, presumimos que as proposições defendidas por Pasta em seu estudo estariam na base das escolhas estéticas feitas pela Brava Companhia em Corinthians, meu amor - segundo Brava Companhia Uma homenagem ao Teatro Popular União e Olho Vivo (2011), sustentando também a importância desse espetáculo dentro do debate cultural em curso na cidade de São Paulo.

A compreensão de que a cena cultural compõe um sistema complexo, que implica em produtores, críticos e públicos diversificados, não é tema novo. Todavia, a ideia não menos antiga, mas que parece ainda não ter sido levada às suas últimas consequências, de que a produção cultural é fruto de um trabalho de gerações, e só assim se inscreve na vida ideológica, é o fundamento da tese defendida por Pasta:

[...] não se trata, frente a essa produção coletiva, de se conformar a ela como a uma condição inescapável, mas de, uma vez verificada essa condição, a 
erigir a princípio formativo, ou seja, trata-se de a assumir dotando-a de valor programático e regular para o trabalho literário [...]. À preocupação de soberania - visível como procura de autonomia de sentido - a incorporação de produções alheias e coletivas vem opor sua extensão coletivizante [...] (PASTA, 2010, p.78-79).

O autor defende que as formas de recuperação e incorporação dos documentos culturais que antecedem a obra de Brecht - e a transformação de seus signos não apenas dentro da obra, mas também na relação que esta estabelece com o sistema produtivo são a base do trabalho de Brecht, no qual a construção e organização da glória e do escândalo são parte de uma interação complexa com o sistema. Assim, a produção é sempre coletiva, uma vez que remonta a um todo organizado de acordo com perspectivas de classe que podem, também estas, serem alteradas pelas obras ao vermos seus temas e formas reposicionados diante de novos contextos.

Essa ação, historicizante e produtiva, tem como fundamento a ideia de que questões centrais ao debate crítico podem e devem ser recolocadas pelos artistas, sendo que sua própria reposição no tempo já altera substancialmente as respostas encontradas, ou seja, produz avanços representativos. Nesse sentido, a retomada do trabalho do Teatro Popular União e Olho Vivo exige outra compreensão acerca de todos os seus fundamentos, apenas possível à luz de uma tradição crítica interessada na luta de classes. Essa tradição ultrapassa todo o século XX e a própria tradição teatral nacional, servindo como baliza para o debate estético contemporâneo, principalmente quando em face de uma perspectiva globalizada e totalizante da ação do Capital.

O que estaria em jogo no trabalho de Brecht seria, para Pasta, a criação de uma tradição de esquerda e de um sistema autônomo de representação, por parte das classes trabalhadoras, que coordenasse, em sua base, obras artísticas, crítica cultural e ação contra o sistema. A vinculação com o contexto social torna-se, portanto, de primeira ordem para a escolha dos procedimentos formais, e não pode ser ignorada para a compreensão do espetáculo. Em consonância com tal proposição, a relação estabelecida entre a peça da Brava e o texto original de César Vieira nos permite apreender também esse deslocamento do sistema cultural, inicialmente centrado nos meios acadêmicos e estudantis, e nas fábricas, para a periferia da cidade de São Paulo, buscando um novo público que correspondesse às novas formas de trabalho relativas ao sistema neoliberal.

No caso da Brava Companhia, sua integração no contexto periférico parte, primordialmente, da experiência objetiva de seus fundadores. Os integrantes, em 1998, 
eram todos moradores do bairro e apenas com o passar do tempo, a partir da solidificação da companhia e, principalmente, dos laços estabelecidos por intermédio das oficinas de formação, outros integrantes se juntaram ao grupo. É importante salientar que os espaços de formação, como oficinas e palestras, foram sempre tidos como espaços de pesquisa do grupo por meio dos quais se buscava, entre outras coisas, aprofundar as relações com o bairro. Consequentemente, mesmo em relação aos cursos de formação teatral - cursos livres abertos para a comunidade - a prerrogativa da investigação do corpo social subjaz ao trabalho da companhia.

Essa atitude de pesquisa, prática e teórica, coloca-se como fundamento para o trabalho da Brava Companhia e como tentativa de superar alguns impasses vivenciados pelos grupos de teatro de militância e pelos movimentos políticos da região. Conforme descreve Silvana Garcia (GARCIA, 1990) as dificuldades de grande parte dos grupos teatrais da década de 1970 residiam precisamente no quadro vivenciado pela Brava. A dedicação a uma cena teatral marginal trazia à tona problemas de ordem prática que iam desde a ausência de apuro estético em seus espetáculos até as dificuldades de manutenção dos espaços e dos projetos, já que nem sempre os grupos contavam com os apoios de financiamentos para dar continuidade a seus trabalhos.

Essa realidade foi em parte superada com a criação da Lei de Fomento ao Teatro, que pode ser vista como um resultado institucional das transformações políticas e sociais ocorridas após a ditadura e que tornou viável um projeto de teatro popular com base em uma reflexão efetiva sobre as condições reais de produção. Essa hipótese, aventada pela contribuição crítica de Paulo Arantes ao movimento de teatro de grupo que se formou a partir da consolidação da lei, é posta em xeque pela nossa análise estética do espetáculo da Brava Companhia, ainda que se exija uma comprovação historiográfica.

Ressaltar as diferenças entre os diversos projetos culturais por nós contrapostos é, de fato, premente, o que implica em diferenciar também seus pressupostos históricos. No entanto, também partimos da premissa de que há uma reposição no tempo de componentes que justificam tal continuidade, e que têm como base motivações éticas calcadas na leitura atenta da sociedade de classes e na busca por uma ação efetiva de combate à tal estratificação dentro do corpo social. 
Assim, a Brava Companhia, até fevereiro de 2016, quando o grupo decidiu encerrar sua residência no Sacolão das Artes, teve entre suas práticas organizativas a coordenação do espaço, a realização de ciclos e debates de formação, a curadoria de peças e encontros, a publicação de materiais críticos diversos e a articulação entre os demais coletivos de militância (não apenas cultural) da cidade. Essas atividades vinham, ainda, no sentido de contribuir e aprofundar uma pesquisa artística que pudesse atingir um alto nível de qualidade estética e técnica, de modo a fazer frente à cultura hegemônica.

Por conseguinte, o projeto que presumimos ter sobrevivido é, antes, o de formar um sistema cultural crítico, que incorpora o trabalhador e a luta de classes no corpo das estruturas de produção ideológica, assumindo novas configurações formais. Este projeto, que é também, sucessivamente, um dos alvos dos ataques liberais aos sistemas de representação criados pelas classes trabalhadoras, ao mesmo tempo em que apresenta o desmanche da sociedade nacional, nos obriga a reconhecer a formação de novos campos e formas de luta.

Tendo isso em vista, o primeiro capítulo de nossa análise pretende apresentar o grupo homenageado e suas perspectivas estéticas e políticas. O Teatro Popular União e Olho Vivo é responsável pela publicação de oito dramaturgias e um livro teórico biográfico, que compila suas reflexões críticas ao longo dos mais de 50 anos de atividade. Não nos dedicaremos à análise estética dos materiais, embora seja necessário reforçar a urgência de um estudo atento à contribuição dramatúrgica de César Vieira para o teatro nacional.

No segundo capítulo, iremos nos dedicar à análise do ponto de vista organizativo da peça Corinthians, meu amor - segundo Brava Companhia - Uma homenagem ao Teatro Popular União e Olho Vivo (2011), que, pautada pela história do grupo homenageado, procura um ângulo diversificado para narrar a peça escrita por César Vieira. Presumimos que é nesse ponto de vista organizativo que reside o valor coletivo da obra, haja vista a diversidade de recursos formais encontrados para sustentar a perspectiva adotada pela Brava Companhia, que parecem ter relação direta com as formas políticas registradas em nossa tradição teatral crítica.

No terceiro capítulo, analisamos, ainda que de maneira breve, o recurso da paródia (tal qual exposto na pesquisa estética da Brava Companhia) e suas implicações 
na relação com o material histórico que emerge da peça Corinthians, meu amor de César Vieira (1966). Identificamos as formas populares que são trabalhadas pelo espetáculo e buscamos problematizar a ideia de "popular" como um conceito forjado para produzir equivalências dentro de estruturas culturais opressivas, incorrendo, portanto, em risco representacional para a própria classe trabalhadora.

No quarto capítulo, buscamos descrever criticamente alguns personagens representados na dramaturgia da Brava Companhia. Temos em vista, com isso, a apreensão dos deslocamentos na representação das classes populares ocorridos entre 1970 e 2012, atentando, portanto, à transformação do mundo do trabalho, bem como à desarticulação de alguns dos termos da luta de classes para a dimensão cultural.

No quinto capítulo, procuramos analisar a protofábula que sustenta a peça, evidenciando suas relações com o trabalho do grupo em suas dimensões estética, política e militante. A expectativa de compreender a obra estética dentro de suas relações de produção e de seu contexto sociopolítico, expectativa esta que atravessa o corpo desta pesquisa, consolida-se na análise desenvolvida nesse capítulo, haja vista as intersecções entre o processo de produção e a formalização da obra. Nesse sentido, destaca-se a investigação de como o processo se revela dentro da própria forma do espetáculo.

Desse modo, nosso objetivo central é o de posicionar a peça Corinthians, meu amor - segundo Brava Companhia - Uma homenagem ao Teatro Popular União e Olho Vivo diante do seu próprio contexto, dado o fato de a obra sobrepor enunciados que procuram se encontrar na ação cultural militante da cidade de São Paulo. Seria um movimento análogo ao descrito por Pasta sobre Brecht:

É principalmente desta experiência de ação direta na vida social que surge a
concepção de totalidade característica de Brecht. [...] Considerando-se o
modo internamente motivado pelo qual o trabalho de Brecht atinge esse
verdadeiro ultrapassamento, quando este se torna uma experiência da cultura
em seus limites, torna-se ao mesmo tempo uma experiência dos limites da
obra na cultura (PASTA, 2010, p. 276, grifos do autor).

Nesse sentido, a busca por um sujeito histórico da luta de classes e por sua figuração artística ocorreria de forma prática: pela intervenção no real e ao atentar-se para os avanços da técnica e às transformações da própria sociedade, ainda capitalista. 


\section{Teatro Popular União e Olho Vivo - um fio vermelho que costura a história}

Para analisar o espetáculo Corinthians, meu amor - segundo Brava Companhia - Uma homenagem ao Teatro Popular União e Olho Vivo (2011), é necessário um recuo histórico que nos permita compreender em que consiste a homenagem, reconhecendo a importância do Teatro Popular União e Olho Vivo para a cena teatral brasileira. O trabalho realizado pelo grupo desde a sua fundação, em $1966^{3}$, tece um fio de continuidade entre as práticas culturais e militantes que atravessaram o processo ditatorial no Brasil alcançando o nosso presente e, ao tomarmos o grupo como um ponto de vista sobre a história cultural no país, muito se pode ler sobre os processos políticos em curso, dado o engajamento social com que desenvolveram suas práticas.

A busca por uma estética popular capaz de representar os impasses sociais e econômicos subscritos na base da formação nacional antecede o golpe e perpassa todo o debate cultural do período da ditadura. As divergências estéticas presentes nesse debate puderam ser observadas com lente de aumento na produção artística realizada entre 1964 e 1968 e tornaram explícitas as diferenças entre tantos projetos de nação em disputa no período anterior.

Foi como resposta aos impasses estéticos desse período que se organizou a cena da década seguinte. A análise apresentada por Roberto Schwartz em "Cultura e Política,1964-1969" (SCHWARTZ, 2008) traz os fundamentos para compreendermos tal impasse. Segundo o autor, o golpe de 1964 agiu precisamente nas propostas políticas (SCHWARTZ, 2008, p. 70-78) e estéticas que buscavam uma maior intersecção entre as camadas populares e a classe média, no sentido de transformar as bases sociais do país.

De maneira violenta, a intervenção do golpe militar rompeu o laço que ligava a produção ideológica às estruturas estatais e às massas. Essa cisão teve, por parte dos artistas, uma atitude mais formal do que militante como resposta ao processo social interrompido. Com isso, o golpe suprimia um vínculo efetivo entre a produção cultural, a militância política e a pedagogia emancipadora que se desenhava no período anterior. Tal processo, permeado por pressupostos de esquerda, vinha articulando setores

\footnotetext{
${ }^{3}$ O grupo inicia suas atividades em 1966 com o nome de Teatro dos Onze. Apenas em 1971 o grupo passa a se chamar Teatro União e Olho Vivo, para em 1973 assumir o nome Teatro Popular União e Olho Vivo, como descreve Alexandre Mate (2008).
} 
diversos da sociedade, mas a partir de 1964 passou a ser cada vez mais setorizado e circunscrito a nichos de resistência, culminando em uma profunda fragmentação do corpo político e social.

Ainda assim, herdeiro dessa inspiração igualitária e coletivizante anterior ao golpe, mas estimulado por novos ventos culturais e políticos, o Teatro Popular União e Olho Vivo inicia suas atividades pautado pelo desejo de "ida ao povo", mesmo que o contexto sociopolítico não estivesse a favor dessa prática - os laços mais sólidos já haviam sido destroçados e até mesmo a guerrilha, usada como argumento para endurecer a repressão a partir de 1968, já havia sido sufocada. A manutenção de uma atividade cultural militante se daria tão somente através de movimentos culturais clandestinos que se mantiveram à margem da institucionalização de um aparato burocrático que solidificasse os avanços liberais do regime.

Apenas assim foi possível a fundação e a continuidade do Teatro Popular União e Olho Vivo, a despeito da perseguição sofrida por alguns de seus integrantes. Embora seus primeiros passos datem de 1966, com a montagem de Evangelho segundo Zebedeu pelo grupo de teatro do grêmio XI de agosto da Faculdade de Direito da Universidade de São Paulo, a formação definitiva ocorreu somente em $1973^{4}$. Associando-se ao Teatro Casarão, responsável pela primeira encenação de Corinthians, meu amor (1966), os integrantes de ambos os espetáculos uniram-se para consolidar um projeto artístico comum.

O processo de criação de Rei Momo, peça que solidificou o grupo, teve início em 1971 a partir das premissas estético-políticas que orientam até hoje o trabalho do TUOV no sentido de buscar caminhos para um teatro popular. César Vieira, ao narrar a trajetória do grupo no livro Em busca de um teatro popular, relata que, para os envolvidos em sua fundação, alguns pontos estavam bastante claros e orientavam suas expectativas artísticas:

A certeza de que um espetáculo só chegaria verdadeiramente a um público popular se fosse apresentado nas proximidades da residência ou do trabalho

\footnotetext{
${ }^{4}$ O grupo foi oficializado apenas em 1976, todavia, segundo Cesar Vieira, sua formação data de 1973 , embora o processo criativo tenha tido início em 1971. Os agrupamentos anteriores no grupo XI de agosto, para a montagem do "Evangelho segundo Zebedeu" e no Teatro Casarão, com o "Corinthians Meu amor" são, contudo, os primeiros passos do trabalho do TUOV. Cf. Conversas Folianescas. Entrevistas. Direção: Zeca Rodrigues. Distribuição: Grupo Folias d' Arte, 2007. Há um descompasso entre os diversos documentos consultados no que se refere às datas de oficialização dos trabalhos.
} 
dessa plateia e a crença de que o preço do ingresso deveria estar ao alcance aquisitivo dessa população. Firmara-se também a convicção de que só um desvinculamento dos padrões estéticos convencionais, ditados pelo lucro e pelas técnicas estrangeiras, delinearia um caminho para uma nova criatividade, longe dos cânones da moda teatral, mas certamente mais perto do povo (VIEIRA, 2007, p. 87).

Com base em tais convicções, o grupo fez uma convocatória ampla para que novos integrantes se aproximassem do processo de criação de uma nova peça. O convite levou à participação de profissionais de diversas áreas que, em sua maioria, trabalhavam durante o dia e estudavam à noite. A partir daí o grupo posicionou-se tendo em vista uma realidade produtiva que o aproximava dos processos amadores de criação artística, escolha esta que levava em conta as realidades profissionais de seus integrantes. Os limites e as potências advindas dessa opção foram dando os contornos daquilo que viria a ser o TUOV e demarcaram também uma posição de negação do mercado cultural que fomentou as escolhas políticas do grupo. A partir das experiências de criação e circulação do novo espetáculo, Rei Momo, que englobaram desde o acolhimento inicial do projeto por parte da Faculdade de Direito do Largo São Francisco até o retorno para a lona no Ibirapuera - espaço onde haviam realizado tanto a temporada do Evangelho segundo Zebedeu, quanto do Corinthians, meu amor em 1968 -, bem como durante a circulação pelas periferias da cidade, o grupo teve o apoio de diversas instituições e encontrou, por meio desse diálogo, uma forma de dar continuidade aos seus processos de maneira independente. A prática "Robin Wood" - a venda de espetáculos para instituições que podem pagar como forma de conseguir arrecadação para apresentar a preços muito baixos nas comunidades -, que é até hoje uma das marcas do TUOV, e a articulação com associações e movimentos populares, onde os espetáculos eram apresentados e debatidos com a população, estão entre alguns dos caminhos encontrados pelo grupo para garantir sua continuidade e suas perspectivas políticas.

Dado o envolvimento com distintos movimentos sociais e associações comunitárias, e tendo em vista o objetivo de alcançar a população da maneira mais abrangente possível, o TUOV concluiria que as relações estabelecidas com o público deveriam estar no centro de suas investigações. Seria, portanto, “importantíssimo ouvir a opinião do público sobre o tema da peça, sua forma, e, principalmente, receber experiências dos moradores do local, sua vivência, aprender com eles. [...] Aprender a usar o arado e ensinar, se possível, o que quer dizer a palavra arado" (VIEIRA, 2007, p. 
101). A partir daí os pressupostos que sustentaram a criação do primeiro espetáculo e da sua temporada, que durou de 1973 a 1976, foram formulados e reformulados com base em experiências concretas junto aos trabalhadores envolvidos no processo criativo, às entidades parceiras e ao público.

César Vieira discorre sobre tais experiências ressaltando o papel central desse público na totalidade do processo e explicitando as diferentes formas investigadas pelo TUOV para que o diálogo se tornasse cada vez mais eficaz e se inscrevesse objetivamente na sociabilidade dos bairros visitados. Com isso, paulatinamente, o lugar do público dentro das encenações erigiu o princípio formal e o parâmetro de investigação estética, donde o "espectador passava de assistente a autor, e a sua vontade se expressava por aplausos, por desabafos e, às vezes até por ações... Ao final da peça chegavam a derrubar o Zé Leão do trono ou abraçar calorosamente o cidadão samba" (VIEIRA, 2007, p. 126). A expectativa de implicar o público nos processos criativos e o seu envolvimento com a peça nos dão a dimensão do experimentalismo com que o TUOV se engajara na pesquisa sobre as formas para um teatro popular e por meio do qual cativara seus espectadores.

César Vieira compara essa etapa inicial do trabalho do TUOV (VIEIRA, 2007, p. 115) à organização dos times de futebol de várzea ou à fundação das escolas de samba nos bairros periféricos, já que foi no processo de troca com a população que esta e os integrantes do grupo, todos iniciantes, começavam a formular e definir os pressupostos de investigação acerca das formas de um teatro popular que seriam adotados. Os artistas do Teatro Popular União e Olho Vivo jamais haviam circulado pelas periferias da cidade com um espetáculo, e o público, por vezes, jamais havia assistido a teatro. A experiência com Rei Momo foi, portanto, acima de tudo, uma baliza para a continuidade da ação junto às periferias, que passaria a orientar as demais produções. Ainda que os pressupostos adotados pelo grupo não consistam em regras rígidas, podendo ser transformadas de acordo com as necessidades ou a partir das exigências de um momento político diverso, aspectos políticos, organizativos e estéticos passaram a orientar as demais produções a partir de 1974. De acordo com Vieira, "a desmistificação do teatro como algo sobrenatural, misterioso, será repetida, utilizandose o que já foi testado. Tudo o que ensejou uma participação, uma ligação, uma forma 
de fazer o público pensar e uma interação com a plateia será colocado" (VIEIRA, 2007, p. 130).

Entre os pressupostos básicos para a atividade do coletivo, ressalta-se a sistematização em grupos de trabalho de todas as áreas relacionadas ao processo criativo: da dramaturgia à pesquisa, a atuação dos integrantes se daria pela ocupação de diversas funções dentro do coletivo. É de nosso interesse observar que parte significativa dessas premissas é visível nos trabalhos realizados pelos grupos teatrais contemporâneos, sobretudo na cidade de São Paulo mas não só, e corresponde a uma importante transformação ocorrida na produção teatral a partir dos anos de 1960 e 1970. Trata-se da tentativa de formulação de parâmetros estéticos e formais, bem como processuais e éticos, com base na coletivização dos trabalhos artísticos e na interação com a plateia, que passaria a ser compreendida pelos artistas como parte indissociável dessa coletividade.

Para o Teatro Popular União e Olho Vivo, essa prerrogativa é ressaltada por se tratar de uma perspectiva ética e política a partir da qual todas as suas opções estéticas são sustentadas. O grupo argumenta com veemência que o fundamento de tal prática subjaz na opção de vincular-se a questões de classe, em busca de formas que possam romper as hierarquias e os limites da cultura burguesa, de modo a produzir uma apropriação total dos seus meios de produção por parte da classe trabalhadora, bem como encontrar junto aos "populares" formas de representação que tenham por base suas experiências concretas no tecido social, ensejando uma participação política.

Tendo em vista que as proposições culturais não podem ser desvinculadas das configurações de classe, o TUOV passou a tomar as práticas da cultura popular como base para sua pesquisa estética, investigando em suas formas aspectos de resistência e confronto que não eram comumente ressaltados pela tradição literária nacional:

Esse lugar, na sociedade brasileira, tradicionalmente sofre dois tipos de abordagem. Por um lado é demarcado pela ausência, pela exclusão, pelo sinal de menos, quando se operam os valores econômicos. Por outro, faz valer o aspecto exótico e pitoresco, quando se pensa segundo a tradição romântica de localizar o excluído como sujeito do processo cultural. Macumba pra turista, na síntese oswaldiana. Alfredo Bosi reflete com pertinência sobre esses dois modos de pensar o excluído através da literatura. Sobre o primeiro, defende que a crítica sociológica deve acautelar-se, pois "a mente ideologizante abstrai as diferenças na medida em que procede à força de esquemas e tipos" e que por outro lado, as obras "reclamam atenção para o que é complexo, logo singular" (FARIA; PENNA; TONANI, 2015, p. 491-492). 
Buscando contrapor-se a esse problema, a investigação acerca de uma estética popular encampada pelo Teatro Popular União e Olho Vivo tomava a ausência e a exclusão dos trabalhadores do sistema cultural hegemônico como ponto de partida, buscando superá-la, sem, contudo, ignorar a singularidade de seus processos culturais e simbólicos. Estes, por sua vez, são tomados como referência para apreender as formas de resistência implicadas na cultura produzida por essa população. Tal oposição serve como base para a sistematização de seus trabalhos, visando produzir uma dialética entre ambos os pressupostos, capaz de fazer frente ao teor elitista que a noção de cultura carrega no contexto brasileiro. Tratava-se de reconhecer na cultura dos trabalhadores suas formas e buscar nelas aquilo que há de avançado, que ensejaria participação e resistência política diante de um sistema excludente. A proposição se diferencia, portanto, de uma prática comum diante das manifestações populares que busca "folclorizar" a cultura dos trabalhadores para melhor vendê-la.

É possível reconhecer nas intenções do TUOV uma convergência com relação às proposições de pensadores da prática teatral como Augusto Boal, Vianinha e Bertolt Brecht. Tal influencia é demarcada em diversas passagens do livro Em busca de um teatro popular (VIEIRA, 2007) e parte da premissa de que é a classe trabalhadora o único sujeito histórico capaz de realizar uma revolução social. Todavia, as formas encontradas são diversas e apontam para novos horizontes a serem investigados, sobretudo no que se refere à composição dessa classe e aos parâmetros que permitem seu reconhecimento enquanto tal.

A dimensão coletiva da construção do espetáculo, ressaltada programaticamente, traz ao debate a ideia de que sua própria feitura é um instrumento didático. O processo proposto pelo TUOV implica uma relação de duplo sentido para a consolidação de um discurso popular, que já tem início no próprio processo criativo. Seja para os integrantes do coletivo - que se envolvem tanto na pesquisa bibliográfica, quanto no trabalho de campo junto à população -, seja para o público - que se relaciona com a peça pronta, mas é convocado a agir sobre ela depois de sua estreia -, o espaço relacional produzido entre o criador/observador e objeto de estudo/objeto artístico é sempre ressaltado de modo a evidenciar perspectivas diferentes sobre um mesmo discurso. Os temas das peças do Teatro Popular União e Olho Vivo são, sobretudo, históricos e recebem um tratamento formal bastante diversificado, dado o fato de serem concebidos a partir da 
ação criativa de tantos olhares e pontos de vista diversos. Com isso o trabalho teatral se coloca como meio para, a partir daí, aprofundar-se um debate ético, estético e político que remete à esfera do trabalho e da cultura e, por consequência, da luta de classes.

Metodologicamente, isso se diferencia das propostas de Boal, ou até mesmo do CPC, os Centro Populares de Cultura, representando uma novidade no que se refere ao lugar ocupado pela cultura no Brasil e seu papel na sociedade de classes. O lugar deliberadamente amador ocupado pelo grupo e a total independência com relação a quaisquer organizações políticas historicamente consolidadas exigiram que o trabalho artístico do TUOV se tornasse também um espaço de formação teatral e política pautada, sobretudo, pelo compartilhamento de experiências. A cultura produzida pelos trabalhadores é erigida em militância e seria por meio de suas formas que uma nova luta de classes poderia emergir.

Não à toa Silvana Garcia nomeia o movimento teatral dos anos 1970 de "teatro da militância" (GARCIA, 1990). Embora não se trate de um movimento uniforme, à época a produção teatral na periferia da cidade de São Paulo contribuía para a resistência à ditadura e para a militância social e cultural, assumindo um importante papel. Além de participar na articulação política dos trabalhadores, os grupos teatrais apontavam criticamente para questões como o nacionalismo, os processos migratórios, o trabalho informal em ascensão e a formação de um proletariado crescente nas cidades à margem das organizações sindicais, impasses de primeira ordem para que possamos compreender as pressões do período.

De maneira coadunada com tais transformações, observavam-se inovações profundas no que se refere aos modos de produção teatral, já que, na medida em que os artistas travavam contato com as comunidades periféricas (organizações de bairro, movimento operário e com as comunidades eclesiais de base), formava-se também uma frente de trabalho militante chamada por Marcos Napolitano (2011) de "nova esquerda". As novas formas de organização politica que emergiram na década de 1970 foram também bastante caracterizadas por Eder Sader em seu livro Quando novos personagens entram em cena (1988) e consistem na articulação entre movimentos sociais menores, que lutavam sobretudo por melhorias na qualidade da vida objetiva dos trabalhadores. Este movimento de esquerda caracterizado pelos dois autores encontravase implicado com o trabalho de base e com proposições diversas daquelas oriundas da 
esquerda clássica, vinculada ao PCB (Partido Comunista Brasileiro), embora mantivesse uma relação bastante próxima com as classes trabalhadoras.

Ainda que as pesquisas de tais grupos do "teatro da militância" tivessem como pressuposto uma investigação estética com base em questões semelhantes, não chegou a formar-se uma frente de ação comum, seja ela política ou estética, que tenha sustentado a ideia de um movimento propriamente artístico. Por sua vez, as transformações no que se refere aos modos de criação sugerem que, artisticamente, algo diverso apontava no horizonte estético de tais grupos:

\begin{abstract}
Essa opção [de ir até a periferia] trazia embutida a necessidade de encontrar um elemento diferencial também no que concernisse à linguagem dos espetáculos. Os grupos procuravam investir na produção de espetáculos capazes de atrair o novo público e garantir um elo de solidariedade entre os artistas e as comunidades periféricas (GARCIA, 1990, p. 273).
\end{abstract}

Cada coletivo, portanto, respondia a sua maneira ao contexto social que os circundava, empreendendo pesquisas diversas que tinham por base as relações com as comunidades. O impasse entre as questões formais e os sistemas de financiamento para a produção cultural do período traziam à tona problemas de ordem prática, que incorriam, por vezes, na ausência de apuro estético de alguns dos espetáculos, ou nas dificuldades de manutenção e continuidade dos projetos de pesquisa, inviabilizados pelas dificuldades de subsistência dos grupos. O Teatro Popular União e Olho Vivo, por sua vez, é um caso emblemático para o período, pois além de resistir e produzir teatro, manteve seu engajamento político e militante, encontrando procedimentos formais que viabilizassem suas perspectivas éticas.

Contudo, como ressalta Iná Camargo Costa no ensaio "Brecht e o teatro épico no Brasil" (COSTA, 2012, p. 127) foi apenas de maneira clandestina que se tornou possível essa investigação capaz de permitir a sobrevivência e a continuidade dos trabalhos de grupos como o Teatro Popular União e Olho Vivo. Dada essa realidade, a importância de sua ação sobre o imaginário público só pode ser notada a contrapelo, lendo-se o processo a partir do movimento teatral contemporâneo - igualmente caracterizado por uma diversidade de linguagens e perspectivas - e à luz de sua contribuição histórica para a consolidação desse mesmo movimento. Isso se deve a duas questões: primeiro, pelo fato de que uma arte pública tão somente pode ser lida a partir 
de seu lugar no debate público. Em segundo lugar, devido ao fato de que os atores sociais que se articulavam naquele momento traziam para o debate proposições diversas daquelas sugeridas pela tradição de esquerda vinculada ao PC. Isso dificultava a compreensão de achados formais por parte de uma crítica cultural que buscava no arcaboço teórico da União Soviética suas referências analíticas, contribuindo para um relativo apagamento dessa voz emergente.

Não obstante, acompanhando a pista deixada por Iná Camargo Costa, é possível reconhecer nas práticas desses grupos os fundamentos daquilo que viria a ser o movimento "Arte contra a Barbárie" e o ressurgimento, a partir dos anos 2000, de um teatro militante nas periferias da cidade, alimentado pelas vitórias políticas desse mesmo movimento. Também nesse sentido, é de primeira ordem salientar a participação de alguns personagens como César Vieira - cujo nome verdadeiro é Idibal Piveta, sendo César Vieira um nome artístico criado para contornar a censura -, Luis Carlos Moreira (do Engenho Teatral), Dulce Muniz e Celso Frateschi em tal movimento. O que escapa, contudo, dos apontamentos de Iná Camargo Costa são as transformações estilísticas preconizadas por tais artistas e grupos clandestinos, e as formas encontradas por eles para dar conta do processo social que a ditadura produzira. Como relata Vieira em entrevista concedida a Reinaldo Maia em 2007, a abertura trouxe consigo um desejo muito amplo de liberdade de expressão, e a partir daí gradativamente grupos com perspectivas éticas convergentes retomaram um debate que pode "ressuscitar" alguns dos pressupostos do teatro de grupo que haviam sido silenciados ${ }^{5}$.

A pertinência dos esforços encampados por esses artistas tinha como horizonte levar adiante os anseios de popularização da prática teatral e das questões de classe que fundamentavam os avanços formais dos CPCs e do Teatro de Arena. Por sua vez, a realidade social os obrigava a criticar as nuances populistas e nacionalistas que sustentavam tais práticas, encontrando novas formulações distintas do dirigismo com que o PCB se posicionava junto às classes trabalhadoras.

Na biografia do TUOV, César Vieira afirma que as experiências teatrais de seus antecessores foram determinantes para a linha estética e política desenvolvida pelo grupo (VIEIRA, 2007, p. 65). Contudo, à luz das observações feitas por Silvana Garcia

\footnotetext{
${ }^{5}$ Cf. Conversas Folianescas. Entrevistas. Direção: Zeca Rodrigues. Distribuição: Grupo Folias d' Arte, 2007. Minutagem aproximada: $1: 10-1: 14$.
} 
(1990) acerca da diversidade encontrada no teatro militante do período, bem como assumindo a interlocução com Iná Camargo Costa (2012) no que se refere aos antecedentes do teatro épico no Brasil, não podemos deixar de salientar que foi a força política e social latente no processo histórico nacional que levou à erupção da forma épica e de um teatro político em solo brasileiro, e não a expectativa de inserção em uma tradição europeia. Nesse sentido, o agitprop $^{6}$ e suas proposições também compõem o quadro histórico necessário para compreendermos o processo de maneira complexa.

$\mathrm{O}$ teatro de Brecht, que impulsionou parte significativa da dramaturgia do $\mathrm{CPC}$ e do Arena, chegou ao Brasil oficialmente em 1958, segundo afirma Iná Costa (2012, p. 121) e sobretudo ao longo da década de 1960, as formas de produção e criação na cultura entraram para o debate estético. Impulsionado pelo fato de que a crítica ao stalinismo exigia novas formas de arte política uma oposição simplificadora entre individualidade e coletividade, racionalismo e irracionalismo nas artes, passaria a permear o debate estético, associando participação a uma atitude engajada - com muitos prejuízos à compreensão de algumas formulações estéticas -, e crítica ao sistema econômico e político a uma atitude autoritária.

O teatro épico de Brecht, por sua vez, é incompreensível sem a relação crítica, no sentido dialético, do mesmo Brecht com o agitprop alemão. Aqui temos um nó: o que foi resultado crítico - no sentido de apontar limites - dos experimentos de agit prop (por Brecht), aqui no Brasil, está na origem da nossa principal experiência de agit prop. [...] no caso do CPC, o resultado crítico de uma experiência alemã esta na origem da mesma experiência criticada. Sem dialética não se entende isso (COSTA, 2012, p. 122).

A questão da participação do público, por sua vez, e as formas para que um engajamento com acontecimento estético e político pudesse ocorrer entrariam na ordem do dia e passariam a ser amplamente investigadas:

Também por razoes de contra revolução, aqueles que teoricamente estariam aptos para fazer a experiência brechtiana avançar - os comunistas brasileiros - eram exatamente os menos aptos para essa tarefa, problema decorrente da

\footnotetext{
${ }^{6} \mathrm{O}$ teatro de Agitprop, agitação e propaganda, é uma forma de teatro de cunho político que teve o seu inicio na União Soviética durante o processo da Revolução Russa. Tratava-se de um amplo movimento cultural que buscava fazer a propaganda dos temas da revolução e incitar a população a se envolver na transformação da sociedade. Esse movimento, a partir da vitória da revolução, foi inicialmente apoiado pelo Estado Soviético, sendo inclusive institucionalizado e tendo suas frentes autoativas desaparecido a partir de 1922.
} 
história da própria revolução soviética. Brecht era persona non grata na União Soviética e, por conseqüência, para os comunistas brasileiros formados na ortodoxia da terceira internacinal. [...] Os comunistas brasileiros não gostavam de Marx, não gostavam de dialética (COSTA, 2012, p.122).

À luz de tais consideração de Iná Camargo Costa podemos compreender a partir de que premissas o trabalho de Brecht se aproximaria do trabalho do Teatro Popular União e Olho Vivo. Seja por meio dos reflexos dos movimentos culturais dos operários e anarquistas italianos imigrados, como defende Silvana Garcia (1990), seja de maneira retrospectiva - à luz da recente publicação organizada por Costa, Estevam e Villas Boas (2016), Agitprop: cultura politica, que apresenta as formas estruturais do Agitprop -, observamos que as proposições do Teatro Popular União e Olho Vivo parecem dialogar com as formas organizativas deste último e do teatro didático de Bertolt Brecht, ainda que, devido à pouca bibliografia disponível em português, a hipótese seja de difícil comprovação. O que podemos subtrair das experiências do grupo, em contraste com o debate crítico da época é, antes, o desejo de implicar a classe trabalhadora na vida pública e nas transformações concretas da sociedade, o que exige uma participação direta, que poderia ser aprendida por meio da experiência estética e cultural. Proposições como as de Augusto Boal para o Teatro do Oprimido e dos situacionistas ${ }^{7}$ franceses, formuladas mais ou menos na mesma época, correspondem a outras tentativas de explorar essa temática, já que buscavam configurar, igualmente, uma dialética entre uma estética crítica e a construção objetiva de uma nova sociedade com base no acontecimento estético.

Todavia, reconhecer as diferenças e semelhanças implicadas em cada uma das propostas - que possuem um mesmo horizonte de transformação, ainda que refletindo bases sociais muito distintas -, é de extrema relevância para compreendermos os movimentos culturais da atualidade, posto que a similitude entre as práticas não alcança necessariamente objetivos comuns, dados os contextos sociais muito diversos. A democratização da cultura, que está na base da prática do TUOV corresponde a um

\footnotetext{
${ }^{7}$ O movimento situacionista - Internacional Situacionista - ocorreu na França nos anos de 1950 e 1960 e seus escritos e proposições estiveram em pleno diálogo com os levantes estudantis de 1968. Entre suas proposições artísticas estava uma revisão política dos usos dos espaços através da realização de diferentes "situações" e práticas sociais. O principal autor vinculado ao movimento é Guy Debord e ressaltamos aqui tais proposições dado ao fato de a Brava Companhia ter entre suas referências teóricas o livro "Sociedade do Espetáculo", onde Debord problematiza a então nova configuração do capitalismo (SITUACIONISTA, 2002).
} 
momento do processo político nacional em que horizontes revolucionários já não estavam mais na ordem do dia, diferentemente de casos como o teatro épico de Brecht ou o CPC, embora a luta contra a ditadura exigisse uma atitude militante e ativa de embate contra o sistema.

Uma característica "democratizante", portanto, subjaz no trabalho do grupo e expressa tanto os avanços quanto os limites de suas proposições. Em luta contra a ditadura e preparando o terreno para uma redemocratização política, o período foi marcado pela articulação de diversas entidades civis e pelo deslocamento considerável de alguns dos pressupostos da esquerda clássica. A maneira encontrada por esses agentes sociais para se contrapor ao processo em curso tinha como ponto de sustentação a sociabilidade urbana e práticas culturais em seu sentido mais amplo (não limitadas a práticas artísticas). Essa esquerda, nova sobretudo no que se referia às pautas, era composta a partir de lutas como o Movimento do Custo de Vida, o Movimento da Saúde e o "novo sindicalismo", com o apoio direto das comunidades eclesiais de base, que tinham um papel fundamental na articulação entre as diversas mobilizações. Mantendo-se um sentido comum, que associava suas reivindicações à restituição de um estado democrático, a luta dos trabalhadores no Brasil alcançaria seus máximos feitos no final dos anos de 1970 com a fundação do PT, que tinha como horizonte de transformação a disputa institucional do aparelho do Estado, não mais a revolução, e que convergia grande parte desses movimentos sob a bandeira de um partido.

Em paralelo a essas novas formas organizativas, também uma nova forma de pensar e produzir cultura emergia. O importante estudo realizado por Marcos Napolitano (2011) torna-se, portanto, fundamental para se compreender o amplo aporte de forças em tensão na produção artística do período, diretamente atuantes sobre as proposições do Teatro Popular União e Olho Vivo. Sua contribuição também nos permite observar um problema de ordem metodológica no que se refere aos estudos acerca dos processos culturais do período. Ainda que uma frente unificada de resistência ao regime tenha se formado a partir de 1968, incorporando liberais, comunistas e a contracultura, a década de 1970 trouxe à tona uma enorme pluralidade de opiniões, revelando posicionamentos diversos em todos os setores sobre as formas e propostas por meio das quais se daria uma efetiva resistência ao regime ditatorial. Contudo, como contraponto a essa realidade, o autor afirma que: 
As alianças eram tensas, precárias e fluidas. [...] Sintomaticamente, o discurso jornalístico fez tábula rasa de todas as posições da resistência cultural construindo uma memória de consenso que, no fundo, afirma apenas a hegemonia liberal que tem marcado a democracia brasileira (NAPOLITANO, 2011, p. 12).

Embora os novos atores e personagens da política nacional pertencentes a essa nova esquerda tenham obtido o reconhecimento público (sobretudo devido à visibilidade de suas práticas, como as greves, por exemplo), a produção artística que se originaria no mesmo contexto acabou estigmatizada pela crítica, por ser associada a um "obreirismo ${ }^{8}$ idealista realizado em nome de uma cultura popular classista e comunitária" (NAPOLITANO, 2011, p. 14). Todavia, o fundo comum às práticas dessa nova esquerda, e que estava sendo investigado em termos também formais por esses artistas engajados, expunha, de fato, uma profunda crítica ao nacional popular ${ }^{9}$ e às perspectivas populistas, além de pressupor a "sociabilidade urbana" e o cotidiano como materiais a serem investigados, fosse para fundamentar novas práticas militantes, fosse para produzir novas formas artísticas.

Torna-se evidente, pela perspectiva de Napolitano, que houve uma opção historiográfica para o período, responsável por alçar a contracultura, o tropicalismo e a MPB ao mais alto grau de importância no que se refere à sua narrativa cultural. Essa opção deu-se justamente pela ação dos setores liberais da burguesia, responsáveis pela formação da indústria fonográfica e pelo fortalecimento da indústria cultural de massas.

Os liberais deram bastante espaço para os artistas ligados à chamada "corrente hegemônica" (comunista) como demonstra a mencionada presença de comunistas declarados entre os quadros artísticos e técnicos da TV Globo, ou o prestígio que os cantores e compositores da MPB desfrutavam nos jornais liberais ou junto às empresas fonográficas (NAPOLITANO, 2011, p. 33).

8 A ideia de um "obreirismo" se caracteriza por proposições em que somente o proletariado estaria habilitado a conduzir o processo revolucionario, excluindo-se, portanto, intelectuais e artistas das lutas por transformação social.

${ }^{9}$ A política do Nacional-popular buscava fortalecer a ideia de nação tendo como foco o desenvolvimento econômico do país e o fortalecimento das instituições estatais, na mesma medida com que valorizava uma cultura popular que pudesse uniformizar uma identidade nacional. Para compreender suas complexidades ver: ORTIZ, Renato. ORTIZ, Renato. Cultura brasileira e identidade nacional. São Paulo: Brasiliense, 2006. MOTA, Carlos Guilherme. Ideologia da Cultura Brasileira (1933-1974). 4.ed. São Paulo: Editora Ática, 1978. 
O interesse em fortalecer a unidade nacional era estimulado pelo próprio Estado ditatorial, tendo em vista a necessidade de fortalecer o patriotismo para que a abertura democrática pudesse ocorrer de acordo com as necessidades do livre mercado. O ponto comum entre os setores liberais e os setores da esquerda forjou uma oposição entre sociedade civil e Estado ditatorial, que vem sendo problematizada pelas interpretações contemporâneas do processo e que passou a ser lida como uma ditadura civil-militar, reconhecendo a atuação dos setores liberais e conservadores na configuração do golpe:

[...] a liberdade de expressão e a volta da democracia nas instituições de governo, criando duas figuras políticas contrapostas: sociedade civil e estado, como se ambas não fossem perpassadas por contradições, divisões e conflitos entre os diversos agentes sociais que as constituíam (NAPOLITANO, 2011, p. 191).

Ainda que o consenso de luta contra a ditadura tenha imperado, as divergências no que diz respeito ao projeto de país e concernente à intensa segmentação social que compõe a sociabilidade nacional permaneceu latente. $\mathrm{Na}$ cultura, isso incluía questionamentos sobre a massificação da produção cultural, o público a quem se destinava a arte e, sobretudo, a respeito das relações que essa arte deveria manter com o mercado, trazendo à tona divergências que fundamentavam uma cena cultural bastante diversificada. Para a arte engajada, as perguntas que se colocavam referiam-se, principalmente, ao questionamento acerca do público ideal para essas produções e às formas e conteúdos necessários para se relacionar com esse público.

Marcos Napolitano (2001) torna explícito que o debate entre PCB e essa nova esquerda, que de fato impulsionavam para um novo tempo da organização política nacional, apareceu de forma reduzida no que se refere a suas perspectivas culturais e artísticas. A produção cultural do período foi lida, nesse processo, sem que fossem feitos os devidos ajustes relativos a uma análise formal capaz de aprofundar as implicações de seus achados estéticos para o seu próprio tempo. Enquanto a corrente hegemônica vinculada aos liberais e à indústria de massas tornou-se o paradigma da resistência cultural, as práticas dos grupos de "teatro da militância" tiveram seus reflexos minimizados, dada também a dificuldade de ler o processo no calor da hora. Em todos os sentidos aquilo que se apontava dizia respeito a uma nova configuração das forças produtivas, o que só se mostraria em sua complexidade tomando-se uma distância que não era possível no momento. 
A principal crítica à produção dos artistas vinculados a este trabalho militante, afirma Napolitano, (2011, p. 195) recaía no tom de apologia, donde a paixão pelo rústico e pelo popular era acusada de fundamentar uma prática de representação que era confundida com proletkultismo por parte de correntes ligadas ao PCB. Todavia, dada a distância histórica com que observamos o debate, é possível reconhecer que as principais divergências estavam ligadas ao processo de formalização dos trabalhos, que se opunham às orientações estéticas de cunho realista propostas pelo PCB e propunham uma nova leitura acerca da composição de classes presente na sociabilidade urbana. Observa-se também que os papéis destinados ao "povo" e ao "intelectual" implicavam novos protagonistas para processos políticos e sociais, e eram centrais ao debate. As esquerdas, em todo o mundo, passavam por uma revisão crítica que buscava compreender qual o lugar desses dois importantes personagens na luta de classes, levando-se em conta as críticas dirigidas ao "socialismo real" e à União Soviética. Tendo isso em vista, o debate acerca da apropriação de matrizes culturais populares, sempre carregado de visões controversas no que se refere a seus usos, tornou-se a voga do debate estético e mantém a sua centralidade se quisermos analisar historicamente os deslocamentos ocorridos no campo estético nos últimos 50 anos.

A busca por uma estética que, como propõe o Teatro Popular União e Olho Vivo, fosse pautada pelo "ideário de um teatro popular com princípios éticos e estéticos que corroborassem com a valorização das pessoas de classe popular, para sua afirmação como classe capaz de orientar criticamente seu próprio destino" (CARLETO, 2009, p. 50) não correspondia aos pressupostos que desqualificavam a produção artística dos grupos militantes. Ainda que os trabalhos fossem criticados por serem associados a uma atitude apologética, ingênua e populista, sem alcançar um apuro formal adequado, afirmando com isso sua verve opressora, para autores como Fernando Peixoto, ligado à corrente do nacional-popular e vinculado ao $\mathrm{PCB}$, as duas vertentes não eram incompatíveis, sendo, por sua vez ambas "necessárias para a recuperação da cena brasileira" de modo a buscar-se uma terceira via para o teatro de "temática popular" e o teatro de "produção popular". Ainda assim, as principais críticas a esse procedimento de apropriação de matrizes culturais populares vinham, segundo afirma Napolitano, das correntes de esquerda, que pouco atentavam para o fato de que o cerne dessa produção estava em reconhecer as diferenças sociais, regionais e econômicas ocultadas sob o 
ideário de "nação", questionando, assim, a legitimidade do conceito ao reduzi-lo a mero folclorismo.

Essa terceira via pode ser observada na produção do TUOV, posto que o grupo se esforça para não proclamar ambiguamente a apologia de que a tradição cultural popular seja algo perdido que sempre deve ser resgatado, a despeito das contradições conservadoras que possa carregar. A observação atenta das manifestações culturais populares tornou-se parâmetro primordial para o processo criativo do grupo, sem nunca abdicar de outros materiais que lhe fossem contrapostos. Os folguedos populares, o carnaval, o samba, o futebol e as inúmeras dinâmicas dos encontros populares converteram-se em matéria-prima, na qual os artistas se esforçam por reter apenas aquilo que sugira potência transformadora, distanciando os aspectos conservadores de maneira crítica.

Não apenas as estruturas diversificadas presentes na cultura popular, mas também o debate acerca das perspectivas de luta política mediadas por um cotidiano de resistência faziam parte do complexo debate cultural militante do período. Nesse sentido, a subsistência do grupo foi questionada e problematizada, buscando-se o afastamento de uma atitude idealista, na mesma medida em que se reconhecia na independência econômica das práticas culturais populares a força da sua sobrevivência.

César Vieira descreve com clareza os caminhos que levaram o futebol de várzea, a capoeira, o samba e o carnaval a se tornarem paradigmas de atuação para o grupo, ressaltando as formas organizativas dos coletivos populares. Em certo sentido, a desconfiança com relação ao aparelho estatal e ao mercado está nas bases de tais práticas. Daí a ideia de uma prática "Robin Hood" para a manutenção de suas atividades, sugerindo uma malandragem popular que não adere à política institucional, ainda que possa fazer uso de algumas de suas benesses. A contribuição de Carleto para a compreensão do trabalho do TUOV vai no mesmo sentido, demonstrando como tais formas organizativas encontram raízes nas dinâmicas de sobrevivência e subsistência dos grupos tradicionais de cultura popular para se perpetuar.

Tendo isso em vista, a postura crítica que associava essas produções ao proletkultismo soviético não estava em tudo errada, como nos sugere a tese de Silvana 
Garcia $(1990)^{10}$, tendo apenas não atentado a aspectos formais, produtivos e estéticos presentes no agitprop russo, sobretudo nos movimentos autoativistas que emergiram nos primeiros anos da revolução. Marcados pelo desejo de "reivindicar seu papel na construção das novas relações sociais e no seio desta, erigir seu espaço cultural próprio, fora da cultura hegemônica das outras classes no caso, em oposição à cultura burguesa" (GARCIA, 1990, p. 7), o autoativismo tinha como pressuposto a multiplicação dos agentes e a ação dos núcleos de bairro e operários para a construção de uma nova cultura direcionada a uma sociedade que estava nascendo.

A cena, nesse caso, cumpriria

[...] o papel de disseminador dos ideais da revolução, enquanto organiza e alimenta a ação cultural dos trabalhadores, consolidando consequentemente a própria revolução. Essa ação cultural conduz a uma formulação estética que engendra uma nova ideia de teatro [...] O teatro de agitprop superou-se a si enquanto proposta e produto. Nesse sentido, o teatro de agitprop representa uma subversão espontânea das formas tradicionais e uma radicalização dos procedimentos da vanguarda até o limite mesmo do seu não reconhecimento enquanto teatro (GARCIA, 1990, p. 19-20).

A pesquisa formal dos grupos de agitprop se daria motivada basicamente por dois fatores: a relação com o espectador e o vínculo com a história presente, sendo que a “investigação de linguagem parte da busca por uma adequação a objetivos políticos de envolvimento e participação" (GARCIA, 1990, p. 20-21), necessários para viabilizar a revolução. A participação do espectador no momento da apresentação se daria como ponto culminante de um processo de envolvimento com o todo da produção da sociedade. Militância, participação política, crítica social e a destruição da institucionalidade burguesa se dariam na mesma proporção como ação na realidade e como linguagem.

$\mathrm{Na}$ estética do Teatro Popular União e Olho Vivo, não podemos nos furtar de reconhecer a convergência nas intenções. $\mathrm{O}$ desejo de busca por um teatro popular aliado às questões de classe - ainda que se reconheça uma configuração de classes que abarca o lumpemproletariado, profissionais liberais e do setor de serviços - corresponde às novas inflexões do problema. Todavia, não apenas o processo do grupo é marcado

\footnotetext{
${ }^{10}$ No trabalho a autora associa criticamente trabalhos de agitprop russos e alemães, a frente militante anarquista formada no Brasil, o trabalho realizado nos Centros Populares de Cultura, CPCs e alguns grupos atuantes na periferia durante os anos de 1970. A proposta visa um amplo levantamento de experimentações artísticas militantes.
} 
por tais intenções militantes, como também formalmente na cenografia, na música, nos jogos de distanciamento e identificação e no esforço em explicitar a facilidade com que os recursos técnicos podem ser apropriados pelos novos artistas (aspecto esse que por vezes é associado a precariedade formal). Todos os elementos estão ali com o objetivo de potencializar o diálogo e a participação do novo público.

Das suas proposições é impossível não tomar como pressuposto os novos atores que estão em cena e o desejo de que sejam eles os responsáveis pela construção de uma nova sociedade, sem classes. Ao se apropriarem dos meios de produção de todos os elementos necessários à construção de um espetáculo teatral, os populares também se apropriariam das possibilidades de construção de uma nova cultura e de uma nova sociedade. O processo, como reconhece César Vieira (2007), é longo e árduo; contudo, a esse longo processo "decidimos chamá-lo ação coletiva pois não podemos aplicar-lhe o nome de espetáculo, de representação ou de encenação" (GARCIA, 1990, p. 28). Trata-se de socializar ao máximo o processo de feitura dos objetos culturais, de modo a instituir um espectador privilegiado que não apenas frui a apresentação, mas participa crítica e ativamente de todas as etapas de montagem, apropriando-se do debate público.

Todavia, diante das prerrogativas que reivindicam a "autonomia da obra de arte", essas proposições não podem ser lidas ou interpretadas desconsiderando-se a relação intrínseca entre produção artística e institucionalidade cultural. Como defende Peter Burger (2012), a imanência da obra de arte é, a despeito de suas intenções, inscrita em algum padrão de linguagem, o que lhe confere historicidade. Assim, quando comparamos o trabalho do TUOV aos grupos de agitprop, não podemos ignorar que as proposições encontram correspondências, embora os grupos autoativos tenham, por fim, perdido sua autonomia para o Estado e, quando começa a imperar a ideia do realismo socialista, já não há mais muito a ser resgatado desse movimento. Até mesmo os experimentos didáticos de Bertolt Brecht já eram uma formulação crítica ao movimento de agitprop, pautada, sobretudo, na ausência de dialética imposta pela propaganda do partido; a forma por meio da qual as análises estéticas do Proletkult Soviético chegam à crítica cultural da década de 1970, portanto, compõem esse quadro controverso, que apenas pode ser compreendido diante do debate acerca da instituição artística, sua destruição ou refuncionalização (BURGER, 2012, p. 154-157). Assim, compreender a historicidade das formas de agitprop produzidas em solo brasileiro não pode suplantar 
os achados formais desse movimento em outros momentos da luta de classes, embora se exija também que seja lido a partir de seu próprio processo histórico, fazendo jus à tradição teatral com a qual se alia criticamente e com a qual estabelece um diálogo direto.

Nesse sentido, a permanência dessas ideias no imaginário cultural assume uma forma diversa, que não se fundamenta na sua formalização estética, mas nos seus pressupostos éticos e processuais. Não à toa, a despeito da contribuição de muitos pesquisadores, o trabalho realizado pelo TUOV recebeu poucas análises atentas à sua contribuição formal, ainda que a produção do grupo tenha sido amplamente premiada e sua dramaturgia esteja inteiramente publicada. Talvez seja apenas pela ação coletiva que poderemos lançar luz aos seus ganhos formais e às descobertas estilísticas que advêm desse processo de radicalidade na pesquisa de campo e na militância política.

Embora Marcos Napolitano ateste que esse movimento não teve forças para ultrapassar a abertura democrática, consideramos aqui a hipótese de que esteja no bojo dessa movimentação política e artística sustentada por essa nova esquerda $a$ consolidação de um aparato estatal democrático que fundamenta as demandas contemporâneas de politicas públicas para a cultura. As práticas "basistas"11 e democratizantes que eram compartilhadas por seus representantes tinham em comum uma crítica ao nacionalismo, ao vanguardismo e à aliança de classes, o que levava a uma profunda revisão da cultura política do nacional-popular e embasava a ideia de "consciência cidadã" e de "sociedade civil" que orientou, em diversas frentes, tais reivindicações. Também a criação do PT, em 1980, coroou o processo como uma expressão organizada dessa corrente, embasada em ideais comunitários que propunham práticas bem definidas como "democracia comunitária, voluntarismo ativista e participativo, conscientização a partir das lutas cotidianas, direitos humanos e justiça social" (SADER, 1988), o que tirava o embate contra o capitalismo da ordem do dia, embora tivessem a crítica ao sistema econômico como base.

A posição do $\mathrm{PCB}$, por outro lado, que era a de manter uma produção crítica associada à luta de classes, ainda que por meio da aliança liberal, levou à criação do

\footnotetext{
${ }^{11}$ Práticas basistas são práticas políticas pautadas pela relação com os movimentos de base, formados por trabalhadores, em que se busca articular políticas e pautas de luta que tenham relação direta com as populações. Em sentido mais amplo, também o trabalho de base, que tem como fim popularizar um certo discurso em meio à população, ganha esta nomenclatura, embora com fins diversos.
} 
Plano Nacional de Cultura, PNC, que, sob a acusação de "estimular uma cultura brasileira 'nacional-popular' sem luta de classes" (NAPOLITANO, 2011, p. 209), seria transmutado, com a abertura neoliberal, em institucionalização por meio de leis de incentivo fiscal e do mecenato oficial. Nos anos seguintes, essa prática tornar-se-ia objeto de crítica por parte dos movimentos artísticos, ainda que a luta de classes não retornasse mais ao centro do debate.

Portanto, contrapondo-nos à argumentação de Napolitano que afirma que tais movimentos culturais militantes não tiveram forças para utrapassar a abertura democrática, consideramos que ambas as ideias se enraizaram, igualmente, nas práticas que se seguiram e podem ser identificadas nas proposições do movimento "Arte Contra a Barbárie" e na estética dos grupos contemporâneos. As feições daquilo que fora produzido pelo teatro de militância da década de 1970 e do movimento de teatro de grupo dos anos 2000, ainda que demarcando momentos distintos do processo de democratização da cultura (e do país), parecem manter um diálogo direto com o debate travado por essas duas correntes do pensamento de esquerda, embora se trate de uma esquerda já com novas características.

A participação do público e a dimensão processual dos trabalhos, todavia, erigiram o princípio formal e exigem da crítica uma nova atitude, com base em novos parâmetros de análise. Não à toa a vitória do movimento "Arte contra a Barbárie" foi coroada com uma lei de fomento ao teatro para a cidade de São Paulo, para a sua população e feita por ela, ainda que a crítica não esteja necessariamente atenta a essa exigência dos novos tempos da produção cultural.

Em polos opostos da narrativa, encontramos em 1970 a articulação profunda entre uma crítica à sociedade de classes, o trabalho de base, a militância e os diversos setores da sociedade sustentando o projeto de democratização da cultura que foi levado a cabo pelo Partido dos Trabalhadores. Do outro lado, em 2012, observamos que a vitória do movimento dos artistas, que levou à institucionalização dessas práticas, tendo como base os mesmos pressupostos, não encontra mais a ampla sustentação da força militante. Vemos, portanto, o seu conteúdo combativo dissipado pela ausência de um debate pautado pelas mesmas questões. Essa situação parece ter se agravado com a chegada do Partido dos Trabalhadores à presidência, ainda que os programas culturais tenham garantido uma relativa democratização do acesso à produção. 
Nesse sentido, suspeitamos que quando a Brava Companhia assume o ponto de vista histórico do Teatro Popular União e Olho Vivo para narrar esse processo, o grupo está, mais uma vez, colocando-se na busca por um teatro popular e convocando para o debate uma tradição crítica e estética que possa dar suporte para os problemas contemporâneos da cena cultural e política. Essa procura é a mesma empreendida pelo Teatro Popular União e Olho Vivo, que buscou em seus antecessores, CPC e Teatro de Arena; que buscaram, por sua vez, em Brecht; que buscou, por seu turno, no agitprop cada qual, em suma, em seus contextos e momentos históricos específicos, buscando as formas necessárias para representar criticamente o atual estado da luta de classes. 


\section{Tradição crítica e o valor coletivo do trabalho teatral}

O cenário é um bar. Algumas mesas estão espalhadas pelo ambiente e duas arquibancadas ocupam as laterais do espaço. A decoração é cheia de detalhes que buscam trazer um ar naturalista à cenografia do local: bibelôs de times de futebol, garrafas de bebida barata e fotos de grupos de teatro como se fossem "times" de futebol de várzea. A luz é fria, concreta, ilumina tudo igualmente, revelando a precariedade da cena. Churrasco e cerveja são servidos enquanto os atores acomodam o público pelo espaço, ocupando, inclusive, as mesas que estarão dentro de cena. Um balcão de bar, decorado como um altar ou relicário e situado em uma das pontas do salão, e uma roda de samba conferem ao ambiente uma familiaridade que nos distancia do papel de espectadores e nos convida a participar da cena. A certa altura todos os atores reúnemse próximo ao balcão, o acontecimento ganha ar de representação e os atores cantam agora para o público - um famoso samba que dá início ao espetáculo Corinthians, meu amor - segundo Brava Companhia - Uma homenagem ao Teatro Popular União e Olho Vivo (2011).

A peça tem como enredo "a vida na capital paulista, que gira toda ela, em todos os setores, ao redor do Sport Club Corinthians Paulista e dos trabalhadores e trabalhadoras torcedores do então time do povo" 12 , e passa-se toda nesse boteco de periferia, criado com inspiração nos mutirões "para encher laje" que ocorrem frequentemente nos bairros periféricos. Público e atores ocupam o mesmo espaço como participantes de uma espécie de "festa popular", um encontro que homenageia o grupo Teatro Popular União e Olho Vivo, um dos mais antigos da cidade em atividade contínua desde 1966.

A narrativa, episódica, atravessa o espetáculo dividindo-o em duas camadas de apreensão que se sobrepõem, produzindo uma relação contraditória interna ao material. Ao mesmo tempo em que o público é convocado a participar do espetáculo pela disposição dos elementos de cena e pela sua própria posição dentro do espaço cênico sendo, inclusive convidado a atuar em algumas cenas -, elementos de distanciamento

\footnotetext{
12 Texto do release da peça, fornecido pela Brava Companhia.
} 
surgem por meio da música e da exploração dos recursos técnicos, que produzem um anti-ilusionismo de caráter historicizante.

O prólogo do espetáculo é composto por dois movimentos que diferenciam essas camadas de apreensão. A primeira cena, "A Concentração", nos introduz à primeira camada e sugere um plano em que o "acontecimento em si" - como ação de encontro proposto pelo grupo para receber todas as pessoas ali presentes - torna-se parte estruturante do espetáculo teatral.

Correspondendo à nomenclatura clássica da preparação que antecede uma partida de futebol, "A Concentração" é a cena que acabamos de descrever, em que o público é recebido pelos atores em um bar, de maneira descompromissada e receptiva. Sambas populares são cantados coletivamente como forma de remeter a uma "manifestação popular agregadora, que fala da história e dos problemas do povo, que tem origem no povo, para o povo"13, chamando à participação. Em sentido contrário ao adotado pelo vocabulário futebolístico, onde a concentração é um momento de reclusão, com regras rígidas de alimentação e descanso, a proposta do grupo é antes um momento de fartura e compartilhamento, que tem como função preparar público e atores para o "jogo teatral."

Uma segunda camada, na cena seguinte, explicita o acontecimento estético ao apresentar um grupo de artistas organizando seu discurso e preparando seus interlocutores para uma situação de jogo cênico que terá início naquela arena. Conduzidos pela Brava Companhia, acompanharemos a estrutura narrativa, baseada no texto Corinthians, meu amor, de César Vieira (1966), que busca, esta sim, representar a vida de trabalhadores e trabalhadoras da cidade de São Paulo. A partir de então observaremos uma narrativa bastante simples: nesse bar, em um dia de jogo do Corinthians, há também uma reunião de militantes comunitários ocorrendo. Como o bar costuma ser frequentado pelos moradores do local para assistir aos jogos, eles não percebem a presença dessa reunião no local e decidem ficar por ali mesmo cantando louvores ao time, ainda que a televisão do local esteja quebrada. Um morador, um "palhaço" que é também um bandido procurado pela policia, soluciona o problema do grupo roubando um televisor e o instalando no local. Todavia, quando o aparelho chega, o jogo de futebol já acabou. A partir de então o bar é “invadido" pela televisão, e as

\footnotetext{
${ }^{13}$ Texto do release da peça, fornecido pela Brava Companhia.
} 
cenas representadas passam a figurar alegoricamente a ação da indústria cultural sobre o imaginário popular. A peça encerra-se, por sua vez, com uma última cena, também alegórica, que figura um jogo de futebol no qual a disputa entre o time popular e o time da elite evidencia um conflito interno à própria classe trabalhadora, que leva à derrota do "União Popular Futebol Crubi".

Como anfitrião desse encontro e fazendo a mediação entre ambas as camadas de apreensão, temos o personagem Olho Vivo recebendo os populares para se divertir em seu boteco, mas sempre esperando que alguma politização possa nascer desse encontro. A temática da união popular faz frente a toda a estrutura formal da peça, recorrendo ao ponto de vista de Olho Vivo como forma de remeter ao grupo homenageado e convocar uma atitude crítica ativa. A escolha de configurar para essa obra um ponto de vista organizativo que nos remete a uma ação coletiva e histórica, que vai além da ação do TUOV, traz ainda mais importância analítica ao conjunto do objeto. Se tomarmos como base o fato de que a década de 1970 indicava um sentido ascendente no que se refere às possibilidades de união e organização popular - capazes de serem vislumbradas, seja no texto original, seja na ação do grupo homenageado -, e que a Brava Companhia se depara, em 2012, com as dificuldades de um horizonte negativo em relação às possibilidades de organização e mobilização, torna-se premente a necessidade de analisar criticamente a origem de tais impasses ante esse processo histórico.

Por vezes a repressão promovida pelo mercado parece tão nociva para a produção cultural e para os movimentos populares quanto a própria ditadura. A descontinuidade dos processos organizativos e de luta que caracteriza a política brasileira aparece representada pela peça à luz dessa dificuldade de sobrevivência dos movimentos, aspecto este cujo golpe de estado de 1964 é o maior sintoma. Tendo isso em vista, o movimento cíclico de tentativas de organização popular e rupturas ou impedimentos de tal organização estrutura a narrativa de maneira fragmentada, consolidando o corpo do problema. Trata-se de representar algumas horas de um dia qualquer em um boteco periférico, mas um dia que não passa, ou seja, não encontra solução para o problema, visto que o embate renasce "mais uma vez desde a sua estreia em 1966" (BRAVA COMPANHIA, 2015, p. 201). Esse movimento da narrativa contribui para a compreensão do arco histórico sobre o qual a peça se debruça, tendo em 
vista o interesse da companhia em dialogar com a trajetória do grupo homenageado, estabelecendo relações de comparação com situações contemporâneas.

\subsection{O ponto de vista do Olho Vivo - a ação histórica do Coringa}

As relações entre Corinthians, meu amor - segundo Brava Companhia - Uma homenagem ao Teatro Popular União e Olho Vivo e o texto original são pautadas pela alteração do ponto de vista narrativo. De uma câmera filmadora que assume uma perspectiva nacional-popular de abordagem, envolvida com a insipiente formação da indústria cultural no país, como é o caso da versão original, escrita em 1966, passamos a ver, na versão de 2011, o ponto de vista de um personagem, o Olho Vivo, que interfere no espetáculo como um mestre de cerimônias representante de todo um movimento teatral, fazendo as vezes de militância política à margem dessa mesma indústria de massas.

Em toda a estrutura da peça, Olho Vivo se destaca por uma consciência de sua interlocução direta com o público, o que leva o personagem a fazer comentários e dar conselhos, sendo inclusive o responsável por apresentar as regras do jogo teatral que terá início naquela arena. Diferente dos demais personagens que interagem com o público de maneira dramática, suas intervenções transitam entre estilos diversos ao longo do espetáculo, recorrendo, por vezes, a aparatos técnicos como o rádio ou a televisão, a partir dos quais amplia e dinamiza suas colocações. Ao fazer uso do recurso da colagem, o narrador rompe com o espectro dramático das cenas, propondo uma análise crítica também sobre os modos de produção e reprodução da cultura.

O personagem, portanto, personifica um novo ponto de vista organizador para a obra, não se atendo à sua perspectiva individual, mas amplificando-se para uma dimensão que abarca uma coletividade de grupos teatrais e culturais, incluindo tanto a Brava Companhia quanto o Teatro Popular União e Olho Vivo e tantos outros grupos que atuam sistematicamente na periferia da cidade. Ao mesmo tempo, o personagem é dramaticamente fundamental para o curso dos acontecimentos e para a existência do encontro que se firma naquele espaço, assumindo uma função central na narrativa que nos obriga a observar com atenção qual é o papel desempenhado por ele. 
A narrativa, por conseguinte, apenas tem inicio quando Olho Vivo soa o apito. A partir de então, no rádio do boteco, ouve-se o locutor de um jogo de futebol apresentando as regras do jogo teatral que terá inicio ali. O recurso à linguagem futebolística empreendido, sobretudo pela dramaturgia, opera como um vocabulário comum entre o público e os atores. O domínio da população sobre as regras do jogo de futebol permite um acesso direto às regras que são propostas pela Brava Companhia para esse novo jogo.

\footnotetext{
Estão concentrados. O palco já está armado para mais este espetáculo. O público comparece a mais esta função que renasce mais uma vez desde a sua estreia em 1966. Na ocasião o técnico César Vieira. Hoje, com outro elenco a função se desenrola: Corinthians, Meu Amor! Vem hoje escalado pela Brava Companhia, todos canhotos, para fazer dos minutos que se seguirão momentos inesquecíveis pela beleza ou pela feiura de seus fazedores e seus feitos. Estão de um mesmo lado o público e os artistas deste espetáculo que jogarão no limite dos seus saberes até o tilintar do apito final. Olho Vivo! Olho Vivo! Por sorte ainda aparecem nos campos da vida, embora muito de vez em quando, alguns atrevidos que saem do roteiro e cometem o disparate de driblar o time adversário inteirinho, pelo puro prazer do corpo que se lança na proibida aventura da liberdade. Comeeeeeeça o jogo! (BRAVA COMPANHIA, 2015, p. 201)
}

Como podemos observar, o fragmento instaura alguns pressupostos por meio dos quais os espectadores poderão se relacionar com a peça. $\mathrm{O}$ arco temporal feito pela narrativa deixa claro que Olho Vivo irá operar de maneira historicizante, amarrando os quadros e cumprindo também o enlace crítico dos diversos fragmentos. Também o lugar destinado ao público, que jogará no mesmo time da Brava Companhia, é uma regra que deverá ser apreendida de antemão pelos espectadores - pretendemos tirar consequências analíticas que não escapem a essa perspectiva de cunho histórico e coletivo. No mesmo sentido, ao evidenciar a participação de dois times em campo, não podemos nos furtar de observar as fotos de tantos outros "times" culturais, parceiros da Brava Companhia, espalhados pelo boteco como se fossem times de um movimento de teatro de várzea que ultrapassa o próprio espetáculo e propõe uma analogia direta com o movimento de teatro de grupo da cidade de São Paulo.

Parece-nos inescapável ressaltar mais uma vez que, para César Vieira e para o Teatro Popular União e Olho Vivo, as referências teatrais do Teatro de Arena e do CPC são fundamentais para a proposta artística que foi levada a cabo a partir dos anos de 1970. Para tanto, torna-se premente a necessidade de revisitarmos a tradição teatral 
crítica do período, retomando aspectos do debate proposto por Iná Camargo Costa, Roberto Schwarz e Anatol Rosenfeld para compreendermos de que se trata esse movimento.

Tendo isso em vista, o Sistema Coringa, tal e qual apresentada por Augusto Boal, fundamenta, para nós, o papel desempenhado por Olho Vivo. O princípio formal, desenvolvido pelo autor entre 1964 e 1968 consiste em um personagem que assume a função de um comentarista "explícito e não camuflado" (ROSENFELD, 1996a) em meio a uma representação dramática de cunho histórico. O Personagem do coringa, portanto, remete a uma consciência outra, de caráter épico, dentro da estrutura narrativa, assumindo para si a articulação dos fragmentos representados e produzindo uma relação empática com o público. Desenvolvido sobretudo na criação de peças que buscavam conclamar um espírito de resistência ao estado ditatorial, como "Arena conta Zumbi" e Arena conta Tiradentes", e recorrendo a personagens heróicos da história nacional para buscar promover este sentimento de insurgência, o sistema proposto por Boal foi um diferencial na cena do período sobretudo pela nova forma de dialogar com o público, já que propunha uma relação direta e de identificação com problemas e questões "de um jovem paulistanos de 1967" (ROSENFELD, 1996a).

Contudo, a novidade com a qual nos deparamos é de outra ordem autorreferenciada e metalinguística -, posto que o personagem na peça da Brava Companhia, além de instituir uma distância histórica para a leitura dos diversos fragmentos, também explicita um lugar de onde se lê, ou seja: um movimento teatral sobretudo aquele em diálogo com a periferia da cidade.

A primeira fala do nosso Coringa remete à constituição desse ponto de vista, apresentando-nos os sujeitos de uma narrativa e seus feitos heroicos. Por sua vez, ela também nos ajuda a apreender o seu "tom", à luz de um olhar contemporâneo não heroicizante, respaldado por uma tradição teatral que se diferencia daquela pertencente à cultura dominante, e não por uma "grande personalidade, indivíduo excepcional, modelo, inspiração nacional” (ROSENFELD, 1996a, p.15). Essa diferença, fundamental para a forma de Coringa desenvolvida pela Brava Companhia, parece divergir dos propostos de Augusto Boal, buscando criar, de partida, um herói coletivo, em oposição a uma figura que personifique esse gesto. Por meio de paralelos com o time do Corinthians, a peça nos fala também sobre a formação do Teatro Popular União e Olho 
Vivo, sobre sua história e sobre suas expectativas de atuação política, já que o desejo de auxiliar na organização política de trabalhadores ligados a entidades e comunidades periféricas estava no cerne de sua atuação nos anos de 1970.

Com isso, o que se apresenta é um "heroísmo anônimo" (BOAL, apud ROSENFELD, 1996a, p. 49) mais próximo daquilo sugerido por Anatol Rosenfeld (1996a) acerca das peças didáticas, nas quais, pelo que indica o autor, o conceito de herói não se aplica. Em contraponto à ideia de Boal, que sugere que Brecht "amplia o número dos heróis, sem destruir nenhum” (BOAL apud ROSENFELD, 1996a, p. 49), para Anatol Rosenfeld há antes uma crítica ao conceito, posto que "a ampliação do numero de heróis aniquilaria a sua condição excepcional de herói” (ROSENFELD, 1996a, p. 49). Nesse sentido, o Coringa Olho Vivo não poderia ser associado à ideia de um herói e as homenagens prestadas ao TUOV presumem um processo mais amplo e coletivo, que ultrapassa até mesmo as importantes ações e práticas promovidas pelo grupo.

\footnotetext{
Olho Vivo - Gente, que bom que vocês vieram. É uma felicidade ter vocês aqui. Isso que tá acontecendo aqui hoje, me lembra primeiro de setembro de 1910, quando cinco trabalhadores -2 pintores de parede, 1 sapateiro, 1 motorista e 1 trabalhador braçal, fundaram o Sport Clube Corinthians Paulista. Cinco trabalhadores... Trabalhadores como nós, que se juntaram e fundaram - cá pra nós - o maior time de futebol do Brasil. E hoje nós, trabalhadores também, tamo aqui... Tudo fudido!... Ah! Antes que eu me esqueça... Essa cena chama: "Organização Interrompida". Agora Fulano vai conversar com a gente sobre alguns problemas da comunidade ... Valeu gente! E ó!... Qualquer coisa eu tô aqui. (BRAVA COMPANHIA, 2015, p. 202).
}

A composição original do Time do Corinthians, formado apenas de trabalhadores, aponta para a composição do Teatro Popular União e Olho Vivo, elucidando os sujeitos históricos implicados nos processos. A ausência de datas precisas e o fato de que os momentos de ruptura da organização popular não se mostram de maneira nítida nas cenas conferem ao recurso histórico uma certa opacidade. Contudo, a análise atenta dos demais elementos nos leva a concluir que este é o ponto central sobre o qual se debruça o espetáculo: as dificuldades de uma efetiva união e mobilização popular, repetidamente inviabilizada. A fala da militante que se segue, tentando convocar a todos para uma mobilização contra os despejos no bairro, e que é interrompida pela chegada do Coro de Corintianos, nos remete a dois turnos de 
tentativas de organização popular, um em 1964, e outro, contemporâneo, em meados dos anos 2000. Essa ambiguidade temporal apenas se torna perceptível se considerarmos o nome da cena - "organização interrompida" -, a interferência de Olho Vivo, que busca dar continuidade na reunião, e seu desfecho saudosista, que remonta a um espírito idealista de outra época.

Do ponto de vista de Olho Vivo, a potência de organização e luta está latente e tem por pressuposto a energia de "corpos que se lançam na proibida aventura da liberdade" (BRAVA COMPANHIA, 2015, p. 202). A identificação com os cinco trabalhadores que fundam o maior time do Brasil nos dá a ver o papel central do trabalhador na organização política, até certo ponto, ao mesmo tempo em que deixa claro que a partir de um dado momento histórico, "nós, trabalhadores também, tamo aqui... tudo fudido!" (BRAVA COMPANHIA, 2015, p. 202). Para compreendermos as colocações de Olho Vivo em chave histórica, que é a perspectiva convocada pelo personagem quando organiza seu discurso de maneira reflexiva, é indispensável retomar o texto original, bem como a trajetória do grupo Teatro Popular União e Olho Vivo e sua prática teatral ao longo dos anos de 1970.

Corinthians, meu amor, de César Vieira (1966), remonta a uma utopia da militância política e cultural. Com base nas práticas do CPC e do Teatro de Arena pré1964, ainda ouviam-se ecos de luta e resistência em uma parcela dos produtores culturais que ambicionaram uma rearticulação política pós-golpe nas periferias da cidade de São Paulo. Alguns dos pressupostos de tais anseios podem ser vistos neste fragmento do texto de 1966, embora já seja possível capturar, também, algumas contradições do período.

Pois é, o coração de São Paulo é um clube de futebol. Um clube nascido em 1910 na cidade provinciana. Surgido do engajamento do povo no esporte aristocrático de então: o futebol. O jogo trazido da velha Inglaterra. E o operário, o carvoeiro, o pedreiro sentiram que naquele quadrilátero, com aquela bola, eram iguais, senão melhores, que o patrão, o doutor o chefe... E do povo nasceu o Corinthians. E com o Corinthians o povo se afirmou. Sentiu ali uma igualdade negada em todos os demais setores e esmerou-se em manter essa igualdade... E do povo, do Corinthians, espraiaram-se milhares de campos de futebol, cidade afora, igualando todos, superando divergências, unindo tudo (VIEIRA, 2008, p. 53-54). 
A união do povo, em luta contra a ditadura, era a linha mestra da produção cultural quando o texto foi escrito; contudo, o que de substancial havia na produção cultural anterior ao golpe, ou seja, a relação com os sindicatos, com o campesinato e com os movimentos sociais, fora fraturado pela ação do golpe e perseguido por todo o período que se seguiu. A frente artística que se formou entre 1964 e 1968 teve seu papel inequívoco para dinamizar esteticamente o debate e, inclusive, propor críticas acerca dos erros da esquerda no período que sucedeu ao golpe. Com isso, a ode positiva com que César Vieira conclama a proliferação de milhares de campos de futebol cidade afora surge, em seu tempo, como ato de resistência que evoca o legado do CPC, e tendo sido levado a cabo por diversos grupos teatrais nos anos de 1970, ainda que sem os laços organizativos que lhe davam suporte. O "esporte aristocrático" por meio do qual a população pobre podia se sentir igual ou melhor do que o patrão viria a ser o teatro, conforme encampado pela prática dos grupos de teatro militantes; a cultura popular, sobretudo com raiz nos processos migratórios; e também o Corinthians, como "unidade popular" que se opunha às formulações nacionalistas criticadas pelos autores dos anos de 1960. Essas tentativas de unificação apontavam para um questionamento do nacional-popular que ganharia sua expressão máxima na produção cultural da década seguinte.

Embora haja certa resistência de compreender a movimentação cultural militante da década de 1970 como uma frente única de atuação por parte de alguns críticos, é digno de nota que o movimento chegou a formar nas periferias da cidade uma grande quantidade de grupos amadores que, por meio do teatro, dinamizavam questões locais e compunham uma vasta rede de solidariedade, fazendo frente à ditadura. Caracterizado pela mobilização de muitas diferentes organizações de ativismo político, esses grupos passaram a reconhecer no trabalhador urbano e em suas demandas novos vetores para a ação política, que os levavam a se aliar a organizações como os movimentos de moradia, comunidades eclesiais de base, clubes de mães, lutas pela saúde, entre tantos outros fragmentos da luta. O próprio time do Corinthians, na década de 1970, teve um papel político relevante de participação nessa "nova esquerda" e em suas práticas militantes.

Como contraponto a essa orientação positiva e idealista com que César Vieira conclama a proliferação dos grupos pela cidade, a Brava Companhia, no refluxo desse 
movimento, é obrigada a ler em chave crítica o processo atravessado pelo Teatro Popular União e Olho Vivo. A constatação do que ficou fora da cena política do período, ou seja, as desigualdades que foram ocultadas pelo desejo de se criar uma união popular nos anos precedentes, retorna à cena, manifesta exatamente na cidade zona que, aparentemente, ganhou a atenção dos holofotes no período, principalmente devido à ação da cultura e dessa proliferação de coletivos artísticos.

Olho Vivo - Pois é, o coração de São Paulo é um time de futebol.

Nasceu em 1910

Do povo nasceu o Corinthians

O povo sentiu a igualdade que nunca teve

A igualdade que nunca teve

Ele é a história de uma cidade, de uma cidade

A... Igualdade que nunca teve (BRAVA COMPANHIA, 2015, p. 206).

A união que aparentava se estabelecer nos anos de 1970, com base na figura do trabalhador e na atuação da sociedade civil e que foi responsável, inclusive, por contribuir para a fundação do Partido dos Trabalhadores, parece já não encontrar mais eco nas práticas políticas contemporâneas. Nesse sentido, o ponto de vista de Olho Vivo na peça da Brava Companhia ressalta a ausência da figura do trabalhador no debate público contemporâneo, tentando apontar, timidamente, onde estariam os novos vetores da desigualdade e da luta, que tomam forma, ambas, a partir da própria constituição de uma cidade desigual.

Ainda que o Coringa Olho Vivo busque, ao longo da peça, remeter ao trabalho para instaurar um campo comum de diálogo com o público, os elementos que se referem ao universo cultural são os que melhor se articulam e se colocam no centro do problema. A apresentação dos personagens que integram o "Coro de Corintianos" nos dá a ver que o espectro do mundo do trabalho com a cultura pode assumir diferentes nuances, dependendo de suas relações com o mercado cultural. Temos representados na peça um palhaço miserável, uma jornalista idealista e um cantor de pagode, entre outras figuras que se relacionam com a constituição simbólica da periferia da cidade e seus agentes. Findas as apresentações, o Coringa faz uma ressalva ao público para que aceite a precariedade dos elementos de cena e volta a convocar o público a participar da representação, dessa vez requisitando a perspicácia do olhar para que possamos apreender o problema como um todo: 
Olho Vivo - [...] E para que o teatro possa ter pleno efeito sobre vocês, solicitamos que... Fiquem à vontade! As bebidas são de procedência duvidosa, mas as cadeiras.... é as cadeiras também. Pede-se para não atirar nos atores, fazemos o melhor que podemos. Impedidos ou não nossa intenção nesse jogo é jogar. Nossa estratégia em campo: teatro popular, união...

Todos - E olho vivo!

Olho Vivo - Esse é o nosso lema, essa é a nossa bandeira. Esta história não é piada, não tem herói, nem galã...

Marcito - Exceto uma ressalva! Referindo a si próprio

Olho Vivo - Não passa na televisão ... é tão somente parte da nossa história, da história do povo... anuncia a música. "Abre o olho que o olho é vivo" (BRAVA COMPANHIA, 2015, p. 208).

Embora em sua fala o Coringa convoque a união, a Brava Companhia tem como lema "Olho Vivo", mote que dá nome ao personagem sobre o qual estamos debruçados. A separação dos termos "teatro popular, união e olho vivo" na passagem desassocia as três ideias contidas no nome do TUOV, sob a batuta de um olhar crítico e aguçado que deverá analisar os dois outros termos do conjunto: o teatro popular e a união. Com isso, retornamos à pergunta fundamental sobre a história contada pela peça: mas como, por sua vez, pensar uma história do povo em 2011 sem a televisão?

Tendo isso em vista, um debate quase metalinguístico sobre a representação das camadas populares se faz necessário. Formalmente, a peça ganha corpo ao assumir as divisões estilísticas do épico e do dramático, aprofundando-se em imagens que se contrapõem àquelas veiculadas pela mídia. O tecido do espetáculo propõe novas resoluções cênicas para tal divisão estilística, calcadas na performance vivenciada pelo conjunto. $\mathrm{O}$ acontecimento em si, o encontro entre público e atores, é o que fundamenta a comunhão política em curso e, associado à estetização desse acontecimento por meio da representação, ganha viés crítico.

A presença de um Coringa dentro da cena instaura o que seria para Anatol Rosenfeld (1996a) uma dupla camada de representação, com o propósito de que, ao mesmo tempo em que se vivencia uma experiência, possamos comentá-la, distanciandonos dela. O propósito de vermos "a ideia tornada experiência e a vivência tornada ideia" (ROSENFELD, 1996a, p.46), defendido por Boal, é levado à cena por um estilo teatralista que, "reunindo a função épica do coringa e a função protagônica da dramaticidade naturalista, realiza a síntese de dois métodos fundamentais do teatro moderno" (ROSENFELD, 1996a, p.46). À luz desse sistema, o Coringa de Boal transita 
livremente na cena, comentando os ocorridos com a consciência crítica de um grupo jovem de 1967.

No caso de Olho Vivo, o Coringa da Brava Companhia, são outros os ventos que sopram, e revelam-se através da cena tanto as dificuldades para se reconhecer um sujeito ideal da luta de classes, como a ausência de um inimigo comum contra o qual possam se contrapor os personagens,. Dessa forma, não vemos na cena nada de heroico ou positivo que se salve na representação. A camada que seria tomada como "dramática" é de uma miséria sem igual: todos os personagens estão na viração ${ }^{14}$, tentando se salvar por meio da autopromoção e da malandragem. Como já ressaltamos anteriormente, o fato de que todos, artistas e público, jogam do mesmo lado, além de instaurar uma regra para o jogo teatral em questão, também evidencia a ausência de antagonistas ou protagonistas dentro da situação vivenciada, o que já alude a uma importante diferença ante o sistema proposto por Boal. Com isso, também essa camada “dramática" traz elementos diversos, relativos a novas formas de produção e reprodução da cultura, em que o próprio conflito, inerente ao drama clássico, encontra-se rebaixado e quase desaparece.

Já a camada épica, de onde partem as reflexões críticas e comentários mais conscientes, tem por base um processo histórico que se relaciona, sobretudo, com a dimensão cultural. É essa consciência sobre o trabalho da cultura e suas diversas funções dentro da luta de classes que articula os elementos, o que não é pouca coisa em vista de uma sociedade em que uma das principais mediações é a indústria cultural de massas. Na medida em que a Brava Companhia reconhece quem é o seu público e as questões que estão postas para a produção cultural contemporânea, a companhia encontra, por meio da perspectiva de Olho Vivo, formas para reposicionar um debate cultural. Tal debate, que parece também pertencente a um outro tempo, sugere mais uma ruptura na organização política que vinha sendo gerada, e na qual o movimento teatral teve importante papel. O distanciamento, portanto, problematiza o apagamento dos conflitos inerentes àquela situação representada.

\footnotetext{
14 Viração é um termo que vem sendo utilizado para qualificar as dinâmicas de trabalho informal vigentes na contemporaneidade, entre as inúmeras formas encontradas pela população para "se virar e ganhar um pouquinho mais". Desenvolvidas principalmente com o fim de possibilitar uma renda mínima para a população, os trabalhos na "viração" não exigem formação e não possuem qualquer tipo de registro no Ministério do Trabalho, mantendo-se completamente à margem dos direitos trabalhistas.
} 
A comunhão que se dá na relação com o espaço é de onde a Brava Companhia engendra as principais diferenças com relação aos pressupostos de Boal. As proposições do Sistema Coringa preconizadas pelo autor têm por base a necessidade de que o personagem produza uma relação de empatia com o público, motivada por meio de uma consciência análoga à sua, ou seja, da identificação com os seus pressupostos. Nesse sentido, o Coringa da Brava Companhia se diferencia por não operar essa função mítica do processo, com o qual o público se identificaria, exaltando-o como herói. A empatia necessária para o sucesso do sistema de Boal é deixada a cargo da relação com o espaço do boteco de Olho Vivo, onde todos os populares se identificam igualmente com suas práticas e formas sociais.

A proposição formal tem por base uma noção política de cidade que acabou por reavivar a disputa de imaginários acerca da problemática da luta de classes. Todavia o problema parece ter sido reavivado não mais assumindo-se o trabalhador como sujeito revolucionário mas sim, sob a alcunha de "Sujeito Periférico" que desloca do trabalho para a cidade o campo das disputas. Com isso, a empatia com o Coringa é também uma empatia pela periferia, pelas suas questões, formas, temas e, principalmente, pela sua população. Já a análise crítica e os paralelos com o processo histórico ressaltado pelo personagem do Coringa, à luz da trajetória do Teatro Popular União e Olho Vivo, destinam-se, sobretudo, para um movimento de teatro de grupo e de ação políticocultural que se quer militante.

Quando nos deparamos, na última cena, com um embate protagonizado por “populares", temos a real dimensão de que este Coringa não tem condições de produzir identificação entre todos os presentes a partir dos mesmos pressupostos. A cena evidencia, na concorrência e na disputa entre iguais, um impasse cultural a ser superado se quisermos nos opor a um sistema econômico opressivo como o neoliberalismo. $\mathrm{O}$ fato de que a Brava Companhia tem por público uma composição diversificada, diferente daquela que participava das peças do Teatro de Arena, exige novas formas de constituir a empatia com o público.

A hipótese analítica para onde o espetáculo parece apontar sugere, por meio do ponto de vista de Olho Vivo, que novas tentativas de mobilização popular foram buscadas ao longo dos últimos 50 anos, sendo, por sua vez, igualmente inviabilizadas, ainda que por intermédio de novas práticas, menos explicitamente repressivas. $\mathrm{O}$ papel 
decisivo da indústria cultural é representado como forma de desarticular, na base, o conflito latente. Ainda que a hipótese careça de um ajuizamento minucioso sobre as características específicas de cada uma das tentativas de organização representadas, o fio condutor representado por Olho Vivo abarca, além de César Vieira ${ }^{15}$ e dos demais integrantes do grupo, outras personalidades ligadas à cultura e à militância na cidade de São Paulo. Também fazem parte dessa comunidade diversos coletivos culturais representados na peça pelos cartazes que remontam a outros times homenageados no boteco -, que vêm bebendo de fontes comuns para a constituição de uma projeto cultural emancipador e capaz de fazer frente ao mercado de bens simbólicos.

Desse modo, a prática empreendida por esses agentes ocupa, inequivocamente, um espaço no imaginário de uma parcela dos grupos que integram o atual movimento de teatro de grupo na cidade, sobretudo aqueles que se aliam diretamente a causas populares e a práticas políticas junto às periferias. As resoluções formais encontradas pela Brava Companhia parecem vir no sentido de aprofundar pressupostos formais de grupos que, como o Teatro Popular União e Olho Vivo, ficaram reconhecidos, principalmente, pela qualidade da inserção e inscrição dos processos junto às comunidades periféricas, tendo suas proposições estéticas, contudo, pouco analisadas. Comprova-se, com isso, que o modo de produção e criação desses grupos, para além da "qualidade estética" e ética, consiste em uma sofisticada forma de representação de classes, atenta às particularidades de seu público e às segmentações internas à própria classe.

Isso apenas se faz notar quando, dada a distância histórica empreendida pela Brava Companhia no trato com o texto original, o ponto de vista de Olho Vivo "corrige", criticamente, alguns dos impasses com que se deparava a produção teatral da Nova Esquerda militante nos anos de 1970, na mesma medida em que convoca a potência de suas práticas e resoluções formais. Também no que se refere ao papel delegado ao Estado e ao mercado ante a produção cultural, a tensão se explicita ao

15 A participação de César Vieira em diferentes momentos da organização do teatro de grupo em São Paulo, por meio também de sua atuação como advogado, contribui para a análise. Idibal Pivetta é não somente um importante defensor dos direitos humanos durante a ditadura, como também participa ativamente na criação da Cooperativa Paulista de Teatro, em 1979, e do movimento "Arte contra a Barbárie". 
conjugar perguntas acerca da militância amadora, do trabalho de base e da necessidade de sobrevivência dos artistas, questões estas centrais para a produção cultural à margem.

Marcos Napolitano descreve o movimento de teatro dos anos de 1970 como um front de recusa e crítica radical (NAPOLITANO, 2011, p. 192), atestando, ainda, que haveria ali uma dupla recusa, ao Estado e ao mercado, como base para suas práticas. $\mathrm{O}$ autor não se furta a compreender que a contrapartida dada aos artistas que sofriam com a repressão foi a sistematização de instituições culturais do Estado brasileiro, como a Funarte e a Embrafilmes, além da criação de modelos de financiamento destinados a uma parcela da produção. No caso do TUOV, a recusa a essa mercantilização da cultura nacional, promovida com o aporte do Estado ditatorial, foi responsável por formular toda a sua trajetória estético-política. A partir da crítica à centralidade de um nacionalismo simbólico, crítica essa que se contrapunha à incorporação da pluralidade das culturas populares e de suas vivências comunitárias aos modelos estéticos da indústria cultural de massas - e, sobretudo, à supervalorização dessas práticas -, o grupo optou por permanecer à margem tanto da indústria cultural, quanto dos financiamentos privados, atuando de maneira amadora e militante junto às classes trabalhadoras e grupos populares.

O personagem Olho Vivo aponta, portanto, para o papel do mercado e, principalmente, do mercado cultural, em suas mais diversificadas formas, para apresentar as dificuldades de mobilização política. À luz desse contexto, as inserções dramáticas do nosso coringa no curso da narrativa conjugam também uma autocrítica da experiência realizada pela Brava Companhia junto à comunidade do Parque Santo Antônio e ao movimento de teatro de grupo da cidade. Pode-se observar essa atitude desconfiada do personagem quando, ao ver seu bar sendo autoritariamente transformado em locação para um programa de televisão, Olho Vivo questiona a negociata, posto que a promoção não contribui para a vivência política almejada pelo personagem. Dada a sua consciência crítica, Olho Vivo prefere fazer uso do estabelecimento para tentar organizar a população e deixar suas portas abertas para receber reuniões da comunidade do que ser promovido a novo novo espaço cultural da quebrada.

Trazendo à cena um certo tom de proximidade, de festa popular, com inspiração na atitude militante dos grupos dos anos de 1970, mas engendrando nesse encontro personagens e problemáticas que dizem respeito a um contexto bastante diverso da 
organização política, a todo momento o personagem tenta chamar a atenção do grupo para a urgência da (re)união política. A mercantilização e a mitificação do futebol aparecem como um impedimento à organização, por ofuscar a atenção do grupo em relação a todos os outros problemas. Todavia, até mesmo a união que resplandece na ação do "coro de corintianos" dá a ver a possibilidade de afronta como gesto coletivo da cultura futebolística. O mesmo coro representa, portanto, a massa de torcedores, alienada pelo ópio do povo, fundamentando a crítica às formas de ação coletivas mercantilizadas e conservadoras, como também uma noção de reconhecimento coletivo que busca no futebol o seu potencial agregador e de tomada de um espaço historicamente elitista:

Olho Vivo - Que é isso?! Que falta de respeito é essa? Eu emprestei o bar pra comunidade porque tá acontecendo uma merda aqui na nossa cara! A prefeitura tá mandando todo mundo embora! Tão passando com o trator em cima da casa de todo mundo! Passaram com o trator em cima da casa da Dona Maria Pretinha, sua vizinha... A gente precisa fazer alguma coisa... silêncio total E outra: não vai dar pra ver o jogo aqui não, a televisão quebrou. Indignação total dos torcedores, grande confusão.

Cotonete - Peraí, pessoal! Peraí! Não tem televisão, mas não tem problema... nós vamos ver o jogo no rádio mesmo! Porque o mais importante é que nóis tamo tudo aqui, junto, unido... Nesse espaço que é o coração dessa comunidade! (BRAVA COMPANHIA. 2015, p. 204)

O fato de que o despejo da vizinha esteja ocorrendo, além de gerar constrangimento no grupo de populares, não enseja nenhuma atitude ou reflexão, sequer empatia. Por outro lado, a ausência do televisor, e até mesmo a solução encontrada por Cotonete de ouvir o jogo pelo rádio, não apenas despertam a atividade do grupo, como viabilizam a permanência dessa massa heterogênea no mesmo espaço, que se torna, com efeito, o coração daquela comunidade.

As possibilidades de envolvimento e de engajar a empatia daquele coletivo são capitaneadas por Gabriela, a estudante de jornalismo e representante tipificada da ação da indústria cultural entre aqueles populares. A personagem demonstra, em uma sequência de perguntas e respostas, que os corações de todas as cidades do mundo são suas imagens de resistência. Sendo assim, o Harlem, bairro dos negros, é o coração de Nova Iorque, Che Guevara, o coração da Argentina, e o Corinthians é ovacionado por todos como o coração de São Paulo, conclusão essa melancolicamente questionada pelo coringa Olho Vivo. 
A passagem nos permite entrever a potência de resistência presente naquele espaço e na convivência tête-à-tête de tantos personagens e tipos distintos na construção da mesma cena. A fala de Cotonete, nesse sentido, é central para entendermos o quadro, já que, para ele, sua presença no espaço comunitário aberto por Olho Vivo pulsa mais do que o próprio amor pelo Corinthians. Ainda assim, nada além da identificação com o time parece criar um laço de solidariedade e reconhecimento possível interno ao "Coro de Corintianos", que por vezes se dissolve repentinamente, desaparecendo da cena. Dessa forma, é também Olho Vivo quem aponta para o individualismo dos integrantes desse grupo, ressaltando os elementos de crítica por meio do gestus dos personagens representados. Logo depois da primeira derrota do time, o coro se desfaz e o personagem comenta: "Então é assim... cada macaco no seu galho. Cada trave com seu goleiro. [...] E a bola é pesada demais para se agarrar sozinho" (BRAVA COMPANHIA, 2015, p. 210). Contudo, retomando a força idealista de outrora, Olho Vivo ainda busca em alguma luta contemporânea esperança para o grande jogo final. Vestindo um boné do MST (ou como propõe o grupo na rubrica de sua dramaturgia, fazendo referência a alguma outra luta atual), o personagem encerra a cena lembrando que o campo segue aberto para novas tentativas.

A interferência de Olho Vivo é responsável por explicitar o jogo teatral que está em curso. Ressaltando que o público é participante das cenas e precisa tomar parte, o Coringa evidencia uma outra dimensão da coralidade presente no espetáculo, diversa da representada pelo "Coro de Corintianos". O encontro composto pelo público e pelos artistas, ou seja, a coletividade artística, compõe uma outra possibilidade de agrupamento, uma coralidade com pressupostos críticos e ativa, que comporta a consciência histórica do processo e as contradições internas a cada um dos tipos e figuras representados.

A partir daí, experiências de mobilização política contemporâneas, sobretudo pelo viés da cultura, vão sendo recolocadas pela encenação da Brava Companhia. Principalmente por se tratar de um dos grupos que mais investiga caminhos nesse sentido, sua prática artística busca relacionar-se de maneira vigorosa tanto com o movimento teatral, quanto com organizações políticas e culturais diversas, o que os leva a sintetizar criticamente, em Corinthians, meu amor - segundo Brava Companhia, alguns dos impasses vivenciados pelos movimentos. Somando-se a isso, por meio da 
perspectiva histórica e coletivizante adotada pelo Coringa Olho Vivo passamos a ver na cena não mais impasses que dizem respeito apenas à produção da Brava Companhia ou dos tipos representados, mas sim um impasse relativo a todo um momento de crise da produção artística com viés de esquerda, e que tem perspectiva de atuar de forma militante.

\subsection{Valor coletivo e forma popular}

A importância do ponto de vista de Olho Vivo para a encenação da Brava Companhia transcende o seu valor histórico como homenagem ao grupo ou a uma produção de esquerda que marcou a tradição teatral nacional. O interesse em representar os personagens populares por meio de um olhar engajado com as questões de classe diz respeito, também, a características particulares da constituição do cânone literário nacional desde os esforços modernistas da formação. $O$ entrave do analfabetismo estrutural, da não consolidação de um sistema literário no qual a população pudesse transitar ativamente, e, por outro lado, a imanência, antropológica, de uma intensa atividade cultural por parte das camadas marginalizadas, todos esses pontos nunca foram ignorados pela produção artística nacional, sendo responsáveis por seus maiores ganhos formais e críticos.

Todavia, as formas encontradas para lidar com esse impasse variam substancialmente. Como já descrevemos acima, a peça toma como ponto de vista a prática do grupo Teatro Popular União e Olho Vivo e alguns dos seus pressupostos estéticos e políticos para interpretar a produção cultural contemporânea. Antes mesmo que a cena final tenha início, a Brava Companhia se despede do personagem Olho Vivo, resgatando, com esse gesto, o aspecto de homenagem ao grupo e sua importância, e também reforçando a imagem coletivizante de muitos olhos vivos:

Aprendo sempre com esse negócio de tentar entender a regra, furar os bloqueios, sabe comé? Olho Vivo! Fazendo referência ao próprio personagem e ao grupo Teatro União e Olho Vivo. A todos os olhos vivos, abertos! Nesse mundo estamos tentando celebrar as luzes e denunciar as sombras. Estamos tentando... e mais dia menos dia, virá a partida, o grande embate... eu sei que virá (BRAVA COMPANHIA, 2015, p. 242). 
A abordagem por meio da qual o grupo se aproxima do texto original deixa explícito o fato de que "olho vivo" não é apenas um nome, mas também uma frase imperativa, uma bandeira de luta que emerge do Teatro Popular União e Olho Vivo, e que consiste em um modo de olhar criticamente para a cultura, buscando ao mesmo tempo "celebrar as luzes e denunciar as sombras" (BRAVA COMPANHIA, 2015, p. 242). Esse aspecto, que remonta à possibilidade de uma relação ambivalente com os materiais populares (desde que se mantenha a denúncia e a atitude crítica, a interação com suas formas poderia ser empreendida de maneira positiva), exige correções, de tempo em tempo, à luz das transformações efetivas do campo material, que entende a cultura como algo vivo.

Nesse sentido, compreender a maneira como o Teatro Popular União e Olho Vivo se aproxima dos materiais populares para consolidar suas proposições estéticas, bem como reconhecer em Corinthians, meu amor - segundo Brava Companhia uma novidade formal que, quando comparada às outras peças da companhia, aponta para essa dimensão coletivizante do espetáculo teatral, é também reconhecer um traço de resistência profundamente enraizado às práticas populares, ainda que intimamente imbricado com aspectos regressivos. A relação proposta entre obra teatral e público em espetáculos como Julio e Aderaldo ou Este lado é para cima nos permite observar que há uma atenção particular destinada pela Brava Companhia às dinâmicas relacionais que antecedem o acontecimento teatral. Nesse sentido a peça opera como uma intervenção em um sistema de signos que a antecede, e estrutura-se a partir dessa fricção, tencionando uma sociabilidade previamente institucionalizada.

Nesse sentido, às duas camadas de apreciação propostas pelo nosso Coringa Olho Vivo, que articulam elementos épicos e dramáticos na construção da narrativa, soma-se uma terceira camada de apreciação, de fundo popular, que concerne ao acontecimento em si e às inúmeras possibilidades que advém do puro encontro dos corpos no espaço, a qual chamaremos aqui de camada performativa. Mais uma vez, reconhecer a inefabilidade de corpos completamente livres para quaisquer experiências é reconhecer também os limites do princípio performativo como prática estilística em sua pureza. No caso do teatro, tal princípio exige, por conseguinte, uma correção que tem por base uma atitude dramática ou épica para se consolidar como linguagem: 
Essa proposta de espaço e ambiente tem origem na vontade e intenção de manter os espectadores próximos, sem divisão entre público e atores, sem delimitação hermética do "espaço cênico". Esse jogo visto de dentro, ouvido e tocado de dentro, cheirado de dentro, busca contrariar a relação espetacular da nossa sociedade com a arte e os esportes e, assim, é organizado para ser vivido junto, compartilhado, e não apenas visto de longe. Busca a construção de um espaço de relações horizontais, agregador, de encontro, de festa e até de farra ${ }^{16}$.

O que nos parece substancial nessa divisão em camadas é o esforço de tornar explícita a estrutura de produção que engendra o todo da obra. Ao gerar uma proximidade entre todos os participantes, sugerindo um acontecimento cultural que transcende a dimensão do objeto de arte, a Brava Companhia cria uma falsa indistinção entre espetáculo e vida real, com a qual o público se identifica empaticamente. Esse material é trabalhado para que possamos entrever distintas formas de representação do popular, que por vezes obnubilam a percepção da realidade comum partilhada por meio da experiência material.

Ainda que o objetivo de ocultar as hierarquias, criando uma relação horizontal com o acontecimento teatral, mostre-se contraditoriamente presente, o intento se relaciona diretamente com as expectativas políticas do grupo e com a cena cultural gestada na periferia das cidades. A expectativa de formação de público e de inclusão dessa população em um sistema cultural pressupõe um confronto com a dimensão hierárquica proclamada pela cultura hegemônica, de modo que os espectadores sintamse parte dessa produção. O desejo de produzir uma coletividade, de mobilizar politicamente corpos e pensamentos para uma prática transformadora se faz em gesto, como proposição estética e formal. Ao mesmo tempo, por se tratar de um trabalho de caráter épico e historicizante, esse teatro distancia o interlocutor e demanda a interpretação dos fatos apresentados pelo grupo ao inscrever a peça na história do teatro popular e na periferia. Tal movimento revela impasses vividos por essa produção cultural e estabelece com ela nexos políticos e sociais que determinam sobremaneira o curso da representação. Desse modo, essa camada que chamamos de performativa produz as camadas épicas e dramáticas na constituição da narrativa, ao mesmo tempo em que indica um espaço externo à representação, que remete à própria prática da Brava Companhia junto à sua comunidade e às práticas de outros coletivos culturais

16 Texto do release da peça, fornecido pela Brava Companhia. 
na cidade de São Paulo. Em certo sentido, é também a performatividade própria da ação cultural e da estrutura espetacular, aprendida e apreendida na vivência social comum, ou seja, na esfera pública, que se transforma em suporte para o acontecimento teatral.

O Boteco do Olho Vivo - espaço criado pela Brava Companhia dentro do Sacolão das Artes - expande suas dimensões semânticas. O lugar é tanto o espaço cênico, "onde evoluem os atores e o pessoal técnico: a área de representação propriamente dita e seus prolongamentos" (PAVIS, 2008, p. 142), como também é o espaço dramático, contendo "indicações sobre o lugar fictício, as personagens e a história contada" (PAVIS, 2008, p. 143). Além disso, imbricado com sua dimensão estética, o lugar em si onde a peça é representada ${ }^{17}$ carrega também significados políticos, seja para a população do bairro, seja para o público que visita o galpão pela primeira vez, o que faz com que, semanticamente, ele esteja longe de se esconder do espectador, como uma caixa preta em sua pretensa neutralidade.

A maior parte das apresentações da peça deu-se dentro de circuitos de teatro vinculados a essa perspectiva militante, como escolas, sedes de grupos parceiros ou mostras de teatro com temática política, como foi o caso das apresentações feitas no CCSP, em um evento de memória aos 50 anos do golpe militar. Nesse sentido, a hipótese de que o valor público e coletivo do espaço que recebe a peça é um elemento que faz parte do acontecimento estético corresponde, em grande medida, à opção de circulação de Corinthians, meu amor-segundo a Brava Companhia. Para a técnica "Robin Hood" o grupo recorre geralmente a outros espetáculos, como A Brava ou Este lado é para cima, produzidos para a rua e com formas bastante distintas das que analisamos aqui, ainda que de igual valor formal.

Nesse sentido, além de interpretarmos a dimensão espacial implicada pela cena, somos obrigados a interpretar o acontecimento cultural em curso a partir de suas

${ }^{17}$ A maior parte das apresentações da peça deu-se dentro de circuitos de teatro vinculados a essa perspectiva militante, como escolas, sedes de grupos parceiros, ou mostras de teatro com temática política, como foi o caso das apresentações feitas no CCSP. Nesse sentido, a hipótese de que o valor público e coletivo do espaço que recebe a peça é um elemento que faz parte do acontecimento estético corresponde, em grande medida, à opção da companhia nesse momento. Para a técnica "Robin Hood" o grupo recorre geralmente a outros espetáculos, produzidos para a rua e com formas bastante distintas das que analisamos aqui. 
diversas dimensões e de todo um movimento cultural da periferia composto por saraus, pancadões, festas de rua, grafite, rodas de samba e associações comunitárias.

Essa exigência não é um pressuposto que concerne a toda e qualquer obra teatral, e apenas se torna procedimento formal dada sua relação intrínseca com os outros elementos da cena e com o projeto político do grupo. A sobreposição de significados é ressaltada na medida em que Olho Vivo leva a coexistirem ali artistas e público, de maneira singular. Não é apenas uma "quebra da quarta parede" na interlocução entre atores e público que fica sugerida nessa nova configuração, mas também a convocatória que se estende sobre seus corpos e sobre sua atenção crítica, fazendo com que todos os presentes passem a ocupar as mais diversas funções, seja como atores - assumindo papéis dentro de cena -, seja como público. Com isso, o artifício formal provoca o espectador no sentido de que todos os participantes da encenação devem ser igualmente "lidos" para a compreensão de todos os nuances da situação vivenciada. Desse gesto fundamental a Brava companhia tira novas consequências de algumas propostas da teoria estética de Bertolt Brecht, buscando, dessa forma, apreender como a obra se situa dentro de suas relações de produção, pergunta essa que ressoa nos escritos de todos os autores implicados em uma estética de teatro engajado.

Ainda que não possamos concordar que Brecht entenderia o contexto sociopolítico dos movimentos culturais como propício a uma revolução, ou seja, não veria ali a possibilidade de um terreno fértil para a aplicação de suas peças didáticas, as expectativas do jovem Brecht de "extrair do instrumento de prazer um objeto didático e reformar determinadas instituições transformando-as de locais de diversão em órgãos de divulgação" (BRECHT, 2005, p. 126) parecem fazer jus ao trabalho desenvolvido pela companhia, que reconhece na diversão um importante instrumento de luta.

O locus representado, o bar, apareceria, portanto, como passível de ser reformado no sentido mais político que se possa buscar, tendo em vista a simples imagem proposta pelo autor no "Pequeno Organon para o Teatro" (BRECHT, 2005), na qual se projeta um espectador de tal modo confortável no espaço teatral, a ponto de tranquilamente acender seus cigarros e observar criticamente a cena. Em sentido mais amplo, contudo, também o Sacolão das Artes se transformaria em um espaço de diversão caso fosse apropriado pela população, posto que esse novo público não é completamente desimplicado do processo de produção da peça e poderia tomá-la para 
si, apropriando-se do espaço e construindo uma narrativa diversa. Nesse sentido, é de primeira ordem relembrar que o trabalho da Brava Companhia é permeado por atravessamentos políticos concernentes a uma realidade que ultrapassa os limites de uma pesquisa estética autocentrada. A implicação do grupo com os diversos lugares que ocupa, seja como trabalhadores da cultura precarizados, seja como artistas, militantes e moradores de periferia, determina a complexidade de tais formulações estéticas. Essa característica não pode ser ignorada, para que possam ser estabelecidos os necessários paralelos entre as proposições formais das peças didáticas (KOUDELA, 1991) de Bertolt Brecht e o trabalho da Brava Companhia.

A hipótese é de que a transformação de um locus reconhecível - onde as regras e condutas referentes àquele espaço poderiam ser de tal modo apropriadas que pudessem ser usadas em sentido crítico -, é comparável às análises do autor acerca da conduta do público de práticas esportivas, como o boxe, no sentido de que as interferências no desenrolar da narrativa e sua participação partiriam de um acordo comum entre os envolvidos. Essa conduta didática é modelar no trabalho de Brecht, o que nos leva a compreender que o método dialético de intervenção nas instituições culturais aponta não apenas para a obra, mas para aquilo que está fora dela, ou seja, sua institucionalidade, em um trabalho sistemático que se assume de maneira negativa, como atesta José Antonio Pasta (PASTA, 2010, p. 70-71). Tendo isso em vista, o sentido dado ao trabalho de Brecht por um grupo que se propõe a atuar politicamente na periferia da cidade de São Paulo, em relação direta com uma população apartada do "progresso" e que está longe de manter uma relação direta com os cânones do teatro nacional, pode indicar novas interpretações de sua obra. A partir de uma exigência de apreensão dialética da totalidade, que para Pasta (2010, p. 121-122) se apresenta na obra de Brecht, torna-se necessário que se reconheça o contexto social com o qual se dialoga para que se efetive uma nova dialética, atenta à forma e ao processo produtivo, para que um novo conteúdo e uma nova sociedade possam emergir.

A trajetória de grupo militante de esquerda, envolvido com movimentos de luta na região onde atua, é o ponto de partida para a constituição desse novo discurso acerca da mobilização política. A crítica que costumeiramente recai sobre a práxis estética e política da esquerda, que é negativamente associada a uma atitude panfletária e que, de maneira messiânica ou heroica, tentaria proclamar verdades sobre o processo de 
organização e luta social, é questionada internamente pela peça, como ponto de partida para a reflexão.

Quando a militante popular vinculada a causas de moradia tenta discursar para os trabalhadores e organizar uma luta, sendo interrompida pelo grupo de torcedores, o ponto de vista do Coringa Olho Vivo nos dá a ver que a perspectiva representada pela personagem está em vias de desaparecer da cena. A despeito de seu esforço em chamar a atenção para a relevância da fala da militante, a peça nos faz ver que até mesmo o espaço da militância teatral, tal e qual realizado durante a década de 1970, já se encontra suprimido por novas formas de repressão social e carece de novas formas se quiser sobreviver. Cabe aqui ressaltar que, por vezes, esse papel foi representado por líderes comunitários locais que estavam presentes e que estabeleciam, eles próprios, os mais variados níveis de vínculo com a Companhia anfitriã. Contudo, ainda que tais lideranças estivessem sustentadas por uma relação comunitária (externa à peça e restrita a círculos reduzidos de intervenção no imaginário coletivo), sua presença como indivíduos no curso da ficção mantém a correlação dos signos sem alterar substancialmente nossa análise. Com isso, a possibilidade de uma liderança ou de personalismo na leitura dos contextos de luta desaparece do horizonte das novas práticas organizativas. O processo representado pela Brava Companhia, portanto, elimina a possibilidade de protagonistas ou heróis.

Esse fato, que poderia apresentar apenas um breve deslizamento entre real e ficcional no curso do espetáculo, relaciona-se objetivamente com o processo de criação da obra, bem como com a sua inscrição no aparelho produtivo e com o ponto de visto histórico e crítico abarcado pelo Coringa Olho Vivo. As intenções mobilizadoras, sejam elas as da Brava Companhia, sejam as do TUOV, não se restringem à própria ficção, mas, sobretudo, estão inscritas em um aparelho mais amplo, para o qual convergem coletivos culturais periféricos, coletivos políticos (por vezes, autogestionados) e a própria atividade de organização militante nos bairros periféricos e na cidade de São Paulo. Com isso, a Brava convoca parte do processo de criação e produção dos seus espetáculos para o bojo da cena, explicitando relações sociais mais amplas, inscritas no tecido social.

A forma fragmentária do cabaré, reivindicada como estrutura narrativa e associada a uma perspectiva de teatro que reorienta a conduta do público dentro do 
corpo do espetáculo, parece sugerir uma apropriação sofisticada, ainda que distante das formas mais acabadas de elaboração dramatúrgica preconizadas por Brecht. No Boteco do Olho Vivo, a cultura cotidiana do subproletariado marginalizado torna-se o gestus a ser observado pelo público, objeto de um olhar específico para suas contradições históricas, e não apenas substrato temático ou formal, desimplicado de uma prática organizativa que procura novas possibilidades para se organizar. A ideia de um gestus coletivo de encontro festivo nesse cabaré de periferia, representa, contraditoriamente, uma rede de solidariedade mútua e uma forma de alienação e apagamento das dores e mazelas sociais experimentadas na vida social. Na mesma medida, os gestus aparecem problematizando as relações internas a esta coletividade, como pretendemos nos aprofundar nos demais capítulos dessa análise.

A dualidade entre indivíduo e coletividade que restringe as possibilidades de ação política é o ponto de partida para que possamos configurar o espaço comum que o espetáculo nos propõe. Dessa maneira, o que passamos a acompanhar são diferentes tipos sociais representados pelos atores, e um público, formado por outros tipos sociais diversos e variáveis, de acordo com o dia de apresentação. O espetáculo produz uma situação de observação mediada pela ação dos atores. As formas são diversas, indo desde a possibilidade de ter como interlocutor de um diálogo alguém do próprio público (ainda que o diálogo não se cumpra, já que raramente o público responde às interlocuções), até a possibilidade de uma cumplicidade malandra, que opera como um comentário, antes de se aproximar de um outro ator/personagem, propondo uma nova situação dramática. Por vezes, apenas a presença de um personagem ao lado de um objeto já delimita essa nova relação, ou, ainda, um comentário feito pela dramaturgia acerca da cor da roupa de alguém no público dispara uma nova situação. É, portanto, do encontro e da exposição dessa precariedade que a peça tira as consequências mais contundentes. O jogo entre atores e público é o elemento sobre o qual a peça se fundamenta, e caso o público não se implicasse no espetáculo, ele simplesmente deixaria de acontecer.

Esse movimento de idas e vindas na relação entre atores e espectadores, mesmo que convocando a participação do público, impede a ficção de se completar em ilusionismo. Tendo por origem a tradição épico-dialética de Brecht, o procedimento distancia e causa estranhamento no espectador por meio do movimento das cenas, 
desestabilizando-o e obrigando-o a perceber seu corpo e sua presença em ato; inscreveo no espetáculo, mas sem convocar a sua identificação subjetiva com a representação.

A noção diversa daquilo que se entende por representação brechtiana tem origem, nesse caso, do confronto entre o teatro épico e a crítica às formas da sociedade do espetáculo tecida pelos situacionistas. O movimento entre a representação crítica e a experiência de vivência (ou situação), em prol de uma produção artística capaz de incidir diretamente sobre o campo social, suscita o movimento formal do espetáculo e abarca toda uma produção estética que ganha força, sobretudo, a partir de 1968. Não podemos nos furtar a explicitar que Boal, Guy Debord e César Vieira são pensadores conhecidos por convocarem a ação do público para o centro de seus trabalhos, o que os aproxima substancialmente das novas teorias performativas que ganhavam fôlego no mesmo período. A diferença, contudo, de caráter irrevogável, é a perspectiva política implicada em tais proposições estilísticas, que pressupõem a apropriação dos meios de produção e sua refuncionalização com o desafio de "não abastecer o aparelho de produção, sem o modificar, na medida do possível, num sentido" (BENJAMIN, 2012).

Com isso, novamente nos envolvemos com as proposições estéticas do grupo Teatro Popular União e Olho Vivo, como parte dessa coletividade artística implicada com a transformação efetiva do campo social. César Vieira afirma com veemência que é nas formas próprias à sociabilidade e cultura dos populares que o artista, muitas vezes ele mesmo um popular, busca e encontra as formas de seu teatro, sejam elas estéticas ou em nível organizacional. $\mathrm{O}$ paralelo que estabelece com os times de futebol de várzea e com a capoeira (VIEIRA, 2007) fornece a exata dimensão do tratamento dado aos materiais populares diversificados sobre os quais se debruça, mantendo sempre os olhos atentos às formas pelas quais a cultura popular resiste a despeito de tantas ações repressivas.

Sendo assim, os espetáculos apresentam recursos formais que dialogam com estruturas populares e a partir daí articulam uma nova perspectiva de abordagem. Como observa Antonio Candido, a maneira como o espetáculo Revolta da Chibata "dispunha em quadros sucessivos segundo um ritmo de vaivém no tempo, de maneira a modular uma espécie de grande parada histórica anticonvecional" (CÂNDIDO, 2007, p. 37) fundava uma relação diversa com a "história oficial", cumprindo uma função temática e formal ao alojar o levante de marinheiros no imaginário histórico do público. Em 
Corinthians, meu amor - segundo Brava Companhia o mesmo princípio pode ser observado visando um novo significado para o boteco. Tendo em vista que o bar é um dos poucos ambientes de encontro na sociabilidade periférica e que parte significativa de sua produção cultural passa por esse locus, a noção política desse espaço de convívio traz implicações substanciais para o encaminhamento da dramaturgia. Muito embora a investigação formal tenha como base tais pressupostos,

[...] o cotidiano não pode ser pensado como um lugar mítico onde, em sua pureza, os pobres se apresentam como são, libertos de ideologias estranhas. Melhor vê-lo em sua ambiguidade de "conformismo e resistência", expresso na consciência fragmentada da cultura popular (SADER, 1988, p. 141).

Tendo isso em vista, o estudo do gestus de cada um dos personagens, bem como a apreensão do convívio popular mediado pelo boteco, é central para capturarmos o processo social representado. Soma-se a isso um tipo de interlocução direta entre atores e público que propõe um novo acordo entre palco e plateia, tendo por base o engajamento de todos nessa construção comum e retomando o autonomismo presente na autoconstrução que gestou grande parte das periferias da cidade de São Paulo.

\subsection{Mobilização coletiva e a coralidade do público}

Um dos problemas centrais à peça, e de difícil captura, está em identificar quem são esses sujeitos históricos que já não mais se reconhecem como trabalhadores, tampouco se reconhecem como cidadãos ou em posse de seus direitos básicos de cidadania, como acesso à cidade, emprego, mobilidade, etc. Encontrando, por sua vez, subterfúgios externos para se reconhecerem em comunidade como times de futebol, igrejas, nichos culturais e intelectuais, a principal pista que nos traz o espetáculo vai em sentido oposto, e está no reconhecimento da dimensão da territorialidade como uma tentativa, ainda que precária, de estimular uma identidade de classes por meio de um processo efetivamente material. Com isso, a peça, diferentemente da versão original, circunscreve-se toda a um só ambiente periférico (extremamente reduzido por ser apenas o espaço de um bar), e apenas se projeta para além dele a partir das relações que estabelece com o público e com o movimento teatral. 
À luz de alguns apontamentos sugeridos por Paulo Arantes (2014) no que se refere à análise das jornadas de junho de 2013 no Brasil - "Depois de junho a paz será total”, publicada no livro O novo tempo do mundo, de 2014 -, destacamos uma nova noção de cidadania que se formou durante o processo de resistência à ditadura e abertura democrática no Brasil. Chamada pelo autor de "cidadania insurgente", essa ideia advém das práticas que formaram, ao longo das quatro últimas décadas, as periferias da cidade, por meio de mutirões e práticas coletivistas fornecendo

[...] o contexto e a substância de uma nova cidadania urbana [...] fruto de uma insurgência local que desestabilizou os privilegiados a partir dos lugares históricos da diferenciação igualitária - os direitos políticos, o acesso à terra, a igualdade, o servilismo. Como se está percebendo, o nervo dessa insurgência - inusitada apenas no emprego inesperado da palavra - é urbano, e graças a ela os trabalhadores pobres garantiram nada mais nada menos que o seu direito à cidade, hoje no epicentro da convulsão social que se sabe (ARANTES, 2014).

Assim, a opção formal por representar o boteco do Olho Vivo para lançar luz sobre um outro tempo da organização política das periferias, pautada por ações insurgentes que fizeram frente ao Estado e à propriedade, mostra-se como resquício de um ativismo político de outra ordem e vislumbra a potência desse espírito coletivista e popular extraoficial, ainda que rebaixado e circunscrito a um único ambiente. Nesse sentido, sua representação é ambivalente dado o caráter paródico com que critica a sua própria institucionalização por meio da representação de seus limites, ao mesmo tempo que uma sociabilidade diversa se produz no interior do espetáculo. A representação tipificada das figuras, com um tratamento cômico que beira o grotesco, é a forma encontrada pela Brava Companhia para questionar uma prática social familiar e comum na sociabilidade do próprio grupo sem recair em uma atitude moral que veria naquelas mesmas práticas populares fundamentos unicamente regressivos.

Por conseguinte, é a partir dessa relação formalmente coletivista que começamos a observar as contradições de cada um dos personagens e vislumbramos uma estrutura organizativa que dá conta do todo do espetáculo. À medida que a peça se desenrola, os personagens, por intermédio da força gestual, ganham mais nuances e passam a desenhar um todo mais complexo, que não se dá a partir do mergulho subjetivo nas figuras, mas, pelo contrário, vem da apreensão das suas relações diante de um todo mais 
complexo. Essa atitude formal se estende à relação com o público, como consequência das definições cenográficas, e também determina os encaminhamentos dramatúrgicos.

Também no que se refere ao papel desempenhado pelo nosso Coringa Olho Vivo podemos apreender esse novo lugar de interlocução da cena. Ainda que o personagem nos apresente as regras do jogo e oriente o nosso ponto de vista com relação à narrativa, ele deixa de ser o responsável pela unidade do espetáculo. Sendo assim, as falas de todos os personagens são direcionadas aos espectadores (não apenas as do Coringa e tampouco apenas de maneira narrativa), inscrevendo o público na situação dramática e convocando-o a tomar parte para, possivelmente, mudar o rumo das cenas. Essa abertura, por sua vez, não prescreve efetivamente a obrigatoriedade de uma ação interna ao espetáculo por parte do espectador, ação essa na qual ele deveria se engajar para o andamento da cena; antes, reconhece que está nas respostas que por ele possam ser dadas a transformação efetiva da situação representada, bem como a transformação desse locus em espaço político.

$\mathrm{Na}$ cena de apresentação, Olho Vivo descreve cada um dos tipos que serão representados pelo espetáculo. O Coringa alerta também aos presentes no público para o fato de que "todos nós, vocês também são personagens atuantes desse nosso encontro. Que hoje, aqui, o que tiver que ser feito, seja feito" (BRAVA COMPANHIA, 2015, p.272). Não à toa, a primeira apresentação, a de Marcito, explicita a regra e o procedimento que será adotado no curso de todo o espetáculo, ressaltando, em tom de flerte com uma espectadora, que ela tem o perfil para participar do seu novo clipe. Nesse gestus, o personagem nos dá a ver que a mesma apreensão externa por meio da qual os atores constroem seus tipos sociais se estenderá à participação provocada no público.

\footnotetext{
“Olá, que olhos, heim? ... Eu estava te olhando ali de longe... deixa cair uma chave. Nossa! Caiu a chave do meu carro! ... joga achave para longe ... caem outras chaves. Caiu a chave da minha moto! Para Atílio. Estaciona lá a minha Kawasaki! Cai outra chave. A chave do meu apartamento na Paulista! Para Atílio. Estaciona lá pra mim! Estava te olhando de longe e pensei: eu e você, você e eu ... Meu nome Marcito, 97442-8092, o Ferinha do Parque Santo Antonio" (BRAVA COMPANHIA, 2015, p. 206). ${ }^{18}$
}

\footnotetext{
${ }^{18}$ Notar que na primeira versão da dramaturgia, cedida pela companhia à pesquisadora, há maiores evidências que corroboram para considerarmos a autopromoção e o convite para o vídeoclip como gestus do personagem.
} 
Produzindo uma distância imprescindível para o exercício da crítica, o estilo de representação, que sugere um realismo grotesco, preserva a subjetividade de todos os presentes intacta, permitindo que a peça possa agir com acidez de alta voltagem para explicitar as relações sociais em curso e se debruçar de maneira uniforme sobre todos. Com isso, à medida que passamos a acompanhar as diversas interações entre os atores, e entre os atores e o público, aos poucos apreendemos que é a partir da leitura gestual da representação que tiraremos suas maiores consequências críticas.

Ainda que a situação dramática se consolide inteiramente e inclua o público, esse movimento de idas e vindas na relação entre atores e espectadores impede a ficção de se completar em ilusionismo. Tendo por origem a tradição épico-dialética, o procedimento distancia e estranha o espectador por meio do movimento das cenas. A noção distinta daquilo que se entende por representação brechtiana surge, contudo, do confronto entre o teatro épico e essa cena situacional que envolve e convoca o espectador.

Em Brecht, e nesse seu remoto modelo, é a perspectiva de futuro, o produzirse de algo novo que permite chamar à copresença (presentificação e simultaneidade) os sistemas do passado. O seu fazer-se pede que, ante nossos olhos, eles se tornam simultâneos e descrevam suas revoluções recíprocas. Este seu a-presentar-se como que os lega, em conjunto, àquele que deve produzir o novo e, nisto, são o patamar de sua capacidade de ação.

Brecht, ele mesmo, utilizou uma imagem reveladora, no próprio A compra do Latão: distinguindo entre dois tipos de teatro (distinção que ele antecipadamente adverte precária e provisória), chamou ao teatro que mais o interessa "Tipo P", isto é, de "Planetário". Ao "tipo P" ele opõe o "tipo C", de "Carrossel," [...] No "Carrossel" Brecht vê a busca da sensação de mundo pelo mergulho num mundo fictício. No "Planetário" o que se dá a ver é o movimento dos astros, tanto quanto nos são conhecidos, sendo o fictício aí a correção excessiva de suas elipses e círculos perfeitos [que] não reproduzem senão imperfeitamente os seus movimentos reais, porque, como sabemos, são mais irregulares.

Em ambos, a presença do elemento "fictício"e o impulso de fazer-se mundo (PASTA, 2010, p. 140-141).

Os movimentos "Carrossel" e "Planetário", conforme designados por Brecht, misturam-se organicamente de tal modo que estabelecem um fluxo entre a representação crítica inscrita no espetáculo e a crítica à sociedade do espetáculo, nos termos de Debord (DEBORD, 1997). O contraponto formal a Brecht poderia apontar para um diálogo com proposições situacionistas, configurando o movimento total do espetáculo, que aparece entre os autores de referência para o grupo em diversos momentos nos Cadernos de Erros da Brava Companhia. Todavia, a correção dialética à 
proposição conceitual de Brecht apenas é possível a partir da propria noção proclamada por ele mesmo de representar-se um sistema real, tal e qual ele é conhecido. Tendo isso em vista o público não poderia ser ignorado do sistema representado pela peça.

Nessa medida, o jogo proposto pelo grupo envolve e implica os espectadores no espetáculo. A paleta de ações de alguns personagens passa a interagir com o público, que atribui significados distintos aos gestos representados e reage aos acontecimentos de maneira física. As regras desse jogo são evidenciadas por meio de uma ficção e possuem um conteúdo autocrítico, o que também implica que, dado o grotesco e o ridículo, os personagens não sejam preservados, sendo antes autodestrutivos e nem um pouco modelares, o que nos impede de dotá-los de um ideário heroicizante. Por outro lado, o gesto coletivo proposto pela peça - de observarmos e vivenciarmos a configuração complexa e diversificada de um corpo social, reproduzido pela estrutura formal da obra -, leva a uma reflexão acerca das dificuldades de organização política que tem por base a experiência dos espectadores. Dialeticamente, a forma é quem propõe a regra, mas esta só se torna possível diante de um conteúdo crítico que não produza uma identificação subjetiva, mas sim histórica com o conteúdo.

A partir desse procedimento, diversas cenas se desenrolam, estabelecendo diferentes níveis de contato com o problema central. A peça dedica-se especialmente a demonstrar em que os personagens se diferenciam uns dos outros, posto que a copresença na situação proposta já produz aquela pretensa convergência entre as ações. Essa escolha nos possibilita, como espectadores, observar as particularidades de cada um dos tipos representados, e nos leva a identificarmo-nos, parcialmente, apenas com os gestus representados, nunca de maneira subjetiva. Aos poucos passamos a nos ver em fragmentos gestuais de todos os personagens, tornando-nos, nós mesmos, personagens a serem investigados enquanto passamos a observar a reação dos outros espectadores, que passam a compor a ordem da representação, transformando-se em signos diante dos nossos olhos. A implicação da presença e da imaginação política constitui, nesse momento, o substrato a partir do qual o espetáculo começa a tecer novos significados.

Uma vez que essa copresença é engendrada entre todos os presentes, aqueles que estão dispostos nas mesas do bar se transformam aos olhares dos outros espectadores em atores, ainda que não sejam convocados a agir. As atitudes de cada um dos presentes, por sua vez, compõem a cena vista pelos demais: seja nos risos (que por 
vezes irrompem em gargalhadas e adquirem até tons excessivos), seja nos comentários que correm soltos ao longo da peça, seja nas reações às situações ou no desconforto dos bancos plásticos, seja na presença de crianças que simplesmente rompem todo e qualquer limite da etiqueta teatral e começam a dançar e cantar uma canção junto com a cena, todos os presentes veem e são vistos na mesma medida ${ }^{19}$. Com isso, o caráter situacional é reforçado e a partir dele emana a fruição do todo proposto pela peça. Podemos intuir, consequentemente, que até mesmo a escolha do interlocutor para as falas proferidas pelos atores tem como base esse olhar atento à reação do público, incorporando suas reações à dramaturgia do espetáculo.

Compreender, portanto, o olhar do público para o espetáculo como uma ação implicada apenas é possível se reconhecermos que o nosso Coringa, Olho Vivo, nos convoca a essa atitude a todo o momento, propondo um pacto de atitude crítica com relação ao que se vê. Dessa forma, o olhar para a história narrada por Olho Vivo apenas é possível se entendermos também o ato da observação como ação ativa e parte fundamental da estruturação das cenas, assim como o olhar crítico para a coletividade cultural que se forma, em ato, no curso do espetáculo, tem implicações políticas para a cena contemporânea.

\footnotetext{
${ }^{19}$ Em uma das apresentações, durante a execução de uma música que projetava imagens de uma luta por um mundo mais igualitário e justo, algumas crianças, absortas pelo espetáculo, saíram de seus lugares e começaram a cantar e dançar, durante a cena, a letra da canção. A imaginação política da autora que vos escreve nesse momento voou 20 anos, pressupondo que essas crianças, adultas, ao rememorar uma canção de infância, teriam esta, não qualquer outra canção em suas memórias, e seria com esta, e não com outra canção qualquer, que essas crianças participariam dos espetáculos vindouros.
} 


\section{A paródia da unidade popular}

Como já descrevemos, o grupo nos convoca a participar do espetáculo. Sentados em um bar de periferia, nós somos a obra: vivenciamos aquilo que contemplamos, o que poderia sugerir não uma visão crítica dessa experiência, mas a reiteração do encontro transformado em espetáculo. Se o grupo recebeu a todos de maneira calorosa e aberta em seu Boteco do Olho Vivo, as contradições (possíveis) dessa proposta também se mostram de forma latente. Conforme descreve Maria Rita Kehl, em Videologias, o espetáculo se inscreve na nossa sociabilidade como forma de subjetivação que separa capital e vida material, produzindo indivíduos em série conforme passamos a depender dele para "confirmar que existimos e para nos orientar em meio a nossos semelhantes" (BUCCI; KEHL, 2004, p. 50).

A sociedade do espetáculo, que para Guy Debord é um estágio avançado da indústria cultural, transforma a todos em imagens de si mesmos, de modo a identificarmo-nos com elas na mesma medida em que o espetáculo produz a subjetividade necessária para que nos impliquemos nele. Daí que a empatia promovida pelo encontro no boteco durante a primeira cena, "Concentração", exija ser estranhada para que atinja o objetivo de proporcionar uma apreensão crítica do espetáculo.

Tendo isso em vista, a cena "Preleção" nos apresenta uma segunda camada de apreciação da obra e cumpre a função anunciada pelo nome ao explicar para todos os presentes quais serão as regras do jogo teatral proposto. No futebol, a preleção é o momento que antecede a entrada dos jogadores em campo, quando é apresentada a escalação e a estratégia que será adotada pelos jogadores. A "alienação do espectador em favor do objeto contemplado" (KEHL, 2007. p. 51), ou seja, a falta de consciência acerca das regras que orientam a sua participação no espetáculo subjaz como questão central, já que "os que sucumbem à ideologia são exatamente os que ocultam a contradição, em vez de acolhê-la na consciência de sua própria produção".

Tendo isso em vista, o movimento de promover a incorporação do espectador pelo espetáculo para, na sequência, distanciá-lo, expondo a realidade espetacular do acontecimento teatral, permite que observemos a contradição de, ao mesmo tempo, tal acontecimento ser espetacularizado, transformado em fetiche, e atuar contra o espetáculo a partir de uma ação interna a ele próprio. 
Na cena, a Brava Companhia se reúne em uma roda no centro do espaço cênico para um abraço, remetendo aos que antecedem uma partida de futebol de um time de várzea. Respeitando o formato de coro e corifeu, o grupo realiza uma oração que nos apresenta os lemas do grupo. Ainda que aludindo a um possível "culto religioso", de alguma forma ali é colocada em xeque a pertinência daquele conteúdo para os espectadores, posto que este é capturado em imagem sem que aqueles sejam obrigados a participar da enunciação.

A temática religiosa aparece no texto original de diferentes formas, em cenas que remetem aos festejos de finados, casórios, ou ainda na presença de padres que compõem o corpo social representado por Cesar Vieira. A religiosidade, profundamente imbricada à sociabilidade popular das décadas de 1960 e 1970, é tida por Cesar Vieira em sua onipresença na vida política nacional, e representada sempre em relação a outros agentes sociais. Na peça da Brava Companhia, a questão aparece sempre problematizada, contrapondo-se a dimensão do fetiche à coletividade instaurada pelas práticas religiosas, o que implica em reconhecer criticamente a relevância dessas práticas como forma social em diferentes campos.

A passagem, portanto, tenta nos introduzir às condições da prática teatral proposta pela Brava Companhia e, embora não narre a trajetória do grupo, explicita sua identidade com o bairro, com o ponto de vista periférico e com a narrativa popular e de classes:

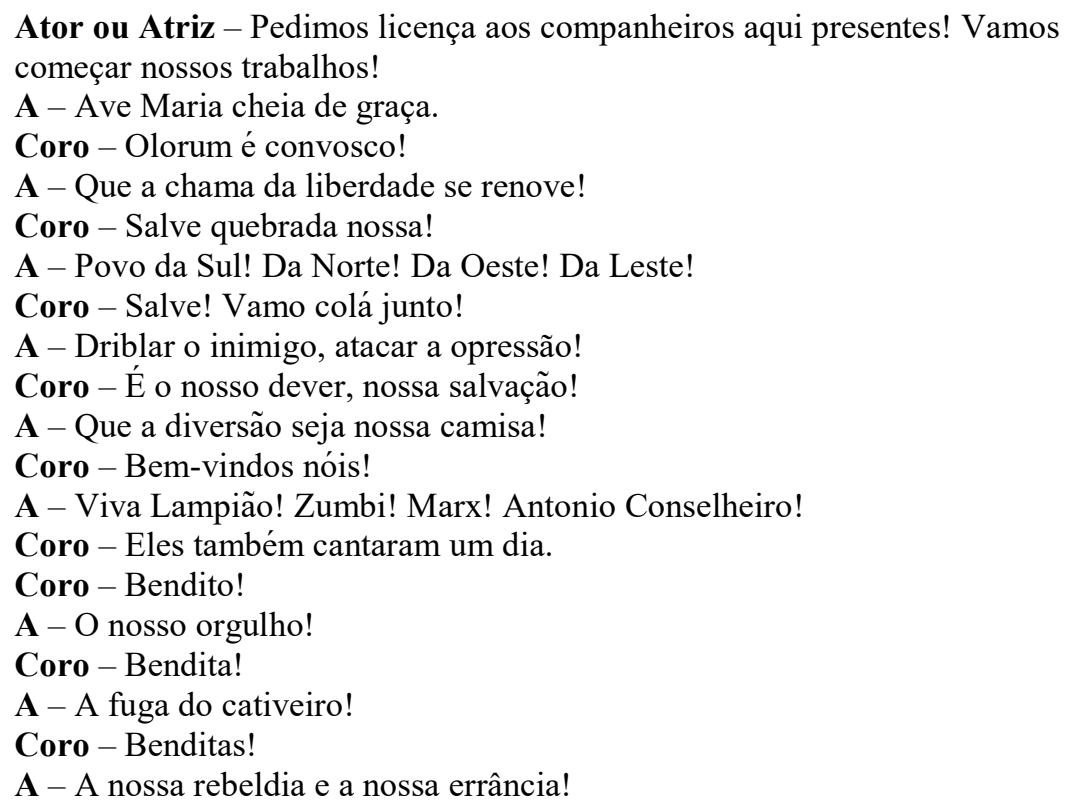




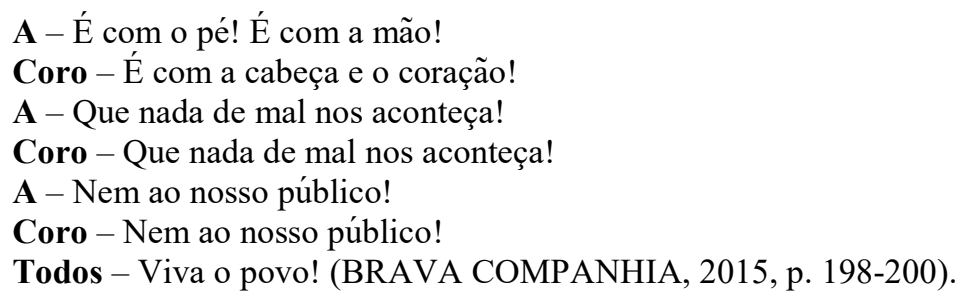

Ao recorrer à paródia de um rito religioso - em que a cada verso dito pelo "Corifeu A" recebemos uma resposta vinda do coro -, o grupo apresenta um passo-apasso de sua pesquisa estética, que nos indica as regras da contraimagem por meio do qual se organiza o jogo cênico proposto pela Brava Companhia. Formulado a partir de estudos aprofundados de A Sociedade do espetáculo, de Guy Debord (1997), o grupo vem estabelecendo uma investigação prática sobre o procedimento de apropriação de imagens do mundo do espetáculo com o intuito de produzir leituras críticas resultantes de tais estudos. Parte-se do princípio de que, ao se apropriar criticamente de imagens produzidas e naturalizadas pelo capitalismo e propor, com base no estudo minucioso destas, uma segunda imagem contrária à primeira, o grupo atingiria a dialética na formulação das cenas. Esse procedimento remonta ao trabalho de Brecht, na medida em que o autor toma das formas canônicas o modelo para uma reeducação estética e política, ao mesmo tempo que as contrapõe a formas populares de cunho rebaixado. Vinicius Pastorelli (2014) observa que no primeiro livro de poemas do dramaturgo o procedimento já vigorava em sua investigação estilística, apontando, ainda, para o fato de que, na obra poética do jovem Brecht, temos uma imitação dos livros litúrgicos protestantes como o registro de um gesto que, parodiado, carrega em si um movimento que lhe contradiz:

[...] o que havia no livro eram baladas, hinos religiosos, crônicas históricas, relatos, conselhos. Formas arcaicas de lírica, que, recuperadas de uma tradição de que os centros urbanos estavam afastados, pelo próprio contato com as experiências modernas de 1926 geravam uma estranha impressão. [...] A mesma introdução que registrava as indicações musicais e fornecia informações sobre o contexto 'real' dos poemas fazia enfim questão de lembrar ao leitor, levando 'a sério' a indicação prática do livro, que cada leitura do manual deveria se encerrar com o hoje famoso "Contra o engano". Um poema - ou seria melhor dizer 'prédica' - que, imitando a dicção de um ministro, invertia o chamado à comunhão (PASTORELLI, 2014, p. 31-32).

O "Contra o engano" que encerraria a paródia litúrgica nos poemas de Brecht pode ser tomado como centro operacional do procedimento proposto pela Brava 
Companhia. Por meio da seleção de imagens precisas e naturalizadas que conduzam a um caminho de reconhecimento da imagem apresentada, o grupo propõe sua reformulação a partir de um contraponto, uma nova imagem que contradiga a primeira e que, somada a ela, possa apresentar a crítica da imagem na própria imagem. Entendendo-se que "o poder de sedução da imagem espetacular realiza-se no fetiche" (KEHL, 2007. p. 56), ou seja, no apagamento das suas reais condições de produção. Esse processo, compreendido por Brecht como a naturalização de uma relação social que, para ele, oculta o processo histórico, apenas pode ser contraposto por uma ação historicizante que lhe faça frente. Ou seja, o recurso da contraimagem empregado pela Brava Companhia, apresenta a imagem fetichizada sobreposta ao seu desejo fundamental (KEHL, 2007), que a antecede historicamente. Este, a partir desse momento, passa a se mostrar pervertido, como engano, expondo sua contradição.

Nesse sentido, a relação entre as duas primeiras cenas expõe o desejo de participação, identificação e comunhão para, na sequência, separar drasticamente espectador e atores. No momento da separação, os atores revelam o limite imposto para que o público realmente participe daquele agrupamento, estabelecendo, ainda, um "contraengano" à possibilidade de participar desse agrupamento de maneira mitificada, posto que a entonação de culto religioso sabota o conteúdo da cena e revela sua dimensão excludente.

Assim, o grupo nos introduz a um jogo de referências - que vai se montando em frente aos nossos olhos - por meio de releituras de teatralidades diversas e de modelos que podem ter origem seja na cultura periférica, seja na indústria cultural ou no cânone nacional, com base, sobretudo, na tradição crítica. A relação com o trabalho do antecessor e homenageado Teatro Popular União e Olho Vivo configura-se a partir desse princípio e reflete o valor coletivo da produção artística, através do recurso paródico que, para José Antonio Pasta está na base do projeto clássico de Brecht (PASTA, 2010, p. 79). A Brava Companhia retoma o Corinthians, meu amor de César Vieira, como modelo no qual insere o "Contra o engano" em cada um dos impasses observados no material original, agindo diretamente sobre uma obra de outra época de modo a organizar a sua "reposição no tempo"(PASTA, 2010, p. 39).

Essa atitude implica em “definir operacionalmente o 'fazer poético' em relação às demais formas de produção social no seu desenvolvimento histórico, ou seja, abri-la 
e vinculá-la radicalmente ao movimento da história" (PASTA, 2010. p. 39). Nesse sentido, José Antonio Pasta nos sugere que entre os principais recursos utilizados por Brecht estão a paródia e a cópia, como forma "consciente de organização dos signos no interior do texto" (PASTA, 2010. p. 39). No caso da Brava Companhia, esse procedimento é estruturante, seja para apresentar as regras do jogo teatral de uma maneira didática, seja para compreender o sentido totalizante do seu trabalho, que pressupõe a ação da cultura na constituição de uma identidade de classes.

A proposta é introduzida na "preleção" de maneira simples, por meio da sobreposição de imagens aparentemente contrárias entre si. O objetivo é, como já descrevemos, não o de expor a oposição entre as imagens, mas de evidenciar a contradição entre imagem 1 e imagem 2, elucidando uma espécie de dialética entre ambas. Ao parodiar diferentes formas culturais, desde aquelas que seriam tomadas como positivas até às mais conservadoras, o grupo estimula nossa percepção crítica através de diferentes estímulos. Essa diversidade que vai compondo um tecido simbólico difuso e controverso, vai se afinando até que, por fim, o coro é capaz de soar em uníssono o brado de "viva o povo".

O que é curioso nesse movimento de cena é que o discurso vai sendo compartilhado pelo grupo, primeiro a partir da sua oposição direta, para, aos poucos, deixar a unidade transparecer a partir das diferenças que são sublinhadas pelo texto, e não apesar delas. As contradições se tornam explícitas e intrínsecas, contrapondo-se à ideia de qualquer homogeneidade entre os populares. Quando, ao final da passagem, revela-se o desejo de união entre os populares, isso apenas se dá à luz de um reconhecimento acerca de divergências que podem ser reconhecidas por todos os presentes, e nunca a despeito delas. Ave Maria é acompanhada por Olorum, ao mesmo tempo em que se opõe a ele; a chama da liberdade e o salve à quebrada nossa possibilitam entrever a libertação da periferia enquanto gueto, sem perder sua valorização como local de origem (e processo histórico); atacar a opressão, gesto violento para a liturgia, surge como salvação na própria semântica religiosa, fazendo com que as formas se misturem aos contornos profanos da luta de classes; Benditos são os errantes, Lampião, Marx, Zumbi, Antônio Conselheiro e todos aqueles que somaram na fuga do cativeiro - diferentes personagens ligados à luta popular são convocados, um bandido, um intelectual, um negro e um místico. Não há antagonismos nessa estrutura dramatúrgica, até porque, como já afirmamos anteriormente, o objetivo da montagem é 
fazer de todos os discursos objeto de análise dialética e crítica por meio da paródia desse princípio heróicizante.

O personalismo implicado na ideia de herói é contraposto pela forma religiosa que sustenta tal ideia. Ao assumir o Coringa Olho Vivo como um herói coletivo a peça se debruça sobre os processos organizativos, criando uma oposição a esse personalismo e trazendo novas possibilidades de compreensão acerca das figuras de resistência como Zumbi ou Antonio Conselheiro. O fato de que esses personagens históricos foram representados como heróis pela dramaturgia de resistência, em peças como Arena conta Zumbi (1965), de Augusto Boal, ou Arena conta Tiradentes (1967), parceria de Boal com Gianfrancesco Guarnieri, apenas reforça nossa leitura, já que à luz desses grandes nomes a Brava Companhia propõe uma narrativa em que não há heróis ou grandes feitos, mas apenas figuras marginais envolvidas em uma ação coletiva de resistência.

A paródia de distintas formas culturais transforma tudo aquilo que é ideológico nas representações em cômico ou grotesco, apontando para o estranhamento dos discursos naturalizados e incorporados pelo status quo, sejam eles referenciados na "alta cultura", na "indústria cultural" ou na "cultura popular". A exploração da contraimagem revela as contradições desse processo no que se refere às representações do "popular", posto que, em todos os ângulos, a sociedade do espetáculo reifica suas acepções. Nesse sentido, a definição de paródia encontrada em Giorgio Agamben (2007) elucida outros aspectos observados na cena. Com origem na música grega, o procedimento consiste na separação entre canto e palavra:

[...] segundo essa mais antiga acepção do termo, a paródia designa a ruptura do nexo "natural" entre a música e a linguagem, a dissolução do canto pela palavra. Ou então, pelo contrário, da palavra pelo canto. [...] O rompimento do vínculo liberta um parà, um espaço ao lado, em que se instala a prosa. Mas isso significa que a prosa literária traz em si o sinal da separação do canto. O "canto obscuro" que, segundo Cícero, se ouve no discurso em prosa (est autem etiam in dicendo quidam cantus obscurior) é, nesse sentido, um lamento pela música perdida, pelo desaparecimento do lugar natural do canto (AGAMBEM, 2007, p. 39).

Essa definição nos permite observar que a ausência da música na passagem, substituída, por sua vez, por uma entoação religiosa, perturba seu conteúdo discursivo. O canto aí não é obscuro, mas substituído pela entoação litúrgica que traz em si a separação do canto e impõe uma unidade aos contrários. A estrutura moralizante dos 
cantos religiosos, quando contraposta pelo conteúdo diversificado apresentado pelo grupo, revela o ponto de vista ideológico presente em ambos os discursos. O "salve ao povo da quebrada" convoca o "orgulho periférico" para abrir o espetáculo; ao mesmo tempo, a imagem aparece reificada e é criticada pela forma. A religiosidade aparece como moralidade, e a luta de esquerda, como abstração desvinculada do campo material, apenas heroificada. Quando lida como fragmento independente, nessa cena, o procedimento da paródia implicaria em um problema ao dificultar a diferenciação entre os enunciados. Esse risco faz parte da tentativa de "construir o novo sob o fantasma do velho" (PASTA, 2010, p. 42), fazendo uso de sistemas de linguagem que precisam ser, eles mesmos, destruídos:

[...] nos encontramos em uma situação difícil em nossas controvérsias, porque precisamos, para refutar as asserções de nossos poderosos inimigos, servir-nos de suas palavras e de seus conceitos. Isso complica até as discussões que temos entre nós. Porque ainda que disponhamos de um arsenal conceitual relativamente preciso e próprio, encontramo-nos sempre compelidos a operar com conceitos e oposições emprestados das ideologias que combatemos (PASTA, 2010, p. 42).

Daí que, na emergência de obras que conseguem, por um lado, realizar uma crítica social contundente e, por outro, criar uma noção de coletividade capaz de se contrapor à ação imediata do capital sobre a realidade social, assume-se, por vezes, um tom conclamatório de chamamento coletivo que, ambiguamente, pode operar também um discurso moralizante, idealista e romântico ao se impor como unidade no brado de "viva o povo". Tal atitude, contudo, na abertura do espetáculo, vivifica a relação do público com as contradições representadas pela peça, fortalecendo-a criticamente ao produzir um acordo entre espectadores e atores que passam a se relacionar com o espetáculo a partir dos pressupostos de uma ideia de popular por eles reconhecível. A versão paródica do culto popular - que se coloca ao lado do canto apresentado na cena da "Concentração" - revela, ao "renunciar a uma representação direta do seu objeto", que a própria ideia de popular será o alvo dessa crítica, evidenciando as diversas formas que parecem forjar essa pretensa unidade. Também nesse sentido, ao reconhecer que há o projeto de uma ação mobilizadora comum, a investigação sobre os impasses desse caminho torna-se possível. 
Com isso, o recurso da paródia se estende também à vida ordinária por meio do formato festivo de encontro popular no boteco de periferia e das demais manifestações populares que compõem as cenas. Sem qualquer cunho elevado que nos leve a tomá-la de maneira romantizada ou idealizada, a paródia seria "oposta a toda ideia de acabamento e perfeição, a toda pretensão de imutabilidade e eternidade, [necessitando manifestar-se] através de formas de expressão dinâmicas e mutáveis (proteicas), flutuantes e ativas" (Bakhtin, 2013, p. 9-10). A paródia, para nós, teria características semelhantes à carnavalização para Bakhtin, talvez dado a um ponto de contato entre seus enunciados. Nesse sentido, quando alguma precariedade presente nas formas organizativas populares se revela ativamente, mostra-se passível de transformação e sendo desmistificada, aponta para o lugar político dessas formas. A paródia, portanto, de formas sociais de poder, e não de figuras de poder, projeta uma imagem na qual não é o rei que é parodiado e atacado criticamente, mas a sociedade que sustenta o rei; portanto, ela precisa ser problematizada e criticada para que possa atacar o rei efetivamente, e não apenas simbolicamente.

Todavia, diferente da argumentação de Bakhtin, não é em sentido carnavalesco que a paródia se dá em Corinthians, meu amor - segundo Brava Companhia. Ainda que aponte, assim como sugere o autor, para a quebra das hierarquias, para a liberação das regras, para o fim dos privilégios, o que o espetáculo nos faz ver é que, contemporaneamente, essa dinâmica de exploração presente no trabalho neoliberal já foi incorporada pelos personagens por meio de diversas formas sociais que produzem subjetividades pré-moldadas. A igreja seria uma delas, mas também o futebol e a indústria cultural fazem parte do conjunto. Em diversas frentes a produção de cultura passou a ser responsável por cunhar essas subjetividades, pautada pelos pressupostos da gestão neoliberal.

Da observação atenta sobre o real, o grupo provoca os produtores de cultura à autocrítica, exigindo destes novas formulações acerca da cultura popular e da cultura periférica. Não à toa o lugar do público é erigido à primeira importância dentro do modelo formal proposto. É o olhar do público o responsável por tecer as considerações críticas e encontrar soluções para os impasses representados, posto que a peça recorre ao realismo grotesco como um elemento de distanciamento destrutivo que impede 
qualquer idealismo que pudesse resplandecer nos personagens representados, apontando para um presente e "um futuro ainda incompleto" (Bakhtin, 2013, p. 9).

A paródia, portanto, além de dividir e produzir uma dualidade entre luz e sombra, entre canto e palavra, consiste em uma dialética de movimento infinito por pressupor a destruição sem instaurar a completude do gesto. Não por acaso o recurso foi central para as proposições estéticas dos movimentos de agitprop autoativos e, para nós, indica diferenciações necessárias de serem feitas a respeito do realismo grotesco e do realismo burguês, presentes no debate acerca do trabalho de Brecht.

Para tomarmos a situação proposta pela peça a seus "espectadores" como fato a ser analisado criticamente, é necessário compreendê-la também dentro dessa perspectiva paródica, tendo em vista a representação mimética e realista dos bares que abrigam os mais diversos "encontros culturais" da cultura popular brasileira. Seja na dramaturgia, seja na literatura ou na música, talvez pela ausência de espaços públicos, talvez pela marginalidade social infligida ao poeta e ao boêmio, o boteco sempre foi ponto de encontro das tramas culturais nacionais, trazendo uma pretensa unidade a setores da sociedade que, aparentemente, não se encontram no mundo do trabalho.

Entendemos, para efeito de nosso argumento, que a oposição entre "classe artística" e trabalhador não é natural - ressaltando que o encontro desses setores dentro de experiências como as dos CPCs, do Show Opinião e do próprio trabalho do homenageado TUOV constitui-se em contrapontos à naturalização dessa ideia -, e que a "classe artística" foi historicamente associada a uma classe média branca que mantém relações diretas com a tradição cultural do mundo europeu, enquanto o "trabalhador" cumpriu diferentes funções nessa trajetória, ainda que tenha sido nessa contradição que se gestou a maior parte da produção artística nacional.

O jogo dramático proposto, que tem como centro operacional o encontro cultural no boteco de periferia, por sua vez, tem duplo sentido na peça, já que assume tanto a potência quanto a crítica a essa realidade. Trata-se, portanto, de uma revisão crítica das relações estabelecidas historicamente entre intelectualidade, "classe artística" e proletariado. O confronto se dá amparado por um movimento cultural que subsiste precisamente no ponto central dessa contradição, reconhecendo-se como "trabalhadores da cultura" e como produtores de cultura autenticamente periférica. 
Nesse sentido, o recurso ao samba como matriz musical autenticamente popular e brasileira introduz um novo impasse para a ideia de popular e às diferentes conjugações do termo. Na formação do samba podemos observar o discurso do trabalho e da malandragem se estruturando como resposta dos negros à lei que lhes concedeu a liberdade arremessando-os ao espectro de miseráveis nas cidades brasileiras do início do século XX. A situação do trabalho (ou a ausência dele) foi fundamental para sua formação e o Rio de Janeiro se tornaria a maior cidade negra fora da África, com um enorme contingente de homens "livres" do trabalho forçado, mas desamparados, desempregados, ou subempregados, para quem a vadiagem não tinha necessariamente o sentido de recusa ao trabalho, mas era antes uma condenação, como exposto por Maria Rita Kehl: "Esses homens viviam no subúrbio ou nas encostas das favelas, eram negros, mulatos e alguns brancos que se mantinham devido a 'fortes laços de solidariedade e a uma sociabilidade ainda provinciana"” (KEHL, 2012, p. 360).

A mistura dessa sociabilidade desvinculada do trabalho com a forte presença de ritos religiosos e festas profanas, mantidos a partir dos restos reprimidos de suas culturas de "origem", criou o samba, que rapidamente passou ao gosto da classe média e se destacou da tradição comunitária e da música de improviso para se tornar meio de vida. Os primeiros sambistas foram, assim, "gente miúda vivendo de pequenos serviços, de trapaças no jogo ou até mesmo da venda de sambas" (KEHL, 2012, p. 361), gente que deu corpo à primeira manifestação cultural "legitimamente brasileira". Ironicamente, a mestiçagem era reforçada pela cultura dominante através de suas relações com o Estado e com o mercado até que se instituiu o mito da "democracia racial" e, por consequência, o samba vigorou como a principal influência da cultura popular incorporada pela elite.

Por meio do histórico do samba e das relações que estabelece dentro da peça, o grupo propõe um novo olhar que o inscreve na questão periférica, racial e, principalmente, na questão de classes. Como não poderíamos deixar de observar, o recurso corresponde à expectativa da Brava Companhia de engrossar o coro das lutas sociais por intermédio da música que "fala da história e dos problemas do povo, que tem origem no povo, para o povo" 20 . Convocar o samba para a abertura do espetáculo sugere, assim, tanto a apologia do popular e de sua tradição, como também a

\footnotetext{
${ }^{20}$ Texto do release da peça, fornecido pela Brava Companhia.
} 
valorização de sua forma, em roda, pautada pela não hierarquia (formal) dos encontros "O samba pede o canto em coro [...] formas coletivas de execução" ${ }^{21}$-, propondo assim uma reflexão sobre a identidade do trabalhador produzida com a luta.

O "Canto das três raças", composição de Mauro Duarte e Paulo Cesar Pinheiro, que ficou famoso na indústria fonográfica na voz de Clara Nunes, gravado em 1974, é a música utilizada pelo grupo para finalizar a cena da "Concentração", conduzindo-nos à "Preleção", apresenta as figuras do índio, do negro e do branco, tão caras à formação do ideário de nação, unidas sob uma mesma força e produzindo um mesmo canto - o canto do "povo dessa terra" ou o canto do trabalhador. Mais do que unificar sob a força da nação um ideário de povo, seu uso revela a exploração do trabalhador, criando unidade entre os diferentes sob o jugo do trabalho. Assim, a partir do reconhecimento de uma vivência comum da situação de exploração e não apesar disso uma unidade pode começar a ser construída criticamente.

Todavia, se assumirmos o recorte temporal a que nos propusemos nessa análise, essa canção parece propor também o discurso clássico da mestiçagem que orienta a produção intelectual nacional desde os anos 30, revelando a preponderância desses encontros culturais na cultura brasileira e seus reflexos na formalização dos discursos forjados sobre a unidade nacional e democracia racial.

Com isso, o que a peça da Brava Companhia parece nos revelar sobre a produção cultural da década de 1970 diz respeito também a um contraponto feito por essa produção às perspectivas de unificação nacional. A crítica ao ideário de povo brasileiro surge pela negação da ideia de nação, aparecendo, sobretudo, no reforço paródico de seus símbolos como o índio, o negro, o samba e o futebol. Essa dimensão pode ser observada nas peças do Teatro Popular União e Olho Vivo como João Candido do Brasil: a revolta da chibata (2011), e A lenda de Tiarajú Sape, 1984, que, embora se debrucem sobre fatos históricos nacionais, assumem o confronto entre o Estado e as populações para representar o problema.

Todavia, a produção cultural foi amplamente responsável pela ampla inserção dessa ideia no imaginário da população brasileira. Da Bossa Nova ao Tropicalismo, passando pelos regionalismos eruditos, a música sintetizou os avanços estéticos e conceituais pelos quais passava nossa produção cultural e que elaboravam a ideia de

\footnotetext{
${ }^{21}$ Texto do release da peça, fornecido pela Brava Companhia.
} 
povo brasileiro. Também é na música que podemos apreender de maneira mais explícita o entrelaçamento entre cultura popular de esquerda e mercado como base da organização social que passou a ser vigente no período da ditadura.

Esse quadro, bem desenhado por Marcos Napolitano (2011) em sua livredocência e que nos ampara substancialmente, nos permite entrever a participação que a performatividade advinda do teatro teve no processo, compreendendo a música também a partir de sua dimensão espetacular, o que auxiliou na articulação da indústria fonográfica e derivou na ideia de Música Popular Brasileira. Os encontros culturais ganharam forma cênica principalmente nos primeiros anos da ditadura. $O$ teatro de resistência produzido nos primeiros anos pós-golpe foi contraditório ao tentar dar um arranjo formal ao movimento de aproximação com as classes baixas que havia sido interrompido pela ação do golpe. Em 1964, por exemplo, o show Opinião, que tinha entre seus representantes artistas ligados ao extinto CPC, colocou em cena a "descida do morro" (que já era tema de outras obras dramatúrgicas, como Pedro Mico, e Eles não usam black-tie, a partir de um tratamento ideológico novo, que remonta à Bossa Nova em sua sofisticação musical, embora sirva como exemplo da tentativa de retomar o contato direto entre artistas e classes populares, mediada pela associação entre performance teatral e música, como sugere Napolitano:

\footnotetext{
Da bossa Nova esse espetáculo herdou o tratamento diferenciado dos materiais sonoros populares, oriundos do "morro e do sertão", materializado, sobretudo, nos arranjos e nas performances de Nara Leão. Por outro lado, o público estudantil e jovem, formado a partir da Bossa Nova nacionalista, também estava lá. Opinião incorporou a forma do teatro de revista, tradicional espaço popular de crítica ligeira ao contexto social e politico (NAPOLITANO, 2011, p.74).
}

Os artistas ficavam responsáveis por levar para o palco as diferentes classes sociais unidas por meio do cancioneiro popular e "Em certo sentido, Opinião radicalizava e tentava realizar os termos do Manifesto do CPC" (NAPOLITANO, 2011, p.76), ainda que carregado de contradições imputadas ao termo "popular". No show Opinião, a música "resultava principalmente como resumo, autêntico, de uma experiência social" (NAPOLITANO, 2011, p. 76), na qual se agregavam conceitos que forjariam uma unidade nacional, já que "para efeito ideológico a música popular - que como o futebol, é manifestação chegada ao coração brasileiro" (SCHWARZ, 2008, p. 
80) - era associada à democracia e à autenticidade popular na resistência contra o regime dos militares.

Colocando-se como uma autocrítica ao campo musical e teatral de esquerda anterior ao golpe, o espetáculo procurou desenvolver formas populares de comunicação, negando tanto o "teatro de autor" quanto a "música de elite". O show Opinião mostrava também que o golpe não tinha acabado com o movimento de cultura épica e popular do $\mathrm{CPC}$, já que as formas de trabalho e de luta que neles tinham sido praticadas estavam vivas e resistiam, dentro do espetáculo, dentro do grupo que se formou a partir dele e sobretudo na recepção calorosa do público. Essa cumplicidade - entre palco e platéia compostos, em sua maioria, por estudantes - foi fundamental para produzir um acordo que "transformou o lugar social do palco" e lançou as bases para a música de protesto e para a estruturação da indústria fonográfica. Por outro lado, o show Opinião se destaca também por ter "assumido a necessidade de colocar os problemas socioculturais do país em uma perspectiva mais 'popular' que 'nacional'”, questão essa que se tornaria o centro dos embates estéticos durante o regime ditatorial, diferenciando-se das proposições que o precediam no pré-golpe.

Como descreve Schwarz (2008), sob influência do PCB, a associação entre ambas as ideias teve papel central para que se projetasse a necessária unidade social. A "hegemonia cultural de esquerda" que, em sentido oposto a um regime de direita, orientou a produção artística durante toda a ditadura, se deve, até certo ponto, às ambiguidades implicadas nessa associação conceitual. A pergunta "Qual a composição social e de interesses do movimento popular?" foi, para Schwarz (2008), mal respondida pelos artistas mais vinculados ao populismo, posto que "a composição das massas não é homegênea", como se pôde averiguar nos anos seguintes de maneira prática:

Não por acaso, a hegemonia nas lutas culturais de esquerda também mudou de foco: o nacional-popular, pedra de toque da ação cultural do Partido [PCB] desde os anos 1950, o realismo como linguagem fundamental da arte e o intelectual como formulador e mediador do idioma cultural comum da aliança de classes passaram por uma profunda crítica (NAPOLITANO, 2014).

Como resultado dessa crítica aos imperativos do $\mathrm{PCB}$, somada às novas problemáticas que emergiam de uma leitura atenta acerca das apropriações liberais da 
cultura de esquerda - pautada pelo uso da cultura nacional-popular como unificadora do ideário de nação sob os ditames do mercado -, a produção cultural nos anos 70 diversificou-se intensamente, apontando para novas relações entre cultura e corpo social. O central para nossa análise é que, historicamente, novos paradigmas passaram a ser perseguidos pelos "simpatizantes" das classes populares a partir de parâmetros como a democratização do acesso à produção, linguagem popular e aprofundamento da investigação acerca das especificidades formais das culturas locais, encontradas apenas no contato direto com as comunidades, em detrimento da uniformização dos pressupostos nacionais.

Nesse sentido, o movimento que se estabelecera a partir da ideia entusiasta de "encontros culturais" e de "ida ao povo", que tinha como objetivo dar forma a uma cultura nacional-popular de esquerda, mudou de forma, dando lugar a uma atividade cultural militante mais difusa, sem qualquer centralismo com relação a suas proposições. Essa militância, também prenhe de contradições, em parte mantinha a crítica ao sistema econômico, em parte aprofundava-se na representação de um popular idealizado, católico e sem luta de classes, que enfatizava certa "pureza" das formas populares e das práticas culturais comunitárias, incorrendo em problemas de representação.

Ainda que as perguntas centrais que se materializavam nessa corrente de ação cultural de verve militante se referissem a quem se destinavam as obras e qual o material a ser representado como popular, perguntas estas comuns também à corrente hegemônica ligada ao PCB, as respostas apartavam a categoria "povo" da categoria "nação" sem apreender a dialética intrínseca a esse enunciado dualista, como exposto por Napolitano (2011): As classes populares eram valorizadas a partir da sua cultura cotidiana, pragmática, local e comunitária, voltada para uma efetiva e silenciosa resistência diante da modernização socioeconômica do capitalismo, patrocinada pelo regime militar.

O que estamos apontando é que, se nos "encontros culturais" anteriores a 1970 a representação das classes populares (ainda que permeada pela mediação da "classe média" como forma de materialização dos discursos) mantinha a questão de classes no centro do debate, a partir dessa data a associação entre os setores da classe média intelectualizada e as classes "populares" passaria a buscar novos caminhos, que 
pressupunham os populares como autores de suas próprias narrativas, mas sem necessariamente se pautar por esse ideário. Como descreve Sader (1988), em Quando novos personagens entram em cena, o medo e a perseguição política aos militantes durante a década de 1970 fizeram com que os movimentos de resistência e luta do período amenizassem os discursos mais aguerridos à esquerda, em prol da sobrevivência e da continuidade da luta. Nesse sentido, a própria experiência social em uma sociedade classista fundamentava a continuidade de uma práxis pautada por tal ideário, embasada também na integração entre antigos militantes do PC e a população.

Dá-se, portanto, um importante deslocamento que, se levarmos em conta a continuidade da atuação cultural-militante do TUOV, nos interpela com uma pergunta bastante distinta a respeito das formas pelas quais os diversos encontros entre trabalhadores e classe artística se deram na nossa tradição cultural. Pode-se sugerir que dessas práticas basistas e militantes, privilegiando os novos personagens que ganhavam voz na política nacional, tenham surgido os pressupostos que fundamentam a valorização da autenticidade do lugar de fala - tão vigente no discurso neoliberal como parâmetro estético a ser incorporado pela crítica. Contudo, reconhecendo a importância da contraposição de pontos de vista para uma representação complexa da sociedade de classes, o trabalho do TUOV parte do pressuposto de que todos os envolvidos com a produção de suas peças são trabalhadores, ou seja, populares.

Nesse sentido, quando Corinthians, meu amor - segundo Brava Companhia (2011) propõe a paródia de um encontro cultural na periferia, o grupo está, em todos os sentidos, nos colocando diante da possibilidade de retomar questões historicamente mal resolvidas e apaziguadas pela pretensa união nacional forjada pela ditadura. Tal passo é dado ao nos interpelar com uma diferenciação entre a identidade de classes pautada pela figura do trabalhador e a identidade cultural popular, que passou a alimentar os debates da esquerda a partir da década de 1970. A estas duas perspectivas soma-se uma nova terceira ideia, proposta por Tiarajú Pablo d'Andrea, em A formação dos sujeitos periféricos: cultura e política na periferia de São Paulo (2013), tese na qual defende a formação de um "sujeito periférico." A hipótese defendida pelo autor aponta para um novo agente das transformações sociais, que por meio da atuação cultural nas periferias e a partir de novas formas de representação da população pobre - agora representado como periférica - demarca sua colocação dentro do espaço urbano e na luta de classes. 
Em face disso, a Brava Companhia tece uma importante contribuição acerca da problemática composição dos sujeitos da luta de classes contemporânea. Cada um dos enunciados pressupõe aspectos distintos de convergência para o conceito de "popular", que precisam ser avaliados para nos afastarmos de suas ambiguidades.

A sobreposição das ideias ilumina, contudo, uma importante pergunta que se fundamenta no fracasso da unidade nacional, posto que o processo de modernização do país não superou as desigualdades econômicas e sociais que estão na base do Estado brasileiro. A paródia dessa união, portanto, serve ao debate na medida em que torna evidente a ausência de convergência a partir de qualquer uma das idéias formuladas.

Antonio Candido, em Formação da literatura brasileira (1993), sublinha a contradição presente na consolidação da literatura nacional, que se constitui na ausência de um público letrado capaz de compor um sistema literário. Subjacente a isso, o crítico torna explícita a natureza complexa não só da produção literária nacional, como também da organização social a que se refere, sendo que a ideia de "nação brasileira" constituise a partir da produção de "documentos" sobre o país, mas sem a participação do "povo" em sua formulação.

É importante ressaltar, contudo, que a produção cultural e artística da classe trabalhadora não teve início apenas conforme esses "documentos" passaram a ser "iluminados" pela intelectualidade. A produção é anterior, e é tão somente a inscrição nos cânones que tardou a ser reconhecida. Foi, inicialmente, por meio da música que aqueles que eram objeto de consideração da obra estética se tornaram autores e passaram a interferir ativamente no cânone. Por sua vez, a paulatina formação desse sistema integrou aos poucos as vozes marginais de maneira profundamente inventiva. A Bossa Nova e o show Opinião são manifestações nas quais podemos apreciar essa interlocução, já que foi, sobretudo, por intermédio da música, da canção popular e do samba que se consolidou um discurso de formação nacional e uma forma artística capaz de ocupar o imaginário da população.

Mantendo-se esse pressuposto, a ação do rap e os seus reflexos no imaginário das classes baixas tornou-se objeto de análise sistemática por parte da academia, no sentido de se compreender quais as novas inflexões sociais que essa forma estética propõe no tocante à representação de classes. Nesse sentido, tanto Tiarajú D'Andrea 
quanto Walter Garcia, Celso Frederico e Acauam Oliveira ${ }^{22}$, entre tantos outros autores, vêm contribuindo ativamente para organizar a bibliografia, lançando luz para a formulação de novas hipóteses acerca dos recursos simbólicos aos quais a periferia recorre para se representar. Nesse sentido, o fenômeno da cultura periférica e a hipótese de que tal movimentação cultural implicaria a formulação de um novo sujeito histórico, conforme defendido por Tiarajú D'Andrea (2013), expande seus desdobramentos estéticos para um movimento mais amplo, composto por saraus, literatura, grafite, assim como o teatro:

Há realidade demais no rap do grupo. Para analisá-lo, antes de tudo é preciso esclarecer de qual lado do muro se vive. $\mathrm{O}$ endereço parece definir muitas opiniões sobre uma obra de arte que expressa não a, mas uma visão crítica do muro enxergado pelo lado da periferia (GARCIA, 2004).

Contudo, ainda que, como supõe Walter Garcia, a maior parte dos autores aposte na ideia de que as formulações da cultura periférica alcançam uma leitura de totalidade sobre o sistema, tal leitura assumiria como verdadeira a ideia de uma sociedade interligada por um muro que a separa em centro e periferia, tornando estrutural este dualismo. Ainda que a realidade a que se refere as letras de rap aponte para a enorme diversidade presente na periferia e se oponha à falsidade ideológica que produz uma equidade de direitos entre moradores das regiões centrais e moradores da periferia, a ideia que vincula periferia à exclusão econômica, no entanto, não expressa a mobilidade das relações desiguais presentes no neoliberalismo. Não se considera que uma parcela significativa da população vive de maneira precária e longe de quaisquer direitos sociais também no centro das cidades, além de não se atentar para a inclusão social de uma parcela dos moradores da periferia que conseguiram uma pequena ascensão social por meio das políticas sociais dos últimos governos do Partido dos Trabalhadores.

Com isso, ainda que a ideia de sujeito periférico e a sua produção conservem, em seu âmago, a representação da desagregação do mundo do trabalho e do Estado de Direito em suas formas artísticas - o que é um avanço representacional considerável -, é também possível reconhecer em sua formulação as divergências e contradições

\footnotetext{
${ }^{22}$ Cf. debate em: Garcia (2004, 2011, 2013); Oliveira (2015); e Frederico (2013).
} 
inerentes ao fato de essa ideia se distanciar da estrutura produtiva e da realidade material vinculada ao mundo do trabalho.

Aparentemente atenta a esse contexto, a Brava Companhia nos convida para um encontro cultural com "sinal trocado", tanto no que se refere à geografia da cidade, quanto à relação entre os interlocutores. Nesse encontro, os "elementos populares" da Brava Companhia se apropriam da narrativa de César Vieira e parodiam a ideia de “união popular" proclamada seja pelos representantes da esquerda da década de 1970, seja pelos "sujeitos periféricos", transformando-as à luz de uma atitude crítica. Essa inversão realça uma importante contradição inerente a essa camada da sociedade, que ganha o nome de "classe média" (que pode ser também a "nova classe média" do lulismo) e que, contraditoriamente, opera um gestus representativo das elites, ainda que, materialmente, vivencie impasses análogos aos do proletariado.

Essa inversão de sentido retoma também a própria perspectiva da luta de classes, que, de certo modo, foi apagada pelo processo histórico arregimentado pela ditadura e pela abertura política neoliberal. Somente por meio da análise crítica dos interesses populares se tornaria possível encontrar os verdadeiros temas do teatro político, posto que a composição das massas não é homogênea. Isso exige deslocar os termos do debate para fora do universalismo burguês e assumir que o proletariado compõe praticamente todos os setores da vida nas cidades, ainda que na forma de trabalhadores precarizados e desorganizados. Sendo assim, o percurso que separa um espectador do lado de lá ou do lado de cá do muro é tomado como movimento proposto pela obra, que inviabiliza sabermos, exatamente, de que lado estamos, já que é uma vivência objetiva, mas não necessariamente geográfica, que determina essa fratura.

Na peça, como também é no caso do rap, a crítica ao Estado surge mais uma vez como ponto central, trazendo a indústria cultural, a polícia e a igreja como instituições que organizam a gestão das populações pobres e a violência. Contudo, assumindo a premissa de que o discurso de unidade nacional e de "união popular" são farsas ideológicas que produzem o apagamento das contradições, a Brava Companhia parodia essa construção de imagens do popular, sendo, por vezes, mais verdadeira do que o próprio objeto parodiado. Esse procedimento revela tanto a inexistência de unidade quanto a ausência de protagonismo real dos chamados "sujeitos periféricos", permitindo 
que os discursos hegemônicos saltem visivelmente na boca de todos os seus personagens, ainda que eles sejam oprimidos pela mesma estrutura desigual.

Os outros sambas entoados ao longo da peça são, em sua maioria, de autoria do grupo e todos trazem, em alguma medida, não apenas o discurso da união popular para o centro do debate, como também a descrição da vida periférica. A ideia de nação calcada no samba e amplamente explorada pela indústria fonográfica carrega consigo seu contraponto histórico e seu lugar de origem, que remetem à imagem do morro e da favela, fazendo com que ambas as perspectivas sejam amplamente questionadas pelo espetáculo como fruto de seus lugares no mercado.

A associação entre Estado e mercado, que perpassa todo o espetáculo como objeto de crítica, se revela intrínseca ao processo histórico, flagrando a apropriação feita pela indústria cultural dos elementos mais "combativos" da cultura popular e seu decorrente esvaziamento. Nesse sentido, também o rap e outros aspectos da cultura, como o próprio carnaval e o futebol, são incorporados como recursos formais e parodiados, evidenciando uma investigação acerca das formas de resistência inerentes a essas práticas e seu uso como pastiche no mercado cultural.

Ao constituir uma espécie de "repente" dialógico dentro da canção "Inferno colorido", o espetáculo nos mostra o quadro que a mídia criou sobre a realidade periférica a partir dessa mesma associação entre Estado e mercado, propondo novas explorações dessa forma musical. A resposta à pergunta colocada pela canção, que envolve os espectadores na construção da reflexão, aciona a dimensão coral do público como fundamental para a solução da pergunta.

A imagem colorida criada pela mídia também é problematizada por meio do recurso paródico. A favela não é nem bela, nem rica ou alegre como pinta o quadro midiático quando se propõe a representar a figura popular, sequer suas relações comunitárias são fonte de uma alegria popular genuína, mas sim forma de sobrevivência às mazelas sociais e ao descaso do Estado e do mercado. Contraditoriamente, no seio dessa realidade subjugada, uma sociabilidade coletiva sobrevive e uma produção cultural combativa é produzida e, se tomadas em perspectiva crítica, podem desembocar na coletivização da luta. Aqui, portanto, o uso do recurso dialógico do repente como representação dessa forma coletiva busca, como já sublinhamos, uma relação "didática" com o público que, ao ser convidado a participar como coro nas canções, é também 
estimulado no sentido de tomar parte sobre quais são os "agentes sociais" responsáveis por esse "inferno colorido" retratado, propondo um processo formativo.

O procedimento é de cunho popular, o que, conforme descreve Fredric Jameson (1999), no livro $O$ método Brecht, constitui a base para algumas das formas do teatro épico. Em Corinthians, meu amor - segundo Brava Companhia, seu uso interpela o espectador como poderia se esperar de um coro presente em uma peça didática, explicitando que parte das descobertas sobre o todo da obra "serão colocadas e resolvidas pelas formas que o povo encontrar, e não pelas que nós imaginamos serem as fórmulas salvadoras", como afirma César Vieira (2007) ao descrever o trabalho do TUOV. Sua recorrência nas formulações de tradição oral certificam a apreensão e o diálogo com o público para a continuidade de uma construção coletiva. Essa dimensão estética passa despercebida se tomada a partir de uma noção hierarquizante da forma, que não toma as estruturas relacionais da cultura como proposições estéticas e modelares. Para nossa análise, essa dimensão tem primeira importância, posto que não se resume a um jogo formal, mas propõe formalmente um procedimento de apropriação crítica que impele o público a formular respostas.

Esse debate alcança novas dimensões quando contraposto às formas de representação do popular que vislumbram se incorporar ao aparato institucional da burguesia sem romper efetivamente as alianças com o mercado. Nesse sentido, a estrutura do Estado burguês segue em plena atividade, dissolvendo suas perspectivas combativas amenizadas pelo pacto liberal. Isso se dá também pela própria ideia de setores articulados em torno de seus lugares de fala ou identidades, quando estes setores se permitem compactuar com uma segmentação do mercado cultural, sem fazer frente ao problema do sistema produtivo. Em sentido oposto, a presença do samba fora do contexto de conciliação de classes a ele conferido pela indústria fonográfica está representando em Corinthians, meu amor - segundo Brava Companhia algo que só um ponto de vista periférico é capaz de capturar sobre aquele encontro: na periferia da periferia do capitalismo, os guetos e os quilombos não deixaram de existir, sendo que os encontros culturais podem ser como quilombos, que refletem um processo social ainda vivo, subscrito na formação do Estado brasileiro. 


\section{O Gestus do trabalhador sem identidade de classes - trabalhador sem classe e classe sem trabalho}

As relações entre Corinthians, meu amor - segundo Brava Companhia - Uma homenagem ao Teatro Popular União e Olho Vivo e o texto original são pautadas pela alteração da função dos personagens dentro da obra. Como já destacamos, o texto original foi escrito, inicialmente, para ser um roteiro de cinema que, embora nunca tenha sido filmado, alavancou a versão teatral publicada. Conforme explica César Vieira,

Corinthians, meu amor é um texto em aberto e sempre colocado como uma motivação para um espetáculo popular. Foi sempre modificado, transformado e ampliado [...] Seu título e tema dão margem a que elementos populares criem colocando sobre o conflito original suas ideias e objetivos (VIEIRA, 200, p. 87).

O roteiro cinematográfico escrito por César Vieira serviu como guia para a encenação da Brava Companhia, que foi feita bem aos moldes do que desejava o autor. Os elementos populares. do grupo elaboraram uma nova dramaturgia, na qual desenvolveram os temas apresentados sem perder de vista o período histórico que os separa do texto original e a busca por uma estética popular. A propósito, por exemplo, da primeira temporada de Corinthians, meu amor encenada pelo grupo Teatro Casarão, no final da década de 1960, o jornal Possível, de São Paulo, publicou uma pequena crítica ao espetáculo, que aponta algumas questões:

\footnotetext{
Inexiste um conceito de teatro popular. Ele deve ser dinâmico e nunca estático. Um espetáculo pode ser feito com base num texto popular e resultar não popular. O teatro popular não tem regras fixas, não tem receita. O ideal seria fazer um texto simples, sem pretensões, mas com intenções, montado por operários e apresentado em bairros da periferia. Em síntese, teatro popular é a soma do texto, grupo, montagem e local popular. Todavia, nesse campo qualquer tentativa é importante (VIEIRA, 2007, p. 86-87).
}

Não podemos ignorar que parte central da dificuldade em refletir sobre o teatro popular advém da diversidade de ideias que o conceito de "popular" abarca, alem de suas condições efetivas de produção e reprodução. A maneira como a Brava Companhia se insere artisticamente junto à comunidade sugere esse fio de continuidade em relação às propostas lançadas por seus antecessores ligados à militância, em particular o Teatro 
Popular União e Olho Vivo. Ao observarmos características como a organização interna do coletivo, temas, procedimentos de criação, vínculos com movimentos sociais e pesquisa de linguagem específica para o contexto, podemos concluir que o grupo se atem ao estudo e à elaboração de alguns parâmetros para um "teatro popular". Esse é o teatro que, realizado na periferia, pretende contribuir com a crítica à atual organização de classes, e que serve de contraimagem ao mercado, pautando-se por uma popularização da arte que não ocorra via indústria de massas, e que busque na trajetória de engajamento entre arte e política novas questões e maneiras de tratá-las no campo formal. Mais uma vez, a montagem de Corinthians, meu amor - segundo Brava Companhia nos oferece elementos para essa reflexão.

O texto original, de César Vieira, é escrito do ponto de vista de uma câmera filmadora chamada "Gabriela", uma câmera de fabricação nacional que se descobre corintiana e que, ao receber a incumbência de realizar um documentário sobre a cidade de "São Paulo - a cidade que mais cresce no mundo" (VIEIRA, 2008, p. 42) para o programa de TV onde trabalha, percebe por todos os lados a presença do time, ofuscando as outras relações sociais presentes na cidade.

Para Augusto Boal, o Corinthians de César Vieira "não é apenas um time de futebol, mas uma encarnação do povo: é metáfora”(BOAL, In: VIEIRA, 2007, p. 3336). Tendo isso em vista, a câmera Gabriela, que nutre o mesmo amor que o autor, vai a campo e registra alguns eventos públicos importantes da vida da cidade: o carnaval, a corrida de São Silvestre, um comício, os festejos de finados e, por fim, a final de um jogo do Corinthians.

$\mathrm{Na}$ introdução, a narradora desculpa-se pela "ausência de análise psicológica e de verniz literário; afinal, uma câmera é uma câmera”(VIEIRA, 2008, p. 41) e afirma que se aterá apenas a gravar os fatos da vida (reforçando a imparcialidade de seu ofício), mas ressalta que às vezes ela se apaixona. Assim, o autor dá início a uma narrativa fragmentada em que diversos personagens "populares" são representados vivenciando situações comuns à sociabilidade urbana. Sem nexos causais que conectem uma e outra cena e mantendo-se o pressuposto de que a carga do popular implica em diferenças de classes sociais e suas distintas ocupações no mundo do trabalho, o eixo de convívio entre os diferentes personagens passa a ser a cidade, representada como um espaço político que traria unidade ao todo. Atento a uma nova configuração urbana e às 
suas particularidades, o texto situa os trabalhadores em espaços e eventos públicos (o que nos permite apreender também uma segmentação do trabalho à margem das organizações sindicais ou do campesinato), que passam a ser observados pelas lentes da câmera Gabriela, avidamente interessada pela vida popular:

\footnotetext{
e assim, mudei o roteiro, filmei o que eu quis, o que eu vi e tudo é verdade porque eu vi com meus olhos alvi-negros.

E olhem, quando eu falo em Claudio, Luizinho, Balthazar, quero dizer Neco, Brandão, Dino, Servilho, no passado e Flavio, Rivelino no presente e outros que virão no futuro...

Os personagens também: o operário Atílio, a pipoqueira Elisa, o guarda civil, o playboy, o seminarista Thomaz, o camelo, não são apenas eles; é você, é a torcida do plá plá plá, é a cidade inteira, os que vieram e os que virão (VIEIRA, 2008, p. 44)
}

A clivagem de classes no texto de César Vieira pode ser observada a partir da relação dos personagens entre si. Ainda que a figura do patrão permaneça operante embora apenas como referencialidade no discurso dos trabalhadores -, o que mais se sobressai nas cenas são as outras instituições da vida pública, como a igreja, a política, a polícia, os esportes e a cultura. À medida que todos os personagens vivenciam situações mediadas por tais institucionalidades, a peça constrói um todo que a narradora Gabriela chama de "Corinthians". Compreender metaforicamente essa ideia, como proposto por Augusto Boal no texto "Arte e dignidade no TUOV”, que faz prefácio ao livro de Cesar Vieira (2007), é também assumir uma equivalência entre esses personagens que tem como baliza uma noção abstrata de "popular". Todavia, é de primeira importância salientar que tanto Boal quanto Vieira não sustentam suas práticas artísticas em tal noção abstrata, mas em uma aguerrida atuação militante vinculada às condições reais de produção das populações.

A opção metafórica, por conseqüência, pode ser analisada e compreendida se levarmos em consideração uma atitude recorrente do teatro de resistência no período. Uma parcela significativa da produção artística, principalmente entre 1964 e 1968, optava pela aliança de classes como forma de se opor ao regime ditatorial, acreditando que dessa união viria a se formar uma frente de resistência, como de fato aconteceu. A produção dramatúrgica e crítica, por sua vez, começava a buscar formas para não apenas estimular essa união e essa resistência, como também para representar a 
sociedade civil pressionada pelo Estado, tornando visíveis os impasses a partir dos quais emergiam os conflitos de classe.

Antecipando uma característica que passou a ser ainda mais recorrente na produção artística a partir dos anos de 1970, o roteiro de César Vieira tende a representar a diversidade da "sociedade civil" sem dar maiores atenções às relações entre a população e o Estado ditatorial. A forma como isso aparece é sutilmente representada dentro de situações cotidianas. Com isso, persiste no texto de 1966, ainda que de maneira subjacente, a expectativa de uma aliança de classes, ainda sob influência da ideologia nacional-popular, além de um idealismo com relação à formação da indústria cultural no país, aspectos que correspondem à tônica do período e que se tornam o centro do debate crítico, sobretudo na década seguinte.

A ideia de "nação corintiana", por sua vez, já opera um deslocamento no conceito de nacional-popular que aponta para a presença crescente da indústria cultural de massas no fortalecimento da ideia de nação, sublinhando sua prerrogativa espetacular, conforme descreve Marcos Napolitano (2011). A partir de 1966 a aliança entre os liberais, ligados aos setores da comunicação, e o PCB começou a se evidenciar, tendo sido definitivamente estabelecida quando, com o fim da luta armada, o risco de a burguesia se associar a práticas radicais de guerrilha parecia extinto. Segundo Napolitano (2011), esse período marca também a crescente presença dos cantores de esquerda na indústria fonográfica e televisiva, posto que a expectativa cultural ainda tramitava em torno da necessidade de uma unidade simbólica de nação. É interessante salientar que, para uma significativa parcela dos artistas engajados na resistência à ditadura, o papel da televisão e a popularização da cultura que poderia advir dela carregavam um certo otimismo, embora já fossem objetos de muitas críticas.

Podemos acompanhar esse debate em textos de Oduvaldo Vianna Filho, como "Moço em estado de Sitio", de 1965, no qual o autor busca encontrar um acabamento dramatúrgico para esta questão amplamente debatida em seus escritos teóricos, sobretudo aqueles organizados por Fernando Peixoto (VIANNA FILHO, 1983). Vianinha, por exemplo, ainda que tenha passado a integrar o quadro da rede Globo de televisão, produziu uma dramaturgia autocrítica que buscava refletir sobre essa questão, colocando perguntas que ganharam consequências críticas na produção da década de 1970. Napolitano (2011) nos demonstra também que a década seguinte foi marcada, 
sobretudo, por uma produção cultural que optou por se colocar à margem da indústria do entretenimento, assumindo, em alguns casos, a forma de vanguarda; em outros, a forma de militância, como presente também na tese de Alexandre Mate (2008), na qual acompanhamos alguns desdobramentos do teatro militante produzido na década de 1970 que se estendem à década seguinte.

No que se refere ao tratamento dado ao nacional-popular em Corinthians, meu amor, de César Vieira, o ponto de vista narrativo, da câmera Gabriela, ainda que guarde um otimismo problemático na relação com a indústria cultural, já apresenta indícios de um deslocamento, ressaltado por Mota (1978) em Ideologia da Cultura Brasileira (1933-1974) ao abordar o trabalho de Antonio Candido na década de 1970. Tal deslocamento, que se daria em definitivo somente em 1973, também sugere não mais a consciência nacional, mas a consciência de classes e, posteriormente, a consciência cidadã como balizas para se pensar a produção cultural. Mesmo que a câmera se arrogue “100\% brasileira, nacionalíssima” (VIEIRA, 2008, p. 42), já que todas as suas peças foram trocadas por outras, feitas aqui e por trabalhadores do Brasil, não é isso o que move a seleção dos quadros por ela narrados. Antes disso, é sua paixão pelo Corinthians que a leva a registrar os fatos da vida popular à sua maneira, incitando uma "revolução das câmeras" (VIEIRA, 2008), ou seja, dos trabalhadores da indústria cultural, que corroboraria uma outra forma de narrar a história. A câmera Gabriela é fruto de trabalho nacional e se apresenta ao leitor como trabalhadora: "Fui refeita todinha por trabalhadores do Brasil. Até o óleo que lubrifica minhas rodinhas é fabricado na Penha [...] A firma em que trabalho (trabalho em termos porque só recebo em espécie [...]" (VIEIRA,2008, p. 42).

Tendo isso em vista, a óptica da câmera nesse contexto histórico não se constitui como adesão irrestrita à crescente indústria cultural, mas, principalmente, como uma sugestão formal que incita a uma experiência épica e crítica, em consonância com a análise feita por Walter Benjamin em "A obra de arte na era de sua reprodutibilidade técnica" (2012) sobre os avanços dos meios de produção. Atento a isso, na montagem de Corinthians, meu amor - segundo Brava Companhia o grupo se apropria do recurso formal épico, mas aprofunda-se, particularmente, no engajamento com os temas por ele suscitados. A indústria cultural deixa de ser um espaço a ser disputado internamente e passa a ser abordada de diferentes ângulos. 
A personagem Gabriela, que antes era o ponto de vista predominante, se converte em mais um dos personagens, uma jornalista que, apaixonada pela cultura popular, decide realizar o seu mestrado tendo como objeto a periferia da cidade e sua população. A personagem, que visivelmente não está inscrita naquele contexto periférico, reflete um olhar externo que se relaciona de maneira fetichizada e idealizada com a ideia de povo e com seus produtos culturais. Por meio dessa atitude a peça evidencia comicamente o Gestus de uma classe média elitizada que não se inscreve criticamente no contexto da luta de classes, mas que se apropria do popular a partir da criticável lógica folclorista e romântica. A personagem, destoando completamente, veste verde em meio à nação corintiana, diferenciando-se do "povo" ainda que se afirme fiel torcedora do Timão.

Com isso, o debate entre os novos grupos militantes da década de 1970 e o PCB ganham corpo e gesto na representação de Gabriela. Isso nos possibilita avaliar criticamente a possibilidade de que esse impasse possa, de fato, ter permeado algumas das produções do período, dissolvendo, portanto, uma falsa oposição entre PCB e novas formas de esquerda.

\footnotetext{
A ideia da superação entre direita e esquerda surgiu com o fim da URSS e do então chamado campo socialista, quando se passou a pregar o fim das ideologias, o fim do Estado, o fim dos partidos, o fim da politica e até o fim da História. Era o necrológio com que a direita pretendia sepultar definitivamente a esquerda.

Mas o que veio depois foi na direção oposta. O fim da História trouxe mais guerras e profunda recessões econômicas. A resistência à hegemonia norteamericana no mundo produziu cada vez mais resistência. Surgiram governos antineoliberais, de esquerda. Países começaram a construir, pelos Brics, uma alternativa ao mundo construído à imagem e semelhança dos EUA.

Não somente a História não acabou, como aprofundou suas contradições, que reafirmou sem papel de motor da História. Divididos pelo neoliberalismo e pelas guerras, direita e esquerda voltaram a alinhar-se de forma cada vez mais aberta. Se forças como a social democracia se alinhou com a direita, surgiu uma nova esquerda, antineoliberal e pacifista (SADER, 2017).
}

O que nos chama a atenção aqui é o fato de que Corinthians, meu amor segundo Brava Companhia cria uma personagem para abarcar um debate crítico que tem como princípio o gesto da classe média de ida à periferia, mas que apenas se torna problemático quando assume formas idealistas e fetichizantes, possíveis de serem 
flagradas não na totalidade da ação, mas nas nuances que um Gestus, sempre relacional e socialmente consolidado, estabelece com essa escolha política.

Não podemos deixar de apontar, dessa forma, que a dimensão idealista da personagem Gabriela norteia - como contraponto - a aproximação desta pesquisa com o material levantado por Corinthians, meu amor - segundo Brava Companhia. O Gestus central que ela representa e a partir do qual se relaciona com o todo é o "deslumbre", que a torna incapaz de perceber qualquer contradição na narrativa, ou de exercer qualquer autocrítica com relação à pertinência de seu trabalho junto às classes populares. Para ela o "povo" é objeto do qual se apropria no sentido de compreender a dimensão espiritual da vida simples, registrada em uma pesquisa jornalística ou acadêmica. A oposição entre sujeito e objeto implicada no Gestus da personagem ignora a possibilidade dos populares serem sujeitos de sua própria história, que precisa ser apropriada por ela para que assuma os contornos esperados pela elite, produzindo a manutenção de um lugar de diferenciação.

A oposição entre Gabriela e Olho Vivo é ressaltada pela peça para evidenciar duas atitudes distintas de aproximação das classes médias com relação às camadas populares. No caso de Olho Vivo, a noção de que a classe média faz parte do mundo do trabalho urbano adentra a realidade material, assumindo um ponto de vista de classe que não corresponde aos parâmetros estéticos da indústria cultural. Os impasses da vida objetiva dos envolvidos compõem sua dimensão cultural, ainda que em sua precariedade, em oposição às formas adotadas por Gabriela, nas quais apenas aquilo que é aceito como idealmente popular pode ser incorporado, produzindo o fetiche com relação a suas formas.

Com isso, Gabriela protege a peça ao demarcar um ponto negativo na aproximação com o espetáculo, baseado, por sua vez, na crítica histórica a essa atitude apologética e idealizada que pregaria uma "pureza do popular" vinculada à autenticidade de quaisquer de suas práticas. A personagem, ainda que pareça pertencer a outra classe, é uma trabalhadora, assim como os outros integrantes do coro, e se diferencia dos demais sobretudo por estar visivelmente implicada em destacar-se individualmente, obtendo o sucesso profissional.

A crescente fragmentação do mundo do trabalho em suas facetas neoliberais, que concernem o setor de serviços, o empreendedorismo individual, o refluxo da 
organização sindical e o aumento do desemprego no setor industrial, gerou, historicamente, o enfraquecimento de alguns parâmetros relativos à luta de classes tal e qual defendida pela esquerda clássica. Marcos Napolitano (2011) identifica que a apropriação da cultura de esquerda feita por parte dos liberais presumia o apagamento de termos relativos à problemática de classes na produção estética, permitindo que vigorasse com maior ênfase a resistência ao regime pautada pela identidade cultural. Tal resistência, problematizada já em seu tempo tanto pelos setores mais engajados com a militância, tinha como base o projeto tropicalista de alegoria do subdesenvolvimento por meio de um uso moderno das especificidades culturais.

Nesse caminho, o autor sublinha que a militância que se formaria ao longo da década de 1970 , ainda que sustentasse a defesa ao povo e aos seus direitos como bandeira, o fazia com base na defesa da "pessoa humana", sem com isso realçar os vínculos antagônicos entre as diferentes classes sociais. A crise instaurada pelo golpe militar afetara, sobretudo, três instituições centrais e as respostas que viriam a surgir tinham como base uma revisão de seus pressupostos; a igreja católica, as organizações marxistas e os sindicatos foram obrigados, assim, durante a década de 1970, a buscar novas formas de atuação devido a um "descolamento com seus públicos respectivos", fazendo com que essas agências buscassem "novas vias para reatar suas relações" (SADER, 1988, p.144). O caminho, que os novos militantes buscavam recuperar à luz das experiências militantes anteriores ao golpe, deu-se pela aproximação com a vida cotidiana pela via do trabalho de base nas periferias, no sentido de articularem-se novas formas que atingissem seus objetivos.

\footnotetext{
Mas, no mundo das maquinas de cinema sou famosa, citada. Fui eu quem iniciou a "revolução das câmeras." Isso mesmo. Sou assim como um Marx, no meu meio. Só que fui mais longe, porque Marx ficou na teoria e eu entrei de sola na prática. Questão de determinismo histórico ( VIEIRA, 2008, p. 41).
}

É de primeira importância recordar que se tratava não de uma novidade, mas de uma retomada com relação a práticas que haviam sido interrompidas pelo golpe. Todavia, para os envolvidos, havia algo de novo emergindo sobretudo das demandas, que se diferenciavam sobremaneira das bandeiras do início da década de 1960. A articulação entre essas frentes foi fundamental para movimentar a política nacional, 
apresentando um novo horizonte de lutas implicado, sobretudo, na melhoria concreta das condições de vida dos trabalhadores. Por meio de práticas sociais fundamentadas nas especificidades culturais da população, demandas como o custo de vida e o acesso à saúde emergiram como conteúdo no debate público que se contrapunha à alegoria resignada do subdesenvolvimento.

\begin{abstract}
Nas representações que daí emergiram iria ressaltar um certo tipo de humanismo. Nelas se valorizavam as práticas concretas dos indivíduos e dos grupos em contraposição às estruturas impessoais, aos objetivos abstratos e às teorias preestabelecidas. Valorizavam-se também os atos de solidariedade através dos quais os indivíduos transcendiam a rotina vazia imperante na sociedade. E valorizava-se fundamentalmente uma sede de justiça que denunciava a situação social vigente. Em todos esses aspectos, as novas práticas discursivas atingiam a racionalidade tecnocrática e o individualismo burguês dos discursos dominantes (SADER, 1988, p. 194).
\end{abstract}

Com isso, o processo organizativo que se sustentara no sentido de uma "consciência de classes" foi historicamente substituído pela noção de "consciência cidadã", o que desobrigava a apreensão da totalidade do campo político, supondo uma responsabilidade social arregimentada na micropolítica e na experiência material da população. A representação, portanto, dos atores sociais, passaria a se dar segundo esse novo ideário que, apartado da luta de classes ou de alegorias totalizantes, buscaria na luta pelos direitos sociais a realização de uma sociedade igualitária, em decorrência da supressão e da perda de referenciais de luta..

Essa nova esquerda era nova sobretudo pela diversidade de seus conteúdos e por não aceitar uma matriz discursiva única que trouxesse um horizonte comum a todas as práticas. Ainda que a articulação mediada pelas comunidades eclesiais de base precise ser mais bem analisada e consolidasse uma espécie de conexão, a característica central dessa organização era a dimensão fragmentária de tais lutas, dado ao fato de que as pautas eram tomadas diretamente da experiência social dos participantes dos movimentos e portanto não se unifiavam sob uma bandeira comum. As divergências com relação à sua integração dentro do escopo institucional já eram latentes em muitos casos; todavia, quando o novo sindicalismo - que já se consolidara a partir de um tensionamento com o aparato burocrático - lançou as bases para uma disputa dentro das esferas de poder, o movimento convergiu e se associou ao projeto democrático da fundação do Partido dos Trabalhadores. 
Tendo isso em vista, a recente contribuição de Tiarajú D’Andrea (2013) é determinante para o avanço crítico do debate e para compreendermos o lugar da cultura dentro desse quadro. Quando entram em cena, a partir da década de 1990, a pobreza, o tráfico e a violência da ainda corrente miserabilidade da população marginalizada, um novo salto nas questões de classe se torna necessário. Tendo por base o movimento musical do rap e uma diversificada produção cultural que emergia também no contexto periférico, uma outra representação das classes populares ganhava forma, contribuindo para o orgulho e a autoestima dessa população e engendrando, como propõe o autor, o conceito de "sujeito periférico" (D'ANDREA, 2013). Todavia, o que está à margem de suas proposições e parece nortear a nossa interpretação acerca do trabalho da Brava Companhia é o fato de que essa produção foi especialmente estimulada por políticas culturais cuja base são os pressupostos democratizantes preconizados e defendidos pela esquerda basista da década de 1970 e que foram transformados em projetos de governo posteriormente.

Esse parece ser justamente o problema central no Corinthians da Brava Companhia. Os limites políticos de tais práticas militantes tornam-se explícitos diante de uma institucionalização que as subjugou; os incentivos à produção artística tornam-se uma ferramenta de gestão populacional mediada por editais e por um mercado cultural incipiente. A realidade da sobrevivência dos grupos culturais e dos artistas periféricos, e o seu engajamento, não se avêm mais com aquela militância política, mas com a expectativa de inclusão nesse precário sistema que é exposto pela peça ao deflagrar as dificuldades de uma ação efetiva de embate contra o capital por meio da cultura.

Para apreender o problema da "consciência de classes" dentro desse novo contexto - no qual também as lutas de esquerda tomaram para si o acesso aos direitos sociais como bandeira, e a desigualdade econômica cravada na geografia da cidade como realidade a ser combatida -, é necessário avaliar, da mesma forma, as transformações materiais, sobretudo no que se refere ao mundo do trabalho.

A tônica do debate conflagrado por essa esquerda com origem na década de 1970 já era, além das demandas constituídas pelo novo sindicalismo, a questão do desemprego, do subemprego e dos trabalhadores precarizados, que encontrariam formas distintas de lutar por suas demandas nesse contexto insurgente. Como descreve Sader: 
Os movimentos constituídos a partir de trabalhadores precários, donas de casa, de favelados, tendo por base a esfera da reprodução, teriam de se apoiar em outras referências. Tinham consciência da falta de poder de barganha e pressão na esfera da produção. Desenvolvendo suas reivindicações na esfera da reprodução, não dispunham de um poder no nível econômico para sustentar seus movimentos. Tampouco podiam apoiar-se no plano legal. [...] Seus movimentos apoiaram-se em estruturas comunitárias, fundadas na solidariedade grupal. Excluídos de empregos estáveis, de direitos consagrados, eles constituíram suas próprias referências (SADER, 1988).

Nesse sentido, a ação militante dos artistas teatrais tinha proporções singelas no que se refere à articulação da cena política, embora fosse também a pressão dessas novas formas organizativas e reprodutivas que consolidava as balizas de suas práticas estéticas. É indispensável, portanto, para que possamos compreender a proporção que tomaram as práticas culturais contemporâneas, assumir as perspectivas formais e processuais concebidas pela Nova Esquerda como paradigmas de uma efetiva atuação popular. O avanço alcançado pelo movimento "Arte Contra a Barbárie" transformaria em política de Estado a manutenção de um projeto cultural com base nessas prerrogativas, como descreve Paulo Arantes:

\begin{abstract}
Nos tempos que correm não é pouca coisa converter consciência artística em protagonismo político. Foi uma vitória conceitual também, pois além de expor o caráter obsceno das leis de incentivo, deslocaram o foco do produto para o processo, obrigando a lei a reconhecer que o trabalho teatral não se reduz a uma linha de montagem de eventos e espetáculos. Nele se encontram, indissociados, invenção na sala de ensaio, pesquisa de campo e intervenção na imaginação pública (ARANTES, 2007b).
\end{abstract}

A formulação cultural do problema apenas ganharia contornos problemáticos quando, em face do projeto neoliberal, o Estado assumiu para si o ônus de fomentar a produção. Para as camadas populares, o estímulo viria em forma de políticas de incentivo ao pequeno e microempreendedor, evidenciando-se a fratura dessa "sociedade de direitos". Fundamentalmente, o direito defendido foi o direito ao trabalho, embora outros direitos sociais, como os próprios direitos trabalhistas, tenham sido reduzidos. Nesse sentido, o sujeito cunhado por Tiarajú, ainda que evidencie a importância pública das políticas culturais, demonstra também que, em parte, sua função é, sobretudo, a inclusão de parcela da população no sistema produtivo a partir de pressupostos pautados pelo sucesso individual do sujeito burguês, e não mais fundamentada na solidariedade 
grupal. A dimensão combativa e coletiva dessa produção e suas possibilidades políticas ficam a cargo de uma atitude crítica presente em sujeitos forjados pela luta, e nunca a despeito dela.

À luz desse novo contexto, a Brava Companhia trabalha atentamente a construção dos Gestus de cada um dos personagens - evidencia-se aqui uma leitura atenta de um ponto de vista para a construção de tais gestus - , tentando, ao mesmo tempo em que toma seu lugar periférico como base para uma identificação com o popular, distanciar os Gestus dos personagens representados, analisando-os criticamente à luz da totalidade. Não é a narrativa de qualquer uma dessas figuras que orienta os enunciados, mas a pergunta sobre de que formas as relações entre os diferentes Gestus impedem que se reconheçam como oprimidas por um mesmo sistema e assumam, efetivamente, seus lugares como sujeitos históricos implicados com o problema coletivo. Para tanto, as diferentes tentativas de se salvar individualmente são contrapostas pela peça a uma estrutura formal que representa algumas dimensões desse sistema, assim como são contrastadas pela imagem dessa solidariedade. Acompanhando a tese de Tiarajú, as organizações mais atuantes nas regiões periféricas, como a igreja, o tráfico, a policia e, sobretudo, a produção cultural proporcionam situações em que os Gestus de cada um dos personagens podem ser verificados, revelando suas contradições processuais.

Tão somente a partir dessa realidade comum, mimetizada na cena por meio da configuração espacial de um boteco, torna-se possível imaginar uma experiência social de similitude dentro da sociabilidade da cidade, sobretudo da periferia, dada a ausência de uma esfera pública representativa. As reações de todos os tipos representados se diferenciam substancialmente, alocando o problema totalmente no presente da representação dramática. Essa característica, que produz um novo impasse a ser superado, desnuda o problema de um dualismo entre centro e periferia ao mesmo tempo em que reivindica uma atitude dialética diante dessa oposição. O Gestus sempre é social embora neste caso o representado não seja particular ou de classe, mas se faça presente em diversas clivagens sociais ligadas ao trabalho cultural, posto que o sistema que implica sua produção e reprodução é o mesmo e independe da geografia da cidade.

Nossa atenção analítica, portanto, está em flagrar qual a ação desse sistema sobre o conjunto e como esse conjunto reage, assumindo a interpretação de cada um dos 
Gestus e posicionamentos representados a partir de suas relações com o contexto abarcado pela obra. Em sentido oposto à tese defendida por Tiarajú, consideramos que a peça da Brava Companhia revela não a formação de um novo sujeito, mas a crise dos sujeitos políticos descritos por Sader, posto que apenas

\begin{abstract}
Constitui-se um novo sujeito político quando emerge uma matriz discursiva capaz de reordenar os enunciados, nomear aspirações difusas ou articulá-las de outro modo, logrando que indivíduos se reconheçam nesses novos significados. É assim que, formados no campo comum do imaginário de uma sociedade, emergem matrizes discursivas que expressam as divisões e os antagonismos dessa sociedade (SADER, 1988, p. 60).
\end{abstract}

No entanto, como cada elemento popular representado pela peça assume características muito divergentes, aceitando como único ponto de convergência o enunciado do time popular mediado pela indústria cultural, a matriz discursiva que ordena os significados não sustenta uma prática comum de confronto. Os antagonistas de cada um dos tipos representados seriam distintos entre si e, se não se colocariam em confronto com o centro, tampouco assumiriam uma atitude necessariamente crítica ao sistema. Também a presença de um público que tem origem em todas as regiões da cidade e que é incorporado pela estrutura formal da peça como personagem presume a possibilidade de um confronto de matrizes discursivas, ainda que esse público compartilhe dos mesmos pressupostos críticos. É, portanto, na divergência entre tais enunciados e aspirações que se produz efetivamente o espaço para uma ação política e coletiva, sobretudo porque são realçados os mecanismos de separação e dessolidarização presentes entre os tipos sociais representados e visíveis em diversas clivagens sociais do mundo do trabalho.

O objetivo é autocrítico, portanto, e vislumbra uma ação contra o sistema que produz aquelas práticas sociais, não contra os personagens representados. A análise do Gestus de cada um desses tipos pretende inviabilizar qualquer acepção moral sobre as figuras. A peça apenas nos permite observar as formas por meio das quais esses tipos se relacionam com a constituição desse espaço público, embora, de relance, nos dê indícios sobre quem são, efetivamente, esses personagens dentro da sociabilidade periférica. A sutileza com que o Gestus a ser criticado se sobrepõe a imagens difusas na composição dos tipos representados confere organicidade à crítica sem criar um confronto moral com o problema. Mais do que isso, se estivermos atentos às relações que estabelecem 
entre si, poderemos identificar criticamente quais os Gestus reproduzidos por nós, espectadores, sem nos prendermos a eles como se estivéssemos diante de um espelho, ou seja, sem nos identificarmos irrestritamente.

Para tanto, além de Gabriela, sobre a qual já tecemos alguns comentários, teremos em cena na peça da Brava Companhia um palhaço, chamado Carne Moída, um aspirante a cantor popular, chamado Marcito, um pretenso intelectual, chamado Eronides, um seminarista bêbado, o Cotonete, Elisinha, Atílio, e um público composto por trabalhadores, que podem ser também populares fiéis torcedores do Corinthians.

A construção desses personagens se dá a partir de "duplos" que dialogam diretamente com a comédia popular. Cada um desses duplos apresenta dois lados de uma relação social específica, que, assim como o Gordo e o Magro, ou os palhaços Branco e Augusto, são opostos complementares e indissociáveis pertencentes ao universo complexo das paródias populares. Com isso, a paródia proposta pela Brava Companhia lança luz sobre relações sociais modelares presentes na sociabilidade do trabalho cultural. Quando lidas do ponto de vista de uma Companhia situada na periferia da cidade, tais relações parecem apresentar apontamentos críticos a partir dos quais passamos a compreender as dificuldades de mobilização política por parte dos populares, uma vez que a realidade material, conforme representada pela peça, os manteria enclausurados dentro daquele bar. A tentativa de um realismo burguês é substituída por uma espécie de realismo grotesco, pautado pela mesma atitude investigativa do primeiro, mas no qual o "excesso de real" é deformado a ponto de fazer uso da incompletude dos sujeitos como parte da proposição. Por exigir a atividade do espectador, no sentido de preencher o universo dos personagens representados com suas próprias experiências, o procedimento implica em aprendizagem acerca do processo, embora não formule um discurso definitivo.

Nesse sentido, o realismo não é propriamente um realismo interpretativo, mas sobretudo uma atitude diante do real no tratamento do material cientificamente apreendido da observação do corpo social, como nos traz indícios Brecht no seu "Pequeno organon para o teatro" (BRECHT, 2005). O realismo grotesco desenvolvido, como procuramos observar, recorre sobretudo às formas populares de interlocução, consolidando uma forma que se distingue do realismo burguês por não se basear nas relações intersubjetivas, mas em relações gestuais que dão forma às relações sociais. 
É importante salientar que a construção dramatúrgica e a composição do espetáculo não procuram representar "A Periferia". A representação da totalidade das relações sociais existentes nessa sociabilidade seria uma outra tarefa, que demandaria, inclusive, a compreensão do sentido dessa operação dualista que se subscreve no debate contemporâneo, sobretudo nos meios culturais.

O que a peça pretende, e realiza, é a representação alegórica da crise de um processo histórico de mobilização popular e de militância, travado a partir da década de 1970 e que contava com a participação de diversos setores da sociedade, inclusive os setores culturais e artísticos. Esse processo, que aparece na peça de modo a sugerir uma nova ruptura naquilo que fora idealizado por seus articuladores, parece estar em vias de desaparecer, sendo mais uma vez suprimido.

Por sua vez, não é apenas por meio da alegorização que o espetáculo trabalha, pois inclui também aspectos processuais que são representados, opondo a dimensão estática presente na alegorização à representação do processo, propondo uma dinâmica que dá um relevo dialético ao espetáculo. Com isso a peça busca - por meio da análise crítica dos Gestus encontrados contemporaneamente naqueles que foram, outrora, os novos personagens da cena política nacional - retomar algumas questões e proposições que estavam na base desse projeto moribundo, tentando dar um último fôlego à luta de classes e à militância cultural.

\subsection{A cultura}

O primeiro duplo a ser analisado é, efetivamente, composto por dois palhaços: Carne Moída e Marcito, ambos representantes da produção cultural, sendo o primeiro um miserável malandro e o segundo, um aristocrático bobalhão. Carne Moída é a representação de uma cultura totalmente precarizada e marginalizada que é posta em cena, de maneira carismática, na figura de um palhaço, embora sem camisa, sem sapato e sem nariz. Quando Gabriela, abobalhada e infantilizada, fala de sua admiração por palhaços, aproximando-se com a câmera filmadora ostensivamente, o personagem recorre ao grotesco para visibilizar a violência do gesto da personagem: "Então chega 
aí, fia... grande ser humano... Olha o cheiro do mano!” (BRAVA COMPANHIA, 2015, p. 208).

Carne Moída, longe de ser um palhaço europeu, está quase nu, é alcoólatra, bandido, sujo e, a certa altura, sabemos que é procurado pela polícia como um perigoso bandido. Todavia, recorrendo à malandragem para, ao mesmo tempo, conquistar o público e sobreviver naquele "inferno colorido", o personagem sabe roubar as coisas certas e fazer as melhores piadas contra o poder. O problema coletivo posto pela peça no início da trama - a ausência de um televisor para assistirem ao jogo da final do campeonato do Corinthians - é resolvido pelo malandro, que rouba um aparelho de televisão e o leva para o boteco, fazendo a felicidade de todos. De maneira subliminar, o Palhaço, associado à marginalidade, reflete o problema da ação do tráfico no centro da sociabilidade periférica, relacionando suas acões e procedimentos a uma vertente da produção cultural vinculada ao rap, que revela uma desordem constitutiva e inerente à ordem social neoliberal.

Tendo isso em vista, o Gestus representado é o esforço em não se integrar à ordem, posto que esta já opera como uma ação violenta e agressiva em direção aos que ocupam suas margens. Toda e qualquer empreitada institucional é vista com desconfiança por parte do personagem; no entanto, a maneira com que se relaciona com o poder é ingênua e insuficiente para derrubá-lo. Como exemplo, podemos descrever a primeira intervenção da polícia no boteco, quando o personagem se esconde e, fingindo estar no rádio, engana o policial que o procurava naquele recinto.

$\mathrm{O}$ único momento em que o personagem adquire uma virulência vem mediado por um rap, por meio do qual revela a violência presente em si. A identificação com a indignação do personagem é imediatamente silenciada pela polícia e apropriada e capitalizada pelo poder da indústria cultural. Contraditoriamente, a miséria torna-se matéria-prima de uma poética indignada e esse mesmo esforço por se diferenciar da ordem e se opor a ela passa a ser fetichizado pela ação da indústria cultural. Posto que o conteúdo virulento e combativo precisa ser silenciado para que o produto continue a existir, a miséria precisa permanecer, restando da indignação apenas a forma.

Em oposição ao Palhaço Carne Moída, Marcito, seu duplo constitutivo, tem "pinta de playboy e vida de office-boy" (BRAVA COMPANHIA, 2015, p. 206). Mostrando as chaves de sua moto, do seu carro e do seu apartamento na Av. Paulista, o 
personagem flerta com algumas mulheres do público, pautando-se por seu lugar de protagonismo cultural emergente para conseguir algumas moças. Representante da cultura periférica que tem como objetivo ser incorporada pela indústria do entretenimento, Marcito se destaca em seu protagonismo, fazendo a ressalva de ser o único galã em meio ao populacho. Se valendo disso para um possível apagamento de sua identidade de classes, ele se esforça profundamente para corresponder às normas da ordem, incorporando a competitividade do mundo do trabalho contemporâneo e buscando se adequar às normas e regras da elite. Como cantor de música popular, o personagem consegue ainda algum dinheiro e importância dentro do sistema vigente, utilizando-se de todas as suas armas para fazer valer a lei do mercado e do consumo, o que faz com que aparente pertencer a outro lugar de classe.

$\mathrm{O}$ número musical que apresenta no final no intervalo entre o primeiro e o segundo tempo é uma forma de divulgar seu trabalho autoral, que “"agloba' vários âmbitos do leque artístico" (BRAVA COMPANHIA, 2015, p. 230) e conta com a participação de uns parceiros da Brava Companhia, que "tão precisando divulgar a imagem deles" (BRAVA COMPANHIA, 2015, p. 230), já que trabalham com teatro. A música é um pagode rastaquera que tende ao brega e, ainda que a letra traga os problemas sociais à tona, isso se dá na canção de Marcito de modo a transformar a indignação em problema, buscando o apagamento da experiência de injustiça social embora se valha dessa realidade como campo simbólico. A exposição dessa inversão, contudo, é feita de modo a denunciar o problema de representação presente na música.

Ao analisarmos esse duplo composto por Marcito e Carne Moída, podemos inferir algumas nuances do problema representado, que se refletem como impasses para a produção cultural periférica e estão na base da pergunta proposta por Tiarajú D’Andrea (2013). O autor, ao longo de seu estudo, busca apontar a potência da produção cultural periférica, na medida em que questiona o leitor sobre as possibilidades políticas e emancipatórias de tal produção. $\mathrm{O}$ questionamento se deve à percepção de que essa produção também já configura um nicho no mercado cultural, com marcas, lojas e um padrão comportamental pautado pela ideia de um público alvo "periférico".

Em vista dessa crítica, a contradição que pauta essa representação da cultura periférica por parte da Brava Companhia expõe a marginalidade e a integração ao 
sistema como duas faces de uma mesma moeda, sendo que uma reivindica a outra para se fazer valer. O problema, como apresentado por Marcito, se estende a vários âmbitos do leque artístico e engloba toda a produção cultural, esteja ela no centro ou na periferia, já que a autenticidade da experiência da precariedade e da marginalidade passou a ser um valor para integrar um sistema de concorrência por editais que se alimenta dessa própria miserabilidade e precariedade.

A força da ação desses duplos se dá, principalmente, pelo fato de seus tipos sociais não serem particularizados ou diretamente relacionados a quaisquer personalidades da vida cultural periférica. No caso de Corinthians, meu amor-segundo Brava Companhia, a identificação excessiva com qualquer uma das figuras representadas, ou a transposição direta entre um tipo social e uma pessoa reconhecível, inviabilizaria o conteúdo autocrítico da peça. O sistema cultural fechado que se formou nas periferias da cidade tem por base essa contradição e, nesse sentido, a piada autorreferenciada feita por Marcito, indicando que seus companheiros da Brava Companhia precisam promover suas imagens, traz indícios dessa realidade para dentro da cena. A competitividade entre os grupos culturais suscitada por essa política de editais e financiamentos para a cultura provocaria um verdadeiro Corinthians $\mathrm{X}$ Palmeiras caso os tipos representados fizessem menção a qualquer uma das personalidades implicadas nesse sistema.

\subsection{Os ideólogos}

Os personagens representados por Marcito e Carne Moída associam-se diretamente aos novos atores sociais que passaram a figuram nos movimentos de lutas populares a partir da década de 1970. Conforme descrito por Sader (1988), a essa nova configuração do mundo do trabalho e das classes populares na periferia da cidade de São Paulo somavam-se a igreja e a intelectualidade. Eronides e Cotonete, representantes dessas duas forças, formam um outro duplo que tem como base o contexto da militância dos anos de 1970. Registrando o contratempo dessas presenças na atualidade, os personagens são, por um lado, marcados pela melancolia e ausência de respostas para um processo que tomou rumos diversos daqueles idealizados no período; por outro, 
representam o poder implicado na ação dessas instituições, - a igreja e a academia - o que pressupõe a manutenção de suas práticas em meio à sociabilidade periférica, como também novas formas de relação e novos conteúdos que se vinculam a esses tipos sociais.

Aqui, a problemática representada gira em torno da autoridade com que certas figuras pretendem determinar quem e o que é o "popular" ou a "periferia". O papel contraditório imbricado nessa disputa de narrativas diversas acerca do popular foi cumprido, em parte, por essas duas instituições, sobretudo fazendo frente às narrativas constituídas pela indústria cultural. Nesse sentido, o Gestus de ambos se diferencia do autoritarismo da representação midiática, encontrando como base uma atitude que visa implicar-se na vida material da população, não apenas no campo simbólico.

Na sexta cena, “Aconteceu Enquanto Eu Dormia Ou Enquanto Eu Torcia Era Torcido", o processo é evidenciado em um intermezzo historicizante que remete ao protagonismo da intelectualidade e da igreja nas organizações populares da década de 1970. A interferência de Eronides, um professor acadêmico que toma a frente com o intuito de contar a história do time do Corinthians ao público, é carregada por um tom farsesco, trazendo à cena um discurso regado por palavras irreconhecíveis, que transformam em complexo algo muito simples de se expressar. Afirmando que vai explicar a peça Corinthians, meu amor ao público, para, em seguida, dizer que vai, na realidade, contar a história do time, ele não faz nem uma coisa, nem outra; a cena, assim, caminha no sentido de apresentar uma pequena história da luta de esquerda ao conjugar as palavras não a partir de seus significados literais, mas a partir da relação entre as expectativas geradas pelos signos.

A primeira coisa que chama a atenção na construção desse tipo social é que, desde o início da peça, o personagem está pronto para seu grande momento, o que faz com que, já na apresentação dos personagens, Olho Vivo o repreenda, pois ainda não chegou a hora de suas colocações aparecerem. Muito embora o personagem tenha por base um papel histórico desempenhado pela intelectualidade oriunda da universidade, a primeira versão da dramaturgia, publicada no Caderno de Erros II (BRAVA COMPANHIA, 2011) ${ }^{23}$, dá margem ao reconhecimento de seu Gestus também aplicado

\footnotetext{
${ }^{23}$ Para esta pesquisa nos baseamos em três versões distintas do texto da Brava Companhia. A primeira é um documento cedido pelo grupo que data de 2011; a segunda versão, também de 2011, foi publicada no
} 
sobre uma prática intelectual organicamente constituída a partir de práticas sociais e culturais periféricas. Novamente essa interface produzida pela análise gestual problematiza uma noção moralizante que induziria a separação entre intelectualidade e prática material das camadas populares. Nesse sentido, o centro do debate proposto pelo personagem é, especialmente, a importância do conhecimento, ainda que seu uso seja franqueado e explorado como autoridade por indivíduos e instituições, servindo de moeda de troca no campo das diversas narrativas.

Construída a partir do tipo popular do Dottore (inspirado na commedia dell'arte), sua forma interpretativa já sugere que o público deva questionar e duvidar das intenções daquela figura. Ali, Eronides representa o intelectual farsante e pomposo que, por costume, é ridicularizado nas formas populares. A dramaturgia corrobora essa desconfiança, já que as formas mais estranhas ao vocabulário popular são também as palavras e construções de uso comum no vocabulário acadêmico. Por sua vez, são exatamente essas palavras que o grupo se esforça para estranhar, expondo o erro do professor e nos fazendo perceber sua "charlatanice" ao mesmo tempo em que se sublinha suas reais intenções.

\begin{abstract}
Eronides - Muito bem, muito bem, Sr. Olho Vivo. Pode deixar que daqui eu assumo. Farei agora uma intervenção de teatro hérpico, para que todos possam compreender o que ninguém ainda entendeu. Caso houver alguma dúvida, por favor, não me interrompam. Bem, primeiramente, estamos aqui assistindo a uma peça de teatro da Brava Companhia. Segundamente, essa peça se chama-se Corinthians, meu amor. Porém, tanto sem duvidamente, eu irei ressoltar alguns aspectos importantes da trajetória desse clube, dentro desse processo liminar, que é a história (BRAVA COMPANHIA, 2015, p. 223).
\end{abstract}

A figura do personagem alimenta todos os preconceitos historicamente construídos por parte da população com relação à intelectualidade. $\mathrm{O}$ discurso é posto à prova, seja do ponto de vista dos literatos, dada a inadequação à norma culta e os incontáveis erros, seja do ponto de vista popular, dada a prepotência retórica e o autoritarismo com o qual se afirma detentor da verdade sobre o real sentido da peça. Em ambos os casos ele erra, e é precisamente em seus erros que o personagem diz a que vem. Embora justifique a sua participação com base no intuito de explicar a peça ao

Caderno de Erros II da Companhia; e uma terceira, que estamos assumindo como a versão final, publicada em 2015 no Caderno de Erros IV: peças erradas que tentam emperrar a máquina, livro no qual a Companhia organiza e publica toda a sua dramaturgia. 
público, afirmando que o tema de sua "palestra" seria a trajetória do time Corinthians, o que, efetivamente, o personagem realiza é a sobreposição de dois discursos. A operação torna ambos igualmente verdadeiros e falsos, operando na chave da contraimagem que flagra a contradição inerente ao personagem.

A intervenção de teatro "hérpico" proposta pelo grupo distancia a narrativa e explicita o lugar ocupado pela Brava Companhia dentro daquele contexto periférico de onde se origina a prática do grupo. Ao desempenhar no Parque Santo Antonio um papel contraditório, comprometido tanto com pressupostos referenciados na intelectualidade quanto na tradição de esquerda (e corriqueiramente associados à academia), mas também apresentando uma certa desconfiança em relação às assertivas que advêm da mesma instituição, dada sua constituição classista, a práxis do grupo na relação com a população do bairro tenciona a vinculação com o conhecimento, seja ele popular, seja ele acadêmico. O lugar que a companhia se dispõe a ocupar pressupõe o erro como parte da construção coletiva com o público.

Nesse sentido, as afinidades com os pressupostos de uma intelectualidade orgânica, atuante junto ao âmbito popular durante a década de 1970 e que buscava contribuir para a organização e o trabalho de base estão no horizonte não apenas do grupo, mas também do personagem representado. A expectativa de atuar intelectualmente junto às lutas populares e periféricas não foge ao quadro e constitui o problema do Gestus representado por Eronides. A ansiedade com que o personagem quer dar um norte vanguardista para as lutas - associada a um lugar de poder que ele projeta sobre si - instaura a contradição de sua atuação, e, nesse caso, apreende uma dimensão autocrítica do processo, que busca superar essa contradição ao expor suas implicações.

$\mathrm{Na}$ sequência, o personagem apresenta o seu assistente, Cotonete, um seminarista que será o auxiliar do professor em sua exposição. A opção ressalta a figuração de um mundo letrado, posto que o padre aparece como um dos principais representantes do letramento para os setores que se encontram à margem do capital. $\mathrm{O}$ cânone literário nacional não cansa de representar essa ocupação, uma vez que, antes de ser uma função religiosa, foi por muito tempo um meio de acesso às letras. De fato, historicamente, a integração ao clero foi um dos poucos meios de inscrição social para a população pobre. No caso de Cotonete, essa realidade parece tornar-se ainda mais 
contundente, posto que o seminarista afirma de maneira direta que "eu sou um seminarista e nem acredito em Deus” (BRAVA COMPANHIA, 2015, p. 223), expondo sua ausência de religiosidade. Contudo, ao longo da peça, acompanhamos a melancolia desiludida e alcoólica em que mergulha o personagem inúmeras vezes, o que nos leva a entrever outras nuances históricas sobre seu papel no contexto das lutas sociais periféricas.

Os duplos antitéticos, como afirma Candido (2010), estabelecem valores que figuram oposições diretas, "entre as quais é preciso escolher"; o autor afirma, ainda, que "uma das grandes funções da literatura satírica, do realismo desmistificador e da análise psicológica é o fato de mostrarem, cada um a seu modo, que os devidos pares são reversíveis"(CANDIDO, 2010, p. 41). Arriscaríamo-nos a afirmar que são também complementares, sendo que a dialética possível entre eles demonstra que um e outro são resultados de processos sociais equivalentes. A contundência do duplo intelectualidadee-igreja parte de uma mesma premissa ideológica, que confere historicidade ao quadro ao tornar premente a função de instituições ideológicas subscritas nas práticas materiais da população.

O processo histórico nos dá a ver que a atuação conjugada dessas duas institucionalidades configurou os laços que unem populações à margem dos processos políticos centralistas. A atuação política na região ao longo dos anos de 1970, por exemplo, passa por essa ação conjunta entre esquerda católica e uma intelectualidade de esquerda fragmentada pela ação repressiva. Engajada com os sindicatos e com a formação de base pautada pelas ideias de educação popular preconizadas por Paulo Freire, e com um corpo teórico consistente, essa intelectualidade buscava reinscrever-se junto aos populares, procurando caminhos para superar uma crise oriunda da derrota que a desarticulara.

Nesse sentido, premissas do PCB e da intelectualidade de esquerda (que movimentavam a vida política do período anterior ao golpe) se associaram às práticas das comunidades eclesiais de base, fundamentais para a articulação da trazendo novos contornos às práticas militantes, e tornando-se, portanto, determinante para os deslocamentos ocorridos nas formas de confronto ao sistema econômico estabelecidas no período. É extremamente importante observar que, devido à grande presença das igrejas nas periferias, a figura do padre sugere para essa população tanto o discurso mais 
moralista e conservador quanto o mais progressista e politizado, possibilitado pela presença da teologia da libertação em parte das comunidades eclesiais de base, sobretudo no período da ditadura.

As mesmas implicações e contradições permeiam ambas as institucionalidades, e consistem na articulação e composição de enunciados que antecedem a experiência material ou o contato com a população. Essas tradições inscrevem-se na realidade periférica por vezes de maneira orgânica, mas em alguns casos produzem impasses profundos, que nem sempre são bem vistos pela população. Nesse sentido, a participação da intelectualidade junto aos processos sociais nas regiões periféricas tende a ser alvo de maior desconfiança, posto que, ainda que atue sistematicamente para alcançar avanços sociais, esta também está associada à perversão dos valores locais ou ao subsequente abandono por parte das instituições que antes respaldavam tal participação. A presença da igreja, todavia, permanece até os dias de hoje e pode-se observar na Zona Sul de São Paulo a enorme importância de alguns padres e organizações católicas nas movimentações políticas da região. Essa participação pode ser observada sobretudo na participação do Padre Jaime, ligado à pastoral desde a década de 1970, como documentado no Caderno de Erros III da Brava Companhia (2014) em um artigo de Eduardo Campos Lima que busca historicizar a movimentação política na região:

Foi no fim da daquela década ( 1960) que essa região estourou como área de mão de obra barata para as fábricas da avenida Nações Unidas. Nos anos de 1980, com a robotização, computadorização e otimização das fábricas, a mão de obra barata virou sucata e foi jogada para lá. Daí resultou uma grande onda de desemprego" lembra o padre Jaime Crowe, desde 1970 ligado às mobilizações do bairro.

$\mathrm{Na}$ primeira metade da década de 1970, foram realizadas as primeiras assembléias populares na região, tratando de temas como transporte, coleta de lixo e regularização fundiária. "Em 1974, começou o movimento contra a carestia, que nasceu das comunidades eclesiais de base, numa época de alta inflação. (...)

As expressões artísticas sempre andaram lado a lado com as mobilizações. "no próprio movimento da carestia, as encenações sempre foram muito importantes. Praticamente toda assembléia se iniciava com uma dramatização. Isso sempre esteve presente na história de luta do bairro," afirma o padre Jaime (BRAVA COMPANHIA, 2014, p. 79).

O depoimento registrado por Campos Lima data de 2013, e ainda em 2015 a atuação do padre junto aos movimentos da região se faz notar. Sua participação em 
mobilizações organizadas por grupos organizados da região, como foi o caso da ação realizada no cemitério do Jardim São Luis, em maio de 2015, presenciada pela pesquisadora, é fundamental para estabelecer um laço histórico entre as diferentes lutas.

\begin{abstract}
O tema da audiência foi "Juventude e resistência". O objetivo foi discutir e reivindicar do Poder Público, ações contra o processo de extermínio da população pobre. [...]

A audiência foi organizada pela Comissão da Verdade e da Democracia "Mães de Maio" e pelo Comitê Sociedade Civil Juventude e Resistência. Estiveram presentes diversas organizações sociais, o prefeito Fernando Haddad, o secretário de Direitos Humanos (SP), Eduardo Suplicy e seu secretário-adjunto, Rogério Sottili ${ }^{24}$.
\end{abstract}

Nessa data, alem de representantes ligados ao Estado, estiveram presentes na audiência pública representantes da igreja, entre eles o próprio padre Jaime, integrantes de torcidas organizadas de futebol, integrantes de saraus da região, professores da rede pública, trabalhadores de diversas áreas e moradores da região, alem de artistas militantes da Brava Companhia.

Nesse sentido, para fortalecer a complexidade do problema, a cena opõe ao duplo "detentor do conhecimento" a dimensão cultural incorporada pelos personagens Marcito e Carne Moída para, a partir das relações que estabelecem entre si, revelar o processo de apropriação do mundo letrado por parte dos populares. A "aula" tem início estabelecendo um diálogo entre a dupla de artistas periféricos, produtores de cultura, e os já referidos detentores da tradição literária e do conhecimento, que evidenciam o processo histórico que os antecede. Quando o primeiro quadro é apresentado por Eronides, mostrando o ano de 1910, Marcito é o primeiro a se destacar e a responder à pergunta, buscando mostrar serviço. O personagem parece querer acertar as colocações, mostrando que pode lidar com o instrumento do conhecimento e do mundo letrado com certo apreço e eficácia. Sua origem pobre é flagrada no Gestus de ascensão de classe, que corresponde ao da cena inicial, em que ele ostenta um poder (e bens) que de certo não tem. Por sua vez, o personagem o faz com tanta insistência e de modo tão demarcado e explícito que acaba revelando o seu contrário.

$\mathrm{Na}$ cena que estamos analisando, Marcito entra em contato com uma figura que é imediatamente associada à elite, o que coloca o galã periférico em uma situação de

\footnotetext{
${ }^{24}$ Disponível em: http://ontonrtv.blogspot.de/2015/06/maes-de-maio-audiencia-publica.html. Acesso em: 01 jul. 2017.
} 
outra ordem, revelando a perspectiva ideológica de suas ações quando associadas ao conhecimento. Diante do "mundo letrado", de posse da elite, o personagem é desmontado e se esforça por corresponder, de maneira equivocada, aos modos discursivos da classe almejada. Por sua vez, como Eronides não foi construído pela Brava Companhia como um representante stricto senso da elite intelectual, mas sim como representante de uma outra intelectualidade, ligada ao ideário de esquerda, sua função dentro da obra é, antes, criticar a dimensão classista do conhecimento acadêmico e seus correlatos "catequizantes". O curioso da cena é que os personagens que representam o campo do letramento são, como já afirmamos, escorregadios e pouco confiáveis, o que acaba por pregar peças no projeto de ascensão social do rapaz.

Eronides - Muito bem, vamos lá! Por obséquito, alguém aqui pode me dizer o que vê aqui? (Aponta para a placa onde se lê "1910").

Marcito - 1910!

Eronides - Onde você vê um número, eu vejo história. (Cartaz da Revolta da Chibata) Este foi o ano em que algo de extrema revelância para o povo aconteceu: a fundação do Corinthians. Muito bem. Vamos para frente. (Cotonete anda). Na história, meu querido estúpido, para frente na história. Alguém pode me dizer o que está vendo aqui? (Cartaz “1914”).

Marcito - Eu! Eu vejo história.

Eronides - Onde você vê história, eu vejo um número. 1914! Depois de uma batalha aterradora, o Corinthians, pela primeira vez, se sangrou campeão. (Cartaz da primeira guerra mundial).

Cotonete - Sagrou, Doutor. Sagrou (BRAVA COMPANHIA, 2015, p. 224).

A aula que se desenrola acaba por reforçar didaticamente o discurso da peça e, dados os sequenciais erros realizados pelos personagens, entramos em contato com uma breve história da luta de classes, que se configura como fim almejado pela companhia.

A Revolta da Chibata, que data de 1910, é o primeiro cartaz que aparece. Sua história remonta a um dos primeiros processos organizativos de cunho trabalhista na República Nacional e um dos mais importantes, pois exprimia os reflexos da escravidão no país que, apesar da abolição, seguia chicoteando os negros livres. Por essa razão, também o Teatro Popular União e Olho Vivo se ateve a esse fato quando estreou, em 2001, João Cândido do Brasil como forma de colocar em cena o episódio. Essa história, no Corinthians da Brava, é substituída pela fundação do "time do povo", colocando para o público a pergunta sobre qual fato histórico teria maior relevância. Uma vez que somos levados a duvidar do que o professor nos diz, a pergunta tem origem na percepção do erro, e não do enunciado. 
Na sequência, uma nova placa marca o ano de 1914, quando o time, em uma batalha, se "sangrou" campeão. Seguida por uma imagem da primeira guerra mundial, novamente apreendemos, pelo auxílio da contraimagem, não a sagração do time, mas o sangue derramado na guerra. O terceiro cartaz remete à Revolução Russa. Eronides aqui indaga insistentemente da plateia sobre o que aconteceu em 1917, para, por fim, concluir que nada de importante ocorreu para o "Corinthians", ainda que um dos mais importantes marcos da história da esquerda esteja figurado. A sequência estabelece, em paralelo, uma trajetória que sobrepõe o Corinthians à luta popular e, mesmo que a história contada se paute pelas vitórias do time do povo (que fazem com que ele se torne sagrado para os torcedores), as derrotas da luta e o sangue derramado ganham maior evidência, já que em nenhum momento a força das imagens representadas nos cartazes remete ao time. O que salta à vista, por sua vez, ao ser reforçado pelas imagens, é a luta como um nó associativo multiplamente explorado pela dramaturgia como um todo.

Eronides - Nossa! Como pude me esquecer! Me desculpem pelo colapso de memória. Esse é o momento mais importante de toda a palestra! É a hora da citação! Alguém pode me dizer o que está indescrito aqui?

Alguém - Eu! "Fui forjado na luta".

Eronides - Quem disse isso?

Palhaço - Ele ali! (BRAVA COMPANHIA, 2015, p. 224-25)

Carne Moída, em oposição a Marcito, representa a total marginalidade; ele é a sobra, os restos e os dejetos do mundo do trabalho. Ao entrar em contato com qualquer instância do Estado e do poder ao longo da peça, o personagem se esconde, no esforço de não interagir com as forças repressoras da elite. Mesmo quando ele é apontado como possivelmente "certo" em sua interação com o professor - na cena, quando um dos personagens lê o cartaz, ele é apontado pelo grupo como se fosse responsável pela resposta correta -, o Palhaço desdenha do acerto e da integração no jogo do conhecimento. O que observamos é uma atitude de desinteresse em pactuar com as regras colocadas, ainda que sua atenção esteja voltada a apreendê-las. Sua presença ali parece ser fundamental para questionar o lugar de poder presente no tom professoral, ao mesmo tempo em que revela uma atitude distinta diante do poder do conhecimento; uma posição que é negativa e que, portanto, produz outras possibilidades.

O professor, então, pede ao seminarista que lhe dê assistência; e na cena acompanhamos um salto na história da luta. A partir daí vemos passar, sem quaisquer 
comentários, cartazes que citam a crise de 29, nazismo, ditadura militar, até alcançar o ano de 1978 em um cartaz que mostra as greves do ABC: "Agora sim! Mobilização popular!!! Milênio de 70...” (BRAVA COMPANHIA, 2016, p. 225). Os anos de 1970 valem por um milênio, dada a quantidade de movimentações populares ocorridas à época. Para o professor Eronides, o que de principal aconteceu foi a invasão corintiana do estádio do Maracanã, em contraste com a imagem dos milhares de grevistas que ocuparam as ruas no mesmo ano. É de extrema importância demarcar aqui a presença e a participação do time do Corinthians no arcabouço simbólico da resistência à ditadura. No documentário Democracia em Preto e Branco (2014) podemos acompanhar o processo que levou o time a reestruturar suas direções no sentido de associar-se às ideias democráticas como marca simbólica de indignação contra o regime. No documentário de 2014, vemos Lula dando um depoimento em que atesta que sua maior expectativa como líder sindical era ver uma multidão de trabalhadores mobilizada tal qual vira nessa invasão do Maracanã. O documentário registra o trunfo de suas expectativas na greve geral de 1979.

Registrar esse momento histórico tem, para a narrativa, importância de primeira ordem, já que nos anos de 1970 foi engendrada a ideia de "sociedade civil" por meio da ação dos mais diversos atores sociais. Marcos Napolitano (2011) evidencia que no período já era reconhecível a dificuldade que a cultura, como ação política, tinha de acompanhar as transformações em curso na sociedade brasileira. Contudo, entendemos que a associação entre movimento sindical, movimentos sociais comunitários, intelectualidade, igreja, teatro, cultura popular, futebol e povo demarcava uma nova dimensão cultural, que marcou a história do país no sentido de ampliar-se a ideia de protagonismo popular na luta pela expansão dos direitos civis. Por sua vez, os dois cartazes seguintes mostram que a partir dos anos 2000, ainda que o "time do povo" tenha se tornado campeão mundial, foram feitas algumas alianças indevidas (na foto dos cartazes, vemos Lula e Dilma abraçando Sarney) que levaram o time a cair para a segunda divisão. A cena se fecha com a fala comemorativa do professor: "Mas não fiquemos tristes. Hoje o povo está deixando suas casas para se erguer a casa do Corinthians! É o minha casa, minha vida do Timão: o Itaquerão! ${ }^{25}$ ". Em seguida, aponta

\footnotetext{
${ }^{25}$ Itaquerão foi o apelido dado ao estádio do time do Corinthians, a Arena Corinthians, construído entre 2011 e 2014, no bairro de Itaquera, Zona Leste da cidade de São Paulo. O estádio foi também palco da
} 
imagens de despejos associadas ao logotipo do programa federal "Minha Casa Minha Vida"26.

Ao demonstrar que a luta de classes foi suprimida por outras formas de identidade popular, a cena torna explícito o conteúdo subliminar que estamos buscando comprovar. Nesse caso, a identificação com o Corinthians é a vertente histórica que faz com que possamos compreender por que é esse, e não qualquer time de futebol, o representante dessa cooptação, já que, em outras cenas do espetáculo, seria indiferente ser o "Chapetuba Futebol Clube" ou o "Barbosinha Futebó Crubi" o representante alegórico dessa paixão nacional. A compreensão de que o futebol não é apenas o esporte que congrega os corações brasileiros, mas que se inscreve objetivamente na realidade material do país é essencial para apreendermos seu papel simbólico. A apropriação e a ação mitificante da indústria cultural sobre quaisquer narrativas e práticas populares consiste em uma ação de contenção que sustenta muitos retrocessos na vida política. $O$ intelectual Eronides, propenso ao erro, revela o problema sem precisar recorrer ao poder de sua autoridade reificada, mas expondo o processo de conciliação de classes como contraponto à espetacularização do trabalhador e das lutas da Nova Esquerda. Expõe-se, portanto, por meio da contradição interna aos personagens, as lutas populares sendo reificadas pela mitificação da figura do Presidente Lula e do PT.

Associado tanto à construção do estádio do Corinthians (e às comemorações do centenário do time popular), quanto aos despejos e à violência empregada contra a população para conter as manifestações que começavam a tomar forma, a narrativa pessoal de herói nordestino e operário sindicalista, bem como a narrativa de resistência contra a ditadura presente na imagem de Dilma Roussef (embora sem o mesmo impacto popular), passa a compor o imaginário não mais da perspectiva da luta social, mas da vitória de um processo, agora, contudo, esvaziado de seu sentido combativo.

abertura da Copa do Mundo FIFA de 2014, com enorme financiamento por parte do governo federal, o que gerou muitas críticas tanto devido ao enorme montante destinado à construção da arena, quanto pelas denúncias de más condições de trabalho dos envolvidos com a obra.

26 Minha casa, minha vida" é um programa "lançado em março de 2009 pelo Governo Federal. O PMCMV subsidia a aquisição da casa ou apartamento próprio para famílias com renda de até 1,6 mil reais e facilita as condições de acesso ao imóvel para famílias com renda de até de 5 mil reais. 


\section{30 mundo do trabalho}

Atílio e Elisinha são trabalhadores representantes do "povo" e do Timão. Atílio é um operário que sabe tudo sobre a trajetória do time "e quase nada de todo o resto" e Elisinha é a "fiel torcedora, símbolo do Corinthians" (BRAVA COMPANHIA, 2015, p. 207), que consegue relacionar a trajetória do time a algumas dimensões de sua experiência material e histórica. A importância dos dois personagens diz respeito à composição ambígua por meio da qual se dá o mundo do trabalho na periferia. Como já observamos, o processo migratório do campo para a cidade paulatinamente deslocara para os centros urbanos uma ampla gama de trabalhadores em busca de emprego e, na mesma proporção, o mercado informal ganhou enorme importância como forma de subsistência da população periférica.

Eder Sader (1988) descreve que a ordenação social mediada pelo trabalho passaria a ser questionada já no início dos anos de 1970. Citando um texto mimeografado intitulado "Uma experiência junto ao proletariado", escrito em 1972 por um jovem metalúrgico e militante que trabalhara em indústrias do $\mathrm{ABC}$, Sader nota que, antes de falar da fábrica, o autor ressalta a significação subjetiva do desemprego, já presente a partir de 1968 , posto que

O desempregado fica totalmente desvinculado do seu meio. Se sente desmoralizado diante da família, diante dos vizinhos e diante, enfim, da sociedade. Nas conversas se pode sentir isso, e alguns preferem ficar gastando os seus últimos cruzeiros em bares do que voltar para casa e sofrer a pressão da família”. Sente-se aí como a desmoralização sofrida esta no âmago de uma identidade construída do trabalhador honesto e responsável, que assegura o sustento da família e tem lugar na sociedade. (TORRES apud SADER, 1988, p. 70).

Dando sequência ao argumento, Sader (1988) descreve que, em face do problema do desemprego, surgiria também, entre aqueles que compartilhavam dessa mesma situação, uma nova solidariedade que, contudo, desaparecia diante da concorrência do mundo do trabalho e no eventual caso de reintegração ao emprego. Associado a esse cenário, parte significativa desses desempregados apenas conseguia subsistência ao integrar-se ao setor de serviços, em microempresas, ou como autônomos, muitas vezes sem registro. Essa é uma das realidades do mundo do trabalho no período, e daí viria a emergir parte das organizações sociais e políticas do período 
que compuseram a Nova Esquerda. Uma parcela significativa dos trabalhadores era formada por migrantes vindos do campo para a cidade e que se viam destituídos de suas identidades culturais ou de seus saberes, posto que esses conhecimentos não contribuíam para a reprodução econômica no meio urbano.

Por sua vez, dentro das fábricas, a organização política também se forjava a partir de novos pressupostos. As lutas encampadas por esses agentes adensaram o processo de organização, sobretudo porque "seus expoentes conseguiram explorar brechas legais, objetivos e formas de ação considerados legítimos para defenderem os interesses dos associados, embora nesse processo tenham tido, afinal, de se contrapor às autoridades" (SADER, 1988, p. 182). Tendo por base a integração na cadeia produtiva e um enorme poder de barganha com relação à institucionalidade estatal, foi, principalmente, devido a esse lugar de fala que conferia legitimidade às suas demandas que o movimento teve condições de "interpelar as mentalidades formadas pelos discursos dominantes" (SADER, 1988, p. 184).

Embora a descrição de Sader corresponda ao cenário político da década de 1970, essa mudança no tecido urbano já esta representada pelo Corinthians, meu amor de César Vieira. O autor parte de uma observação atenta à realidade social dos populares e registra em sua dramaturgia essa transformação da sociabilidade urbana no calor dos acontecimentos. Elisinha e Atílio, já aparecem no texto original. Elisa é apresentada como "uma negra, turbante na cabeça, impassível" (VIEIRA, 2008, p. 57), que vende pipoca e carrega um enorme distintivo do Corinthians no peito. Atílio, na mesma cena, se aproxima do carrinho com um grupo de "amigos do mesmo bairro, talvez da mesma fábrica, do ponto comum do bar da esquina. Toda a defesa do time de várzea da rua" (VIEIRA, 2008, p. 58), ainda vestidos como operários. No desenrolar do texto de César Vieira passamos a acompanhar as situações vivenciadas por esses dois personagens e percebemos neles a enorme solidariedade com relação a todos os demais interlocutores.

Embora seja um operário, Atílio, no texto original, demonstra uma atitude afetiva com o patrão, aparecendo como um personagem despolitizado, a despeito da sua possibilidade de organização política via sindicato:

Por entre figurões de casaca, mulheres de vison. Atílio e Jesuh ouvem o orador, apertam os lábios.

- "chorar a sua inestimável perda..." (Repetindo a fala do orador). Nunca vi esse cara. 
- É... mas era o patrão.

Jesuh resmuunga:

- Eu não queria vir... mas disseram que iam descontar o domingo...

Atílio responde com raiva

- Iam? De mim ninguém ia descontar nada.

- Machão, heim? Mas veio, né? (VIEIRA, 2008, p. 80-81).

Já Elisa, a camelô, é marcada por traços que a vinculam à cultura negra, e dispõe exclusivamente da generosidade na relação com os demais populares, embora não tenha condições de se organizar efetivamente. Elisa é a porta voz do discurso da peça e representa, também para César Vieira, o desejo de uma sociedade sem hierarquias e com direitos iguais para toda a população:

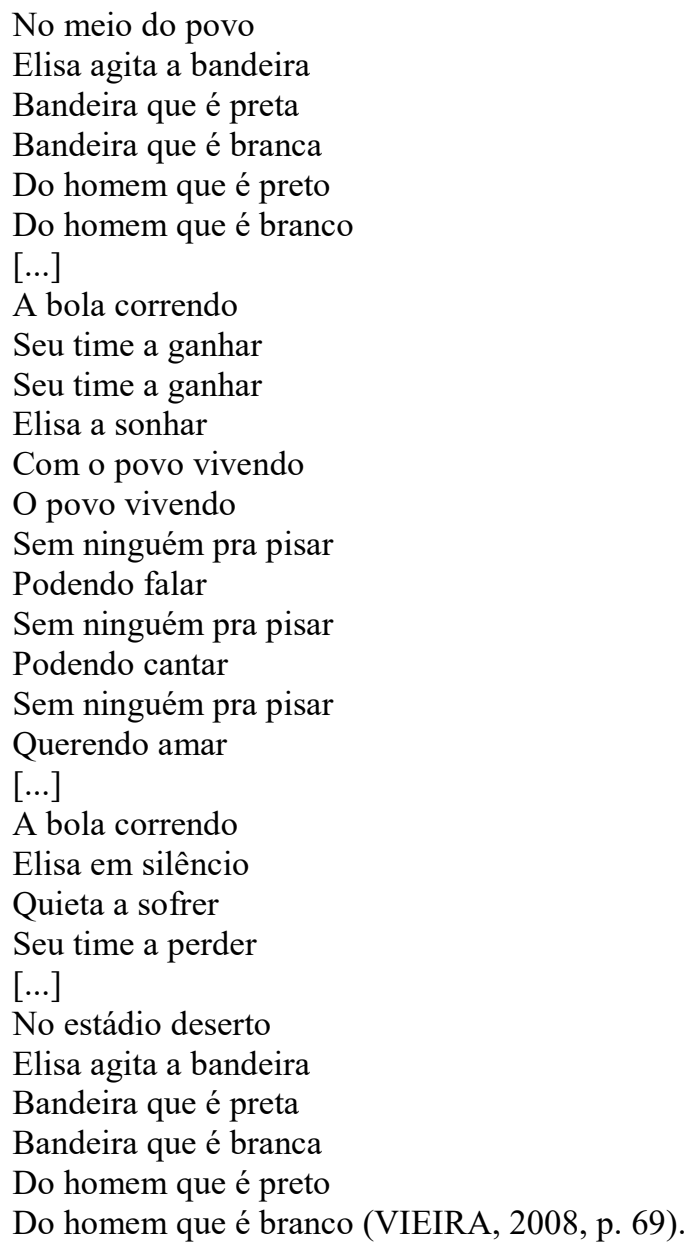

A música, que é a bandeira do espetáculo de César Vieira, é seguida por uma cena na qual vemos Elisa e mais um camelô disputando clientes em um comício político ao lado do Monumento à Independência. "Pipoqueiros, curiosos, mulheres da vida, tiras em profusão, camelôs em dia pouco propício" somam-se a estudantes, funcionários da 
CMTC (Companhia Municipal de Transportes Coletivos), padres e um tipo barbudo, misto de Jesus com Che Guevara. Eronides, o intelectual da Brava Companhia, é para César Vieira um estudante ativista na militância que, ao se aproximar do carrinho do camelô concorrente de Elisa constata que não tem dinheiro suficiente para comprar a pipoca. A pipoqueira, então, decide dar a ele um pacote de amendoim, percebendo as dificuldades financeiras atravessadas pelo rapaz. Como um agrado à vendedora, Eronides retribui com um anel no qual há o distintivo do time do Corinthians, o que premia a atitude solidária da popular.

Tendo em vista os contornos propostos por César Vieira aos dois personagens, torna-se mais evidente a interpretação proposta pela versão da Brava Companhia. Embora a peça original coloque em cena diversos lugares na cadeia produtiva, como representantes do operariado e do trabalhador informal e precarizado, o lugar destinado a ambos pela encenação contemporânea não os insere no contexto de suas práticas no mundo do trabalho, mas na forma como ambos empregam o seu tempo livre no boteco de Olho Vivo. Associa-se a isso a maneira como a relação com o time do Corinthians determina, para ambos, formas bastante distintas de compreensão do popular e a formulação distinta de suas atitudes solidárias.

Nesse sentido a personagem da Brava Companhia, Elisinha - uma espécie de diminutivo que está atenta apenas a uma parte da complexidade da "Elisa" de Cesar Vieira - Ainda que tente, no momento da apresentação dos personagens da Brava Companhia, vender o seu "churrasquinho de gato" para os frequentadores do boteco, o gatinho preto que a torcedora carrega nos ombros permanece vivo, fazendo com que esse Gestus da negociação mercantil não é a marca da sua relação com o público. Ao contrário disso, é em uma cena coletiva que a personagem assume a palavra e dá início a um ritual de "renovação e reafirmação de votos" (BRAVA COMPANHIA, 2015, p. 210) com o popular. Já Atílio, que terá papel central na cena "Santo Tino" (cena esta que opera na estrutura dramatúrgica como um contraponto direto à cena citada acima), é apresentado quase sem contornos por meio de um Gestus sempre inseguro e ingênuo, mostrando dúvidas sobre aquilo que sabe acerca de seu próprio processo histórico, embora seja um fiel e ardoroso torcedor do time.

Evidencia-se na participação desse duplo popular a configuração do mundo trabalho e, sobretudo, das lutas populares, assumindo-se uma perspectiva nova, na qual 
é o uso do tempo livre e não dos seus lugares sociais na cadeia produtiva que poderá sustentar uma nova possibilidade de organização. O limite imposto ao problema tornase evidente na conjunção de suas aspirações populares, completamente subjugadas pela identificação única e irrestrita com uma única matriz discursiva, o time do Corinthians, e que os impede de analisar criticamente até mesmo os problemas que eles são capazes de perceber em suas experiências materiais. Os personagens identificam e evidenciam aspectos relativos ao campo do trabalho e às opressões vividas, mas recorrem ao glorioso ditado "maloqueiro, sofredor, graças a Deus", de cunho popular, vangloriandose da miséria sob o escudo do time.

Apresentados os personagens, o coro de populares se completa, assumindo suas diferenças de maneira gestual. Ao representar aqueles que seriam os novos personagens a entrar em cena por meio dos movimentos populares da Nova Esquerda problematizando alguns aspectos já prementes no momento da formação dessa frente, mas que se tornaram ainda mais relevantes passados pouco mais de trinta anos -, a homenagem reconhece, sobretudo, a enorme importância desse processo de militância e luta. Seja no sentido de reconhecer nesse movimento os fundamentos das políticas públicas dos últimos anos, seja para que tenhamos condições de pensar novos rumos para a mobilização e para a luta contra esse sistema, o período é central dada a emergência desses novos atores sociais (com suas novas demandas materialmente implicadas na reprodução da sociedade), que outorgavam uma possibilidade de Estado democrático e igualitário. A atenção maior dedicada pela Brava Companhia ao duplo que se relaciona com os processos culturais advém do ponto de vista organizativo instaurado por Olho Vivo, apontando que a perspectiva de um teatro militante em curso na periferia seria o melhor lugar de onde narrar os impasses do período. Aqui, concordamos com Tiarajú na proposição de que o front cultural parece ser um dos poucos espaços onde ainda se busca coordenar alguns discursos combativos que façam frente ao sistema social. A expectativa da Brava Companhia, nesse sentido, é de contribuir para que seu lugar artístico militante se expanda e possa agir em direção às transformações que urgem em nosso tempo.

Manter a atenção do espectador no Gestus dos personagens, e não na inquietação acerca de seus objetivos ou razões subjetivas, contribui, assim, para deixar uma lacuna para o espectador que pode ser preenchida com a sua própria experiência de vida e 
militância. Também é nesse espaço que nasce a crítica aos processos, pois o espectador é capaz de observar avidamente e tecer suas próprias considerações sobre os movimentos da história, implicando-se na sua compreensão. A música que encerra a cena é um hino à ação do Teatro Popular União e Olho Vivo que reforça o tom da homenagem e evidencia o sentido almejado pela companhia de atenção crítica. Não é a união popular abstrata que balança a Bandeira da Brava Companhia, mas é o reconhecimento das condições concretas de uma sociedade opressiva que tece as balizas para uma efetiva união:

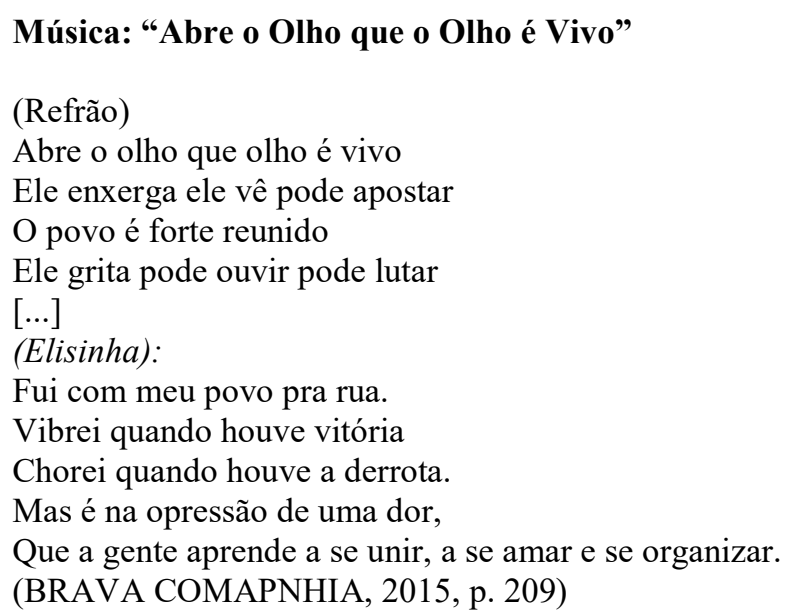

A música Abre o Olho que o Olho é Vivo desemboca em uma nova tentativa de organização, que mais uma vez é frustrada por um lance do Timão no rádio do boteco. Retomando a centralidade da personagem Elisinha, a Brava Companhia a representa assumindo uma diferença fundamental com relação à versão original, na qual Elisa é uma torcedora idealista e sonhadora, esperando algum dia ver seu time podendo lutar, falar e amar. Já para a Brava Companhia a personagem possui uma outra consciência, histórica, que faz com que seja capaz de aprender, de se unir, de se organizar e também de amar, por meio do reconhecimento da opressão. Sendo assim, diante de mais uma derrota popular, na cena 3, o grupo propõe um ritual de renovação de votos, o grupo, mais uma vez, convida o público a participar da luta popular.

A personagem Elisinha, em parceria com Eronides, comanda mais ativamente o ritual, ainda que todos os populares participem da paródia. Atílio abre a cena relembrando alguns dados que compõem o imaginário popular sobre o Corinthians e que ressaltam a importância do time na sociabilidade popular. O aumento de produção 
nos dias de vitória e o aumento dos acidentes de trabalho nos dias de derrota são dados contrapostos pelos personagens para demonstrar a influencia do time na realidade material. Embora estatisticamente comprovadas, as informações são apresentadas de maneira a explicitar uma lógica religiosa e mitificante presente no enunciado, como se isso estivesse associado a uma preferência dos deuses em relação ao time. Atílio presenteia Olho Vivo com uma placa, feita por ele mesmo, onde há escrito os seguintes dizeres: "O Corinthians não é um time, é uma religião". O presente incita Olho Vivo a colocar ao lado desta uma segunda placa com o texto marxista "As religiões nascem de um mito ou da magia", contrapondo o argumento de Atílio ao ressaltar que os mitos e a magia nascem de tudo aquilo que não conseguimos entender. Cria-se uma oposição, portanto, ao sentido que está sendo dado pela Brava ao Corinthians, posto que o grupo se dedica a compreender a importância do time assumindo uma perspectiva histórica.

Reforçando esse sentido, antes de ter início a paródia de um rito corintiano, Olho Vivo justifica aos presentes que ali há muita gente que torce para outros times e, impedindo que Elisinha queime fotos e símbolos que remetem a outros times, o Coringa relembra que, antes de tudo, os reunidos ali são povo. Essa intervenção muda o rumo do ritual, já que, se em um primeiro momento eram queimados os inimigos do Corinthians, a partir daí, imagens de políticos reconhecidamente demagógicos e avessos ao povo passam a ser queimados. Mais uma vez as formas populares e carnavalizantes são o recurso adotado pela Companhia para estabelecer uma relação de interlocução direta com o público. O uso de máscaras de poderosos, paródias musicais e a recorrência de símbolos de uma ritualística pagã, como o fogo, são indícios de um diálogo com a religiosidade que não leva a serio as suas hierarquias. Instaura-se, a partir de então, uma participação mais ativa e jocosa na relação com o público.

A relação que estabelecemos entre a participação do público e uma aprendizagem acerca do olhar crítico vai em sentido oposto à tendência de participação do público criticada por Anatol Rosenfeld em seus escritos sobre o Teatro Oficina, ou o Living Theater, publicados no livro Texto/Contexto I (ROSENFELD, 1996b). Nesses casos, a participação do público, além de pressupor o engajamento físico dos envolvidos, implica em engajamento subjetivo com a cena, através da adesão a comportamentos e compartilhamentos comunitários. Por vezes, ao recorrer à ritualização para produzir a participação e o engajamento do público, o teatro, 
problematicamente, já se bateu contra questões éticas e discursivas que reconheciam um grau de violência e gratuidade na obrigatoriedade da participação, o que dificultaria a apreciação crítica do objeto representado.

Por outro lado, o reforço sistemático de que o público apreenda os Gestus dos personagens por meio da paródia e do riso não repercute em violência de exposição dos indivíduos, mas na crítica do Gestus que é representado, ou seja é o Gestus presente na imposição à participação que fundamenta a cena. O ritual de filiação que se segue, ainda que exponha o objetivo comum naquele encontro que se instaura, ou seja, a luta, o faz de modo a parodiar a dimensão espiritual que a antecede, propondo uma crítica ao engajamento irrefletido relativo aos processos sociais e históricos. O alvo dessa crítica, por sua vez, não é o público, mas os personagens que tentam obrigá-lo a integrar a coletividade.

Elisa - Bom, temos aqui esta pessoa que nos procurou desesperadamente porque quer se converter, quer mudar de lado e fazer parte do nosso bando (mostrando o bando do outro lado, formado pelos personagens da peça). Então vamos à 1a etapa: Você quer fazer parte da nossa história, não é?

Eronides - (Com participante do público). Sim!

Elisa - Você tem consciência da importância de se assumir como fazedor(a) de história?

Eronides - Sim!

Elisa - Tem consciência de que nóis tamo aqui unidos em prol de um só objetivo? Eronides - Sim! Sim! Ele(a) tem sim!

Elisa - Então vamos à 2 a etapa: a hora da virada! O chão aqui tá riscado! (Risca o chão). A escolha é sua! Ficar aí desse lado ou vir pra cá e somar na luta com nóis! (Pausa. Os atores da peça estão se batendo atrás). Sai desse lado, porra! (Música, travessia para o outro lado). Espera! Você tem certeza? 3a etapa: É hora de se desapegar dos bens materiais e contribuir com a nossa taxa de filiação! (É feita uma revista no participante). Batiza! (Ator aponta pistola de água e espirra água). A partir de hoje não haverá mais solidão, fazemos parte do mesmo bando. (Participante senta do outro lado. Finalização da música com Eronides e Atílio - Elisa interrompe). Parou! Bom, vamo lembrar um pouco da nossa história. Vamos lembrar que o momento em que mais crescemos e se unimo como fiéis foi um momento muito duro, em primeiro lugar por causa da ditadura militar e em segundo lugar, porque nóis tava num jejum de 23 anos sem ganhar nenhum título! Mas foi aí que aprendemos a se organizar! Timão êô? (BRAVA COMPANHIA, 2015, p. 213)

Apenas as perguntas feitas ao público pela personagem Elisinha são significativas para a apreensão crítica da cena. As suas respostas, por sua vez, sempre revelam o erro e a farsa do processo, demonstrando o risco implicado em uma narrativa autoafirmativa provinda de uma identidade com o time. De partida, as perguntas "você 
tem consciência da importância de se assumir como fazedor de história?" e "Tem consciência de que estamos aqui unidos em prol de um só objetivo?" (BRAVA COMPANHIA, 2015, p. 213) são feitas para um "fiel”" que não tem chance de respondêlas, já que Eronides, o intelectual, toma a cabeça de um participante e a manipula fisicamente, impondo uma resposta positiva. Na hora da virada, a personagem risca o chão, apresentando a possibilidade real de escolha para o público: "A escolha é sua! Ficar aí desse lado ou vir prá cá somar na luta com nóis!" (BRAVA COMPANHIA, 2016, p. 213). Atenta ao fato de que a pergunta não pressupõe resposta imediata por parte do público, a peça encaminha-se no sentido de apresentar os impasses de tal associação, demonstrando o desespero, as brigas, e evidenciando que, internamente, há desavenças entre os correligionários. Quando o participante finalmente se une ao grupo, outros procedimentos religiosos, como o dízimo e a bênção, que correspondem à violência dessa união imposta, são apresentados e a cena é coroada pela canção Amigo de fé, de Roberto Carlos, cantada de forma desafinada pelo bando, o que parece constituir um procedimento paródico.

A predileção pela paródia religiosa fricciona os temas e, neste ponto, o rito remete mais à violência dogmática do que à afinidade espiritual com o Corinthians. Como já mencionamos, também no prólogo o grupo faz uso de suas formas ao apresentar uma maneira fluida de sobreposição de divergências que leva a uma afinidade irrevogável com o popular. Aqui, no corpo do problema, esse coro desafina em relação à ação impositiva de um mito unificador que conferiria às subjetividades um acolhimento em bando. Mais uma vez a ação historicizante remete à união catalisada (violentamente) pela ditadura a partir da experiência de sofrimento compartilhado, que volta a ser narrada e associada à história corintiana.

A Contradição apresentada pela cena, por meio da contraimagem explorada pela Brava Companhia, dá a ver de maneira precisa a violência presente nos espaços onde não há luta, ao mesmo tempo em que expõe "a luta" como uma possibilidade de reconhecimento e agregação pautada pelo processo histórico. Converter-se à luta não é um ato religioso, ainda que a cena trabalhe nesse limiar; tampouco é possível fazê-lo mediante pressupostos que se baseiem em laços espirituais mitificados, mas sim segundo o pressuposto de reconhecer-se como sujeito histórico a partir de suas implicações materiais. Essa ambiguidade propositalmente instaurada pela cena acaba 
por evidenciar a violência implicada em coletividades forjadas a partir de laços abstratos e reificados, que, a despeito da validade de seus conteúdos, agridem pela forma com que eternizam seus dogmas e procedimentos.

Eder Sader (1988), para descrever a constituição dos personagens que compõem a esta nova configuração da esquerda, ressalta:

\begin{abstract}
Não se trata de alguma suposta identidade essencial, inerente ao grupo e preexistente às suas práticas, mas sim da identidade derivada da posição que assume. Tal identidade se encontra corporificada em instituições determinadas, onde se elabora uma história comum que lhe dá substância, e onde se regulam as práticas coletivas que a atualizam. Quem são os sujeitos em questão? São membros de um sindicato? Militantes de um partido? Participantes de uma comunidade de base? (SADER, 1988, p. 43-44).
\end{abstract}

E nós acrescentamos: São artistas? Produtores culturais?

A personagem Gabriela retorna ao foco quando Elisinha interpela os populares sobre quem seriam aqueles indivíduos - assujeitados - sem o Corinthians, já que o Corinthians, sem eles, ainda existiria. A pergunta retórica é, simultaneamente, uma pergunta crítica, posto que associa, dialeticamente, alienação e individualismo. Quando Gabriela responde seu nome, Elisinha responde "não, você não é ninguém! Humildade, minha filha" (BRAVA COMPANHIA, 2015, p. 214). O "ser ninguém" a que se refere Elisinha diz respeito à individualidade reivindicada pela personagem burguesa frente à união popular, ao mesmo tempo em que nos interpela com a anulação da sua subjetividade e da dos demais presentes diante da força mítica do Corinthians. As práticas representadas no rito corintiano são também contraditórias e, embora articulem retoricamente valores que dão sentido à existência do grupo, não são práticas políticas que pressupõem uma ação de transformação social.

Nesse sentido, os pregadores acabam por incorporar Gabriela à coletividade e é no Gestus de Gabriela que observamos a transformação da experiência popular em imagem espetacular reificada. A personagem, durante o ritual de conversão ao popular/corintiano, faz gestos estilizados de maneira estereotipada, que remetem a danças afro-brasileiras e, ao perceber que a pessoa do público que ficara responsável por filmar não estava atenta ao registro, interrompe decepcionada o show. A paródia do ritual, portanto, apresenta o processo de separação entre identidade e processo histórico que implica o conceito de popular (lembrando mais uma vez que o Corinthians é uma 
metáfora para esse conceito). Ao flagrar a ambição da personagem em "dar o furo", projetando sobre si a autenticidade da cultura popular, o Gestus idealista da personagem acaba por revelar que seu olhar não se integra à luta, ainda que ela participe daquela coletividade. Com isso, a personagem realça a contradição inerente à situação, posto que aquela forma de organização permite a ela agir no sentido de mercantilizar suas dimensões mais sutis.

Essa separação viria a turvar a visão sobre as condições objetivas de produção dessa coletividade, exigindo a imutabilidade mítica dos seus paradigmas para que haja integração à fantasmagoria do espetáculo. Dessa forma, uma vez que "a constituição histórica das classes depende da experiência das condições dadas, o que implica tratar tais condições no quadro das significações culturais que as impregnam” (Sader, 1988, p. 43-44, grifos do autor), mesmo as referências ao popular e à luta presentes na cena operam como problemas à organização, e não como caminhos para uma efetiva mobilização.

A imagem eternizada pela máxima corintiana "maloqueiro, sofredor, graças a Deus" (BRAVA COMPANHIA, 2015, p. 217) se transforma em hino litúrgico, e na eucaristia vemos o suor e o corpo dos jogadores convertidos em amendoim com cerveja. A representação remete ao pão e circo, sem deixar de fazer menção aos gladiadores postos em sacrificio. Olho Vivo questiona o porquê da identificação com o sofrimento e, enquanto a canção "Comportamento geral", de Gonzaguinha, rememora as mazelas sociais, o Coringa pede ao público para que a indignação possa ser "combustível de mudança": não graças a Deus, mas graças a nós. (BRAVA COMPANHIA, 2015, p. 217) O personagem, então, distribui ao público instrumentos musicais no intento de retomar a roda de samba do início do espetáculo com uma nova canção, que pinta a favela como um "inferno colorido" pela mídia e pelo Estado.

\section{4 É pelo trabalho que eles não se reconhecem}

$\mathrm{Na}$ sequência, temos a primeira intervenção da polícia nas tentativas de organização popular. Ainda que as tentativas anteriores tenham sido igualmente frustradas, isso se dera pela ação dos próprios personagens e não por qualquer agente 
externo. Com a primeira passagem de Moacir pelo boteco, começamos a apreender a interferência institucional no quadro, ainda que a cena apresente isso mantendo o olhar fixo no Gestus do personagem. Moacir é um policial que está há duas noites sem dormir, somando turnos de trabalho, e que também se encontra sob acompanhamento médico-psiquiátrico. Ao adentrar o espaço como representante da ação violenta da polícia, agindo sobre o contexto periférico e das organizações populares, o personagem revela o problema de uma total desvinculação de sua realidade de classe, posto que a sua ocupação no mundo do trabalho é reprimir os seus iguais.

Representada, por sua vez, de maneira cômica, a cena revela a arbitrariedade das suas condutas, já que, se inicialmente o personagem inquire Olho Vivo sobre o alvará de funcionamento, IPTU, contas de luz, vigilância sanitária e outros atributos legais que autenticariam a continuidade das atividades realizadas no espaço, subsequentemente, outras siglas descontextualizadas demonstram que a busca ali tem outra finalidade, resultando na autuação do estabelecimento. Mesmo sendo velho conhecido do dono do boteco, ele inicia a tradicional revista policial, com o perdão do trocadilho, pedindo a colaboração dos frequentadores do espaço para que o número teatral termine bem.

Se esbaldando nos pequenos poderes para se divertir com a humilhação de alguns, Moacir segue com a revista de modo a tornar todos os presentes suspeitos quando, em uma escuta com a chefia, alguma característica comum, como "ele veste calça jeans" é associada a um elemento de alta periculosidade. Isso remete o público diretamente ao lugar de justiçamento e desconfiança seletiva que recai sobre negros e pardos na periferia. Um participante é abordado pelo policial com o fim de revelar a costumeira violência e agressividade de suas práticas, ainda que o personagem afirme que fará o procedimento "conforme o treinamento da academia, de forma discreta, cordial e muito bem educada. Dirige-se para a pessoa do público descrita e grita agressivamente: De pé, cidadão! De costas! Documento!”. (BRAVA COMPANHIA, 2015, p. 221) Para encerrar a cena, o palhaço Carne Moída intervém de maneira humorística, fingindo ser o chefe que, com o megafone, informa que as atividades do policial são requisitadas em outro estabelecimento, com urgência. A interrupção permite a finalização do quadro, que conta com a memorável despedida de Moacir a nos lembrar que "a polícia está sempre a postos para proteger e servir os cidadãos de bens" (BRAVA COMPANHIA, 2015, p. 222). 
As piadas infames mantém sobre a figura do policial o foco de ridicularização e desdém que também protege o público de uma interação efetivamente violenta. $O$ recurso cômico que, mais uma vez, ameniza a violência da relação acaba soando ingênuo diante do problema efetivo implicado nessa ausência de consciência de classes por parte dos populares que integram os quadros da polícia militar, já que, na base dessa contradição, também figura hoje a ação das milícias de extermínio e o tráfico institucionalizado. Nessa passagem, os trocadilhos como "a coxinha com café" e a "amizade" entre Moacir e Olho Vivo, do qual o policial se esquece, dão a ver a fragilidade da pessoa em serviço, e não sua autoridade fortalecida como instituição de vigilância. Todavia, na segunda parte da peça, quando as contracenas buscam aprofundar-se na totalidade desses Gestus, os desdobramentos da cena demonstram algumas das suas implicações com o campo institucional, no qual a referência à ação violenta do Estado aparece de maneira mais complexa em sua relação direta com a mídia. 


\section{Do épico à peça de aprendizagem - um problema de representação}

Reconhecemos que o trabalho de Brecht passa a orientar a produção teatral brasileira a partir dos anos de 1960, enraizando-se em nossa tradição literária, sobretudo nas práticas engajadas politicamente. Em 1986, José Antonio Pasta publica um importante estudo sobre o dramaturgo, $O$ trabalho de Brecht, que reorienta as leituras acerca de suas proposições estéticas, apontando para o valor coletivo como o cerne de sua produção (PASTA, 2010, p. 86).

\footnotetext{
Brecht dizia, da "experiência sociológica", que se tratava "quase, no sentido próprio, de um processo de pensamento", para acrescentar ao final do trabalho: "é preciso agora métodos de discussão que sejam em uma medida mais larga semelhantes a processos de pensamento coletivo" (BRECHT apud PASTA, 2010, p.102).
}

$\mathrm{Na}$ coletividade representada em Corinthians, meu amor: segundo Brava Companhia, podemos observar as formas com que os diversos personagens e o público se relacionam nesse encontro, tendo em vista um circuito cultural formado, principalmente, por integrantes de grupos de teatro engajado da cidade de São Paulo, de coletivos culturais da periferia e de movimentos sociais, além de estudantes e professores mobilizados pelo interesse na teoria crítica, e de alguns moradores do bairro. São esses os atores sociais inscritos no processo histórico representado e é essa a realidade sobre a qual se debruça o trabalho do grupo. O lugar ocupado dentro do aparelho produtivo é determinante para suas proposições formais e, quando conjugado ao seu lugar político junto à comunidade, projeta um alargamento nessa coletividade e na própria concepção de produção cultural, que se revela como "um domínio que não é separado das demais formas de produção social" (PASTA, 2010, p. 111).

Tendo isso em vista, a Brava Companhia propõe formalmente a ideia de que o público integra aquela coletividade, compartilhando, portanto, interesses comuns. Essa característica é evidenciada na narração que apresenta a escalação do jogo: "Estão de um mesmo lado o público e os artistas deste espetáculo que jogarão no limite de seus saberes até o tilintar do apito final" (BRAVA COMPANHIA, 2015, p. 201) - um jogo de futebol que é, paradoxalmente, composto apenas por um time e que reflete a ausência de antagonistas no corpo da obra, instaurando uma única ação coletiva. Os lances a 
serem investigados, portanto, fazem parte de um embate que se dará em relação a uma posição externa à narrativa, e a estratégia do jogo subjaz no estudo de um processo histórico que separa a peça da Brava Companhia da obra original. Assim, "a situação histórica da época em que a obra foi escrita, a natureza particular do autor e a perspectiva que adotou" (PASTA, 2010, p.132) se colocam à disposição da coletividade presente para uma revisão das estratégias de jogo.

As situações representadas possuem uma referência clara no texto original, e a contraimagem surge para compor o quadro, organizando as contradições que serão "estudadas" coletivamente. Cada personagem tem por base um possível integrante desse público projetado pelo grupo, tendo em vista que o objeto de análise crítica do espetáculo é a própria coletividade e suas possibilidades de mobilização política. Essa proposta busca restabelecer o pacto entre luta política e cena, vislumbrando um papel ativo em sua construção.

Dada a sua experiência no Sacolão das Artes e o envolvimento de seus integrantes com movimentos de militância e organizações culturais da cidade, o grupo possui um ponto de vista privilegiado para apreender nuances acerca da representação do popular que por vezes escapam a um olhar desimplicado ou, ainda, excessivamente identificado com um ponto de vista único. Sob a premissa de considerar diversos pontos de vista a respeito de um mesmo objeto, a constituição da contraimagem se expande sobre quase todos os elementos de cena, sobrepondo imagem midiática ou fetichizada e imagem crítica, quase sempre histórica e social.

Para Marilena Chauí, na introdução ao livro Videologias (BUCCI; KEHL, 2004), a operação realizada pela televisão brasileira vai em sentido contrário daquilo que propõe o recurso da contraimagem. Mitificando as imagens do real, a representação televisiva acaba por provocar uma inversão simplista entre realidade e ficção. Por estarem inscritas no registro do entretenimento, ambas aparecem de maneira difusa, fazendo com que nos noticiários tenhamos a sensação de estar diante de uma ficção e, nas telenovelas, acreditemos estar diante do real representado. Essa operação obtém como resultado a produção de um espelho "no qual acreditamos estar refletida nossa imagem" (BUCCI; KEHL, 2004). Ainda que nenhuma das formas representadas corresponda à nossa experiência concreta dentro do campo social. Com isso, a representação feita pela televisão brasileira, bem como pela cultura midiática de 
maneira mais abrangente, suprime o espaço do real e da ficção, produzindo, como consequência, um espaço público rebaixado, onde não há possibilidade de participação real na vida pública.

Corinthians, meu amor - segundo Brava Companhia busca criticar esse "espaço público" produzido pela indústria do entretenimento, contrapondo-o a outro espaço possível, pensado por Eugenio Bucci como a designação de

[...] um campo gerado pela comunicação social [...] [que] nasce à medida que surge o debate público. Mais precisamente: a esfera pública burguesa só se torna realidade historicamente possível quando ganha vida como função comunicativa entre os sujeitos que nela tomam parte (BUCCI; KEHL, 2004, p. 232).

Isso pressupõe a contraposição entre pontos de vista, exposta no âmago dos personagens, bem como a possibilidade de identificação e distanciamento do público em relação a diferentes formas sociais a fim de se compreender a dimensão contraditória implicada em cada uma delas, almejando-se, por essa via, uma síntese crítica e com possibilidades de atuação fora do campo representacional.

A análise que se seguirá tem em vista a apreensão dos Gestus que se contrapõem na produção desse espaço público, sem ignorar que a subjetividade implicada nessa construção constitui-se a partir da interação com uma sociedade espetacularizada e também com suas instituições. Esse espaço público, que é inexistente, apenas pode ser imaginado por meio da contraimagem, ou seja, é na lacuna produzida entre imagem 1 (composta pela imagem espetacularizada de um espaço onde poderia haver amplo debate, mas não há) e imagem 2 (representando a própria função comunicativa e do encontro, calcada em modelos históricos diversos que fomentariam uma ação contrária) que algo novo poderia surgir. Desse modo, para compreendermos a disputa em jogo dentro da peça iremos diferenciar "Primeiro Tempo" e "Segundo Tempo" a partir do corte formal proposto para cada um deles. Daremos alguns saltos que rompem com a linearidade da narrativa e que, no entanto, parecem organizar a sua totalidade tendo como base a diversidade de práticas culturais presentes na periferia.

A primeira e a última cena do "Primeiro Tempo" centralizam o conflito dramático em torno do qual se organiza a narrativa, já que as demais situações não possuem relação de causalidade interna e são, antes, fragmentos épicos que já foram 
analisados por este trabalho. A função dos diversos fragmentos é de configurar o coletivo e mostrar a estratégia de jogo de cada um de seus integrantes, ou seja, o Gestus.

Já no "Segundo Tempo", uma competição de fato tem início, e o embate entre os personagens passa a ser alegorizado quando outras instituições entram em campo. $\mathrm{O}$ objetivo é demonstrar a ação dessas instituições com vias a explicitar os mecanismos de poder utilizados por elas na produção de relações sociais desiguais. A formulação estética segue sem fazer uso de antagonistas ou protagonistas, mas as situações passam a revelar de maneira mais latente os conflitos entre eles: um novo jogo onde há interesses diversos entre os populares.

A principal instituição que "invade" o boteco do Olho Vivo é a indústria cultural, e é por intermédio da sua ação que os populares passam a participar desse novo jogo de cena em que estão todos contra todos. Por fim, a peça exibe uma cena que representa, por meio de um jogo de futebol, uma alegoria da luta de classes: o jogo final entre Elite Sport High Society e União Popular Futebol Crubi, embora os jogadores sejam apenas aqueles mesmos populares que acompanhamos durante todo o espetáculo. E a hora é de riscar o chão e ver quem é quem no "Campo do Capital".

O primeiro conflito da peça, a inviabilização da reunião com a militante comunitária graças ao desejo dos frequentadores do bar de assistir ao jogo, seguido pelo impasse gerado pela ausência do televisor, nos coloca diante da dificuldade de organização popular, tendo como contraimagem o engajamento efetivo dos mesmos populares com a cultura de massas. Ao soar o apito que dá início ao jogo, os elementos de cena estão colocados apresentando uma disputa entre "técnicas" distintas, que se travará no corpo do espetáculo. Por meio da técnica do rádio, retomada de um passado para instaurar um estranhamento na relação temporal representada pela cena, todos começam a acompanhar o desenrolar do jogo cênico, provocando a convergência na ação do coro de populares. Esse fato se diferencia tanto do jogo do Corinthians, que seria transmitido pela televisão, quanto da fala da militante, calcada na oralidade da organização popular e violentamente suprimida pela expectativa de um televisor ligado e sintonizado no jogo do Corinthians. Com essa sobreposição de ferramentas formais, somos colocados diante do problema representado pela estrutura dramatúrgica tal e qual se dá de maneira subjacente nas cenas. 
A pergunta sobre o campo da comunicação social e sua mediação pela indústria cultural é colocada sem fazer uso do aparelho de televisão ou de qualquer objeto que o presentifique diretamente. A força da sua presença, já incorporada a toda sociabilidade daquele espaço, é mais bem explicitada por meio da ausência do objeto, que é substituído, por sua vez, pela representação do desejo implicado nesse mesmo objeto, ou seja, o desejo de algo capaz de organizar e fazer convergir os anseios de um grupo tão diferenciado de populares. A sobreposição das diferenças e similitudes dos personagens cria as relações necessárias para que o espaço público comece a projetar alguma forma. A peça privilegia o espaço do encontro cultural como suporte para um debate acerca das diferentes mídias e sua reprodutibilidade técnica, focando naquilo que há de mais teatral e situacional: as forças de representação dos entraves subjacentes ao conceito de popular.

A personagem da militante e a supressão da sua fala por parte dos torcedores nos demonstra aquilo que não acontecerá no desenrolar do espetáculo. Não haverá naquele espaço a organização de uma assembleia ou de um movimento social, posto que uma parte dos frequentadores não os quer. A outra parte dos frequentadores, nós, o público, somos automaticamente esvaziados do nosso papel ativo diante da situação, já que não podemos optar sobre participar ou não da reunião que estava sendo organizada, e sequer nos opor à massa de torcedores que adentra o espaço.

Além de evidenciar que a nossa passividade diante dessa imposição não é natural, mas socialmente construída, isso nos dá a ver uma segunda ausência - uma política suprimida - que fará frente aos acontecimentos. A representação da ausência de termos políticos se dá mais uma vez pelo intermédio da contraimagem: se a televisão não precisa estar presente, pois já foi completamente incorporada pelas regras da sociabilidade (por meio da identificação com objetos de desejo espetaculares), o debate político, mesmo quando tenta se fazer presente, é suprimido, tamanha é a anulação do desejo que advém desse excesso de espetáculo, embotando o vetor que nos conduziria à comunicação com o outro. Com isso, temos uma coletividade identificada seja com o time do Corinthians, como representação do povo, seja com o acontecimento teatral, como ação cultural popular.

As formas de produção de cultura parecem atravessar os quatro cantos desse campo e Corinthians, meu amor - segundo Brava Companhia se localiza bem no 
centro, onde há o confronto entre entretenimento e politização, mercado e militância, ainda que se aproxime radicalmente da militância teatral. Quando Olho Vivo narra a formação daquele "boteco", misturando as histórias da fundação do Time do Corinthians e do TUOV, o valor coletivo implicado na participação de trabalhadores na criação de ambos ganha centralidade pelo seu notório apelo popular. É a partir daí que a metáfora proposta pelo espetáculo se desenrola, remontando a um apelo saudosista de união e solidariedade entre os trabalhadores. $\mathrm{O}$ fato de serem trabalhadores e trabalhadoras os que fizeram e fazem a história do Corinthians está na base dessa identificação, à luz de pressupostos marxistas que associariam a não alienação do trabalho ao conhecimento e à participação em todas as suas etapas de produção. Quando Mara, a militante, entra em cena para apontar as razões do encontro - lutas contemporâneas, como os despejos em curso na periferia; os problemas de transporte e o custo de vida; a expropriação do tempo e o salário pouco que sobra ao fim do mês -, a falta de união torna-se o reflexo da ausência de identificação até mesmo com os direitos básicos, fazendo-se ainda mais problemática:

Militante - [...] a prefeitura despejou mais da metade dos moradores da nossa comunidade, gente! E a outra metade está aí com a cartinha de despejo na mão. E não é só aqui, não. É despejo na cidade inteira. [...] A política que existe nessa cidade é essa: limpar a cidade, varrer os pobres para debaixo do tapete. [...] A prefeitura não vai mais despejar ninguém para construir shopping, pet shop pra cachorro de burguês... estádio...nós exigimos o direito de morar aqui... [...]

(Militante fala com as pessoas sobre problemas da comunidade, necessidade de organização, etc., até a chegada da batucada da torcida do Corinthians).

Torcida - "Favela eô! Favela eô! Favela eô...", "Salve o Corinthians o campeão dos campeões eternamente dentro dos nossos corações..." (Breque da batucada) Vich! Nóis interrompemo o baguiu...

Palhaço - Mas não tem problema não...

Torcida - "Salve o Corinthians o campeão dos campeões..." (Breque da batucada)

Palhaço e Cotonete - Nóis não tamo bêbado! (Invadem o bar. Bagunça...).

Olho Vivo - Gente! Gente! Vocês sabem que é sempre uma satisfação ter vocês aqui, né... Toda vez que tiver jogo do Corinthians...

Torcida (interrompendo) - "Salve o Corinthians o campeão dos campeões eternamente dentro dos nossos corações..." (Breque dos tamborins).

Olho Vivo - Rapaziada... Isso é uma falta de respeito! Não vamos sujar nossa camisa...

Atílio - É... Nossa camisa... do Corinthians!

Torcida (cantando e tocando) - "Salve o Corinthians..." (Olho Vivo apita.

Param de tocar.)

Olho Vivo - Que é isso?! Que falta de respeito é essa?! Eu emprestei o bar pra comunidade porque tá acontecendo uma merda aqui na nossa cara! A prefeitura tá mandando todo mundo embora! Tão passando com o trator em cima da casa de todo mundo! Passaram com o trator em cima da casa da 
Dona Maria Pretinha, sua vizinha... A gente precisa fazer alguma coisa... (Silêncio total.) E outra, a televisão quebrou. Não vai dar pra ver o jogo aqui não... (Indignação total dos torcedores, grande bagunça)

Cotonete - Peraí pessoal! Peraí! Não tem televisão, mas não tem problema... Nóis vamo ver o jogo no rádio mesmo! Porque o mais importante é que nóis tamo tudo aqui, junto, unido... Nesse espaço que é o coração dessa comunidade! (BRAVA COMPANHIA, 2011) ${ }^{27}$

A história de formação da periferia da cidade de São Paulo, construída também por trabalhadores e trabalhadoras que, à margem do Estado, ocuparam os terrenos e ergueram suas casas em mutirões, é, juntamente com a história do TUOV, a contraimagem da narrativa apresentada sobre o time do Corinthians. Consideramos que essa insurgência na sociabilidade periférica de uma cidadania com novos ares que, à margem do Estado, armava barracos e criava novos bairros em busca de direitos básicos de moradia, como descreve Paulo Arantes, em "Depois de junho a paz será total" (ARANTES, 2014), associada à ação de grupos artísticos militantes que buscavam integrar as entidades e movimentos sociais nos idos dos anos de 1970, conjuga-se no ponto de vista organizativo de Olho Vivo, como descrito anteriormente. A ação à margem do sistema é tomada como um Gestus que, à distância, torna-se o princípio estético do projeto de encenação do Corinthians, meu amor da Brava Companhia. Ao assumir o desejo de retomar o espírito popular e coletivista dos mutirões de encher laje na periferia, o grupo aponta para a força motriz de ocupação desses bairros pela população pobre na mesma medida em que, ao retomar o ponto de vista de Olho Vivo, remonta à própria formação dos movimentos culturais periféricos.

Ambas as experiências, seja a do campo cultural militante da década de 1970, seja a da "cidadania insurgente", (ARANTES, 2014), permaneceram à margem nas periferias da cidade. A primeira, contudo, conecta-se diretamente com as origens da relação social que a peça busca investigar; sendo assim, ela se torna o objeto sobre o qual debruçamos criticamente o nosso olhar. A "cidadania insurgente", contudo, ainda que tenha origem no mesmo tempo histórico, é, como sugere Paulo Arantes (2014), “inusitada” para

${ }^{27}$ Para esta passagem optamos por utilizar a versão do documento cedido pela Companhia que data de 2011. Esta escolha se deu ao fato de que, nas versões publicadas, Caderno de Erros II (2011) e Caderno de Erros IV (2015), a fala da militante sofreu cortes que ocultam aspectos de maior relevância para o andamento da pesquisa. As modificações se devem à opção da encenação de convidar militantes engajados com organizações de bairro que estejam efetivamente articuladas com as lutas da região, como forma de evidenciar as lutas e a supressão das mesmas. Um segundo aspecto que precisa ser recordado é que a fala da militante, em 2011, fazia menção diretamente aos despejos em curso na região sul da cidade de São Paulo. 
compreender-se as possibilidades de política aventadas no período. Com efeito, foi apenas à luz das jornadas de junho de $2013^{28}$ que essa prática passaria a ser pensada como elemento formal da política brasileira, dada a proporção da insurgência que levou à tomada das ruas. Nesse sentido, a Brava Companhia, ao retomar o espírito de mutirão de encher laje e do trabalho cultural coletivo, cria internamente ao próprio procedimento dialético da contraimagem um novo espaço: o espaço que conduz à imaginação do futuro. Se criticamente a história de militância do TUOV faz frente à imagem espetacularizada e fetichizada que ocupa hoje o brasão do Corinthians, sobretudo no que se refere às relações com o mercado, a "cidadania insurgente" e o trabalho coletivo fazem frente ao papel do Estado como gestor, ou seja, tornam explícita a relação íntima entre Estado e mercado.

Tendo isso em vista, a fala da militante Mara nos obriga a ver o lugar ocupado pelo Corinthians de hoje - em sua forma midiática e espetacularizada - diante do Estado, criando uma oposição às formas como esse mesmo Estado age na relação com os pobres, que, na metáfora proposta pela peça, são os corintianos.

Nesse caminho, Corinthians, meu amor: segundo Brava Companhia se embate pedagogicamente com a tarefa de reconhecer no proletariado aquilo que o separa de sua consciência de classes. A peça aponta para a ideia de que, ao compor essa identidade à luz da imagem do proletariado projetada no time do povo, o envolvimento e a participação dos populares torna-se imagem espetacularizada do trabalhador e do trabalho, reproduzindo, com isso, uma ideologia que torna positiva a sua exploração. Os problemas pertinentes à sua realidade material, como os despejos, as dificuldades de mobilidade urbana, a especulação imobiliária, os despejos e a precarização do trabalho, desaparecem, e a identificação entre os pares é capitaneada pelo espetáculo, fazendo com que o maior problema a ser resolvido coletivamente seja conseguir um televisor que possibilite ao coro de corintianos assistir ao tão desejado jogo.

Em oposição a isso, a peça leva em conta alguns dos caminhos por meio dos quais se buscava estabelecer, nos anos de 1960 e 1970, uma identidade de classes

\footnotetext{
${ }^{28}$ As jornadas de junho foram manifestações populares que ocorreram por todo o país em junho de 2013. Inicialmente os protestos buscavam contestar os aumentos nas tarifas de transporte público, mas as pautas se ampliaram e se diversificaram dando início a um novo tempo na política brasileira, como se pôde observar com os desdobramentos do processo. Para maiores informações, ver: http://passapalavra.info/2016/01/97354. Acesso em: 1 jul. 2017.
} 
mediante o ideário de esquerda e suas complexas relações com o ideário de nação. A cultura, de fato, centralizava o processo e a disputa, produzindo um espaço intrinsecamente conectado entre Estado e mercado, que incluía diversos setores da população. O futebol e o time do Corinthians, nesse sentido, produziram essa identidade difusa em torno de uma ideia forjada de povo, fossem quais fossem as forças criativas mobilizadas para tal. Assim, uma prática popular passaria a ser o centro de convergência das representações do nacional, e um time como o Corinthians centralizaria a imagem do trabalhador. O fim da cena, portanto, é marcado pelo uníssono de que o Corinthians seria o "coração de São Paulo" seguido por Olho Vivo, que, em seu papel de narrador/Coringa, evidencia melancolicamente a origem de tanto engajamento com o time.

Quando registra como justificativa aos despejos em curso a construção do "Itaquerão", a peça nos apresenta uma fratura naquilo que foram outrora as expectativas políticas defendidas pela Nova Esquerda, e demonstra a estratégia espetacular usada pelo Partido dos Trabalhadores para separar sua base militante (formada por trabalhadores e ideólogos de esquerda) da política de conciliação de classes que foi efetivamente levada adiante em suas gestões. Ao estimular e financiar a construção do estádio do Corinthians, como se ali estivéssemos diante da representação simbólica do trabalhador, o PT consolidava uma política ambígua de hipervalorização fetichista da imagem do trabalhador, ao mesmo tempo em que se associava às forças do Capital no sentido da gestão da pobreza. Agia, assim, em oposição às práticas e demandas dos movimentos sociais organizados que estavam na sua base e na sua origem, acelerando e viabilizando o desmonte desse Estado por meio de uma imagem espetacularizada de uma gestão de esquerda ${ }^{29}$.

\footnotetext{
${ }^{29}$ Torna-se de primeira importância salientar que a peça, criada em 2011, realizava uma crítica à esquerda contra a gestão do Partido dos Trabalhadores no governo federal. O curso da história trouxe a esta pesquisa impasses que se tornaram evidentes graças à reação conservadora perpetrada pelo processo de impeachment da Presidenta Dilma Roussef e ao golpe de Estado em curso a partir de 2016. Tal processo, que debilitou ainda mais as organizações e movimentos sociais de esquerda, apenas torna mais patente a fragilidade das políticas realizadas pelo Partido dos Trabalhadores. Embora estas tenham alcançado melhorias substanciais na vida dos trabalhadores, não realizaram as reformas estruturais necessárias para assegurar seus direitos e os avanços alcançados. Nesse sentido, o ataque por parte do novo governo aos direitos trabalhistas e previdenciários, bem como a perseguição às organizações sociais, se faz notar como mais uma ruptura em nosso processo político e organizativo. É também importante relembrar que havia antes, no passado, e há agora, no presente, movimentos de base e organizados vinculados ao PT. O próprio movimento de teatro de grupos e a lei que instituiu o Fomento ao Teatro para a cidade de São Paulo foram fruto de gestões e de mobilizações fortemente ligadas ao partido, tendo importância central
} 
A construção do estádio do Corinthians em 2010, que fez parte das comemorações ao centenário do "time do povo", aparece na primeira versão do texto publicada e era central na primeira temporada da peça, em 2011. Na versão publicada em 2016, o fato se torna menos evidente, ainda que permaneçam as principais críticas ao processo de aliança de classes sustentado pelo PT. As transformações do cenário político nacional no período são inúmeras e até mesmo o contexto dos despejos e das lutas periféricas se alterou substancialmente. Todavia, os elementos que revelam o papel do Estado e sua centralidade para a administração dos conflitos que emergem no atual contexto periférico é imprescindível para analisarmos ambos os textos. Embora a versão de 2011 traga isso de maneira mais explícita, expondo as contradições no calor da hora, a versão de 2016 mantém a centralidade da crítica ao Estado para viabilizar a crítica ao mercado, esse duplo que reporta, estrategicamente, suas responsabilidades um ao outro.

A “Organização interrompida", portanto, que dá nome à cena, remete a tempos diversos da organização popular e que se sobrepõem na proposta da Brava Companhia. O Golpe de Estado de 1964 entra em cena por meio da tentativa de Olho Vivo e dos grupos culturais ligados à militância de reestabelecer os vínculos políticos entre as diversas instituições. A contemporaneidade, por sua vez, é interpretada como um golpe espetacular de sentido neoliberal, que se dá por meio da separação entre imagem e substância da política construída ao longo da década de 1970. É a imagem fetichizada do processo que, como sustenta Guy Debord (1997), em A sociedade do espetáculo, produz a identificação entre o sujeito e o espetáculo. Com isso, a política é transformada em imagem de si, ação esta que conjuga o próprio espetáculo, correspondendo, nos termos do mesmo autor, ao mercado.

Sendo assim, ainda que a "Era Lula" registre uma transformação substancial na realidade das classes mais baixas, foi sobretudo por meio do acesso ao consumo e de políticas de inclusão social que isso se deu. As condições do mundo do trabalho se adensaram e se transformaram na mesma medida, apontando para uma maior precarização e endividamento dos trabalhadores. O estímulo ao empreendedorismo levou, consequentemente, à desagregação das organizações políticas pautadas pela figura histórica do proletariado, e o descrédito político que veio com as denúncias de

para os avanços sociais notórios no período. A nova configuração do Estado, ainda mais agressiva e neoliberal do que a problematizada pela peça, não parece ser uma saída para o impasse, mas antes reforça, com uma nova ruptura no curso da política nacional, a fragilidade do Estado diante do mercado. 
corrupção corroborou para o maior enfraquecimento das organizações sindicais. Em sentido oposto, a aliança com os setores liberais da sociedade, implicados na importante tarefa de modernizar o Brasil conservando as forças regressivas presentes em uma regulamentação ambígua, abriu caminho para que a pobreza fosse gerida, ou reprimida, pelo Estado, colocando-se panos quentes no histórico conflito de classes.

Isso remonta, em última análise, às dificuldades de organização política e mobilização dos coletivos culturais e militantes, tema central em Corinthians, meu amor - segundo Brava Companhia. Os ventos que sopraram, desde o início dos anos 2000, a favor de uma produção cultural engajada com o campo social na cidade de São Paulo parecem agora ter tomado outros rumos diante das propostas de políticas públicas e programas de inclusão social. As mudanças ocorridas no período culminaram em uma divisão mais profunda das políticas de esquerda a partir de 2006, e o projeto de aliança de classes levado a cabo pelo PT para garantir a governabilidade demonstrou ostensivamente a sua fragilidade diante das forças mais conservadoras que vieram à tona depois de 2013.

Em 2010, como parte das ações de pesquisa financiadas pelo programa de Fomento ao Teatro para a cidade de São Paulo, a Brava Companhia convidou a Rede de Comunidades do Extremo Sul de São Paulo, um movimento de moradia da região, para um ciclo de debates chamado "Bravas Conversas", no qual se discutiria produção cultural e identidade de classes. A presença de um coletivo autogestionado para contribuir com a formação política da Brava reflete-se diretamente no conteúdo da obra e sugere esforços do grupo para a articulação de uma movimentação política autônoma, em contraponto às políticas de Estado, ainda que o encontro receba o aporte financeiro estatal. Nessas "Bravas Conversas", publicada no Caderno de Erros II da Brava Companhia (2011, p. 223-251), um integrante da Rede de Comunidades do Extremo Sul expõe sua experiência, situando o papel do Estado na configuração da identidade de classes: "O proletariado não se constitui como classe de uma maneira automática. Ele não pode se constituir por meio de estruturas fetichistas como o Estado". A sua constituição, como dá sequência o militante da Rede de Comunidades do Extremo Sul, está diretamente ligada ao ato de transformar essa oposição potencial entre burguesia e proletariado em luta e organização política, ou seja, apenas acontece por meio do engajamento direto com a produção dessa oposição. 
Na mesma Brava Conversa realizada com a Rede de Comunidades do Extremo Sul, algumas das implicações das políticas governistas e de suas relações com o processo cultural periférico são abordadas na expectativa de que o encontro cultural possa fazer as devidas reflexões sobre os processos organizativos de luta. Na conversa, podemos observar que, para alguns integrantes da Brava, a articulação das frentes de luta cultural, que despontara com a Lei do Fomento ao Teatro, perdeu seu momento histórico, tendo conduzido a produção cultural a uma realidade em que "a gente não consegue nem se organizar", deixando de convidar para a conversa, por exemplo, a D. Maria - mulher responsável pelo clube de mães da Vila Remo - ou, ainda, reconhecendo que parte dos coletivos que poderiam somar estão cada qual em suas sedes, realizando suas conversas e publicando seus materiais. Esse aspecto, muito embora consista em uma contribuição fundamental para a pesquisa e documentação dos processos, também evidencia a falta de interação entre o conhecimento produzido e o corpo social e político.

A fala da militante comunitária Mara na peça, portanto, já exigiria sua representação como ausência, mesmo sem a interrupção dos torcedores, posto que a dificuldade de organização política se estende também aos encontros com outras frentes de mobilização. Mesmo quando recorrem à participação junto a movimentos sociais mais consolidados, como o MST, parece haver um limite imposto pela nova lógica da cultura que inviabiliza o avanço da organização de esquerda, como aparece retratado de maneira breve na terceira cena do espetáculo, "Nova tentativa de organização". A cena mostra o momento em que Olho Vivo é novamente interrompido por um gol do time adversário ao tentar retomar o assunto trazido pela militante Mara. O personagem, então, reflete mais uma vez sobre as efetivas disputas no Campo do Capital: "a bola é pesada demais pra se agarrar sozinho. Mais dia ou menos dia o jogo vai ter que mudar. Enquanto isso, o campo fica aberto pras tentativas" (BRAVA COMPANHIA, 2011, p. 249). Ao deixar um boné do MST, ou qualquer outra referência a lutas populares atuais sobre o balcão do bar, Olho Vivo busca aludir à esperança diante de mais uma derrota da esquerda. A menção ao MST alude também a uma aprendizado histórico embutido em tal organização que não pode ser ignorado e que consiste na própria resistência dos trabalhadores no Brasil. 
As repetidas tentativas de organização interrompida que estruturam o "Primeiro Tempo" de Corinthians, meu amor: segundo Brava Companhia desenham o novo contexto social sobre o qual se assenta o trabalho do grupo. Ao indagar-se sobre o fato de que o produtor cultural de pequena escala pode estar se tornando agente de uma nova indústria cultural, reforçando, portanto, a ideologia burguesa ao acreditar no ideal de ascensão da "nova classe média", cujo sucesso dependeria de seus próprios esforços como "empreendedores de si mesmos", a Brava se embrenha em um problema relativo ao seu próprio lugar como produtora cultural periférica, assumindo um alto risco político. Nesse contexto em que artistas e movimentos sociais passaram a atuar dependentes e limitados, de certo modo, aos entraves de financiamentos estatais, pelos quais tanto se batalhou antes, o questionamento sobre o papel da cultura militante provocou o refluxo na luta direta conforme se passou a acessar fundos desenvolvimentistas e a se naturalizar a ideia de competição por editais e financiamentos.

Nesse sentido, a ideia de "sujeito periférico" torna-se ainda mais passível de crítica ao reconhecermos que esse novo produtor cultural está pronto tanto para se alinhar a um "nicho de mercado cultural periférico" quanto para apontar uma nova possibilidade de identidade de classes, pensada a partir da desagregação do mundo do trabalho. Contudo, a modernização das formas de gestão da pobreza parece ter aprofundando o problema, produzindo uma cultura para consumo interno à própria classe, ou seja, com pouca relevância no debate público. A cultura militante para consumo é, contraditoriamente, o resíduo indesejável de um processo de apropriação dos meios de produção; quando vista da perspectiva das lutas de esquerda, corresponderia a uma forma de obliterar a oposição entre burguesia e proletariado que viria a se acirrar na produção cultural, tornando-se um produto espetacular lançado no mercado de bens simbólicos. ${ }^{30}$

É em uma noção de aprendizagem, calcada no contexto da atual organização das forças produtivas e da apreensão de um momento de dissenso das lutas, que nos apoiamos para estabelecer os paralelos entre o trabalho de Brecht e as proposições da

30 Isto, porém, não significa que não existam frentes de trabalho cultural exteriores a tudo isto, e realizadas em outras bases, com outros agentes. Frentes cujo trabalho não é detectável dentro do âmbito dos grupos mobilizados para a captação de recursos de editais, ou até mesmo que fazem uso destes recursos com fins militantes. 
Brava Companhia. O reconhecimento de que o trabalho do grupo é pautado pela tradição do teatro épico ${ }^{31}$ subjaz na pesquisa estética do grupo e na tradição de uma perspectiva crítica que fundamenta a produção cultural dos grupos teatrais com engajamento político. Todavia, para nós, o problema ganha novos contornos dada a impossibilidade de tomar de assalto a instituição cultural burguesa e a indústria de massas e produzir, dentro delas mesmas, um conteúdo crítico, como seria o objetivo primeiro preconizado por Brecht para o seu teatro épico. As ideias sugeridas para suas peças didáticas, por outro lado, parecem contribuir para compreendermos o propósito político das formas encontradas pela Brava Companhia, na medida em que essas têm o público como coator e coautor desse processo de construção social.

O desenlace desse problema, dessa aparente fratura no processo de organização política que vinha tentando ser estruturado, vem com a chegada do televisor trazido pelo personagem do Palhaço. Aqui, anteciparemos a análise da cena que fecha o "Primeiro Tempo" no intuito de deixar explícito o paralelo temporal proposto pela Brava, já que todas as sequências implicam nessa temporalidade difusa produzida pela indústria cultural, estabelecendo paralelos históricos entre os processos culturais durante o regime ditatorial e os da contemporaneidade neoliberal. A centralidade da experiência televisiva como produtora do espaço comum - espaço público - remonta à ditadura na medida em que esta buscou forjar uma homogeneidade na relação espaço-tempo em todo solo nacional, produzindo a ideia de identidade nacional. Contudo, o presente representado pela peça Corinthians, meu amor: segundo Brava Companhia revela o que foi ocultado pela ação homogeneizante da cultura de massas, apontando para as divergências internas ao conceito de popular.

Com a chegada do televisor, roubado, diga-se de passagem, acompanhamos pela primeira vez todos os personagens implicados em solucionar um problema comum. Entre os personagens, há aqueles que são peritos em "gatos na eletricidade", que desenvolveram suas possibilidades entre a insurgência e a viração. Marcito, por sua vez, se destaca com a pompa de ter realizado a formação técnica em eletrônica pelo SENAI, ainda que seus conhecimentos não sejam suficientes para resolver o problema. Entre

\footnotetext{
31 Esta "tradição" à qual nos referimos aqui concerne a um diálogo estabelecido pela Brava Companhia com trabalhos como o do CPC e do Opinião, de Augusto Boal e Vianinha. Sobretudo mediado pela ação teórica e militante da autora Iná Camargo Costa junto ao movimento de teatro de grupo, tal tradição de teatro épico demarca um "chão comum" entre os diversos trabalhos vinculados ao movimento de teatro de grupo da cidade de São Paulo.
} 
explosões e quiproquós, os torcedores conseguem ligar o aparelho, que pega mal e sofre interferências fundamentais para a apreensão crítica do conteúdo propagado pelo televisor.

Embora a questão da indústria cultural permeie todo o espetáculo, esse é o primeiro momento na peça em que entramos em contato com procedimentos audiovisuais e, como procuramos apresentar, o recurso não aparece de maneira descontextualizada da própria narrativa. A escolha diz respeito a uma camada de intersecção entre realidade e ficção proposta pelo todo da obra, que se relaciona diretamente com a prática militante do grupo na medida em que a Brava Companhia busca incorporar ao acontecimento cultural que está sendo vivenciado aspectos pertinentes ao seu processo de trabalho. A crítica acerca dos meios de produção e reprodução técnica da cultura reivindicam, no corpo do espetáculo, uma metalinguagem sofisticada no que se refere à disputa ideológica no campo cultural.

Como afirma Benjamin (2012) no ensaio "O autor como produtor", todo uso da técnica veicula, implicitamente, seus modos de produção. Nesse sentido, a premissa do encontro cultural como parte da técnica teatral, aprofundada com uma orientação política crítica, é capaz de se opor diretamente à maneira planificada com que a indústria cultural produz imagens pretensamente populares. Associa-se a isso o esforço coletivo de criação "que pode ser muito importante para questionar e para desmistificar as formas dominantes de produção e circulação; de recepção da Cultura" (BRAVA COMPANHIA, 2011, p. 233) ${ }^{32}$.

A ação de todos os personagens para fazer com que o televisor venha a funcionar tem por base um repertório teatral tomado da comédia popular, do teatro de revista, do cabaré e do teatro épico, produzindo a contraimagem das técnicas da cultura de massas que, por fim, são o objeto central da crítica proposta pelo espetáculo. Quando o aparelho de televisão definitivamente funciona, a situação proposta pelo grupo faz com que ele não funcione adequadamente e, devido às interferências no sinal de transmissão, leva à cena a contradição que centraliza o debate cultural travado pela peça: a representação do popular forjada pela militância e seu contraponto na expectativa de consumo sustentada pela comunicação de massas.

\footnotetext{
${ }^{32}$ Fala de Guto, integrante da Rede de Comunidades do Extremo Sul de São Paulo durante o debate "Bravas Conversas".
} 
A produção dessa estética não parte da negação da técnica, mas da elaboração crítica de seus pressupostos classistas, que induzem a assimilação de suas contradições e sua naturalização, e não a denúncia e o estranhamento. A expressão da técnica audiovisual subjetividades; portanto, quando o aparato técnico não funciona, ele se revela, como é o caso do televisor ao longo dessa cena, tornando impossível seu desaparecimento e contribuindo para evidenciar a sua perspectiva ideológica.

Enquanto o personagem do Palhaço segura a antena para tentar sintonizar o aparelho, a primeira sequência de imagens apresenta os comuns patrocinadores do futebol em meio a cenas do jogo. Na sequência, o desejado jogo de futebol é sobreposto a diversos programas jornalísticos e tabloides que comentam os absurdos naturalizados pela indústria do entretenimento. Na dificuldade de sintonizar o canal, vemos que aquele material está sendo manipulado pela dramaturgia que, associada a elementos cômicos, nos mostra a alta periculosidade do personagem do Palhaço, representado pela televisão como um bandido procurado pela polícia num programa aos moldes do Cidade Alerta $^{33}$. A simpatia e o carisma do personagem e o seu ato heroico de conseguir um televisor para o grupo são contrapostos à representação midiática de pânico e violência social proclamada pela indústria cultural e à ilegalidade do roubo, perpetrado como gestus que comove o grupo a despeito das condições morais implicadas em tal ação. Como ambos os enunciados estão sobrepostos, a cena se coloca como uma pergunta, que nos indaga sobre a real condição daquele personagem.

Em seguida, a inauguração de uma casa no valor de R\$ 160 milhões, onde algum milionário viverá com sua mulher e duas crianças, e a cifra de R 8 milhões gastos na construção de mais um templo religioso são intercaladas a imagens de uma desocupação de moradia popular, mostrando cenas de violência policial contra manifestantes que tentam impedi-la. A essa interferência na programação do televisor se

33 "Cidade Alerta é um programa jornalístico policial brasileiro da RecordTV. Foi exibido, em sua primeira fase, de 1995 a 2005. Na segunda fase, foi ao ar de 20 de junho a 12 de setembro de 2011, inicialmente apresentado por José Luiz Datena, depois por William Travassos e por último Reinaldo Gottino. Voltou ao ar em sua terceira fase em 4 de junho de $2012 \mathrm{com}$ a apresentação de Marcelo Rezende para o estado de São Paulo e via satélite para todo o Brasil, além de versões locais exibidas nos outros 25 estados e no Distrito Federal.

É exibido de segunda a sexta, no final da tarde, em formato mesclado: policial e interativo, sendo também transmitido, ao vivo, pelo seu site oficial, no portal $R 7$. Além disso, conta com a interatividade das redes sociais. Em 21 de setembro de 2013, a fase atual do Cidade Alerta ganhou uma edição especial ao sábados, denominada Cidade Alerta Especial. O programa é acusado de desrespeitar inúmeros direitos humanos”. Disponível em: https://pt.wikipedia.org/wiki/Cidade_Alerta. Acesso em: 1 jul. 2017. 
segue o apagamento total do espaço de encontro, dando a ver um desfecho conclusivo para as sequenciais derrotas da organização popular diante dos processos midiáticos representados. Com a mudança da iluminação, passamos todos a acompanhar unicamente o vídeo projetado.

Um pequeno documentário, com imagens documentais inéditas registradas durante a ação da polícia no bairro, relata, então, a desocupação do bairro do Pinheirinho em São José dos Campos, em 2012, pela Polícia Militar do Estado de São Paulo. Esse fato, que, infelizmente, é comparável a inúmeros outros incêndios e desocupações de moradias populares, retoma a personagem da militante em chave invertida. O enfoque dado pelo vídeo apresenta a desocupação não do ponto de vista da resistência, mas, principalmente, do ponto de vista do massacre. O bairro do Pinheirinho e sua invasão por parte da polícia militar para uma reintegração de posse foi simbólico pela resistência popular que ocorreu na época; ainda assim, mulheres, crianças e idosos foram surpreendidos pelas bombas, em janeiro de 2012, fato este que obteve forte repercussão no período. Por outro lado, as vozes dos moradores aparecem no vídeo apresentando suas narrativas, repetindo fatos que são recorrentes nas experiências de reintegração de posse de terrenos nas periferias ou em atos de rua que reivindicam direitos sociais. A sequência estabelece relação direta com o discurso da personagem militante no início da peça no sentido de tornar evidente o fracasso da organização política que poderia fazer frente àquele massacre, ainda que tenha havido resistência. $O$ apagamento e o ocultamento do espaço cênico fazem com que a peça recorra à autenticidade produzida pelas imagens documentais jornalísticas para produzir uma identificação catártica com o conteúdo que aparece no televisor, no intuito de comover o público diante do desfecho trágico de mais uma luta popular. Ao fim da projeção, contudo, a luz retorna e o jogo do Corinthians finalmente é sintonizado no televisor. Com a vitória do time, atores e atrizes comemoram e festejam alienadamente, repetindo o Gestus proposto na cena inicial.

É impossível ignorar o estranhamento causado por essa sequência, já que a quebra da narrativa do espetáculo propõe um desfecho trágico para o problema da ausência de mobilização coletiva diante dos desmandos do Estado. As reiteradas tentativas de organização ao longo do "Primeiro Tempo", bem como a perspectiva política daquele encontro, que fora suprimida pela necessidade do coro de corintianos 
de assistir ao jogo, voltam à tona, recolocando as duas forças subjacentes ao todo - as forças da militância e da indústria cultural - em chave distanciada e crítica, o que nos obriga a analisar o processo de derrotas à luz dessa narrativa.

Apesar de usufruir de maneira restrita dos procedimentos audiovisuais, podemos intuir que seu uso e os avanços críticos que decorrem dele são centrais para o todo da obra. A técnica aqui é depositário de temas complexos e, conforme afirma Benjamin (2012), no já anteriormente citado ensaio, não surge sem consequências para o corpo social, já que é precisamente na relação com a técnica que podemos observar os avanços ou retrocessos da política. A linguagem per si é um campo de disputas e os procedimentos estéticos organizam esse embate. O avanço formal, aqui, reivindica uma aproximação não apenas com os temas, mas também com as formas de produção cultural crítica e com seu público. Nesse sentido, as premissas do TUOV são recuperadas e organizam o chão para esse debate. Ainda que a cena apresentada cause comoção e possamos nos identificar subjetivamente com aquela luta, o fato de não estarmos presentes ou diretamente engajados com a resistência e com a luta daqueles moradores nos protege das consequências do massacre, tornando possível, ainda que incômoda, a comemoração pela vitória do time.

A peça contribui como uma moldura para apreendermos as mediações da indústria cultural com relação à mobilização popular, e a cena revela o "efeito" produzido pelo televisor, fazendo um uso inverso daquele ao qual se destina. Ao separar o recurso técnico de seu conteúdo ideológico, a crítica recai não sobre um ou outro elemento, mas sobre a relação intrínseca entre ambos. Essa atitude reflete o cerne das reflexões de Brecht e de Benjamin, já que "para o autor como produtor o progresso técnico é um fundamento do seu progresso político" (BENJAMIN, 2012) e, ao identificarem-se as especificidades formais de cada recurso, amplia-se o poder dos autores sobre os meios de produção.

Todavia, não é apenas a relação próxima com o seu público que garante a qualidade política e crítica de uma obra de arte e, nesse sentido, a peça trava um árduo embate com a dimensão mercadológica da produção cultural contemporânea e seu insipiente mercado periférico. A cena fecha com Marcito aproveitando a deixa para divulgar o seu trabalho e vender sua imagem, demonstrando que não é apenas de televisão que sobrevive a indústria cultural - o problema da mercantilização da cultura e 
do apagamento das desigualdades sociais infligido por uma parte da produção cultural está mais próximos do que se presume. Se para os produtores da década de 1970 participar ou não da indústria cultural estava diretamente relacionado à adesão ou não a uma perspectiva mercadológica e a seus pressupostos, no neoliberalismo cada indivíduo se tornou uma empresa e o mercado de editais regula, em todos os campos da cultura, a disputa e a concorrência, seja qual for o conteúdo das obras. As principais ferramentas de gestão desse novo sistema são ideológicas e buscam envolver corpos e mentes na sua reprodução, fazendo com que, mais uma vez, a atitude militante e solidária corra o risco de perder o embate. Com isso, novamente o contraponto à impessoalidade da indústria cultural feito via encontro cultural é problematizado à luz de um Gestus contemporâneo. Neste, o lugar da produção crítica é ocupado por uma participação e um engajamento com um tipo de representação do popular que, embora reconheça o seu lugar de desigualdade social, não contribui para a superação do problema coletivo.

\section{1 Cena e contracena}

Com o fim do "Primeiro Tempo", chega também ao fim o tempo dos encontros culturais sem a mediação da cultura de massas. Nesse "Primeiro Tempo", a metáfora corintiana consegue incorporar o sentido popular, agregando a ele uma compreensão gestual contraditória e não moralizante que faz jus a uma perspectiva histórica, como proposto por César Vieira em sua dramaturgia. Essa escolha dá a ver elementos metafóricos que levariam os torcedores a solidarizarem-se uns com os outros, não apenas por meio da imagem do time, mas também por meio da sua narrativa de formação e das situações compartilhadas. Já o "Segundo Tempo" vem em sentido oposto, complicando essa identificação na sua problemática raiz espetacular.

O televisor e as formas de representação da população veiculadas pela mídia passam a suprimir os processos culturais autônomos, como metáfora do autoritarismo instaurado pelo mercado. A máxima popular "é a arte que copia a vida ou a vida que copia a arte?" passa a dar o tom dos demais fragmentos, e a representação passa a ter como modelo alguns programas televisivos populares e seus procedimentos formais. A partir daqui não é mais o progresso técnico que determina novas formas de relação, 
mas, com efeito, as formas veiculadas pela indústria cultural que passam a produzir novas subjetividades e novas situações vivenciadas pelos personagens. No "Segundo Tempo", vemos a ação da indústria cultural no sentido inverso, agindo para realçar ainda mais as divisões entre os populares a partir de suas relações com a superestrutura.

As cenas "Eu, você. Sem nós", "Peça interrompida 2", "Resistência Carnavalesca", "Santo Tino, o milagreiro" e "A Partida final" expõem, uma a uma, as instituições que sustentam o antagonismo entre sociedade e Estado. Se a contraimagem faz esforço para instaurar uma dialética na leitura dos Gestus, personagem por personagem, a sequência final vem no sentido de expor a dissolução da coletividade em face de algumas instituições fundamentais para a articulação de uma sociedade espetacularizada. Os quadros que se seguem são "contracenas" daquilo que vimos no "Primeiro Tempo", posto que partem da mesma matriz, propondo a representação daquilo que a mídia produz e fazendo uso de suas formas.

A primeira cena, "Eu, você. Sem nós", dá início ao segundo tempo e, já de partida, instaura uma nova relação com o espaço cênico. A luz é apagada e acompanhamos apenas um foco sobre dois atores. Essa mudança contrapõe-se à situação ficcional que vinha sendo compartilhada por atores e público e confronta diretamente a cena "Organização Interrompida 1", introduzindo um elemento subjetivo ao discurso por meio de uma situação dramática que poderia fazer parte da primeira cena. Todavia, ao instaurar um lirismo reflexivo, a cena conduz os personagens a uma resolução individual e subjetiva dos problemas, em sentido oposto ao que acompanhamos anteriormente. $\mathrm{Na}$ cena, dois personagens, designados por Um e Um, bebem juntos uma cerveja no balcão do bar e dialogam sobre as dificuldades vivenciadas por ambos. Dialeticamente, a cena expressa, para além da verve lírica, a ausência de individualidade de ambos, que parecem ser a mesma pessoa por partilharem problemas comuns:

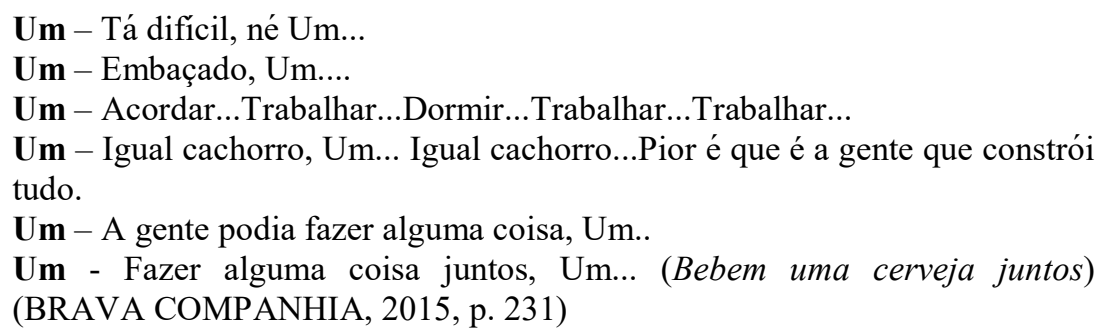


A expressão quase monológica dessa subjetividade é compartilhada e leva a dupla a desejar unir-se, não apenas entre si, mas com toda a população, fazendo algo transformador. A convergência de suas realidades parece ser suficiente para expressar o desejo de união, solucionando o problema apresentado pelo "Primeiro Tempo". Contudo, na sequência, quando decidem fazer alguma coisa e finalmente apontam para uma atitude, os dois personagens pegam seus bonés e os vestem, expondo times rivais que os fazem ver Um no Outro a inviabilidade da união. O fragmento sintetiza, alegoricamente, o primeiro movimento da peça, no qual vínhamos observando diferentes gestos sociais e reconhecendo neles os diferentes vetores que inviabilizam a identidade de classes e a organização.

A semelhança com a estrutura formal de uma novela em seu realismo barato, na qual, mediados por uma situação de consumo, os personagens conversam sobre os seus problemas essenciais e, por meio do diálogo, solucionam toda e qualquer dificuldade, é parodiada para demonstrar sua farsa ideológica. O Gestus que fecha a cena, a diferenciação entre os personagens no momento em que vestem o boné, demonstra a incongruência dessa solução dramática para um problema coletivo. O conflito se mostra interno à própria classe e não é um embate de desejos que fundamenta o impasse, mas um embate de imagens, ou seja, a aparência da diferença e a dimensão espetacular da identidade, franqueada pela indústria do entretenimento.

Ao estranhar o tipo de representação do real mais intensamente arraigado no imaginário popular, o modelo dramático realista tal como difundido dentro dos veículos de massa e exaustivamente explorado de maneira rebaixada pela indústria do entretenimento, também nós, do público, compreendemos a inviabilidade de combater o sistema a partir de parâmetros subjetivos e individuais. Isso porque, mesmo sendo a mesma pessoa, Um e Um não são capazes de se reconhecer e se identificar um com o outro, provando que a mediação especular realizada pela indústria do entretenimento não produz necessariamente uma atitude solidária, com consequências políticas.

Na sequencia, a cena "Peça interrompida 2" fará o mesmo movimento, trazendo a dimensão cultural periférica para o centro da alegoria. O Palhaço reivindica o protagonismo da cena, exigindo um número artístico naquele cabaré. A apresentação começa em tom de blague, assumindo, na medida em que a música avança, um tom agressivo e inflamado. A música Marcha Fúnebre Prossegue, do grupo de rap Facção 
Central, é a base para o movimento da cena e dialoga diretamente com a ampla vitalidade cultural presente nas periferias, e a partir da qual Tiarajú d'Andrea (2013) estrutura suas hipóteses acerca da formação de um "sujeito periférico":

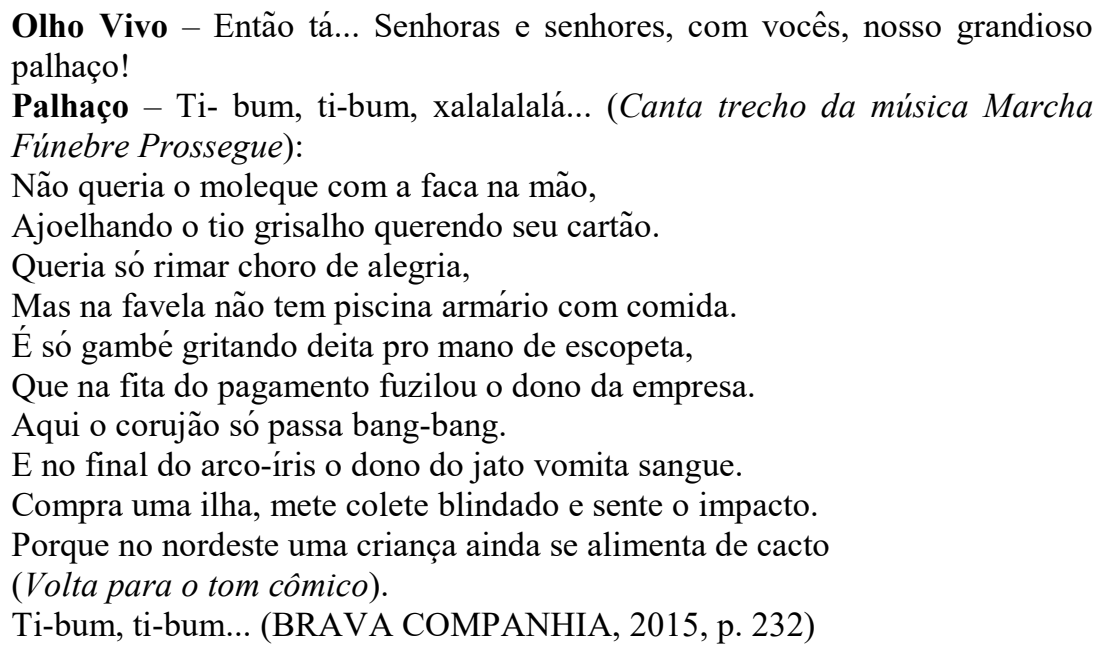

A política de massacre e repressão à população pobre e negra está no cerne da popularização do rap como forma artística capaz de representar as realidades sociais enfrentadas pelos moradores da periferia. A ameaça inscrita nas letras e a agressividade com que se dá a forma atingem o ouvido do bom apreciador da Música Popular Brasileira $^{34}$, seja pelo conteúdo, que já se impõe como uma denúncia ameaçadora, seja pela influência da música negra norte americana, que agride como uma metralhadora a harmonia do samba, como descreve Walter Garcia (2004). Contudo, a sua inscrição no repertório nacional marcou também o acesso direto da produção periférica ao mercado de bens simbólicos, e, à medida que a explosão do rap nos anos 1990 fez voltarem-se os olhos de toda a população para a miséria e a violência crescentes na sociedade, urgia a necessidade de mercantilização do gênero, bem como dos impasses visíveis nessa miserabilidade.

Roberto Schwarz sublinha (1999) o advento de Cidade de Deus (2002), de Paulo Lins, como uma obra literária de primeiro escalão que inaugura um novo tipo de

\footnotetext{
${ }^{34}$ Esse conceito é fruto do processo que se desenrola a partir da segunda metade dos anos de 1960. A relação intrínseca entre a MPB e a formação da indústria fonográfica no Brasil é determinante para a formulação do aparato ideológico nacionalista como defende Marcos Napolitano (2011). A hipótese levantada pelo autor, com a qual trabalhamos no curso desta pesquisa, é contraposta pelo RAP como forma de evidenciar que a unidade nacional permaneceu como um problema calcado nas questões raciais e sociais, conforme podemos observar na tese de Acauam Oliveira (2015).
} 
representação da problemática nacional, pautada não mais pela malandragem, mas pela ideia de marginalidade como parâmetro de apreensão de uma nova realidade social produzida pelo neoliberalismo. Na esteira do livro, diversos filmes também foram feitos no sentido de capturar esse novo imaginário, moldando-o de acordo com as novas exigências do mercado mundial, como é possível flagrar na própria versão cinematográfica do livro.

O que se passa na cena, contribuindo diretamente para a elaboração de tal problemática apresentada por Schwarz, é que, à medida que o personagem do Palhaço começa a cantar e se torna uma ameaça à ordem, o boteco é abruptamente invadido pela polícia. Por mais violenta que seja a interferência da polícia militar no boteco, vale frisar que, além dessa, outras atividades emergem do corpo social como formas de gestão da miséria; esta, intencionalmente, sofre tentativas de ser administrada para evitar o colapso. A polícia, na sequência, prova estar presente sobretudo para permitir a entrada da mídia no recinto, onde todos passam a estar "sob controle da televisão". (BRAVA COMAPANHIA, 2015, p. 233).

O problema se reflete na sequência da cena, instaurando uma crítica que não apenas se refere à influência midiática sobre o imaginário da população, como também problematiza a apropriação da miséria feita por diversas organizações sociais em suas relações com a indústria cultural e com o mercado de bens simbólicos. As intervenções de Unidades Policiais Pacificadoras e seu correspondente farsesco das UPPs culturais ${ }^{35}$ se equivalem, em certa medida, por dificultar qualquer tentativa emancipadora e crítica por parte das organizações populares.

Não à toa, a primeira interferência da ação da polícia, ainda ao final da cena "Peça interrompida 1", em forma de autuação devido a denúncias de perturbação da ordem. $\mathrm{O}$ argumento utilizado pela cena mostra a tentativa de manter-se dentro de regras calcadas na legalidade, como alvará de funcionamento e autorização da vigilância sanitária. A cena apenas revela sua farsa quando, recorrendo a siglas, o policial começa a exigir o acerto de contas com o FMI ou o KLB, banda pop que teve uma breve repercussão na indústria cultural jovem. O quadro é complexo e mobiliza

35 UPPs Culturais é um termo irônico utilizado para designar projetos culturais assistencialistas que passaram a se disseminar nas periferias das cidades. Tais projetos, que tem como base experimentos como os realizados em Medelín, na Colômbia, partem da premissa de que é possível pacificar uma zona onde há enormes desigualdades sociais e violência por meio da inclusão dos jovens em práticas culturais e artísticas. 
diversas frentes da gestão da pobreza. Salvo engano, a administração pública tendeu, nos últimos anos, a inviabilizar algumas iniciativas autônomas a partir de leis como a "Lei do Psiu", a "Lei de Proteção aos mananciais", ou, ainda, no caso da Brava Companhia, a tomada do espaço para a futura implementação de uma Unidade Básica de Saúde. Mesmo que as causas sejam calcadas na legalidade, o que se observa é o fechamento de um cerco à produção cultural autônoma - por vezes recorrendo-se à ação da polícia -, o que se opõe diretamente à criação e à implementação de espaços culturais geridos pelo Estado ou por ONGs.

Nesse sentido, quando atentamos à apropriação feita pela mídia da cultura popular ou periférica, o que buscamos efetivamente é apontar sua correlação direta com os pilares do Estado e do mercado, ponto este de inegável centralidade para as lutas populares. Com isso, o que Corinthians, meu amor - segundo Brava Companhia tenta assegurar é que o público compreenda os Gestus apresentados no "Primeiro Tempo" não como resposta individual à realidade apresentada, mas como intervenção direta do sistema político-econômico, propondo, por essa via, não a atualização de uma peça escrita nos anos de 1960, mas a compreensão de que as perguntas por ela levantadas se relacionam diretamente com o contexto de produção da obra.

\subsection{Ação direta da indústria cultural}

A realidade instaurada por essa cena difere substancialmente dos pressupostos apresentados pelo texto original, e aqui podemos analisar as principais diferenças entre as proposições de César Vieira e as da Brava Companhia. Em ambas as versões de Corinthians, meu amor temos a personagem Gabriela como figura central para compreendermos, de modo histórico, a relação crítica entre a indústria cultural e o povo. Na primeira versão, a insipiente indústria cultural não aparece ainda como objeto de críticas tão diretas, mantendo-se viva a possibilidade de vislumbrarmos potência progressista em suas organizações. Já no Corinthians da Brava, a situação se inverte diante de um processo de mercantilização total da cultura.

Gabriela, no Corinthians da Brava Companhia é, como já apresentamos, uma estudante de jornalismo, idealista, apaixonada pela vida popular e periférica, que está 
realizando seu mestrado no boteco do Olho Vivo e, por isso, passa a frequentar o local. Para além do Gestus que representa, a personagem ocupa também, alegoricamente, o papel da mídia em sua relação direta com a população da cidade. Dessa forma, no "Segundo Tempo" da peça descobrimos que Gabriela faz estágio em uma emissora de televisão, a TV Concorde, e, aproveitando seus contatos, a estagiária faz uma proposta "irrecusável" a Olho Vivo. A essa altura, ela passa a agir não apenas no sentido de apreender ou apropriar-se da vida periférica, mas também no sentido de "ajudar", revelando em seu Gestus inicial a contradição que lhe é inerente:

Gabriela - Posso entrar agora? Gente, vocês nem imaginam! Eu consegui uma coisa super legal! É que tô fazendo meu estágio de jornalismo lá na TV Concorde, e o meu diretor precisava de uma locação pra gravar um concurso de dança, um lugar assim... Tipo na periferia. Com gente assim... Para o público Tipo vocês. Para Olho Vivo. Aí eu mostrei umas imagens que eu tinha e o meu diretor super adorou. Aí eu pensei: por que não fazer uma parceria TV Concorde e Bar do Olho Vivo... Aí o senhor vai poder divulgar o seu trabalho, vai ser muito legal. Enforca Olho Vivo.

Olho Vivo - Mas... Você fez parceria sem falar comigo?

Gabriela - Ah... É que eu fiquei empolgada... E o Seu Moacir falou que o senhor adoraria. (Moacir aponta arma para Olho Vivo).

Olho Vivo - É... Adoro, adoro sim. Mas, é só parceria? Será que não rola nenhum incentivo?...

Gabriela - Incentivo?.(BRAVA COMPANHIA, 2015, p. 234).

A proposta de parceria "unilateral" feita por Gabriela no fragmento que apresentamos acima traz à tona um elemento central para este estudo. Como já discutimos, os meios de produção cultural e a maneira como a Brava Companhia se apropria criticamente de seus termos implica em compreendermos as novas formas adotadas pela indústria cultural contemporânea na gestão de conflitos sociais. Tanto a imposição do aparelho do Estado, representado pelo personagem Moacir, quanto a audácia empreendedora da personagem Gabriela que, na maior das boas intenções, decide divulgar o pequeno boteco são representativas da atual configuração das forças produtivas no campo da cultura. Premiado pela possibilidade do "incentivo", Olho Vivo questiona, no pequeno fragmento, aspectos intrínsecos ao aparelho estatal que agem sobre a periferia na forma de projetos culturais de pacificação e de policiamento.

Essa configuração da indústria cultural, uma novidade contemporânea, aciona as massas de maneira uniforme por meio da interatividade, envolvendo os espectadores em um espaço público mediado por sua produção ideológica e por suas formas de 
representação. Mais do que isso, também proporciona modos de gestão da pobreza que têm por base o vislumbre da vitória individual por meio da capitalização das imagens da miséria superada. As narrativas de superação, veiculadas diariamente pelas representações midiáticas, assumiram um novo formato, no qual a possibilidade de inclusão de alguns "escolhidos" pelo sistema pressupõe um amplo grupos de excluídos e marginalizados, que serão violentamente reprimidos.

A figura de Marcito, em todo o "Primeiro Tempo", age no sentido de nos mostrar esse Gestus implicado no seu sucesso individual, que eclode, então, na sequência da cena, com a possibilidade de sucesso diante das câmeras. Devido à participação de Gabriela, o boteco é invadido pela indústria cultural e, a partir daí, tanto a representação daquela realidade passa a ser objeto de manipulação quanto a própria sobrevivência daquele espaço passa a ser suscetível à intervenção do Estado e do mercado por meio de incentivos e parcerias institucionais que arregimentariam seus produtores para uma incorporação ideológica de suas práticas. A indústria cultural, tal qual demonstra a cena, não somente representa os populares de maneira equivocada, mas também produz neles a sensação de participação e inclusão no sistema de representação.

Tomada de maneira radical, essa crítica se estenderia para diversas organizações culturais que, de maneira contraditória, reproduzem as lógicas produtivas da cultura burguesa junto à população pobre. Assim, retomando a reflexão proposta por Piscator (1968) acerca da representação e identificação das classes populares com a ideologia burguesa, a despeito dos esforços de tantos artistas em construir uma cena proletária:

\footnotetext{
vale a pena notar quanto tempo leva o proletariado organizado para entrar em relação positiva com o teatro. Vale-se de todas as possibilidades de expressão da sociedade burguesa [...] e depois, o proletariado dos anos 1970 e 1980 segue ainda inteiramente em matéria de arte, o caminho das opiniões burguesas (PISCATOR, 1968).
}

A cena pontua, portanto, as formas pelas quais na produção cultural contemporânea, os modos de produção de imagens populares são sustentados por esse mesmo aparelho estatal burguês, incorrendo numa contradição estrutural que inviabiliza sua superação, na medida que repõe a ideologia que se espera combater. 
Antes de seguirmos nas análises, faremos um novo recuo histórico em direção ao teatro militante dos anos de 1970. À época, o governo militar, aliançado com a burguesia liberal e respaldado pela expectativa de sobrevivência de uma parcela dos produtores culturais, iniciou o processo de subsídio à produção cultural. Nesse momento, uma parte da produção cultural à esquerda passou a receber financiamento para suas produções, sendo que diversos orgãos culturais e leis de incentivo foram criados no intuito de organizar essa distribuição. Para os grupos de teatro, esse envolvimento com o financiamento público-privado, que passava a se consolidar como forma de ajuste entre a sociedade civil e o regime, foi visto com desconfiança, como descreve Silvana Garcia (1990) pois implicava em recuo político diante de um estado autoritário. Nesse sentido, a postura do Teatro União e Olho Vivo de permanecer em situação amadora, resistindo ao enlaçamento das novas formas de cooptação cultural, demarcava uma consciência crítica atenta à associação intrínseca entre Estado e mercado, ainda que isso não fosse evidente no discurso das peças.

O otimismo gerado pela formação do Partido dos Trabalhadores, que arregimentava o pensamento progressista da sociedade civil em seus quadros, tornou possível o vislumbre de um Estado que se responsabilizaria pelos direitos da população dentro de um regime democrático. Assim, com a participação da sociedade civil e norteadas pela possibilidade de efetivar um real "acesso aos meios de produção" por parte das classes trabalhadoras, as políticas culturais avançaram de forma significativa. Se inscrevem nesse contexto a criação da Cooperativa Paulista de Teatro, em 1979 e, principalmente, a vitória conquistada pela classe artística na implementação da Lei de Fomento ao Teatro, em 2002. Esta tornou-se parâmetro para novas políticas públicas no setor, satisfazendo artistas e a intelectualidade, que não tardaram em reconhecer a vitória que pautava, de fato, avanços organizativos nos modos de produção cultural. Reconhecidamente, também os avanços estéticos e a organização política frutificavam em consonância com os ideais progressistas, que tinham apoio numa conjuntura de fortalecimento do PT como representante da classe trabalhadora.

Ao término do primeiro mandato do presidente Lula, o mesmo grupo que the dera suporte para a eleição presidencial já apontava, criteriosamente, o desvio no programa de governo que, pelo intermédio de alianças com os setores liberais, fragilizara a organização popular. Não à toa, a partir de 2006 instaura-se uma crise, seja 
nos movimentos sociais mais sólidos, seja no teatro de grupo da cidade de São Paulo, com um refluxo organizativo. A coexistência do modelo liberal de incentivo à cultura, por meio de renúncia fiscal, e dos financiamentos públicos diretos, por meio das políticas públicas, pendeu a balança para o mercado, que passou a ter na produção cultural, inicialmente sustentada pelo financiamento público, um novo nicho de investimentos.

Por conseguinte, a pequena "parceria" entre a TV Concorde e o boteco do Olho Vivo demonstra que, para o sistema cultural, o local é um "empreendimento cultural" que carece de divulgação, valendo a pena para o pequeno produtor per si, mesmo sem o incentivo financeiro real. Nesse caso, é importante sublinhar o tom irônico com que Olho Vivo interpela Gabriela, já que para o personagem também o "incentivo" é duvidoso, dada a perspectiva militante com que conduz o seu trabalho. Para Gabriela, por sua vez, ser a ponte entre o proprietário do boteco e o produtor da TV Concorde agrega valor à sua força de trabalho, e possivelmente acarretaria uma promoção dentro da emissora. Sendo assim, acompanhados pela "idealista amiga dos pobres" e pela "força do Estado" e dessa nova forma de indústria cultural, a TV Concorde invade o boteco para gravar um programa popular, inviabilizando a organização política almejada por Olho Vivo.

\section{Cena 10 - Resistência Carnavalesca}

Diretor (entrando no bar) - Pode deixar, Gabi. Eu assumo daqui.

Gabriela - O meu diretor!

Diretor - Pessoal, ao trabalho! Nossa! Olha esse lugar... Tipo perfeito. Ele é rústico, mas ao mesmo tempo tem um certo ar de sofisticação... Olha essa gente.

Atores e atrizes distribuem adereços carnavalescos ao público

Gabriela - Esse aqui é Seu Olho Vivo...

Diretor - Senhor Olho Vivo, muito prazer! Grande figura da comunidade...Para Gabriela Gabi, põe um loiro lá.

Olho Vivo - Ei! Eu... (Moacir barra Olho Vivo e o orienta a sentar-se em um canto).

Diretor - Gabi, quem da comunidade vai falar?

Gabriela - É o Marcito. Chamando. Marcito!

Diretor - Nossa... Olha a cara dessas pessoas... Que fisionomia peculiar...

Moacir - Se precisar de mais pobres eu posso pegar mais um monte lá fora.

Diretor-Perfeito!

Marcito - Tentando ler em um papelzinho. Eu queria falar que (lendo) é muito bom ver o povo dançando. Enquanto houver quem dance, haverá quem escolhe a música (BRAVA COMPANHIA, 2015, p.235). 
A característica pitoresca do ambiente, somada a uma dose exata de "fisionomias peculiares", traz a autenticidade necessária para a cena midiática. O diretor da rede de televisão para a qual trabalha a personagem Gabriela chega e, com pequenas modificações na organização do espaço, transforma-o em uma locação perfeita para um concurso de resistência carnavalesca em que os competidores são alegorias do popular. A substituição de Olho Vivo na condução do programa, bem como a procura por um representante da comunidade, quase loiro, que possa ter voz dentro do evento, demonstram que a manipulação da representação se transferiu para o real, onde será filmada, ao vivo, a final do grande concurso de resistência à cidade de São Paulo.

O personagem Marcito, representante da comunidade, adere de modo acrítico ao papel que lhe é imposto graças ao desejo de fazer parte da cena midiática como um aspirante à fama. Aproveita, dessa forma, para fazer autopromoção, repetindo de maneira alienada o discurso que lhe foi entregue pela produção do programa. Já Moacir é quem garante a segurança dos diretores do programa e segue durante toda a cena as costumeiras "revistas policiais" em todos os presentes no bar. As relações são representadas não somente para problematizar a interferência do grupo de produtores da TV Concorde no local, mas, principalmente, para elucidar que a relação positiva da população com a mídia também faz parte do problema. O poder da mídia é representado como um "mecanismo de tomada de decisões que permitem ao modo de produção capitalista, transubstanciado em espetáculo, a sua reprodução automática" (BUCCI; KEHL, 2004, p. 20) dada a implicação subjetiva que incorpora o espectador ao processo por meio da expectativa de inserção. A correlação imediata entre esse desejo de inserção, expresso na figura de Marcito, e a marginalidade, evidenciada pela ação da polícia sobre todos os que não se inserem no Espetáculo, sustenta o poder midiático. Não à toa, aos vencedores dos reality shows, os louros que os glorificam, e todos os outros o Cidade Alerta encaminhará para o cárcere.

A passagem antecede a ação do vídeo - que apresentará uma espécie de paródia de um reality show promovido pela TV Concorde -, e prepara o público para uma cena televisiva em que o público seria o "auditório" da final do programa. Somos, com isso, poupados de nos ver dentro daquele pequeno televisor, mas, por outro lado, vemos toda a construção de uma farsa da qual participaríamos ativamente se estivéssemos envolvidos efetivamente com a sua realização. O movimento da cena busca revelar o 
outro lado das imagens produzidas, visando reivindicar o selo de autenticidade do real que é, por sua vez, a representação dessa realidade, desvelando ao público a manipulação da sua própria imagem e sua espetacularização.

Dados os avanços técnicos e a facilidade do acesso às câmeras filmadoras, o uso de imagens "pré-fabricadas" e de elementos do real em cena se tornaram mais comuns e passaram a dar a tônica da estética contemporânea, seja pelo alto grau de performatividade, seja pela pretensa autenticidade na representação do real. Silvia Vianna, no livro Rituais de sofrimento (2013), nos interpela, nesse sentido, com uma pergunta central para apreendermos a relação entre a Sociedade do Espetáculo e o mundo do trabalho na era neoliberal, que seria forjada por meio dos reality shows. A autora entende que estes atingiram o máximo de sua representatividade no imaginário do espectador ao instaurarem um espaço relacional análogo ao do mercado de trabalho, composto emblematicamente por participação e eliminação dos competidores via participação dos telespectadores, seguido do anúncio de uma próxima temporada de competidores aos quais o público poderá se unir para realizar-se enquanto sujeito do espetáculo.

Para Maria Rita Kehl, os diversos programas de reality shows seriam "a forma mais eficiente de ilusão que a cultura de massas já produziu", posto que "vendem aos espectadores o espelho fiel da sua vida amesquinhada sob a égide severa das 'leis de mercado"" (BUCCI; KEHL, 2004, p. 171). Tendo isso em vista, ainda que o programa de televisão que acompanhamos não seja um reality show e se assemelhe mais a um show de calouros, as considerações tecidas por Silvia Viana para compreender as relações entre esse tipo de programa e o mundo do trabalho são centrais para a análise da cena. O programa televisivo que acompanhamos, Resistência Carnavalesca, passa no televisor de maneira integrada à ficção, com os últimos momentos de uma competição em que vemos pessoas fantasiadas como em um bloco de carnaval dançando e se estrepando, caindo pelo caminho em diferentes pontos da cidade de São Paulo por não mais suportar o desafio de resistir a ela.

O vídeo, filmado pela Brava Companhia especialmente para compor o espetáculo, foi gravado assumindo o caráter de intervenção artística em locais emblemáticos da cidade. Os atores carregam cartazes com os dizeres "E o povo dança!" que, se lidos fora do contexto da peça, agregam à ação um componente de denúncia à 
população da cidade sobre os maus tratos implicados nas relações entre população e as instituições e locais por onde passa a pequena intervenção, como a prefeitura, o transporte público, etc. A ação, que contou com cerca de 40 artistas de diferentes grupos de teatro na sua realização, carrega traços de uma estética contemporânea que busca mesclar real e ficção como forma política, ressignificando o espaço da cidade à luz de uma perspectiva crítica que denuncia a opressão. Faz uso, assim, da ficção, de símbolos e dizeres críticos que são friccionados, por intermédio da performance, com o campo do real. Com isso, a estrutura de bloco carnavalesco, associada à máxima "E o povo dança!", configura para o transeunte da cidade uma cena crítica, análoga a um ato de rua estetizado, que questiona a função daquelas instituições, ainda que sem bandeiras concretas.

Nesse sentido, a sobreposição entre real e ficção dentro dessa cena nos possibilita uma análise crítica que se estende a todo o movimento cultural da cidade, já que é também a parceria entre os diversos grupos e artistas que viabiliza a intervenção estético-política filmada de ser produzida e incorporada pela cena. A tese defendida por Silvia Viana (2013) expõe de que forma esse procedimento de espetacularização do real - corrente na indústria cultural e, sobretudo, nos reality shows - aponta para um processo de naturalização das injustiças sociais inerentes à precarização do trabalho contemporâneo. Na mesma medida, esse procedimento estimularia tais injustiças ao alimentar a ideia de vitória e superação individual, tornando-se, portanto, alegoria da concorrência entre os trabalhadores.

A problematização trazida à tona por meio dessa cena pode ser lida também como metáfora da concorrência entre os próprios artistas e coletivos culturais pela sobrevivência no mundo dos editais. Relaciona-se, igualmente, à dificuldade presente em uma disputa que implica tanto o campo da representação do popular, ressaltada pela vitória de algumas formas de representação em detrimento de tantas possibilidades que tombam no caminho por não resistirem à competição, quanto a própria subsistência dos grupos e artistas.

Nesse sentido, embora não se trate de um reality show, a cena nos possibilita aventar como a dimensão do espetáculo é trabalhada pela indústria cultural, que incorpora ou permite o sucesso apenas das formas do popular que, em alguma medida, contribuem para a sua reprodução ao incentivarem a substituição de seus conteúdos 
combativos por outros conteúdos mais palatáveis na indústria do entretenimento. Em certo ponto, as estruturas fetichistas são preservadas em detrimento das práticas materiais e conteúdos implicados na resistência cultural. Essa manipulação das formas de luta social é pautada pela mitificação de dispositivos de confronto, que passam a ser apropriados pelo sistema e transmutados em dispositivos de controle social. Logo, a manutenção da dialética aparece como a única possibilidade de se compreender o problema em questão evitando-se o risco de sustentar qualquer forma social como inequivocamente combativa.

Até mesmo a máxima popular "o povo dança”, usada cotidianamente para dizer que o povo se prejudica ou apanha, pode ser transformada em slogan do programa da TV Concorde e ter o seu significado facilmente invertido, positivando as mazelas que acompanhamos no vídeo e veiculando tais imagens a partir de um segundo sentido. A narração do diretor do programa torna vitorioso o indivíduo que resistir ao massacre, ao invés de ressaltar a ação coletiva de denúncia da manifestação cultural:

\footnotetext{
Apresentador - E o povo dança! Em frente à Prefeitura! Dentro do ônibus! Um exemplo da força e da pujança do povo brasileiro. Um desmentido àqueles que nos chamam de subdesenvolvidos! Não é em todo lugar que se dança tanto, diariamente... É isso mesmo, o povo dança na cultura, na igreja... Aqui só os fortes sobrevivem, só os fortes prevalecem! Os fracos caem pelos caminhos. E o povo dança! TV Concorde: uma vez concorde, concorde sempre. Um oferecimento de Água da Felicidade - a água ardente no povo brasileiro (BRAVA COMPANHIA, 2015, p. 236).
}

A naturalização de diversas máximas populares, como "só os fortes sobrevivem" e "um desmentido àqueles que nos chamam de subdesenvolvidos", na voz do apresentador e como slogan do concurso de resistência, acaba por denunciar a perspectiva ideológica adotada pela indústria do entretenimento, tornando estranhos e questionáveis os concursos de mesmo tom, comuns na televisão nacional. Ao apresentar os "antecedentes da ação", ou seja, aquilo que não apareceria na cena televisionada, a peça torna questionável a sequência, conduzindo-nos a uma relação diversa com o material, já que somos obrigados a reconhecer que alguns dos presentes no público sequer fariam parte da disputa e já estariam eliminados na primeira seleção para a participação do programa, como não nos deixa esquecer o policial Moacir durante toda a cena. 
Assim, a inversão programática dos significados e ações populares, quando mediada pelo poder televisivo sustentado pela elite, revela-se tanto na forma como a indústria cultural faz uso de suas imagens quanto na linguagem. Esta, a exemplo da máxima popular e lamuriosa "o povo dança", pode, por conseguinte, ser revertida para sua literalidade a fim de que o apresentador possa utilizar-se dela num chavão positivo e estimulante, convocando a "força", a "pujança" e a "alegria" do povo brasileiro para, a partir daí, estimular a sua opressão. A operação exibe o poder da mídia, que se apropria da criatividade do povo para cristalizar uma imagem que sirva aos seus interesses e consiga se reproduzir incessantemente.

No desenrolar da cena, os participantes chegam ao boteco do Olho Vivo seguidos por um capataz. São anunciados os finalistas e vemos a diversidade do povo brasileiro. Jesus, representando ele mesmo; uma baiana, representando a migração; uma índia, representando Parelheiros, e um corintiano (Atílio), representado o time do povo, são os finalistas nessa empreitada. Por fim, em um "inédito" e "glorioso" empate, a índia e o representante do time branco e preto vencem o concurso, tal e qual nos dão a ver os três pilares de nosso "mito de formação nacional", já que o time alvi-negro representa a população negra e a população branca.

A vitória dos três representantes do povo brasileiro no concurso da TV Concorde e a junção do branco e do negro em uma só representatividade retomam a canção do prólogo "O canto das três raças", com a qual a peça indicou a relação entre indústria cultural, jugo do trabalho e povo brasileiro. Ainda que na aparência seus temas e formas tenham sido incorporados pela indústria do entretenimento como modo de fortalecer uma identidade nacional que pudesse organizar um povo, na prática, as separações entre os três pilares culturais da nação seguem vigentes e se evidenciam na relação direta com as forças produtivas. Cabe ainda ressaltar que a década de 1970 marca também o crescimento das lutas identitárias, seja do povo negro e quilombola, seja do povo indígena, e que ambas foram violentamente suprimidas pela ação da ditadura. Embora essa perspectiva não apareça nas formulações da esquerda durante a década de 1970, a incorporação acelerada deste instrumental de análise a partir das teorias que se tornaram hegemônicas nos Estados Unidos na mesma época, levanta novos problemas no debate contemporâneo. 
Também nesse ponto o papel da televisão e do Estado foi decisivo ao formular um sentido único no imaginário nacional pautado pela diversidade abstrata. Subtraindo das representações as diferenças regionais e sociais, tais representações impediram, portanto, que se organizasse um discurso ideológico que fizesse frente ao processo de modernização conservadora. Com isso, o que é ressaltado na voz "do homem que é preto, do homem que é branco" (BRAVA COMPANHIA, 2015, p. 201) ${ }^{36}$ opondo-se à canção que abre o espetáculo, que finda a disputa vitorioso na competição, é a incorporação de um discurso individualista e burguês por parte desse povo que se integrou à sociabilidade neoliberal estimulada pela mídia. Esse discurso incorpora a competitividade do mundo do trabalho e a eliminação de alguns populares em detrimento de outros, legitimando-se na sua narrativa e perspectiva unilateral. Essa ideia ganha força na voz de Atílio, na qual a possibilidade de vencer esse concurso de sobrevivência e resistência se mostra como viável, ainda que de maneira patética. Depois de comemorar com o discurso "Se eu cheguei até aqui, vocês podem chegar lá! Lá Onde?” (BRAVA COMPANHIA, 2015, p.237), o personagem tem a sua camisa do Corinthians retirada pelos outros torcedores. Atílio fica perecendo sozinho no chão, sem nenhuma identidade, abandonado, num fim de carnaval triste.

Dessa forma, a mediação pela imagem dos elementos do real nos obriga a tomar seu contexto de produção e reprodução como indissociáveis para que nos atentemos ao processo de montagem como vetor de apagamento de sua realidade. Para Roberto Schwarz (1999), o legado de Brecht e sua atualidade residem exatamente no esforço de expor tais contradições de modo que possamos compreender o movimento do Capital em curso. Não se trata, para o autor, de recursos ou procedimentos técnicos, mas de uma ação da obra com relação a seu momento histórico. Nesse sentido, o uso dos vídeos no Corinthians da Brava Companhia travam um embate com essa nova configuração da representação do popular, mostrando a engrenagem que compõe a transmutação da imagem da pobreza em espetáculo midiático.

Para compreendermos como esse aspecto aparece na cena, é imprescindível tomarmos o contexto da reprodutibilidade de materiais audiovisuais como instância a

\footnotetext{
36 "No meio do povo a Brava Agita a Bandeira/ Bandeira que é preta, bandeira que é branca/ do Homem que é preto, do homem que é branco. A bola correndo seu time a ganhar/ seu time a ganhar e o povo a sonhar/ sonhar com o povo, o povo vivendo/ sem ninguém pra pisar/ podendo cantar sem ninguém pra pisar/ querendo amar, querendo amar" (BRAVA COMPANHIA, 2015, p. 201).
} 
ser considerada. A situação ficcional, associada às imagens filmadas e ao discurso do apresentador, fricciona os conteúdos e formas diversas. $\mathrm{O}$ acontecimento que gera $\mathrm{o}$ vídeo carrega, por si só, um grupo de informações que intervém na realidade da cidade e efetiva-se como voz e discurso na própria ação, dialogando em termos modelares com as manifestações coletivas e atos de rua, alimentando-se de sua performatividade e palavras de ordem. Por outro lado, dentro da dramaturgia do Corinthians, meu amor da Brava, a mesma ação filmada e reproduzida passa a dizer o contrário, contribuindo para explicitar não apenas a manipulação midiática, da qual nenhuma ação política consegue se esquivar, como também contradições inerentes ao sistema produtivo, já que do confronto entre a ação político-estética do grupo e sua apropriação pela indústria cultural um novo problema se articula diante de nossos olhos. A tensão, portanto, entre formas épicas, dramáticas e performativas corresponde, de maneira oportuna, à forma encontrada pela companhia para agir sobre a realidade material da cultura e representar as forças em luta em uma sociedade de classes.

\section{3 A batalha final - um por todos ou todos por um?}

A dificuldade de representação da luta de classes sem incorrer em formulações que simplifiquem seus os impasses está entre os problemas enfrentados pela Brava Companhia. A manipulação dos sentidos de "popular" e de "trabalhador" complica o reconhecimento de populares e trabalhadores como classe, tornando ainda mais complexa a possibilidade de representá-los. Ainda que o debate proposto se circunscreva a relações sociais observadas a partir de um ponto de vista periférico, a violência desse sistema, advinda da ausência de direitos sociais em um estado neoliberal, amplia-se para todas as dimensões da produção. Enunciados dualistas, que buscam soluções para essa questão na identificação de opositores que personificam o problema, raras vezes conduzem a elaborações que contribuam para sua superação. Esse é o problema implicado, seja no dualismo entre centro/periferia, seja na formulação clássica do patrão/trabalhador, quando se busca tais paradigmas como forma de representação do processo social contemporâneo. Em face disso, o ponto de vista 
adotado pela Brava Companhia é marcado pela sobreposição de ambas as formulações, alcançando o problema de maneira diversa e apontando os seus limites.

Ao explicitar a ausência de antagonistas, a peça rompe com o pressuposto dramático de que haveria também um protagonista encarregado do movimento da fábula e do curso da história. Como já evidenciamos, o papel do Coringa Olho Vivo na estrutura épica de Corinthians, meu amor - segundo Brava Companhia é buscar se distanciar de qualquer atividade protagônica que pudesse erigi-lo a um posto heroico diante do processo apresentado. Todavia, na medida em que a televisão ganha espaço como forma de representação, a peça se depara com a necessidade de colocar o problema em outra chave, apresentando as consequências desse tipo de representação personalista pressuposto nas imagens espetaculares. Tendo isso em vista, as duas últimas cenas destroem o espaço do boteco de Olho Vivo, destituindo o seu ponto de vista narrativo para, na sequência final, apresentar outras formas de narrar esse processo.

A nova disposição espacial coloca o público em uma posição de espectador passivo, diante do movimento da cena, deixando evidente que o ambiente onde estamos não é mais o mesmo espaço relacional em que participávamos da construção da peça, mas que se tornou uma plateia. Tal passividade é criticamente examinada e questionada, e tal mudança de perspectiva da peça sugere ao público a transformação dos movimentos sociais entre o processo de luta pela abertura democrática e a institucionalização da democracia brasileira. Nesse caminho, as duas cenas finais são um culto religioso a "Santo Tino", que fez milagres para salvar o Corinthians, seguida pela "Batalha final", em que nenhum milagre fará o povo vencer o jogo.

Recorrendo pela terceira vez à paródia religiosa, "Santo Tino" retoma o debate do populismo, presente no texto original, deslocando-o do seu contexto político. Embora a associação seja valiosa para se compreender os efeitos e conteúdos dessa prática, a opção nos parece problemática na medida em que se relaciona objetivamente com o processo político nacional, buscando esconder a metáfora proposta a tal ponto que ela corre o risco de desaparecer.

A função mitificante sobre a qual se assenta a Sociedade do Espetáculo enquanto versão atualizada da indústria cultural é recorrer à formação de ídolos que sustentam uma unidade de reconhecimento comum. Numa espécie de teologia que 
separa o "ser" da "coisa" pelo intermédio do fetiche - por sua vez, "um termo religioso para designar uma idolatria falsa" -, a construção dos mitos se daria como uma paródia (no sentido de Agamben) do mundo espiritual. Como coloca Žižek, para Marx, a questão é que "o universo da mercadoria proporciona o suplemento fetichista necessário à espiritualidade 'oficial'” (BUCCI; KEHL, 2004, p. 79), o que, para Maria Rita Kehl, é sustentado pela ética cristã, produzindo a espiritualização das mercadorias e incorrendo no apagamento das relações materiais de produção. Essa relação esconde o corpo do trabalho morto e do processo de fantasmagoria, elevando o mito a uma dimensão totalizante à medida que apaga o mundo material.

Nesse sentido, a representação do goleiro Tino, um homem capaz de dar a vida pelo Corinthians, cujo maior feito foi impedir um gol do time adversário, levando o time à vitoria e os torcedores à total realização, pode ser transformada em matéria-prima para a constituição de um novo herói. Essa operação, que se repete inúmeras vezes na história social, está sempre aberta a novas formulações, posto que o mito, como descreve Roland Barthes, é "uma fala roubada e restituída" (BARTHES apud BUCCI; KEHL, 2004, p. 19) que, no entanto, quando "trazida de volta, não foi colocada no lugar exato" (BUCCI; KEHL, 2004, p. 79), deixando de ser o que era para se reinscrever à sociabilidade, produzindo ideologia. O mito, portanto, sequestra para si os desejos e anseios de uma coletividade e restitui tais desejos em forma de idolatria da sua imagem.

Tendo isso em vista, a ideia introduzida por Atílio na cena "Renovação de votos" de que "o Corinthians não seria um time, mas uma religião" (BRAVA COMPANHIA, 2015) é retomada nesta cena a partir de um novo ângulo. Em contraponto às formas de representação utilizadas até o momento, nas quais era possível identificar um grau de historicidade em relação à narrativa do time, nesta cena, o que está em jogo é, sobretudo, a atitude mítica e heroicizante que se contrapõe à atitude científica e histórica pertinente à ética materialista.

A própria estrutura fetichista, fundamento das religiões, atua como um escudo que protege o mito da crítica histórica de tal modo que ele se autorreproduz, em um sistema que se atualiza indefinidamente. Uma vez que os desejos por ele sequestrados são produzidos por ele mesmo e em sua própria direção, o mito é representado pela cena antes como uma atitude formal (Gestus mitificante?) do que como uma forma de 
representação na qual conteúdos diversos e variados poderiam ser apresentados e contrapostos.

A cena do santo milagreiro (que salva o time, mas entrega sua vida em sacrifício) age precisamente no ponto em que a estrutura do fetiche alimenta sua reprodução. O sacrifício de um homem que deu a vida pela causa corintiana ao proteger com o peito um tiro certeiro que daria a vitória ao time adversário é paga pelos torcedores em cena com cerveja "pro santo". O que brilha nele é o sacrifício de todas as vidas e desejos sequestrados, substituídos por uma imagem:

Tino - Virei santo e fui banhado pelo povo! Eita posiçãozinha ingrata! Ô Olho Vivo, desce um gole dessa breja aí pra mim! (Bebe). Agora vocês dão licença que vai começar a pedição. (Atores falam ao mesmo tempo, fazendo seus pedidos).

Cotonete - Gente, tá muita bagunça... Vamos nos organizar nessa quizumba! É o seguinte: vamos concentrar todos os pedidos, as necessidades, as desgraceiras... Tudo num infeliz só. Que aí vai mais rápido. E vamos fazer isso de forma democrática.

Elisa - Que nem a Democracia Corintiana, né não?

Cotonete - mais ou menos Aponta pra Atilio... Vai você, o resto vaza! Os demais reclamam! Democracia é isso aí.

(BRAVA COMPANHIA, 2015, p. 241)

Como mediador da relação com o milagreiro, vemos o personagem Cotonete, representante da igreja, propor aos populares uma forma democrática de encaminhar os pedidos. A opção de colocar Atílio, o operário, como representante dessa coletividade retoma mais uma vez o arco histórico examinado pela Brava Companhia, no qual os diversos movimentos sociais da década de 1970 convergiriam na formação do Partido dos Trabalhadores tendo como mediador o operariado, e como sustentação, a igreja católica, como sugerem Sader e Napolitano. Como já demos a entender, a formulação precedente do problema, que implicava no operariado como sujeito da luta de classes, fortalece a noção de que tal mediação corresponderia às necessidades materiais da população. Por sua vez, o que a cena nos induz a apreender na relação entre o operário e o santo milagreiro é aquilo que se compreende nas formulações mais corriqueiras como populismo.

O primeiro impasse da sequência é formulado, de partida, como problema estruturante da relação democrática. A escolha por um representante que personifique as tantas posições desenhadas ao longo das cenas já consiste em um problema estrutural. 
Em segundo lugar, de maneira cômica, a ação de Cotonete torna evidente a interferência de outras estruturas sociais, nesse caso, a igreja, que determinam o processo democrático. Por último, o pedido de Atílio por uma vitória no jogo de domingo traz a dimensão populista à tona, em sua problemática mitificante, sem fazer jus às complexidades do problema.

O populismo como forma da política brasileira somente passou a ser questionado diante das práticas trabalhistas executadas por Getúlio Vargas e por Jango, as quais, ainda que sustentadas por um aparelho repressivo do Estado, produziram efetivamente um apoio popular a essas figuras. Jorge Ferreira (2001), em O populismo e sua história, descreve o processo de consolidação de tal ideia no debate político nacional, evidenciando que, paulatinamente, seu uso foi associado à demagogia. O que ressalta o autor é que aqueles que questionavam as práticas populistas o faziam com base em justificativas conservadoras, que associavam a adesão popular a essas grandes personalidades apenas à manipulação da população, ignorando as melhorias alcançadas por tais políticas. Como descreve o autor, essa tendência parece ter sido defendida sobretudo pelas elites, que precisam subestimar as escolhas da população alegando sua “ignorância” perante os processos.

Nesse sentido, a associação entre o santo corintiano e o operariado parece, a nosso ver, induzir o olhar do espectador a uma ideia de que o problema da relação mítica e personalista implicada no populismo é apenas ingenuidade da população, e não o fato de que, efetivamente, as estruturas ditas populistas correspondem a uma satisfação real de necessidades e anseios da população. Por conseguinte, se o rebaixamento formal apresentado pela peça em seu embate com as questões sustentadas pela mitificação de personalidades pública coloca o problema, o faz apenas na medida em que os personagens ridicularizam suas próprias condutas.

Apesar disso, o problema da representação de um herói individual, e suas consequências, abre margem para o desenrolar do argumento da peça e é central para a compreensão da dimensão espetacular da política. Anatol Rosenfeld expõe que, para a existência de um herói "se fazem necessários valores circunstanciais e todo um contexto objetivo, repercussões amplas que transcendem a mera bravura subjetiva"(ROSENFELD, 1996a, p. 29). Dessa forma, a opção de elevar o pequeno operário Atílio a interlocutor remete à personificação das lutas travadas pela esquerda 
em torno de um operário, ainda que sem a necessidade de nomeá-lo. A ideia trabalhada pela peça revela, especialmente com essa passagem, a força com que os ideais populares foram tragados e reposicionados pela ideologia segundo o discurso da união popular em torno de uma imagem, suplantando toda a força da sua narrativa histórica. A mitificação de um herói implica, para o autor, na mitificação da realidade em que se situa, visto ser impossível colocar um herói mítico dentro de uma realidade empírica (ROSENFELD, 1996a). Essa atitude formal inviabiliza a compreensão do processo histórico, embora realce a crítica ao personalismo do herói.

A cena, atuando entre o sagrado e o grotesco, fecha com um banho de "cerveja" fria, depois que o Santo Tino vê Atílio, um operário em situação precária, pedir, num gesto de extremo altruísmo, que o time vença o campeonato, "pois o povo do bairro vai ficar contente" e esse é um pedido que agradaria a todos, posto que, uma vez que tudo lhes falta, nenhum outro pedido será capaz de convergir tantos desejos. Sem saber o que pensar, o próprio santo encerra o pacto da compra e venda de benfeitorias e joga na cara do operário a cerveja que havia recebido. O santo interroga o público "Santo é pra pensar? Santo é pra existir?"( BRAVA COMPANHIA, 2015, p. 242).

Em oposição a um tempo mítico, em que os desejos de toda uma população podem ser personificados por um herói, aqui operaria o tempo prosaico, no qual os valores são articulados pelos Estado e não dependem da personalidade de alguns poucos indivíduos, haja vista que "a substância, nesta fase, já não é mais propriedade individual dessa ou daquela pessoa, mas se cunhou e fixou" (ROSENFELD, 1996a, p. 29) em forma de leis e instituições reguladoras. No tempo prosaico, a reprodução da sociedade não partiria da ação de qualquer pessoa, mas de ocupações desempenhadas por pessoas e instituições que corroborariam a articulação e organização do corpo social.

Retomando os pressupostos apresentados no início do espetáculo, a formulação de uma estrutura dramatúrgica atenta à ausência de protagonistas e antagonistas como sujeitos da narrativa obriga o espectador a dar-se com o problema das estruturas produtivas que articulam o tecido social. A vida cotidiana, nesse sentido, toma proporções ampliadas, com o intuito de que seja possível reconhecer na vida objetiva os problemas a serem combatidos pelos sujeitos históricos. Com isso, a formulação prosaica e cotidiana proposta pela forma de representação da Brava Companhia, atenta sobretudo à representação das contradições, complica qualquer impulso de mitificar os 
processos sociais levados a cabo pelos trabalhadores, ainda que lhe teça homenagens, interpelando-nos com um problema que envolve a mitificação do proletariado como sujeito da luta de classes.

Em contraponto à cena mítica e assumindo a precariedade de uma cena explicativa para evidenciar ainda mais o problema, a peça fecha com uma alegoria da luta de classes contemporânea: o grande e esperado confronto entre a elite e o povo. $\mathrm{O}$ mito do sacrificio individual como valor proposto pela ideologia cristã e problematizado na canonização de Santo Tino é contraposto à ação coletiva, supondo a possibilidade de um herói coletivo ser representado. A cena que fecha o espetáculo busca sintetizar o estudo dos "Gestus populares" em uma batalha no Campo do Capital, explicitando a luta de classes em curso no seio da classe trabalhadora.

A cena abre com as figuras de Olho Vivo e do Palhaço fazendo pontuações finais acerca da peça que acompanhamos até então, como porta-vozes das denúncias feitas pelo espetáculo. Ambos reforçam o diálogo temporal e geográfico proposto pela Brava Companhia, cuja produção cultural debruça-se sobre o processo histórico com olho vivo e atenta às possibilidades e aos impedimentos do jogo. Na sequência, uma espécie de paródia da marchinha carnavalesca "Coração Corintiano" é usada para apresentar um conteúdo coletivo e revolucionário. Na música, vemos o paralelo entre o sofrimento de um coração cansado, que é trocado, mas agora não mais por um coração corintiano, pois "A multidão pediu outro coração" (BRAVA COMPANHIA, 2015, p. 243).

Reforçando a exigência de um olhar nem subjetivo, nem moralizante para a cena que virá, a canção sugere que "Sai o coração individual/ Entra o coração revolucionário" (BRAVA COMPANHIA, 2015, p. 243), alertando para que não tomemos como indivíduos os personagens representados no Campo do Capital, mas que o consideremos representantes de classe. Os personagens mudam o figurino e se preparam para o jogo. Contudo, se estávamos atentos a suas práticas e condutas, manifestas em termos gestuais ao longo de todas as cenas, não podemos nos furtar de apreender a contradição interna à classe trabalhadora que estará representada dentro da disputa, e que se conjuga também na identidade desses trabalhadores sem identidade de classe. 
Por meio do modelo de um jogo de futebol, ocorre uma disputa entre o Elite Sport High Society e o União Popular Futebol Crubi. A disputa entre os dois times figura como as regras do capitalismo se dão perante um processo de confronto social e luta. Os jogadores são os próprios populares, que se dividem entre os aliançados com a ideologia burguesa - Marcito e Gabriela, participantes do Elite, que a narração afirma tratar-se de uma Sociedade Anônima -, e o Palhaço Carne Moída, Atílio e Elisinha, integrantes do União Popular, que é representado por aqueles que não se reconhecem no gesto do empreendedorismo individual e do aburguesamento, mas no valor coletivo de suas práticas produtivas. O juiz é o personagem Moacir, o policial, representante da ordem e que, além de julgar, executa as regras do jogo. A narração fica a cargo de um repórter de campo com sua pretensa "neutralidade" jornalística, feita pelo ator que desempenha o papel de Eronides, o intelectual.

A luta no Campo do Capital é um clássico de centenas de anos e, na arena onde terá início a partida tão esperada, nos preparamos para a última cena do espetáculo. A bola, "costurada com o sangue e o suor do trabalho escravo de crianças chinesas" (BRAVA COMPANHIA, 2015, p. 244), é levada a campo e o árbitro, "arbitrário por definição" (BRAVA COMPANHIA, 2015, p. 244) cumprimenta apenas os jogadores do Elite. A execução do hino, farsesca, é um fuzilamento da bandeira nacional, mostrando que o Estado Nacional não será defendido por nenhum dos lados dessa disputa, ainda que, em um caso, é o neoliberalismo quem ganha o jogo, e em outro, a revolução. Na falta de uma moeda para o jogo ter início, o Elite "salva a Pátria" (BRAVA COMPANHIA, 2015, p. 244) quando Marcito oferece um bom suborno e uma moeda que permite o cara ou coroa em beneficio do próprio time. A partir daí, o juiz apita todos os lances sempre seguindo as regras que favoreçam o Elite Sport High Society, inclusive recorrendo a mudanças abruptas na legislação, alterando-a de modo a contribuir para a sua vitória.

Olho Vivo, que no início da cena despede-se do Teatro Popular União e Olho Vivo para cumprir, agora, outra função, torna-se o comentarista do jogo, encarregado de explicitar as manobras da cena e estabelecer paralelos entre os lances que acompanhamos e as movimentações do mercado e das lutas populares. A graça vem de sua característica bastante esquemática, que recorre a diversos chavões da comédia clássica e à exploração de uma linguagem futebolística que compõe uma narrativa a 
partir da qual podemos ter um segundo olhar para as dificuldades de organização popular. Não mais atenta às interações entre os indivíduos, como é o caso de todo o "Primeiro Tempo", mas à conjuntura política, a narração e os comentários do jogo contribuem para o quadro geral apresentado no "Segundo Tempo", e aqui vemos, sobretudo, as forças sociais em confronto no campo.

A retomada do procedimento paródico, que mimetiza de maneira cômica as regras e os modelos implicados em um jogo de futebol, contribui para problematizar a própria noção de confronto subscrita na metáfora. Se as regras implicadas nesse confronto não viabilizam o jogo justo, será que essa é a forma social capaz de virar este jogo? Todavia, o recurso também aproxima concretamente o público popular dos termos da luta de classes, dado o total reconhecimento e identificação com as regras de um jogo de futebol. Esse didatismo é fundamental para uma parcela do público, que acaba por envolver-se empaticamente com os pressupostos da luta de classes. Contudo, tendo em vista que os jogadores, ainda que subjugados pela ideologia da elite, são todos populares, trabalhadores e trabalhadoras que respondem, obrigatoriamente, a essas regras, será que o confronto não deveria se dar em relação ao próprio jogo, impedindo que suas regras se propagassem?

A estratégia do Elite, que aposta nas individualidades e joga pela direita, mas sabe aproveitar as brechas deixadas pela esquerda é contraposta à falta de organização e trabalho de base do União Popular, que mantém sua desvantagem histórica, fazendo com que, em todos os lances que se aproximam do gol, não haja jogadores prontos para receber a bola (BRAVA COMPANHIA, 2015).

A estrutura apresenta um quadro crítico que visa demonstrar a dialética entre ordem e desordem de um ponto de vista periférico, tornando ainda mais visível o fato de que a própria organização do Estado de Direito não contribui para os avanços sociais decisivos. Na cena, a integração à "ordem" e às regras do jogo parece apontar sempre para uma otimização da exploração e para a supressão da luta, dando a ver a perspectiva ideológica que faz com que as regras da competição sejam contingentes e incorporem a exceção como acordo tácito. Até mesmo a "falta" marcada injustamente contra o Elite é reprisada, forjando um rancor e uma violência extremos na ação dos jogadores do União Popular, que não corresponde à realidade. Olho Vivo faz a ressalva de que "parece até 
montagem... Vejam o que a TV é capaz de mostrar pra gente" (BRAVA COMPANHIA, 2015, p. 246), e, na cobrança do pênalti, um tumulto se instaura em campo.

Durante a pancadaria, o Elite recua e deixa os jogadores do time adversário brigando entre si, em uma selvageria que remete tanto às lutas internas da esquerda, quanto à disputa selvagem imposta pelo neoliberalismo. Em qualquer um dos casos, a tropa de choque é convocada para restituir a ordem e dar andamento ao jogo, acuando o União Popular "na periferia do Campo do Capital" (BRAVA COMPANHIA, 2015, p. 246). Nesse momento, Atílio, vê uma brecha e, sozinho, assumindo a estratégia personalista do Elite, se lança para marcar o único gol do União Popular que "anima a luta de um time historicamente massacrado" (BRAVA COMPANHIA, 2015, p. 247). Olho Vivo reage com ânimo estimulando o time "é possível, existem brechas!!! Vamos lá União! De pé, de pé! É o povo quem mais ordena!” (BRAVA COMPANHIA, 2015, p. 247), para, na sequência, a tropa de choque voltar à cena e acertar o jogador, que cai morto no gramado. A bala que o atinge é representada pela própria bola e a cena silencia com o corpo caído no chão.

Será que há brechas dentro desse jogo? A violência, seja por parte da tropa de choque, seja por parte do União Popular que age contra eles próprios, é reflexo de uma violência maior e constitutiva de nossa sociedade, inscrevendo na desigualdade social e na geografia da cidade uma barreira que separa materialmente e objetivamente o campo de lutas desenhado pelo Capital. Por outro lado, a representação dessa violência como roubo de tudo aquilo que constitui a identidade dos indivíduos - seja através de sua classe, de sua raça, de gênero ou de time, vê-se apenas uma imagem transformada em mercadoria fetichizada pela Sociedade do Espetáculo - efetiva uma segunda expropriação, que coloniza o imaginário, convertendo nossos desejos de transformação e de luta em mito de um possível combate final. Nesse processo, o sacrifício pode tomar parte como forma de reforçar a ideia de "um por todos, todos por um" presente na estrutura cristã, que aposta nas individualidades e nos personalismos para se sustentar dentro da sociedade capitalista. Com isso a apropriação da narrativa da vida ou da morte de um indivíduo na luta apaga, em certa medida, seu valor coletivo, reificando o próprio processo. A atitude narrativa que se oporia a esta deve, portanto, assumir a perspectiva modelar, e não a especular, levando em conta o processo para compreender a contradição gestual, sem que haja um tratamento heroico de quaisquer atores sociais. 
Ainda que no conjunto da cena também pudéssemos compreender o problema como se Atílio representasse um herói coletivo, aclamado como $o$ operariado ou $o$ trabalhador organizado, o impasse permaneceria latente diante da atual conjunção de forças do neoliberalismo. Atento a isso, a noção de herói coletivo criticada por Anatol Rosenfeld (1996a) aponta para a incongruência tácita do enunciado, que evidencia um problema intrínseco às narrativas espetaculares e midiáticas pautadas por essa estrutura de significação mítica. O autor ressalta que o ato heroico é necessariamente singular, já que "a ampliação do número de heróis aniquilaria a sua condição excepcional de herói. Mesmo se se admitisse a sua multiplicação indefinida, isso seria de pouco valor" (ROSENFELD, 1996a). Contudo, é não no valor do herói, mas no valor do trabalho coletivo que se pode forjar uma luta contra o sistema, dada a dimensão prosaica com que se articulam os campos de força.

Nesse sentido, a exigência feita pela peça de evidenciar a participação e a implicação de todos dentro do acontecimento estético contribui como uma nova forma de representar o problema. Consideramos essa uma atitude didática, não na acepção pejorativa com que o termo é utilizado, mas no sentido político preconizado por Brecht e ressaltado por Jameson (1999) em "Brecht e a questão do método". Ainda que a afirmação possa gerar controvérsias, a noção aqui é de que o Gestus coletivo criticável na cena é a manutenção da expectativa de atos heroicos, o que evidencia que a luta contra o sistema capitalista perdeu seus lastros sociais mais sólidos, descolando-se da prática cotidiana. Nesse sentido, seria a aparência da luta, e não o trabalho sistemático junto ao corpo social, o fundamento da separação.

Não obstante, o espaço político produzido pela peça, associado ao debate crítico, busca a empatia do público com o valor coletivo do trabalho e com a sua produção, o que é um ganho formal. Para concluir a peça, o Palhaço entra em cena e com os dizeres "Levanta povo" (BRAVA COMPANHIA, 2015, p. 247) e tenta ainda reanimar o parceiro de luta, que permanece inerte no chão. Percebendo sua inação, coloca sobre ele sua peruca, instaurando uma melancolia na cena.. Elisinha, a torcedora símbolo do time, fecha a cena, seguida de uma canção que se volta para a memória de um passado que não aconteceu.

Elisinha - É o fim do jogo! Pra uns a festa começou e não tem fim! Pra mim a festa 
acabou! Eu tenho um sentimento de saudade, sabe? Mas por coisas que ainda não aconteceram. O que tá aí é repetição, é jogo marcado. Eu não tenho saudade.! Como eu queria ter saudade! Poder agitar uma bandeira com escritos escolhidos...Por nós. Tenho saudade de coisas que ainda não vivi...

Olho Vivo - Que ainda não vivemos... que ainda não viraram ...Saudade (BRAVA COMPANHIA, 2015, p. 247).

O exame histórico de um passado de luta, suprimido inúmeras vezes, termina apontando para o futuro com base na crítica ao processo histórico da esquerda nacional, e apropriando-se de seu repertório de maneira modelar. A ideia que encerra a narrativa é negativa, benjaminiana na medida em que alude à luta dos vencidos: apenas possibilita a transcendência a partir daquilo que "não foi" e que, portanto, não pode ser apropriado como imagem pela Sociedade do Espetáculo. Essa atitude vai de encontro aos diferentes mitos heroicos apresentados (e criticados) pela peça, que ocupam em nosso repertório os postos de heróis da esquerda, e que geralmente não são lidos a partir de seus erros e contradições, mas tão somente a partir de uma atitude igualmente idealista, calcada em uma falsa coerência total.

A ação historicizante da obra encerra-se, contudo, mantendo o campo aberto para novas investidas, convocando o imaginário das lutas de resistência sucessivamente massacradas ao invés de reforçar o mito de parcas vitórias populares. Nesse sentido, a ação é dialética, pois associa luta e resistência (as quais, a contrapelo, movem o mundo) à destruição das estruturas que movem o Capital. Com isso, porém, não suscita a ideia de que os indivíduos que se lançam nessa batalha possam ser, eles próprios, heróis que, ao serem alçados ao lugar de mitos, congregariam os elementos simbólicos e desejos dos quais se alimenta a luta.

O grande jogo, a grande final, talvez não venha, ainda que a luta de classes e os antagonismos implicados nela permaneçam latentes. A crítica aos processos, no entanto, não pode dar margem a idealizações, uma vez que não se pode aproximar-se de um legado deixado pela tradição sem apontar suas contradições, ainda que sejam ideias sustentadas por aspirações igualitárias e por intenções revolucionárias. Talvez o grande jogo esteja em curso. 


\section{Conclusão}

A maior homenagem que se pode prestar ao trabalho de uma geração é a tentativa de dar continuidade ao seu projeto, assumindo para si as implicações da crítica a seus erros e enganos, mas, sobretudo, mantendo a atitude de resistência e de militância diante de uma sociedade que sucumbe por ainda não ter superado suas desigualdades. Os limites e os avanços de cada etapa desse projeto, que só pode persistir na medida em que se torna coletivo, são a matéria-prima com a qual cada momento histórico deve haver-se para cumprir tal empreitada. É isso que torna um projeto artístico capaz de ultrapassar seu próprio tempo.

Corinthians, meu amor - segundo Brava Companhia - Uma homenagem ao Teatro Popular União e Olho Vivo dedica-se, como buscamos comprovar, a essa importante tarefa. Ao lançar nossos olhares à imprescindível intervenção e presença de grupos teatrais, como o Teatro Popular União e Olho Vivo, junto ao front da luta de classes, a Brava Companhia realiza o necessário gesto de retomada de uma memória de luta e resistência cultural. Tal gesto só se torna possível por propor a

[...] outros uma associação organizada e consciente em torno de um projeto coletivo e que só pode ser concebido e realizado coletivamente. Vale dizer: o texto inaugura a prática que ele mesmo teoriza, justifica e propõe, e desta forma a demonstra, por assim dizer, na prática (PASTA, 2010, p. 53, grifos do autor).

Essa atitude implica em contrapor uma tradição crítica a outra tradição, muitas vezes de cunho classista, que precisa ser destruída. Apenas do confronto entre ambas é que novas formas poderiam surgir. Trata-se, portanto, de atuar para manter viva essa tradição crítica, mesmo quando o campo de lutas parece pender para uma derrota inexorável do embate.

A retomada do trabalho do grupo Teatro Popular União e Olho Vivo pela Brava Companhia, conforme procuramos apresentar, parece contribuir para a reposição no tempo não apenas dos pressupostos do grupo homenageado, mas, principalmente, de todo um debate estético que tem por base a problemática das questões de classe e, principalmente, um histórico de lutas sociais que emergiu dessa questão. Ainda que o desenvolvimento do capitalismo mundial pareça estar ofuscando o problema, e 
considerando-se o fracasso do "socialismo real" - que, associado aos avanços neoliberais, fez com que os horizontes revolucionários se esfumaçassem -, o impasse não desapareceu e parece longe de encontrar uma solução. Nesse sentido, torna-se mais do que necessário assumir a cultura como um front de disputa de imaginários, posto que, como afirma Pasta:

\begin{abstract}
Este campo, se não é jamais um campo neutro, mas sempre sacudido por tensões contraditórias, tampouco é apenas um aglomerado caótico. Ele se organiza, na base, através de um sistema de referências privilegiadas, autores incontornáveis que, mesmo em estado de tensão e luta, encontram-se sempre em contínua homeostase. Este equilíbrio tampouco é neutro, mas sempre o produto de uma triagem complexa, que opera por conferir distinções e impor recalcamentos, por recuperar e obliterar. Para Brecht essa triagem é sempre operada por um sujeito coletivo e de classe, mais precisamente, pela classe dominante (PASTA, 2010, p. 40).
\end{abstract}

Tendo isso em vista, assumimos como ponto de partida para nossa leitura do espetáculo da Brava Companhia algumas proposições e interpretações acerca do trabalho de Brecht, especialmente aquelas elaboradas por José Antonio Pasta, que se tornou para nós uma referência incontornável para a compreensão do espetáculo. A teoria do autor, que defende como cerne da produção de Brecht a ideia de "valor coletivo", foi determinante para que pudéssemos apreender a relevância das configurações formais da companhia à luz de uma pesquisa estética que tem como pressupostos os expedientes do teatro épico.

O que nos inquietava, por um lado, era a maneira como a proposição formal da Brava Companhia se relacionava com o teatro épico tal qual lido pelos principais intérpretes brasileiros do trabalho de Brecht. Por outro lado, incomodava-nos também a maneira como a tradição do teatro épico nacional se relacionara com a matéria-prima de uma cultura popular que não chegou a consolidar um sistema literário, sendo, portanto, calcada em técnicas populares e performativas, como a música, as danças e festas, os esportes e, primordialmente, a indústria cultural.

Nesse sentido, o sistema de referências culturais articulado pelas classes dominantes parece ter otimizado a reprodução do sistema capitalista por meio da indústria do entretenimento, enquanto as formas críticas a esse sistema não tiveram o mesmo enraizamento junto aos trabalhadores, justamente porque a lacuna entre os 
artistas e o público presumia uma tradição literária que não comportava a tradição cultural de uma população não letrada.

Essa realidade, a qual se tentou combater de diversas maneiras, apenas passaria a ganhar uma formalização que tivesse por base a relação com esse público a partir da década de 1960, por intermédio da ação dos Centros Populares de Cultura, os CPCs, que, para Iná Camargo Costa, são o auge do projeto estético-político do teatro nacional. (COSTA, 2012) Devido aos seus pressupostos terem sido também amparados pela luta de classes, as propostas do CPC foram violentamente interrompidas pelo Golpe Militar, ainda que permanecendo em nosso imaginário como fantasmagoria idealista de uma luta perdida, dado o sentimento de derrota que acometeu os artistas que se engajaram no projeto.

No entanto, quando assumimos a perspectiva histórica e o "valor coletivo" como base para um projeto cultural de longa duração, como sugerido por Pasta (2010), podemos observar que as proposições do CPC contribuíram concretamente para os avanços críticos e estéticos alcançados pela produção cultural nacional. A retomada, portanto, de formas estéticas pertencentes a uma tradição teatral com viés crítico e a confrontação dessas formas com outras, pertencentes às classes dominantes, parecem fundamentar a pesquisa estética da Brava Companhia na montagem de seu Corinthians, meu amor. O recurso trabalhado pela companhia, a contra-imagem, configura-se portanto como um procedimento dialético de construção do espetáculo. Esse procedimento procura, formalmente, maneiras para destruir as perspectivas de representação que subjugam as questões de classe, combatendo seus sofisticados procedimentos de produção ideológica ao sobrepor a eles tentativas de resistência.

Com isso, reconhecemos que, de maneira latente, tais formas combativas parecem ter sobrevivido e estão inscritas no trabalho de diferentes grupos. Assim, uma tradição crítica dialética permanece ativa na contribuição para o sistema cultural que se forma no país, talvez menos pautado pelos autores, e mais por práticas épicas, intensamente relacionadas com o tecido social a ser representado. Espetáculos como o da Brava Companhia revigoram o debate acerca do trabalho de Brecht e de tantos outros artistas engajados com a crítica ao sistema capitalista por elucidarem pressupostos éticos e estéticos que nos obrigam a enfrentar a luta de classes como algo que não ficou no passado, ainda que exija atualizações de seus enunciados. 
Essa ação apenas poderia se dar a partir dos pressupostos coletivizantes subscritos no trabalho de Brecht. Nesse sentido, o gesto de formar e combater o sistema cultural burguês produziria contradições e impasses diversos para os artistas engajados com a representação do popular, impondo problematizações distintas daquelas encontradas por Brecht no tocante ao seu trabalho.

Ao retomar do trabalho do Teatro Popular União e Olho Vivo não apenas suas proposições formais ou temáticas, mas o sentido político de articulação e militância junto aos trabalhadores, a Brava Companhia assume para si a responsabilidade em ato de posicionar na história uma ação de produção de sentido no que se refere às lutas sociais e ao fazer artístico. A proposição modelar implicada em todo o trabalho de Brecht, portanto, presume o confronto entre as formas de representação hegemônicas e contra-hegemônicas como cerne da sua produção, como propõem Pasta (2010) em sua análise. Tal procedimento é o princípio organizativo que articula todo o sistema de símbolos e imagens do espetáculo da Brava Companhia e fricciona no corpo da peça o trabalho do grupo também fora de cena. Tendo isso em vista, a obra precisa lidar, ainda, com uma relação direta com o seu público e com o tecido social para se fazer valer, implicando-se em um sistema complexo de representação. Este, o mesmo gesto de recuperação do projeto do CPC encampado pelo TUOV e por uma parcela dos grupos de Teatro da Militância durante os anos de chumbo, pressupõe a sua reposição no tempo, assumindo o confronto com seu próprio contexto político e social. Apenas assim poder-se-ia alcançar uma efetiva ação coletiva e a formação de um sistema cultural crítico.

Admitindo tais pressupostos, nossa pesquisa dedicou-se a compreender quais foram as formas sociais representadas pela peça em face dessa tradição. O primeiro capítulo buscou apresentar a trajetória do grupo homenageado e a maneira como ele se inscreveu na história do teatro popular no Brasil: a formação do grupo, sua participação no movimento de esquerda que emergiu durante a década de 1970, sua contribuição e participação junto às greves e na formação do Partido dos Trabalhadores. Também, a atuação militante de seus integrantes ao lado da sociedade civil na formação da Cooperativa Paulista de Teatro e no movimento Arte contra a Barbárie, e o ativismo junto ao movimento de teatro de grupo. Os temas levantados nesse capítulo foram, 
sobretudo, apontamentos para uma perspectiva nova de leitura acerca do período histórico atravessado pelo TUOV, que não foram aprofundados por essa investigação.

No segundo capítulo, passamos a analisar o ponto de vista adotado pela Brava Companhia para reposicionar as questões levantadas pelo Teatro Popular União e Olho Vivo. Reconhecemos o ponto de vista do Coringa Olho Vivo como uma perspectiva formal que presume tanto as influências da produção cultural da década de 1960 sobre o trabalho do grupo homenageado, quanto os reflexos do trabalho do TUOV sobre a Brava Companhia.

Ao assumir esse ponto de vista organizativo, a peça realiza, na prática, a recuperação de uma memória de teatro popular e militante que não pertence ao seu público imediato, mas que foi produzida para e com fins de ação militante junto a esse público. Apreendemos daí o cerne da ação coletivizante proposta pela Brava Companhia, por meio do qual o grupo tira consequências de uma tradição crítica e dialética que sempre teve como horizonte a integração das classes trabalhadoras no aparelho cultural. Tendo isso em vista, o uso diverso do Sistema Coringa de Augusto Boal, como o realizado pela Brava Companhia, apenas se tornou possível a partir de uma transformação efetiva no sistema de produção cultural da cidade. Essa transformação somente foi possível devido às novas formas de organização política propostas pelos movimentos sociais e culturais que realizaram um amplo trabalho de base ao longo da década de 1970, dentre eles o Teatro Popular União e Olho Vivo.

No terceiro capítulo, buscamos analisar o recurso da paródia como fundamento de uma teatralidade que permite o uso das distintas formas culturais confrontadas pelo espetáculo de maneira crítica. Identificamos, com efeito, que o enunciado temático parodiado criticamente é a ideia abstrata de "união popular". Tal conceito, a nosso ver, parece dificultar a visualização de um impasse relativo à própria identidade de classes, embasando o problema central do espetáculo, ou seja, a dificuldade de mobilização política por parte da população. A incompletude da paródia, nesses termos, presume uma união, ou uma formação, que não se completa, sendo sempre incorporada pelo espetáculo, ou seja, organizando a estrutura da narrativa a partir de rupturas sequenciais. Essas rupturas são encaradas como uma questão a ser desenvolvida pela dramaturgia e pela encenação, configurando o corpo do problema representado pela peça - e que precisa ser superado pela política. Não à toa, as cenas que estruturam o eixo dramático 
do espetáculo são chamadas de "Organização interrompida" e "Peça interrompida". A representação do processo de formação de sujeitos históricos, que se daria tão somente por meio da luta, não consegue se concluir graças às diversas interrupções no corpo da narrativa. Tais interrupções refletem as inúmeras rupturas no curso da história política do país.

Nesse sentido, o recurso da paródia separa o espetáculo teatral do processo real de organização política no qual a Brava Companhia busca se engajar. O procedimento vigora contrapondo diversos modelos, sejam eles estéticos, culturais, sociais ou mercadológicos. Tais formas de representação e modelos precisam ser encarados e subvertidos por meio de procedimentos críticos caso se queira encarar um projeto militante junto às classes trabalhadoras, como exposto pelo próprio Brecht:

\footnotetext{
É aqui que surge a questão da herança. Trata-se de passar no crivo as obras legadas pelo passado, obras de uma cultura que era dominada por uma outra classe, uma classe inimiga, mas que cobre absolutamente tudo o que foi produzido até este dia; estamos diante, aí, do último estágio atingido sob a dominação e o controle da burguesia, mas também do último estágio atingido pela evolução humana em geral. É claro que, neste caso, em seguida a uma vitória, numa situação na qual os combates que ficam por livrar podem ser realizados numa posição de superioridade, onde toda a infraestrutura econômica e política da cultura se encontra refundida numa velocidade impetuosa em direção ao socialismo, o exame crítico das produções da cultura burguesa difere daquilo que ele deve ser na época dos combates que precedem a vitória (BRECHT apud PASTA, 2010, p. 41, grifo do autor).
}

Nessa passagem, em que o dramaturgo tece considerações sobre as heranças culturais com as quais seu projeto deve se haver, torna-se evidente que a vitória não chegou. Todavia, o fato de estarmos diante de um novo momento do processo obriganos a avaliarmos com ainda mais atenção os deslocamentos no campo cultural dado o confronto entre as formas sociais militantes e as formas burguesas. Todas as formas à disposição podem ser incorporadas por qualquer um dos lados da disputa, fato este que exige do pensamento ainda mais atenção analítica.

Assim, o recurso da paródia foi determinante para se compreender a retomada crítica dos temas por meio da forma, pressupondo um jogo de leitura dos conteúdos por parte do público que se origina em pressupostos compartilhados. Com base em uma herança cultural popular que em parte foi expropriada pelo sistema hegemônico, em parte resiste, impondo-lhe oposições, reconhecemos o corpo do problema impregnado 
na noção de "popular", sobretudo porque se mantém aí uma tensão terminológica pelo fato de o termo ser também amplamente explorado pela indústria de massas.

No quarto capítulo, buscamos abordar a relação entre essas diferentes culturas produzindo gestus diversos. Analisamos quais são os tipos representados pela peça, buscando compreendê-los dentro de diversos sistemas de representação. Tomamos como ponto de partida histórico a década de 1970 e seus atores sociais. A instituição artística, ao que tudo indica, é o foco central do espetáculo e aparece representada pelo nosso Coringa Olho Vivo, que se opõe diretamente à indústria cultural.

Por intermédio de deslocamentos ocorridos na representação dos personagens populares no período, identificamos uma mudança substancial no sistema cultural, fruto também da ação, em sentido oposto, dessas duas vertentes de atuação. O primeiro ponto deslocado da dramaturgia de 1966 foi a expectativa otimista implicada na formação de uma indústria cultural, dado este que é amplamente problematizado na montagem contemporânea. Os elementos formais encontrados por César Vieira partem desse otimismo, embora conjuguem enunciados que criticam esse sistema de representação. Esse é o caso da Câmera Gabriela que, dentro da dramaturgia original, age na transformação da narrativa em sentido épico.

$\mathrm{Na}$ sequência, observamos a transformação no modo de representar o trabalhador e o mundo do trabalho proposta pela dramaturgia. O pressuposto de uma sociedade de classes, que, todavia, não é mais representada no espaço de trabalho, mas na cidade, pareceu-nos determinante, seja para a compreensão do deslocamento ocorrido nas lutas populares no período da ditadura, seja para analisarmos as transformações no escopo do trabalho contemporâneo e do trabalho com a cultura, em meio a implicações neoliberais.

As relações que tais personagens tecem entre si, com o Estado, com o mercado e com a vida cotidiana compõem o corpo do problema graças à preponderância da indústria cultural como força que age para unificar as massas, impedindo que elas se formem como sujeitos históricos. Identificamos que a configuração do gestus de cada um dos personagens visa representar criticamente a composição diversificada da população e sua heterogeneidade, assumindo relações distintas com as institucionalidades mais atuantes nas periferias da cidade. Nesse sentido, o recurso à parodia recupera a centralidade na representação tanto ao possibilitar a incompletude 
dos gestus na relação com o público, quanto ao selecionar apenas uma dimensão desses personagens a ser avidamente criticada e destruída, remetendo ao grotesco.

Por último, encerramos nossa análise lançando algumas hipóteses sobre as formas encontradas pela Brava Companhia para coletivizar os processos de luta social e resistência. Problematizando o confronto entre a indústria cultural e a cultura contrahegemônica com função militante, analisamos as implicações das escolhas formais da Companhia no todo da obra.

Tendo claros seus elementos estruturantes - a paródia das formas culturais e sociais, o estudo dos gestus e o ponto de vista histórico da obra, mediado por uma tradição crítica com expectativas militantes do trabalho -, em todos os sentidos, o que foi trabalhado pela companhia poderia ser classificado como uma "modelização coletivizante" (PASTA, 2010, p. 27) da produção artística.

Ao tomar como ponto de partida para esta pesquisa o objetivo da companhia de intervir no aparelho produtivo burguês, buscamos evidenciar as relações entre contexto político e social, associando-os à representação simbólica desses elementos no corpo da obra. A expectativa da pesquisa era buscar formas estéticas de intervenção nos coletivos militantes que pudessem ser, ao mesmo tempo, instrumento de organização política e crítica dentro dos movimentos organizados.

A hipótese, que assumimos como incompleta no corpo analítico dessa pesquisa, ainda exige uma investigação mais ampla de seus pressupostos. Todavia, no curso deste trabalho reconhecemos a necessidade de aprofundamento em aspectos relativos às peças didáticas de Brecht, bem como uma maior compreensão acerca do movimento de teatro de agitprop. A importância inequívoca que a bibliografia sobre o tema, ainda que reduzida, teve sobre nossos resultados convida-nos a ir mais a fundo nessa pesquisa e tornou-se um norte para que possamos ampliar nossa compreensão sobre o todo do trabalho do autor. Nesse sentido, encontram-se aí os próximos temas a serem investigados pela pesquisadora.

A hipótese levantada por este trabalho, de que haveria uma relação entre as peças didáticas de Brecht e o trabalho da Brava Companhia, presume o diálogo e o conhecimento construído na relação com o seu público como partes do projeto coletivo de refuncionalização do aparelho cultural. Esses elementos, fundamentais para a estrutura do espetáculo Corinthians, Meu Amor - Segundo a Brava Companhia - Uma 
homenagem ao Teatro Popular União e Olho Vivo, apontam para novas proposições formais com base no reconhecimento do lugar de autores e produtores por parte de toda a coletividade presente no corpo do espetáculo. O fato de essa prescrição estar não apenas na atitude processual da companhia, mas aparecer formalmente no corpo do espetáculo produz uma autonomia para o discurso que incorpora o público à sua atitude militante, como um sistema que se pretende autônomo. Embora esteticamente isso nos pareça um ganho formal, ainda muito há de ser feito para que a organização avance rumo a uma coletividade ainda mais ampliada, expondo aos presentes suas próprias ações e possibilidades.

Com efeito, o valor coletivo do trabalho de Brecht encontra balizas sobretudo na sua contribuição para a formação de um sistema cultural crítico. $O$ fato de o autor não apenas propor os termos a serem debatidos por seus estudiosos e seus críticos, mas também organizar a inscrição de seus trabalhos dentro do campo social é determinante para o alcance de seus trabalho. A partir dessa prerrogativa, a seleção dos autores que foram pesquisados e aprofundados nessa análise deu-se por meio das suas próprias publicações organizadas nos Cadernos de Erros da Brava Companhia. Autores como Iná Camargo Costa e Sérgio de Carvalho, imprescindíveis no que se refere à participação do trabalho de Brecht no Brasil, somados a referências como Maria Rita Kehl, Eugênio Bucci e Guy Debord, passaram a nortear nossa análise no que se refere aos caminhos teóricos e reflexivos que sustentam a criação do espetáculo.

Não podemos nos furtar de dizer que, em especial, as descrições das práticas militantes do grupo, as Bravas Conversas realizadas com organizações e moradores da região, e um trabalho de campo pouco sistematizado, mas realizado durante toda a pesquisa, orientaram nossos caminhos para que pudéssemos nos aproximar não apenas da realidade produtiva do grupo, mas também da produção intelectual e crítica que está sendo produzida na própria periferia. Essa aproximação exigiu inúmeros filtros críticos para que não incorrêssemos em problemas relativos a idealismos ou preconceitos no tocante a essa produção.

Tendo isso em vista, a organização do material crítico ao qual devemos e podemos recorrer para nos aproximarmos de uma obra artística pressupõe que, em seu valor coletivo, estão inclusas a seleção e a identificação das perspectivas críticas que 
precisam ser sustentadas em face de tantas influências que são recebidas e combatidas no campo da cultura. Como afirma Benjamin,

\begin{abstract}
A melhor tendência é falsa quando não prescreve a atitude que o escritor deve adotar para concretizá-la. E o escritor só pode prescrever essa atitude em seu próprio trabalho: escrevendo. A tendência é a condição necessária, mas jamais a condição suficiente para o desempenho da função organizatória da obra. Esta exige, além disso, um comportamento prescritivo, pedagógico, por parte do escritor.[...]. Um autor que não ensina nada aos escritores não ensina ninguém.[...]. O caráter modelar da produção é, portanto, decisivo: em primeiro lugar, ela deve poder orientar outros produtores em sua produção e, em segundo lugar, colocar à disposição deles um aparelho mais perfeito. E esse aparelho é tanto melhor quanto mais conduz consumidores à esfera da produção (BENJAMIM, 2016, p. 141).
\end{abstract}

Nesse sentido, o projeto de Brecht é épico não apenas na forma narrativa, mas em sua conjugação temporal, estendendo-se ao longo do século XX e atingindo-nos por meio de uma performance no tempo - a performance de um clássico que busca se confrontar com uma sociedade de classes. Como representado na cena final, o jogo entre o Elite Sport High Society e o União Popular Futebol Crubi carece de bandeiras novas forjadas a partir do atual momento da história político-econômica: um neoliberalismo avançado que transforma a todos em proletários e empreendedores de si mesmos, atingindo o mais alto grau de individualismo. Novas práticas e atitudes militantes, portanto, apenas podem ser criadas opondo-se a essa realidade por meio de seu valor coletivo ante um processo histórico de luta e resistência. É apenas na performance coletiva, com valor histórico e integrada ao corpo social, que o jogo pode mudar. No limite, o objetivo é a transformação do real, da realidade comum, por intermédio de uma arte crítica - e, para tanto, é preciso implicar a presença do teatro e da cultura na vida dos espectadores, não apenas como consumo, mas como produção de realidade.

A comunhão, por conseguinte, tal qual representada pela peça, que se dá na relação com o cotidiano periférico e de onde o grupo engendra os principais paralelos com o processo histórico promovido pelo Teatro Popular União e Olho Vivo, amplia-se para o movimento de teatro de grupo e de ação político-cultural nas periferias, ou seja, para os movimentos militantes, incitando essa possibilidade. Opondo-se ao embate protagonizado por "populares" - representantes de uma mesma classe -, temos, de maneira alegórica, a dimensão ideológica do problema, que consiste na concorrência e 
na disputa entre iguais como impasse a ser superado para se contrapor a um sistema econômico opressivo como o neoliberalismo.

Com isso, as perguntas feitas por Walter Benjamin (2012) exigem, pois, respostas no corpo do trabalho artístico. Tanto "qual é a posição de uma obra literária em relação às relações de produção da época?", quanto “qual é a sua posição dentro dessas relações?” (BENJAMIN, 2012, p. 131) são questionamentos necessários para apreendermos a "função exercida pela obra no interior das relações de produção literárias de uma época. Em outras palavras, [elas visam] de modo imediato à técnica literária das obras" (BENJAMIN, 2012, p. 131).

Assim, apenas na medida em que a obra se coloca dialeticamente em confronto com a sua realidade, incorporando como valor a produção coletiva do real e produzindo a destruição de um lugar mitificado de representação do popular como algo uniforme, calcado em perspectivas individualizantes, é que ela destrói a si mesma, quase como um réquiem para um processo histórico que se fecha, projetando novos futuros.

Dessa forma, ao reconhecer suas origens, seu público e as questões que estão postas para a produção cultural contemporânea, a companhia tem condições de tecer acerca deste contexto social vivo uma representação autocrítica. No mesmo sentido, ao associar-se à perspectiva de Olho Vivo, o grupo encontra formas para reposicionar um debate cultural que já parece também pertencente a um outro tempo, ao mesmo tempo em que critica sua realidade imediata, produzida por esse mesmo passado.

O fato de, em 2012, Corinthians, meu amor - segundo Brava Companhia - Uma homenagem ao Teatro Popular União e Olho Vivo registrar o fim de um tempo para o teatro de grupo representa algo de primeira importância acerca do processo político nacional. As subsequentes rupturas na política nacional figuradas pela peça inviabilizam, de certo modo, o avanço da crítica, dando corpo ao problema. Pudemos mais uma vez tomar contato com impasses e ter uma dimensão aproximada da sua amplitude diante dos avanços liberais com os quais nos deparamos a partir de 2013. O movimento histórico de ampla movimentação popular que culminou com as jornadas de junho de 2013 e que lutava, sobretudo, pela ampliação de direitos sociais, acabou ganhando contornos neoliberais ainda mais fortes, obrigando-nos a compreender a força com que o mercado já articulara suas redes de proteção. 
As dificuldades encontradas pela pesquisa, principalmente nessa etapa de finalização, dão-se exatamente por essa mudança drástica no quadro político nacional. O impeachment da Presidenta Dilma Rousseff em 2016 e os cortes de direitos sociais (que pareciam consolidados) efetivados pelo governo de Michel Temer, nos colocou novas questões a respeito da produção artística e das possibilidades organizativas dos movimentos da esquerda. Tal realidade exigiu também desta pesquisa um posicionamento ético e político que pudesse se colocar em diálogo com esse momento da política nacional. Nesse sentido, um projeto coletivo torna-se ainda mais urgente e evidencia-se a necessidade de novas formas de representação para fazer frente à atual organização do capitalismo global.

A urgência de que a produção cultural retome uma atitude crítica diante do real (atitude realista e científica sugerida por Brecht), reconhecendo o seu lugar na sociedade neoliberal e retomando, ou melhor, inventando um novo lugar para sua atuação militante, depende de uma atitude comprometida de todas as partes envolvidas na produção da cultura. Tal impasse apenas pode ser superado caso se leve em conta a complexidade da inscrição dessa produção cultural e de seu papel na vida ideológica. 


\section{Referências bibliográficas}

AGAMBEM, G. Profanações. São Paulo: Boitempo, 2007.

ALMADA, I. Teatro de Arena: uma estética da resistência. São Paulo: Boitempo, 2004.

ANDERSON, B. Comunidades imaginadas: reflexões sobre a origem e a expansão do nacionalismo. São Paulo: Companhia das Letras, 2008.

APPIA, A. A Obra de arte viva. Lisboa: Arcádia, s/d.

AQUINO, M. O invasor. São Paulo: Geração Editorial, 2002.

ASSANO, Gustavo Takashi Moraes. Teatro irresoluto: impasses do teatro subvencionado na encenação do espetáculo Oresteia - o canto do bode pelo grupo teatral Folias D'Arte. Dissertação de Mestrado. Faculdade de Filosofia, Letras e Ciências Humanas, Universidade de São Paulo, São Paulo. 2016.

ARANTES, P. Sentimento da dialética na experiência intelectual brasileira: dialética e dualidade segundo Antonio Candido e Roberto Schwarz. Rio de Janeiro: Paz e Terra, 1992.

. Zero à esquerda. São Paulo: Conrad, 2004.

. Extinção. São Paulo: Boitempo, 2007a.

. Um pensador na cena paulistana. Estado de São Paulo, São Paulo, 15 jul.

2007b. Disponível em: http://cultura.estadao.com.br/noticias/geral,leia-texto-doconvite-e-trecho-da-entrevista-com-paulo-arantes,33186. Acesso em: 1 jul. 2017.

. O novo tempo do mundo. São Paulo: Boitempo, 2014 [ePub].

ARAÚJO, A.; AZEVEDO, J. F.; TENDLAU, M. (orgs.). Próximo ato: teatro de grupo. São Paulo: Itaú Cultural, 2011.

BAKHTIN, M. A cultura popular na Idade Média e no Renascimento. São Paulo: Hucitec, 2013.

BENJAMIN, W. Magia e técnica, arte e politica: ensaios sobre literatura e história da cultura. 8. ed. rev. São Paulo: Brasiliense, 2012. (Obras Escolhidas, v. 1).

BOAL, A. Técnicas latino-americanas de teatro popular: uma revolução copernicana ao contrário. São Paulo, Hucitec, 1979. 
.Hamlet e o filho do padeiro: memórias imaginadas. Rio de Janeiro: Record, 2000 .

Que pensa você da arte de esquerda? Disponível em: $\overline{<\mathrm{https}}$ //institutoaugustoboal.org/2012/11/24/que-pensa-voce-da-arte-de-esquerdaaugusto-boal/>

BOLOGNESI, M. F. Palhaços. São Paulo: Editora Unesp, 2003.

BORNHEIM, G. B. A estética do teatro. Rio de Janeiro: Graal, 1992.

BRACHER, B. Azul e dura. São Paulo: 7 Letras, 2002.

BRAVA COMPANHIA. Caderno de Erros II. São Paulo: Cooperativa Paulista de Teatro, 2011.

. Caderno de Erros III. São Paulo: Cooperativa Paulista de Teatro, 2014. . Caderno de Erros IV. São Paulo: LiberArs, 2015.

BRECHT, B. Teatro dialético. Rio de Janeiro: Civilização Brasileira, 1967. . A compra do latão (1939-1955). Lisboa: Vega, 1999. . Estudos sobre Teatro. Rio de Janeiro: Nova Fronteira, 2005.

BUARQUE, C. Estorvo. São Paulo: Companhia das Letras, 1991.

BUCCI, E.; KEHL, M. R. Videologias: Ensaios sobre televisão. São Paulo: Boitempo, 2004.

BURGUER, P. Teoria da vanguarda. São Paulo: Cosac Naify, 2012.

CALDAS, A. C. Centro Popular de Cultura no Paraná (1959-1964): encontros e desencontros entre arte, educação e política. Disponível em : http://ebookbrowse.com/search/ana-carolina-caldas-disserta $\% \mathrm{C} 3 \% 87 \% \mathrm{C} 3 \% 83 \mathrm{o}$

CANDIDO, Antonio. Formação da literatura brasileira: momentos decisivos. 7. ed. Belo Horizonte: Itatiaia, 1993, 2 v.

. A educação pela noite \& outros ensaios. São Paulo: Ática, 1987.

. Vários escritos. 3. ed. ampl. São Paulo: Duas Cidades, 1995.

. A ação do Teatro União e Olho Vivo. In: VIEIRA, C. Em busca de um teatro popular. 4. ed. São Paulo: Funarte, 2007.

Dialética da malandragem. In: $O$ discurso e a cidade. Rio de Janeiro: Ouro Sobre Azul, 2010 
CARBONE, R. O trabalho crítico de João das Neves no jornal Novos Rumos em 1960: perspectivas sobre a construção de um fazer teatral épico-dialético no Brasil. Dissertação de Mestrado. Escola de Comunicação e Artes, Universidade de São Paulo, São Paulo. 2014.

CARLETO, S. Teatro União e Olho Vivo: cultura tradicional e arte popular. Dissertação de Mestrado. Escola de Comunicação e Artes, Universidade Estadual Paulista, São Paulo. 2009.

CARVAlHO, D.; COSTA, I. C. A luta dos grupos teatrais de São Paulo por políticas públicas para a cultura. São Paulo: Cooperativa Paulista de Teatro, 2008.

CARVALHO, S. (Org.). Introdução ao teatro dialético: experimentos da Companhia do Latão. São Paulo: Expressão Popular, 2009.

. (Org.). O teatro e a cidade: lições de história do teatro. São Paulo: SMC, 2004.

Expressão

(Org.). Atuação crítica: entrevistas da Vintém e outras conversas. São Paulo:

CHAUIÍ, M. O nacional popular na cultura brasileira: seminários. São Paulo: Brasiliense, 1984.

COSTA, I. C. A hora do teatro épico no Brasil. São Paulo: Paz e Terra, 1996.

. Sinta o drama. Petrópolis: Vozes, 1998.

O teatro de grupo e alguns antepassados, In: ARAÚJO, A.; PEIXOTO, J.;

TENDLAU, M. Próximo ato: teatro de grupo. São Paulo: Itaú cultural, 2011.

. Nem uma lágrima. São Paulo: Expressão Popular; Nankin Editorial, 2012.

COSTA, I. C.; ESTEVAM, D.; VILLAS BOAS, R. Agitprop: cultura politica. São Paulo: Expressão Popular, 2016.

CRAIG, E. G. Da arte do teatro. Lisboa: Arcádia, 1963.

CRUZ, A. S. Narrativas contemporâneas da violência: Fernando Bonassi, Paulo Lins e Ferréz. Rio de Janeiro: 7 Letras, 2012.

D'ANDREA, Tiarajú. A formação dos sujeitos periféricos: cultura e política na periferia de São Paulo. Tese de Doutorado. Universidade de São Paulo, São Paulo. 2013 .

DEBORD, Guy. A sociedade do espetáculo. Rio de Janeiro: Contraponto, 1997. 
DESGRANGES, F.; LEPIQUE, M. (Orgs.). Teatro e vida pública: o fomento e os coletivos teatrais de São Paulo. São Paulo: Hucitec, 2012.

ESTEVAM, C. A questão da cultura popular. Rio de Janeiro: Tempo Brasileiro, 1963. (Coleção Brasil Hoje, v.2).

EAGLETON, Terry. Marxismo e crítica literária. São Paulo: Editora Unesp, 2011. FARIA, J. R. (Dir.). História do teatro brasileiro II: do modernismo às tendências contemporâneas. São Paulo: Editora Perspectiva; SESC/SP, 2013.

FARIA, A.; PENNA, J. C.; TONANI, P. R. Modos da margem: figurações da marginalidade na literatura brasileira. Rio de Janeiro: Aeroplano, 2015.

FERREIRA, J. (Org.). O populismo e sua história: debate e crítica. Rio de Janeiro: Civilização Brasileira, 2001.

FERRÉZ. Capão pecado. São Paulo: Labortexto, 2000.

FORJAZ, C. À luz da linguagem: a iluminação cênica: de instrumento da visibilidade à "scriptura" do visível \& outras poéticas da luz. Tese de Doutorado. Escola de Comunicação e Artes, Universidade de São Paulo, São Paulo. 2013.

FREDERICO, C. Da periferia ao centro: cultura e política em tempos pós-modernos. Estudos avançados, São Paulo, v. 27, n. 79, p. 239- 255, 2013.

GALERA, D. Até o dia em que o cão morreu. São Paulo: Companhia das Letras, 2007.

GARCIA, S. O teatro da militância. São Paulo: Editora Perspectiva,1990.

GARCIA, W. Ouvindo Racionais MC's. Teresa: Revista de Literatura Brasileira, São Paulo, n. 4-5, p. 166-180, 2004.

. 'Diário de um detento': uma interpretação. In: NESTROVSKI, A. (Org). Lendo música. São Paulo: Publifolha, 2007.

Sobre uma cena de 'Fim de semana no Parque', do Racionais MC's. Estudos avançados, São Paulo, v. 25, n. 71, abr. 2011.

. Elementos para a crítica da estética do Racionais MC's (1990-2006). Ideias, Campinas, n. 7, p. 81-110, 2013.

HOLANDA, S. B. Raízes do Brasil. 20. ed. Rio de Janeiro: José Olympio, 1988.

JAMESON, F. O método Brecht. Petrópolis: Vozes, 1999. 
Pós - modernismo: a lógica cultural do capitalismo tardio. São Paulo: Ática,

GRUPO KRISIS. Manifesto contra o trabalho. São Paulo: Conrad, 2003.

GUINSBURG, J. Stanislávski, Meierhold \& Cia. São Paulo: Perspectiva., 2001.

KANDINSKY, N. Do espiritual na arte. São Paulo: Martins Fontes, 1990.

KEHL, M. R. A preguiça na cadência do samba. In: NOVAES, A. (Org.). Mutações: elogio à preguiça. São Paulo: Edições SESC SP, 2012.

. Sala de recepção. In: NESTROVSKY, A. Lendo música. São Paulo: Publifolha, 2007.

KINAS, F. A lei e o programa de Fomento ao teatro para a cidade de São Paulo. Uma experiência de política pública bem-sucedida. 3. Simpósio Internacional de Cultura e Comunicação na America Latina. Extraprensa. Edição especial, p. 194-203.

KOUDELA, I. Brecht: um jogo de aprendizagem. São Paulo: Perspectiva; Edusp, 1991.

KUCINSKI, B. K. Relato de uma busca. São Paulo: Cosac Naify, 2014.

LINS, P. Cidade de Deus. São Paulo: Companhia das Letras, 2002.

LOWI, M. Walter Benjamin: aviso de incêndio: uma leitura das teses "Sobre o conceito de história". São Paulo: Boitempo, 2005.

MATE, A. L. A produção teatral paulistana dos anos 1980: r(ab)iscando com faca o chão da história: tempo de contar os (pré) juízos em percurso de andança. Tese de Doutorado. Faculdade de Filosofia, Letras e Ciências Humanas, Universidade de São Paulo, São Paulo. 2008.

MIORIM, M. Arte para educar os sentidos: a atuação da Brava Companhia no Parque Santo Antonio-SP. Dissertação de Mestrado. Universidade Estadual de Campinas, São Paulo. 2012.

MOTA, C. G. Ideologia da cultura brasileira (1933-1974). 4.ed. São Paulo: Ática, 1978.

MORAES, R. Tanto faz \& Abacaxi. São Paulo: Companhia das Letras, 2011.

Pornopopeia. São Paulo: Objetiva, 2009. 
NAPOLITANO, M. A arte engajada e seus públicos (1955-1968): estudos históricos. Rio de Janeiro: Fundação Getúlio Vargas, 2001.

. No exílio, contra o isolamento: intelectuais comunistas, frentismo e questão democrática nos anos 70. Estudos avançados, São Paulo, v. 28, n. 80, p. 41-58, 2014.

Coração civil: Arte, resistência e lutas culturais durante o regime militar brasileiro (1964-1980). Tese (Livre-docência em História). Faculdade de Filosofia, Letras e Ciências Humanas, Universidade de São Paulo. 2011.

NASCIMENTO, A. Teatro experimental do negro: trajetória e reflexões. Estudos Avançados, v. 18, n. 50, 2004.

OLIVEIRA, A. O fim da canção? Racionais MC's como efeito colateral do sistema cancional brasileiro. Tese de Doutorado. Faculdade de Filosofia, Letras e Ciências Humanas, Universidade de São Paulo, São Paulo, 2015.

OLIVEIRA, F. Crítica da razão dualista / O ornitorrinco. São Paulo: Boitempo, 2003.

ORTIZ, R. Cultura brasileira e identidade nacional. São Paulo: Brasiliense, 2006.

OTSUKA, E. T. Espírito rixoso: para uma reinterpretação das Memórias de um sargento de milícias. Revista IEB, São Paulo, n. 44, p. , ano?.

PAIXAO, C. D. A. Política e cultura na década de 1970: o trabalho do Grupo de Teatro Forja e do Teatro Popular União e Olho Vivo. Dissertação de Mestrado. Universidade Estadual Paulista, São Paulo. 2009.

PASTA, J. A. O Trabalho de Brecht. São Paulo: Duas Cidades; Editora 34, 2010.

O romance de Rosa: temas do Grande Sertão e do Brasil. Novos Estudos, São Paulo, n. 55, p. ?, ano?

PASTORELLI, V. M. Da irresistível peleja entre piratas e tubarões: um estudo sobre a parceria Brecht/Weill. Dissertação (Mestrado em Teoria Literária e Literatura Comparada). Faculdade de Filosofia, Letras e Ciências Humanas, Universidade de São Paulo, 2014.

PATROCÍNIO, P. R. T. Escritos à margem: a presença de autores de periferia na cena literária brasileira. Rio de Janeiro: 7 Letras; Faperj, 2013.

PAVIS, P. A análise dos espetáculos. São Paulo: Perspectiva, 2008.

PEIXOTO, F. Brecht, uma introdução ao teatro dialético. Rio de Janeiro: Paz e Terra, 1981. 
. Teatro em movimento. São Paulo: Hucitec, 1989.

.(Org). Um teatro fora do eixo. 2. ed. São Paulo: Editora Hucitec, 1997.

. (Org.). Vianinha. Teatro. Televisão. Política. São Paulo: Brasiliense, 1999.

PERCASSI, J. Arte, política, educação popular: diálogos necessários para a transformação social. Tese (Doutorado em Educação). Faculdade de Educação, Universidade de São Paulo, 2014.

PIACENTINI, N. Para melhorar a vida das pessoas, In: DESGRANGES, F.; LEPIQUE, M. (Org.). Teatro e vida pública: o fomento e os coletivos teatrais de São Paulo. São Paulo: Hucitec, 2012.

PISCATOR, E. Teatro político. Rio de Janeiro: Civilização Brasileira, 1968.

POZZOLI, M. S. (Org.). Coleção cadernos de pesquisa: Teatro União e Olho Vivo. São Paulo: Centro Cultural São Paulo, 2008.

PRADO JR., C. Formação do Brasil contemporâneo: colônia. 23. ed. São Paulo: Brasiliense, 1994.

ROSA, G. Primeiras estórias. Rio de Janeiro: Nova Fronteira, 2001.

ROCHA, J. C. de C. Dialética da marginalidade: caracterização da cultura brasileira contemporânea. Folha de São Paulo, São Paulo, 29 fev. 2004. Disponível em: http://www1.folha.uol.com.br/fsp/mais/fs2902200404.htm. Acesso em: 1 jul. 2017.

ROSENFELD, A. O mito e o herói no moderno teatro brasileiro. 2. ed. São Paulo: Perspectiva, 1996a.

. Texto/Contexto I. São Paulo: Perspectiva, $1996 \mathrm{~b}$.

. Teatro moderno. São Paulo, Perspectiva, 1997.

. Prismas do teatro. São Paulo, Perspectiva, 2000.

. O teatro épico. São Paulo, Perspectiva, 2002.

. Brecht e o teatro épico.São Paulo, Perspectiva, 2012.

ROUBINE, J. J. A linguagem da encenação teatral (1880-1980). Rio de Janeiro: Zahar, 1996. 
SADER, Eder. Quando novos personagens entraram em cena: experiência e lutas dos trabalhadores da grande São Paulo (1970-1980). Rio de Janeiro: Paz e Terra, 1988.

SADER, Emir. Golpe atualizou e fortaleceu a contraposição entre direita e esquerda. Jornal do Totonho. 29 mai. 2017. Disponível em: http://www.jornaldototonho.com.br/golpe-atualizou-e-fortaleceu-a-contraposicao-entredireita-e-esquerda-emir-sader/. Acesso em: 1 jul. 2017.

SCHWARZ, R. Cultura e política (1964-1969). In: O Pai de Família e outros estudos. São Paulo: Companhia das Letras, 2008.

. Nacional por subtração. In: Que horas são? São Paulo: Cia. das Letras, 1987.

. Sequências brasileiras. São Paulo: Companhia das Letras, 1999.

- Ao vencedor as batatas: forma literária e processo social nos inícios do romance brasileiro. 2. ed. São Paulo: Duas Cidades, 1981.

SITUACIONISTA. Teoria e prática da revolução/Internacional Situacionista. São Paulo: Conrad, 2002.

SZONDI, Peter. Teoria do drama moderno. São Paulo: Cosac \& Naify, 2001.

TATIT, L. Dicção de Noel Rosa. In: O cancionista. São Paulo: Edusp, 2002.

TOMMASI, L. Culturas de periferia: entre o mercado, os dispositivos de gestão e o agir político. Política \& Sociedade, Florianópolis, v. 12, n. 23, p. 11-34, 2013.

TORRES. A. Teatro União e Olho Vivo: uma pista para uma outra cena brasileira em São Paulo. Dissertação de Mestrado. Escola de Comunicação e Artes, Universidade de São Paulo, São Paulo. 1989.

URBINATTI, T. Peões em cena. São Paulo: Hucitec, 2011.

WILLIAMS, R. Base e superestrutura - Revista USP, São Paulo, n. 65, p. 210-24, 2005.

VIANNA, H. O mistério do samba. Rio de Janeiro: Zahar e UFRJ Editora, 2008.

. C-i-d-a-d-e-d-e-D-e-u-s. In: NESTROVSKI, A. (Org). Lendo música. São Paulo: Publifolha, 2007.

VIANA, S. Rituais de sofrimento. São Paulo: Boitempo, 2013.

VIANNA FILHO, O. Moço em estado de sítio. Cópia da Biblioteca Lasar Segall, 1965. 
. Teatro, televisão e política. 2. ed. São Paulo: Brasiliense, 1983

VIEIRA, C. Em busca de um teatro popular. 4. ed. São Paulo: Funarte, 2007. . Coleção TUOV 40 anos. Guarulhos: Secretaria de Cultura de Guarulhos, 2008. . Corinthians, meu amor, 1966.

WISNIK, J. M. O famigerado. Scripta, Belo Horizonte, v. 5, n. 10, p. 177-198, 2002.

\section{Filmes e vídeos}

A MEMÓRIA que me contam. Direção: Lúcia Murat. Brasil/Argentina, 2012.

CIDADE de Deus. Direção: Fernando Meirelles e Kátia Lund. Produção: Donald Ranvaud e Walter Salles. Brasil/França/EUA, 2002.

CONVERSAS Folianescas. Entrevistas [DVD]. Direção: Zeca Rodrigues. Distribuição: Grupo Folias d' Arte. 2007.

CRONICAMENTE inviável. Direção: Sergio Bianchi. Brasil, 2000.

DEMOCRACIA em preto e branco. Direção: Pedro Asbeg. Brasil, 2014.

HOJE. Direção: Tata Amaral. Brasil, 2013.

LINHA de montagem. Direção: Renato Tapajós. Brasil, 1982.

O INVASOR. Direção: Beto Brant. Produção: Renato Ciasca. Brasil, 2002.

O SOM ao redor. Direção:Kleber Mendonça Filho. Brasil, 2013.

OS INQUILINOS. Direção: Sergio Bianchi. Brasil, 2009.

PEÕES. Direção: Eduardo Coutinho. Brasil. 2004.

QUANTO vale ou é por quilo? Direção: Sergio Bianchi. Brasil, 2005.

REGISTRO do espetáculo Corinthians, Meu Amor - Segundo a Brava Companhia Uma homenagem ao Teatro União e Olho Vivo. Site YouTube. 


\title{
Anexos
}

\section{Anexo A - Ficha técnica: Corinthians, Meu amor - a Revolução Alvi-Negra}

\author{
Teatro Casarão
}

Texto original: Cesar Vieira

Texto adaptado: Cesar Vieira

Direção: Waldemar Silas

Músicas: Laura Tetti

Elenco de estréia:

Arthur

Douglas Franco

Didi

Eduardo

Fábio

João Carlos Botezelli

Lígia de Paula

Marcelino Buru Moreira

Milton

Neriney Moreira

Reinaldo Mestrinel

Romeu

Sergio Pimentel

Therezinha

Vicente Viscaíno

Walter Rocha ${ }^{37}$

${ }^{37}$ O elenco acima mencionado está documentado no livro Em busca de um teatro popular (VIEIRA, 2007, p. 89). 
Anexo B - Ficha técnica: Corinthians, meu amor. Segundo Brava Companhia Uma homenagem ao teatro popular União e Olho Vivo

Brava Companhia

Texto Original: Cesar Vieira

Texto adaptado: Fabio Resende

Direção: Rafaela Carneiro

Direção Musical: Luciano Carvalho

Músicas: Brava Companhia

Luciano Carvalho

Juh Vieira

Cesar Vieira

Laura Maria

Produção: Kátia Alves

Elenco de estréia:

Ademir de Almeida

Cris Lima

Débora Torres

Henrique Alonso

Joel Carozzi

Luciana Gabriel

Marcio Rodrigues

Max Raimundo

Sergio Carozzi

Cenários, adereços e figurinos:

Joel Carozzi

Marcio Rodrigues

Sergio Carozzi 


\author{
Iluminação: \\ Débora Torres \\ Henrique Alonso \\ Fabio Resende ${ }^{38}$
}

\title{
Atuação nos vídeos:
}

Alessandra Queiroz

Alexandre Krug

Arthur Alves E. Sotero de Almeida

Beto Nunes

Brava Companhia

Cristiana Fabrício

Daniela Rodrigues Leite

Danilo Minhano

Eloiza Alves

Erika Coracini

Flavio Pires

Franklin Jones

Gabriel Silva

Haroldo Docario

Iraci Tomiatu

Ilka Arão

Juh Vieira

Luiz Calvo

Marcos Pavanelli

Mariana Martins Fontes

Mariana Senne

Martin Gifford Tarifa

Natalia Siufi

Osvaldo Pinheiro

${ }^{38} \mathrm{O}$ elenco acima mencionado está documentado no Caderno de Erros II (BRAVA COMPANHIA, 2001, p. 265). A atuação nos vídeos (a seguir) é realizada por integrantes de grupos parceiros e artistas da cidade de São Paulo e está incompleta, mesmo no documento original. 


\author{
Patrícia Gifford \\ Rafael Graciola \\ Rogério Tarifa \\ Rosangela Laranjeira \\ Ruth Melchior \\ Simone Brites Pavanelli \\ Simone Gordon \\ Vanessa Viotti \\ Veni Toledo \\ Vera Lamy \\ Zernesto Pessoa
}

